\title{
PENGAUDITAN INTERNAL
}

Drs. Nurasik, MM

Santi Rahma Dewi, M.Ak

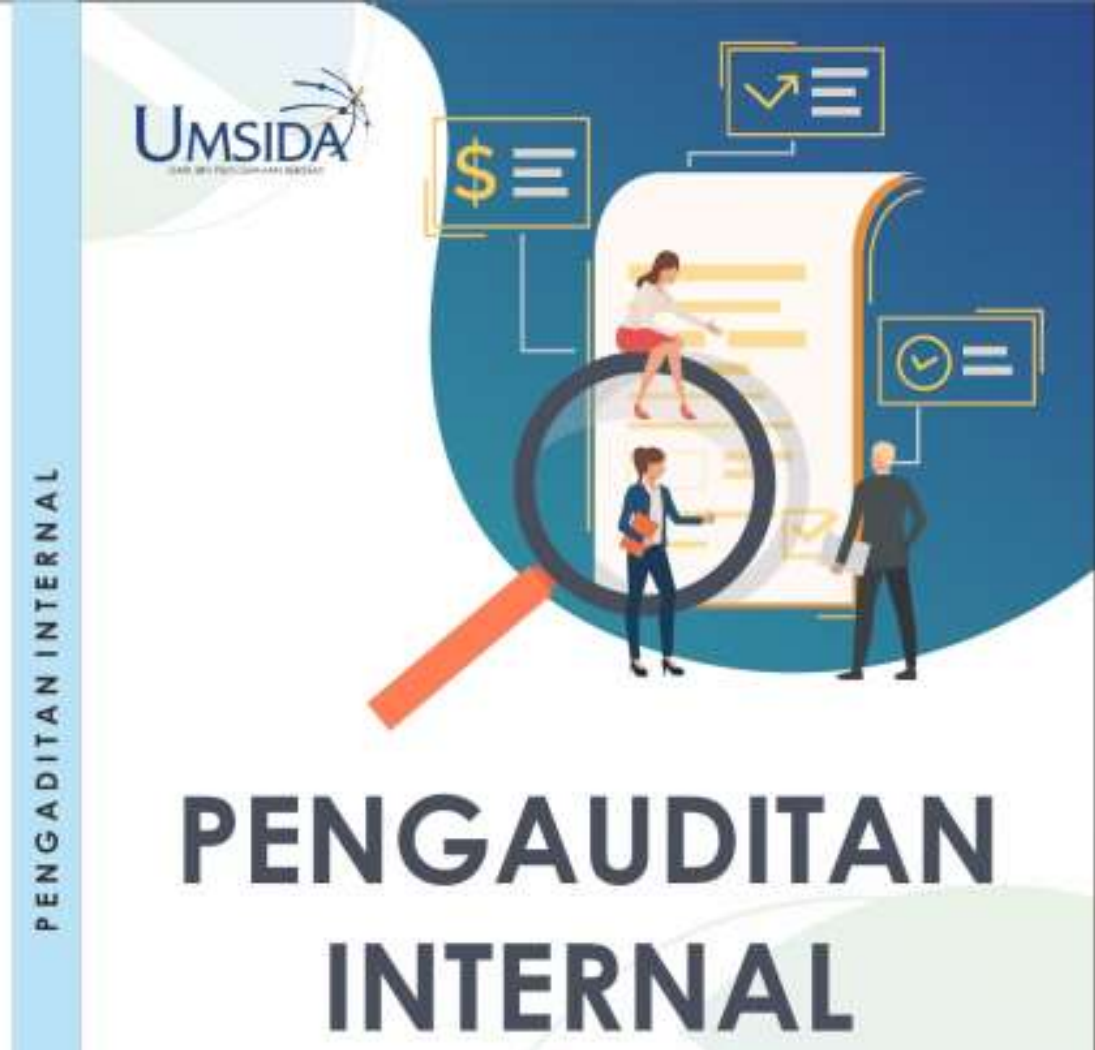

Drs. Nurasik, MM Santi Rahma Dewi, M.Ak 


\section{BUKU AJAR}

\section{PENGAUDITAN INTERNAL}

\section{Penulis:}

Drs.Nurasik, M.M.

Santi Rahma Dewi, SE., M.Ak

\section{ISBN :}

978-623-6833-56-8

\section{Editor:}

Dr. Sigit Hermawan, SE., M.Si

\section{Design Sampul dan Tata Letak:}

Mochammad Nasrulloh, S.Pd.

Amy Yoga Prajati, S.Kom.

Penerbit:

UMSIDA Press

Anggota IKAPI No. 218/Anggota Luar Biasa/JTI/2019

Anggota APPTI No. 0020181092017

Redaksi

Universitas Muhammadiyah Sidoarjo

Jl. Mojopahit No 666B

Sidoarjo, Jawa Timur

Cetakan Pertama, September 2020

CHak Cipta dilindungi undang undang

Dilarang memperbanyak karya tulis ini dengan sengaja, tanpa ijin tertulis dari penerbit. 


\section{KATA PENGANTAR}

Puji syukur kami panjatkan kehadirat Allah SWT, atas rahmat dan karunia-Nya Buku Ajar Pengauditan Internal dapat diselesaikan dengan baik dan tanpa halangan yang berarti. Shalawat dan salam selalu kami sampaikan kepada junjungan Nabi Muhammad SAW.

Tim penulis mengucapkan terimakasih kepada:

1. Wisnu Panggah, Phd., Dekan Fakultas Ekonomi Bisnis, Sosial Politik dan Hukum yang memberikan arahan dan motivasi kepada penulis dalam menyelesaikan buku ajar ini.

2. Wiwit Haryanto, SE.,M.Si Kaprodi Akuntansi yang telah memberikan dukungan untuk menyusun buku ajar ini.

3. Rekan-rekan dosen pengampu Mata Kuliah Pengauditan Internal di prodi akuntansi yang telah berbagi pengalaman dalam mengampu mata kuliah tersebut.

Saran dan kritik sangat penulis harapkan untuk mewujudkan buku ajar Berpikir Analisis melalui Fluida yang lebih baik dan tentunya sesuai dengan amanat peraturan yang berlaku. Terimakasih.

Tim Penulis 


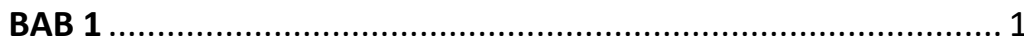

SIGNIFIKANSI AUDIT INTERNAL DI PERUSAHAAN SAAT INI ........ 4

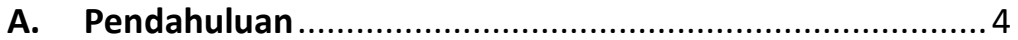

B. Latar Belakang Audit Internal ..................................... 7

C. Piagam Auditor Internal. .............................................. 9

D. Struktur Bidang Audit Internal ................................... 14

E. Contoh Kasus Audit Internal Aset Tetap ...................... 22

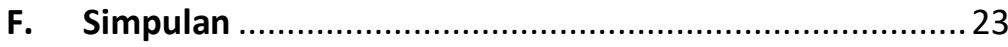

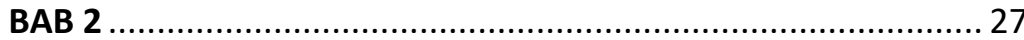

PENGETAHUAN UMUM AUDITOR INTERNAL ............................ 27

A. Pendahuluan ....................................................... 27

B. Standar Internasional Untuk Praktek Profesional Auditing

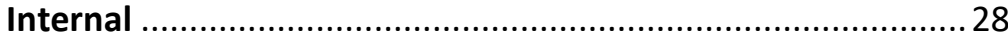

C. Pengetahuan Umum \& Praktek Manajemen .................. 38

D. Persyaratan CBOK: Pentingnya Pengendalian Internal .... 38

E. Persyaratan CBOK: Merencanakan dan Melakukan Audit Internal ............................................................................. 40

F. Persyaratan СВОK: Mengorganisasi dan Mengelola Aktivitas Audit Internal ...................................................... 41

G. Persyaratan CBOK: Dampak Teknologi Informasi pada Audit Internal................................................................... 43

H. Persyaratan CBOK: Audit Internal dan Tata Kelola Bisnis 44 I. Simpulan .................................................................... 45

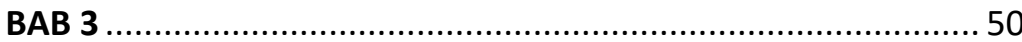

KERANGKA PENGENDALIAN INTERNAL COSO ........................ 50 
B. Kerangka Kerja COSO dan Perubahan Lingkungan...........55

C. Kerangka Kerja Pengendalian COSO ..............................5 57

D. Prinsip Pengendalian Internal COSO ..............................59

E. Komponen Pengendalian Internal COSO : Lingkungan Pengendalian ..................................................................... 60

F. Komponen Pengendalian Internal COSO: Menilai Risiko. 64

G. Komponen Pengendalian Internal Coso: Aktivitas

Pengendalian Internal.

H. Komponen Pengendalian Internal: Informasi dan Kommunikasi

I. Komponen Pengendalian Internal COSO: Aktivitas Pemantauan. .79

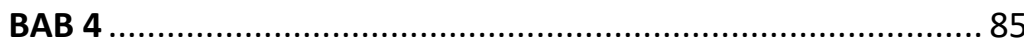

PRINSIP PENGENDALIAN INTERNAL COSO ........................... 85

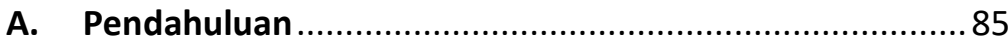

B. Prinsip Pengendalian Internal COSO ............................ 87

C. Prinsip Lingkungan Pengendalian 1: Integritas dan NilaiNilai Etis 89

D. Prinsip Lingkungan Pengendalian 2: Peran Direksi .92

E. Prinsip Lingkungan Pengendalian 3: Kebutuhan Otoritas dan Tanggungjawab................................................... 94

F. Prinsip Lingkungan Pengendalian 4: Komitmen Kepada Pekerja yang Kompeten. 95

G. Prinsip Pengendalian Lingkungan 5: Memegang Orangorang Accountable .96

H. Prinsip Penilaian Risiko 6: Menentukan Tujuan Penilaian Risiko Yang Tepat. 
I. Prinsip Penilaian Risiko 7: Mengidentifikasi dan Menganalisis Risiko .98

J. Prinsip Penilaian Risiko 8: Penilaian Risiko Kecurangan .. 99

K. Prinsip Penilaian Risiko 9: Mengidentifikasi Perubahan yang Mempengaruhi Pengendalian Intern

L. Prinsip Aktivitas Pengendalian 10: Memilih Aktivitas

Pengendalian yang Mengatasi Risiko 103

M. Prinsip Aktivitas Pengendalian 11: Memilih dan Mengembangkan Pengendalian Teknologi 105

N. Prinsip Aktivitas Pengendalian 12: Kebijakan dan Prosedur 105

O. Prinsip Informasi dan Komunikasi 13: Menggunakan Informasi yang Relevan dan Berkualitas 106

P. Prinsip Informasi dan Komunikasi 14: Komunikasi Internal 109

Q. Prinsip Informasi dan Kommunicasi 15: Komunikasi

Eksternal

R. Prinsip Pemantauan 16: Evaluasi Pengendalian Internal 114

S. Prinsip Pemantauan 17: Mengkomunikasikan Defisiensi Pengendalian Internal

T. Simpulan ................................................................. 116

U. Contoh Kasus ........................................................ 117

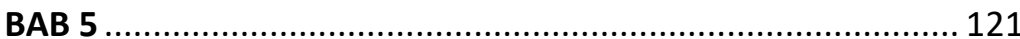

MENGELOLA RISIKO BISNIS: COSO ERM ............................. 121

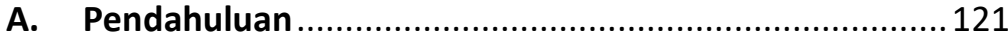

B. COSO ERM: Pengelolaan Risiko Bisnis ....................... 122 
C. Elemen COSO ERM Utama ........................................ 124

D. Dimensi Lain dari COSO ERM: Tujuan Risiko Bisnis........ 135

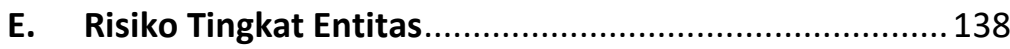

F. Risiko Audit dan Proses ERM ................................... 139

G. Contoh Kasus ....................................................... 142

H. Simpulan ........................................................... 141

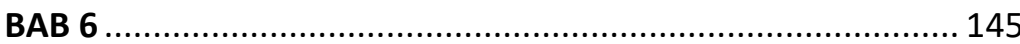

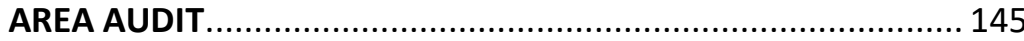

MEMBENTUK AUDIT UNIVERSE DAN PROGRAM AUDIT ......... 145

A. Pendahuluan .............................................................. 145

B. Menilai Kapabilitas dan Tujuan Audit Internal ............. 146

C. Keterbatasan Waktu dan Sumber Daya Dalam Audit

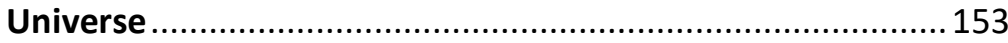

D. Menyusun Program Audit: Komponen Kunci Audit

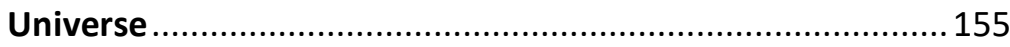

E. Contoh Kasus Area Audit ........................................... 162

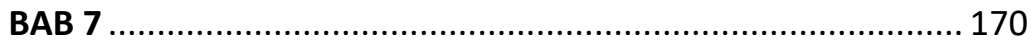

MEMBANGUN FUNGSI AUDIT INTERNAL ............................. 170

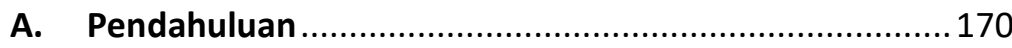

B. Piagam Audit Internal ................................................. 171

C. Fungsi Audit Internal .............................................. 172

D. Peran Audit Internal Masa Kini..................................... 178

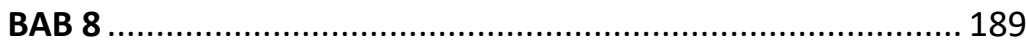

MENGUJI, MENILAI, DAN MENGEVALUASI BUKTI AUDIT........ 189

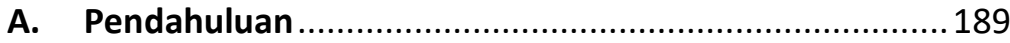

B. Bukti Audit .............................................................. 190 
C. Teknik Penilaian dan Evaluasi Bukti Audit 192

D. Mengembangkan Rencana Sampling Statistik 196

E. Pendekatan Sampling Audit ...................................... 200

F. Prosedur Pengambilan Sampel Atribut .......................202

G. Melakukan Tes Pengambilan Sampel Atribut ............... 203

H. Memilih Sampel untuk Melakukan Prosedur Audit....... 206

I. Mengevaluasi Hasil Uji Sampling Atribut .................... 206

J. Contoh Sampel Attribut Audit ............ Error! Bookmark not defined.

K. Keunggulan dan Kelemahan Sampel Atribut ................ 208

L. Sampling Unit Moneter .......................................... 209

M. Membuat Sampling Audit Yang Efisien dan Efektif....217

N. Contoh Kasus Mennguji, Menilai dan Mengevaluasi Bukti Audit. 221

O. Simpulan ............................ Error! Bookmark not defined.

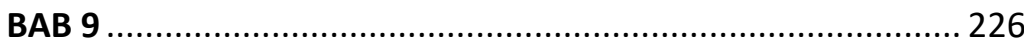

KOMPETENSI UTAMA AUDITOR INTERNAL ........................... 226

A. Pendahuluan ............................................................. 226

B. Mengelola Audit Internal Universe ........................... 227

C. Jadwal Audit Universe .................................................. 230

D. Kompetensi Kunci Auditor Internal .............................. 233

E. Manajemen Risiko .................................................... 231

F. Keterampilan Wawancara ......................................... 234

G. Keterampilan Analisis dan Pengujian ......................... 234

H. Keterampilan Komunikasi ........................................ 236 
I. Keterampilan Dokumentasi

J. Hasil yang Direkomendasikan dan Tindakan Korektif....238

K. Keterampilan Negosiasi 239

L. Komitmen Auditor Internal Untuk Belajar ................... 240

M. Contoh Kasus mengelola audit internal universe dan kompetensi utama. 240

BAB 10 MERENCANAKAN AUDIT ......................................... 245

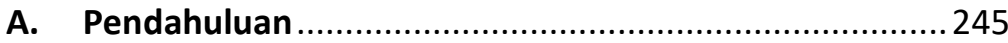

B. Perencanaan Audit Internal......................................... 245

C. Memahami Lingkungan Bisnis ................................... 249

D. Memahami Lingkungan Pengendalian Internal ............ 254

E. Contoh Kasus Perencanaan Audit ...............................262

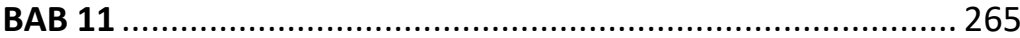

PELAKSANAAN AUDIT INTERNAL........................................ 265

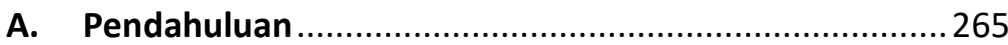

B. Mengorganisasi dan Merencanakan Audit Internal....... 267

C. Aktivitas Persiapan Audit Internal..............................270

D. Memulai Audit Internal ........................................... 276

E. Mengembangkan Program Audit ...............................2282

F. Melaksanakan Audit Internal .................................... 286

G. Pemantauan Kerja Lapangan ...................................... 287

H. Menyelesaikan Pekerjaan Lapangan ............................ 292

I. Malaksanakan Audit Internal Individu ......................... 293

BAB 12 LAPORAN HASIL AUDIT INTERNAL............................. 299

A. Pendahuluan .......................................................... 299 
B. Tujuan dan Jenis Laporan Hasil Audit Internal ...............300

C. Laporan Hasil Audit yang Diterbitkan .......................... 302

D. Siklus Pelaporan Hasil Audit Internal ........................... 313

E. Contoh Kasus Laporan Hasil Audit.............................. 315

F. Simpulan ........................... Error! Bookmark not defined.

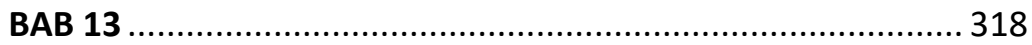

PROGRAM ETIKA DAN WHISTLEBLOWER ............................. 318

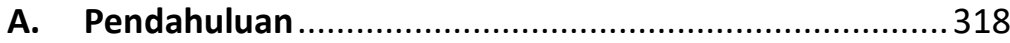

B. Etika, Kepatuhan, dan Tata Kelola Perusahaan ............. 319

C. Langkah Pertama Membangun Etika: Mengembangkan

Pernyataan Misi.................................................................. 320

D. Memahami Lingkungan Risiko Etika........................... 321

E. Meringkas Hasil Survei Etika....................................... 324

F. Kode Etik Perilaku Bisnis............................................ 325

G. Fungsi Whistleblower dan Hotline ............................ 330

H. Mengaudit Fungsi Etika Perusahaan ............................ 333

I. Meningkatkan Program Tata Kelola Perusahaan ........... 335

J. Contoh Kasus Mengaudit Fungsi Etika Perusahaan ....... 336

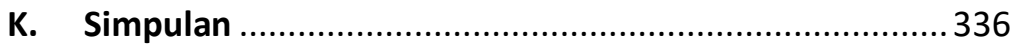

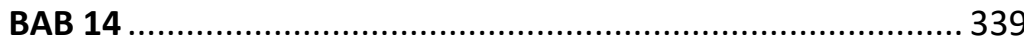

INTERNAL AUDIT DAN PENCEGAHAN FRAUD ......................... 339

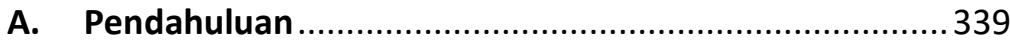

B. Memahami Kecurangan........................................... 342

C. Red Flags: Sinyal untuk Mendetaksi Kecurangan........... 343

D. Standar IIA Untuk Mendeteksi dan Investigasi Kecurangan 347 
E. Investigasi Kecurangan Oleh Auditor Internal .............. 353

F. Proses Pencegahan Penipuan Teknologi Informasi........ 354

G. Deteksi Fraud Auditor Internal ................................. 358

H. Contoh Kasus Deteksi Fraud Auditor Internal ................ 359

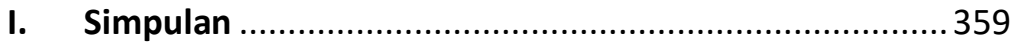




\section{BATANG TUBUH DAN}

\section{SUB-CAPAIAN PEMBELAJARAN MATA KULIAH}

\begin{tabular}{|c|c|}
\hline BAB & Sub-Capaian Pembelajaran Mata Kuliah \\
\hline $\begin{array}{l}\text { BAB I } \\
\text { PERKEMBANG } \\
\text { AN AUDIT } \\
\text { MANAJEMEN }\end{array}$ & $\begin{array}{l}\text { 1. Mahasiswa mampu memahami Latar Belakang dan } \\
\text { sejarah Internal Audit } \\
\text { 2. Mahasiswa mampu memahami Misi Audit } \\
\text { Manajemen } \\
\text { 3. Mahasiswa mampu memahami Audit manajemen } \\
\text { Berbasis Resiko }\end{array}$ \\
\hline $\begin{array}{l}\text { BAB II } \\
\text { KERANGKA } \\
\text { PENGENDALIA } \\
\text { N INTERNAL } \\
\text { COSO }\end{array}$ & $\begin{array}{l}\text { 1. Mahasiswa mampu memahami Prinsip } \\
\text { Pengendallian Internal coso } \\
\text { 2. Mahasiswa mampu mengidentifikasi Pengendalian } \\
\text { Lingkungan } \\
\text { 3. Mahasiswa mampu melakukan Penilaian Risiko } \\
\text { 4. Mahasiswa mampu mengidentifikasi Pengendalian } \\
\text { Internal Kegiatan } \\
\text { 5. Mahasiswa mampu mengaplikasikan Informasi dan } \\
\text { Komunikasi } \\
\text { 6. Mahasiswa mampu mengidentifikasi Kegiatan } \\
\text { Pemantauan }\end{array}$ \\
\hline $\begin{array}{l}\text { BAB III } \\
\text { MANAJEMEN } \\
\text { RISIKO } \\
\text { PERUSAHAAN: } \\
\text { COSO ERM }\end{array}$ & $\begin{array}{l}\text { 1. Mahasiswa mampu memahami Dasar-dasar } \\
\text { Manajemen Risiko } \\
\text { 2. Mahasiswa mampu memahami Manajemen Risiko } \\
\text { Perusahaan } \\
\text { 3. Mahasiswa mampu mengidentifikasi Elemen Kunci } \\
\text { COSO ERM } \\
\text { 4. Mahasiswa mampu memahami Dimensi Tujuan } \\
\text { identifikasi Risiko Perusahaan } \\
\text { 5. Mahasiswa mampu memahami Risiko Tingkat Entitas } \\
\text { 6. Mahasiswa mampu memahami risiko Audit dan } \\
\text { Proses ERM COSO }\end{array}$ \\
\hline $\begin{array}{l}\text { BAB IV } \\
\text { MELAKUKAN } \\
\text { AUDIT }\end{array}$ & $\begin{array}{l}\text { 1. Mahasiswa mampu memahami Perencanaani Audit } \\
\text { manajemen }\end{array}$ \\
\hline
\end{tabular}




\begin{tabular}{|c|c|}
\hline $\begin{array}{l}\text { MANAJEMEN } \\
\text { YANG EFEKTIF }\end{array}$ & $\begin{array}{l}\text { 2. Mahasiswa mampu memahami Pengorganisasian } \\
\text { dan Perencanaan Audit manajemen } \\
\text { 3. Mahasiswa mampu memahami kegiatan persiapan } \\
\text { audit manajemen } \\
\text { 4. Mahasiswa mampu memahami memulai audit } \\
\text { manajemen } \\
\text { 5. Mahasiswa mampu memahami mengembangkan } \\
\text { dan menyiapkan program audit } \\
\text { 6. Mahasiswa mampu melakukan audit manajemen } \\
\text { 7. Mahasiswa mampu mengakhiri audit manajemen } \\
\text { 8. Mahasiswa mampu melakukan audit manajemen } \\
\text { individual }\end{array}$ \\
\hline $\begin{array}{l}\text { BAB V } \\
\text { MENGUJI, } \\
\text { MENILAI, DAN } \\
\text { MENGEVALUA } \\
\text { SI BUKTI } \\
\text { AUDIT }\end{array}$ & $\begin{array}{l}\text { 1. Mahasiswa mampu mengumpulkan bukti audit yang } \\
\text { tepat } \\
\text { 2. Mahasiswa mampu memahami teknik penilaian dan } \\
\text { evaluasi audit } \\
\text { 3. Mahasiswa mampu memahami sampling penilaian } \\
\text { audit manajemen } \\
\text { 4. Mahasiswa mampu mengembangkan rencana } \\
\text { pengambilan sampel statistik } \\
\text { 5. Mahasiswa mampu memahami pendekatan sampel } \\
\text { audit }\end{array}$ \\
\hline $\begin{array}{l}\text { BAB VI } \\
\text { KOMPETENS } \\
\text { I UTAMA } \\
\text { AUDITOR }\end{array}$ & $\begin{array}{l}\text { 1. Mahasiswa mampu memahami pentingnya } \\
\text { kompetensi utama audit manajemen } \\
\text { 2. Mahasiswa mampu memahami pentingnya } \\
\text { manajemen risiko audit manajemen } \\
\text { 3. Mahasiswa mampu memahami keahlian wawancara } \\
\text { auditor internal } \\
\text { 4. Mahasiswa mampu memahami keahlian analisis dan } \\
\text { pengujian audit manajemen } \\
\text { 5. Mahasiswa mampu memahami keahlian } \\
\text { mendokumentasikan auditor internal } \\
\text { 6. Mahasiswa mampu memahami merekomendasikan } \\
\text { hasil dan tindakan korektif }\end{array}$ \\
\hline
\end{tabular}




\begin{tabular}{|c|c|}
\hline & $\begin{array}{l}\text { 7. Mahasiswa mampu memahami keterampilan } \\
\text { negosiasi auditor internal } \\
\text { 8. Mahasiswa mampu memahami komitmen auditor } \\
\text { internal untuk belajar }\end{array}$ \\
\hline $\begin{array}{l}\text { BAB VII } \\
\text { MERENCA } \\
\text { NAKAN } \\
\text { AUDIT }\end{array}$ & $\begin{array}{l}\text { 1. Mahasiswa mampu memahami merencanakan audit } \\
\text { manajemen } \\
\text { 2. Mahasiswa mampu memahami entitas yang diaudit } \\
\text { 3. Mahasiswa mampu mendokumentasikan dan } \\
\text { memahami lingkungan pengendalian Internal } \\
\text { 4. Mahasiswa mampu melakukan prosedur audit } \\
\text { manajemen yang tepat dan mengakhiri audit }\end{array}$ \\
\hline $\begin{array}{l}\text { BAB VIII } \\
\text { PROGRAM } \\
\text { ETIKA DAN } \\
\text { WHISTLEBL } \\
\text { OWER }\end{array}$ & $\begin{array}{l}\text { 1. Mahasiswa mampu memahami etika perusahaan, } \\
\text { kepatuhan, dan tata kelola } \\
\text { 2. Mahasiswa mampu mengembangkan pernyataan } \\
\text { misi } \\
\text { 3. Mahasiswa mampu memahami lingkungan risiko } \\
\text { etika } \\
\text { 4. Mahasiswa mampu memahami kode etik perusahaan } \\
\text { 5. Mahasiswa mampumemahami fungsi whistleblowing } \\
\text { 6. Mahasiswa mampu memahami mengaudit fungsi } \\
\text { etika perusahaan }\end{array}$ \\
\hline $\begin{array}{l}\text { BAB IX } \\
\text { DETEKSI DAN } \\
\text { PENCEGAHAN } \\
\text { FRAUD }\end{array}$ & $\begin{array}{l}\text { 1. Mahasiswa mampu memahami dan mengenali fraud } \\
\text { 2. Mahasiswa mampu mendeteksi tanda fraud } \\
\text { 3. Mahasiswa mampu memahami peran akuntan publik } \\
\text { dalam deteksi fraud } \\
\text { 4. Mahasiswa mampu memahami Standar IIA untuk } \\
\text { mendeteksi dan menyelidiki fraud } \\
\text { 5. Mahasiswa mampu memahami investigasi fraud } \\
\text { untuk auditor internal } \\
\text { 6. Mahasiswa mampu memahami proses pencegahan } \\
\text { fraud dengan teknologi informasi } \\
\text { 7. Mahasiswa mampu memahami deteksi fraud dan } \\
\text { auditor internal }\end{array}$ \\
\hline $\begin{array}{l}\text { BAB X AREA } \\
\text { UNTUK AUDIT: }\end{array}$ & $\begin{array}{l}\text { 1. Mahasiswa mampu menentukan lingkup audit } \\
\text { manajemen }\end{array}$ \\
\hline
\end{tabular}




\begin{tabular}{|l|l|}
\hline AUDIT & 2. $\begin{array}{l}\text { Mahasiswa mampu menilai kemampuan audit } \\
\text { UNIVERSE } \\
\text { DAN }\end{array}$ \\
$\begin{array}{l}\text { PROGRAM } \\
\text { AUDIT }\end{array}$ & 3. $\begin{array}{l}\text { Mahasiswa mampu memahami batasan waktu dan } \\
\text { sumber daya audit universe }\end{array}$ \\
& 4. $\begin{array}{l}\text { Mahasiswa mampu menjelaskan konsep audit } \\
\text { universe kepada komite audit dan manajemen } \\
\text { Mahasiswa mampu menyusun program audit: } \\
\text { komponen utama audit universe }\end{array}$ \\
\hline
\end{tabular}

\section{BAB 1}

SIGNIFIKANSI AUDIT INTERNAL DI PERUSAHAAN SAAT INI

\section{Capaian Pembelajaran}

1. Mahasiswa mampu memahami fungsi audit internal.

2. Mahasiswa mampu memahami misi dan tujuan audit internal.

3. Mahasiswa mampu memahami piagam audit internal.

4. Mahasiswa mampu memahami struktur bidang audit internal.

\section{A. Pendahuluan}

Sejarah audit internal berkembang dari waktu ke waktu mengikuti perubahan yang terjadi pada dunia usaha. Audit internal dimulai 3.000 tahun SM yaitu semenjak jaman peradaban Mesopotamia, menggunakan sistem pengendalian intern yang rumit dengan dokumen batu yang berisi kutu, titik, dan tanda centang.. Sejarah mencatat beberapa negara pada waktu itu seperti : Mesir, Cina, Yahudi mulai menerapkan internal audit masih sangat sederhana, misal : setiap penyerahan hasil pertanian ke organisasi desa mensyaratkan adanya dokumen yang syah, sehingga mudah 
diperiksa dan diverifikasi oleh yang berwenang. Berbeda di Yunani dimana orang-orang Yunani lebih mementingkan pengendalian atas transaksi-transaksi keuangan, sedangkan Kerajaan Romawi kuno menerapkan "sistem dengar laporan" dimana verifikasi melalui pelaporan lisan atas semua transaksi keuangan. (Http://mercubuana.ac.id, 2018).

Dimulai ketika terjadi revolusi industri di Inggris (1750-1850), dimana perusahaan-perusahaan mulai mempekerjakan akuntan untuk memeriksa catatan keuangannya melalui jurnal maupun laporan keuangan dan dokumen-dokumen lainnya sebagai bahan bukti. Saat ini dikenal dua tipe dasar auditor perusahaan bisnis yaitu eksternal dan internal. Di Amerika Serikat, auditor eksternal adalah Akuntan Publik Bersertifikat (CPA), yang memiliki lisensi negara dan mengikuti standar Institut Akuntan Publik Amerika dalam melaksanakan tugasnya (AICPA, 2016).

Auditor internal, adalah merupakan karyawan perusahaan, yang secara independen meninjau dan menilai operasi di berbagai bidang, seperti prosedur, akuntansi, pengendalian sistem teknologi informasi, atau proses kualitas manufaktur. Sebagian besar auditor internal mengikuti standar tingkat tinggi yang ditetapkan oleh organisasi profesional, Institute of Auditor internal (https://na.theiia.org, 2018).

Memahami sejarah audit internal adalah penting karena citra lama auditor internal ini masih ada sampai batas tertentu di berbagai tempat di dunia. Hal ini terjadi walaupun karakter fungsi audit internal sekarang sangat berbeda. Seiring waktu, perubahan operasi berbagai perusahaan meningkat dalam volume dan kompleksitas, menciptakan masalah manajerial dan tekanan baru pada manajemen senior. Menanggapi tekanan-tekanan ini, banyak 
manajer senior mengakui pemanfaatan yang lebih baik dari auditor internal mereka.

Definisi audit internal menurut IIA, dan standar profesional yang diterbitkan adalah;

Audit internal adalah fungsi penilaian independen yang didirikan dalam suatu organisasi untuk memeriksa dan mengevaluasi kegiatannya sebagai layanan bagi organisasi.

Fungsi audit internal dalam suatu perusahaan adalah melakukan pemeriksaan terperinci hingga penilaian tingkat lebih tinggi (Moeller.R.R. 2016). Definisi audit internal menurut IIA mencakup sejumlah istilah penting yang berlaku untuk profesi:

a. Independen ketika melakukan audit seorang auditor harus bebas dari pembatasan yang secara signifikan dapat membatasi ruang lingkup dan efektivitas setiap tinjauan dan pelaporan hasil akhir dan kesimpulan.

b. Penilaian auditor internal harus melakukan evaluasi atas bukti audit ketika mereka mengembangkan kesimpulan.

c. Mapan setiap perusahaan modern harus ada fungsi audit internal yang formal.

d. Memeriksa dan mengevaluasi istilah ini menunjukkan peran aktif auditor internal, pertama untuk penyelidikan fakta dan kemudian untuk evaluasi penilaian.

e. Aktivitasnya mengonfirmasi merupakan pekerjaan audit internal yang berlaku untuk semua proses dan aktivitas perusahaan modern.

f. Layanan mengungkapkan bahwa bantuan kepada komite audit, manajemen, dan anggota perusahaan lainnya merupakan produk dari semua pekerjaan audit internal.

Ketika perusahaan menetapkan perencanaan dan kemudian mulai mengimplementasikannya, audittor harus memantau operasi 
untuk memastikan pencapaian tujuan yang ditetapkan. Peran khusus audit internal adalah untuk membantu mengukur dan mengevaluasi pengendalian yang ada dalam perusahaan. Dengan demikian auditor internal harus memahami perannya sebagai fungsi pengendalian dan sifat serta cakupan jenis pengendalian lainnya dalam perusahaan secara keseluruhan .

Auditor internal harus memiliki keahlian membuat desain dan implementasi terbaik dari semua jenis pengendalian dan praktik pengendalian di perusahaan. Keahlian ini mencakup memahami keterkaitan berbagai pengendalian dan integrasi terbaik dalam sistem pengendalian internal. Dengan demikian melalui pintu pengendalian intern auditor internal dapat memeriksa dan mengevaluasi semua kegiatan dan memberikan layanan maksimal kepada perusahaan secara keseluruhan. Auditor internal bertugas untuk membantuperusahaan mencapai hasil yang lebih efektif dengan menilai pengendalian yang ada dan memberikan dasar untuk membantu meningkatkannya.

\section{B. Latar Belakang Audit Internal}

Pada tahun 1930 fungsi audit internal belum diakui sebagai proses penting oleh banyak perusahaan. Pengakuan muncul ketika pembentukan Komisi Sekuritas dan Bursa AS (SEC) pada tahun 1934. Ketika Amerika Serikat dan juga seluruh dunia mengalami depresi ekonomi yang besar. Sebagai tindakan perbaikan legislatif, SEC mensyaratkan bahwa semua perusahaan yang terdaftar di SEC harus memberikan laporan keuangan yang disertifikasi oleh auditor independen. Persyaratan ini yang mendorong perusahaan untuk membentuk departemen audit internal, tetapi dengan tujuan terutama untuk membantu auditor independen.

Meningkatnya kompleksitas bisnis modern telah menciptakan kebutuhan akan auditor internal untuk menjadi spesialis yang 
semakin besar dalam berbagai pengendalian bisnis. Dalam bisnis kecil, pemilik atau manajer akan melakukan tinjauan pengendalian internal sampai batas tertentu untuk semua karyawan perusahaan. Dalam semua situasi ini, penilaian atau fungsi audit internal dilakukan secara langsung sebagai bagian dari peran manajemen dasar. Namun, ketika operasi suatu perusahaan menjadi lebih produktif dan kompleks, maka pemilik atau manajer puncak tidak memiliki waktu yang cukup untuk kontak dengan semua operasi untuk meninjau efektivitas kinerja perusahaan.

Penugasan audit internal biasanya untuk memenuhi kebutuhan operasional yang sangat mendasar yaitu meninjau apakah aset perusahaan dilindungi dengan baik, apakah prosedur dan kebijakan perusahaan dipatuhi, dan apakah catatan keuangan dipelihara secara akurat. Dengan demikian audit internal dapat dipandang sebagai perpanjangan terkait erat pekerjaan auditor eksternal.

Selanjutnya auditor internal memprakarsai jenis layanan baru, secara bertahap mengambil tanggung jawab yang lebih luas dan lebih berorientasi pada manajemen. Selanjutnya, pekerjaan penilaian audit internal mulai diperluas untuk mencakup banyak bidang nonkeuangan di perusahaan.

Kerangka pengendalian internal coso dan persyaratan Sarbanes - Oxley Act (SOx) 2002, mendorong peningkatan kebutuhan akan layanan yang berkelanjutan dari auditor internal. Selain itu, auditor internal saat ini harus sangat tertarik dengan isuisu tata kelola, risiko, dan kepatuhan (GRC) (Moeller.R.R. 2016).

Audit internal saat ini melibatkan spektrum yang luas dari jenis kegiatan operasional dan tingkat cakupan. Audit internal telah bergerak lebih dari sekadar aktivitas staf yang sering kali terkait dengan departemen pengawasan, ke fungsi melapor kepada komite 
audit hal ini yang menjadi pendorong utama perubahan bagi auditor internal. Auditor internal modern secara formal dan aktif melayani komite audit, dewan direksi. Kepala eksekutif audit, memiliki komunikasi langsung dan aktif dengan komite audit. Situasi ini mencerminkan kemajuan besar dalam lingkup cakupan audit internal dan tingkat layanan ke semua area perusahaan.

Oleh sebab itu sebagai auditor internal harus lincah dalam hal berfikir untuk memberikan kontribusi terbaik terhadap bisnis yang sedang diinisiasi oleh perusahaan. Kelincahan seorang auditor internal itu sangat dibutuhkan dalam kondisi yang makin hari semakin rumit dan perlu pemanfaatan waktu yang efektif untuk mengurangi kemungkinan energi terkuras bila tidak segera ada solusi atas permasalahan yang sudah teridentifikasi. Kelincahan seorang auditor internal sangat ditentukan oleh pemahaman terhadap perannya dan perspektifnya atas fungsinya dalam organisasi beserta tanggungjawabnya terhadap perusahaan.

Ada semangat dan pemahaman yang mendalam yang harus diukur melalui kejujuran profesional dalam berperan. Ada ukuran dan standar yang harus dipelajari dan digunakan secara berkesinambungan serta mengkinikan pemahaman akan standarstandar yang bernilai untuk selanjutnya didilaksanakan dalam praktik. Auditor memiliki selalu menumbuhkan kompetensi dan pengetahuan agar sesuai tantangan masa depan. Auditor Internal harus tumbuh dalam realita kehidupan yang semakin menuntut kecepatan dalam segala hal. (Gultom, 2018)

\section{Piagam Auditor Internal.}

Organisasi profesional auditor internal (The Institute of Auditor internal , 2017), IIA, telah memutuskan bahwa semua fungsi audit internal perlu memiliki pernyataan misi yang mendukung profesi tersebut. Misi audit internal adalah: 
Untuk meningkatkan dan melindungi nilai organisasi dengan memberikan para pemangku kepentingan jaminan, saran, dan wawasan berbasis risiko dan obyektif

Ini adalah konsep yang berharga untuk membantu memahami peran dan pentingnya audit internal. Tujuan dari pernyataan misi audit internal adalah untuk memberikan auditor internal pemahaman yang jelas tentang apa yang harus mereka capai dalam perusahaan mereka.

Komponen Penting Piagam Audit Internal IIA telah mengidentifikasi tujuh komponen utama yang mendukung kekuatan dan efektivitas keseluruhan kegiatan audit internal dan harus dicakup dalam piagam audit internal. Jika piagam audit internal tidak mencakup semua komponen ini, dapat melemahkan piagam audit internal dan, pada akhirnya, melemahkan aktivitas audit internal.

\section{Misi dan Tujuan:}

a. Misi audit internal adalah untuk meningkatkan dan melindungi nilai organisasi dengan memberikan asurans, saran, dan wawasan berbasis risiko yang objektif.

b. Tujuan audit internal adalah untuk menyediakan jasa asurans dan konsultasi yang independen dan objektif, yang dirancang untuk meningkatkan nilai dan operasi organisasi.

\section{Standar Internasional Praktik Profesional Audit Internal:}

Audit internal harus memastikan seluruh kegiatannya telah mematuhi unsur-unsur wajib Kerangka Praktik Profesional Internasional (IPPF) IIA termasuk Standar, Prinsip Inti Praktik Profesional Audit Internal, Definisi Audit Internal dan Kode Etik.

\section{Kewenangan - Piagam harus mencakup:}


a. Pernyataan tentang hubungan pelaporan fungsional dan administrasi dalam organisasi.

b. Pernyataan bahwa fungsi oversight akan menetapkan, memelihara dan memastikan bahwa kegiatan audit internal memiliki wewenang yang cukup untuk memenuhi tugasnya dengan:

1) Menyetujui piagam audit internal.

2) Menyetujui rencana audit internal yang tepat waktu, berbasis risiko, dan tangkas.

3) Menyetujui anggaran dan rencana sumber daya audit internal.

4) Menerima komunikasi tepat waktu dari kepala eksekutif audit tentang kinerja audit internal relatif terhadap rencana audit internalnya.

5) Berpartisipasi aktif dalam diskusi terkait pengangkatan dan pemberhentian kepala eksekutif audit untuk memutuskan persetujuannya.

6) Berpartisipasi aktif dalam diskusi terkait remunerasi kepala eksekutif audit untuk memutuskan persetujuannya.

7) Menanyakan kepada manajemen dan kepala eksekutif audit apakah ada ruang lingkup yang tidak tepat atau keterbatasan sumber daya audit internal.

8) Membuat dan menyetujui pernyataan bahwa kepala eksekutif audit akan memiliki akses tidak terbatas ke fungsi oversight serta dapat berkomunikasi dan berinteraksi langsung dengan fungsi oversight tanpa kehadiran manajemen.

9) Membuat dan menyetujui kewenangan bahwa auditor internal akan memiliki akses tidak terbatas atas semua 
fungsi,catatan, properti, dan personel yang berkaitan dengan pelaksanaan pekerjaannya, dan bertanggung jawab atas kerahasiaan dan catatan dan informasi tersebut.

\section{Independensi dan Objektivitas mencakup:}

a. Pernyataan bahwa kepala eksekutif audit akan memastikan bahwa aktivitas audit internal bebas dari kondisi yang mengancam kemampuan audit internal untuk melakukan pekerjaannya dalam keadaan yang tidak memihak. Jika independensi atau objektivitas audit internal terganggu secara fakta maupun penampilan, kepala eksekutif audit akan mengungkapkan rincian potensi penurunan independensi dan objektivitas audit internal kepada pihakpihak yang tepat.

b. Pernyataan bahwa kegiatan audit internal tidak memiliki tanggung jawab atau wewenang operasional langsung atas kegiatan yang diaudit.

c. Pernyataan bahwa jika kepala eksekutif audit memiliki atau diharapkan memiliki peran dan / atau tanggung jawab di luar audit internal, kerangka pengaman akan dibuat untuk membatasi terjadinya penurunan independensi dan obyektivitas.

5. Kewajiban bagi kepala eksekutif audit untuk mengkonfirmasi setidaknya setiap tahun atas independensi kegiatan audit internal kepada fungsi oversight.

6. Independensi dan Objektivitas mencakup:

a. Pernyataan bahwa kepala eksekutif audit akan memastikan bahwa aktivitas audit internal bebas dari kondisi yang mengancam kemampuan audit internal untuk melakukan pekerjaannya dalam keadaan yang tidak memihak. Jika 
independensi atau objektivitas audit internal terganggu secara fakta maupun penampilan, kepala eksekutif audit akan mengungkapkan rincian potensi penurunan independensi dan objektivitas audit internal kepada pihakpihak yang tepat.

b. Pernyataan bahwa kegiatan audit internal tidak memiliki tanggung jawab atau wewenang operasional langsung atas kegiatan yang diaudit.

c. Pernyataan bahwa jika kepala eksekutif audit memiliki atau diharapkan memiliki peran dan / atau tanggung jawab di luar audit internal, kerangka pengaman akan dibuat untuk membatasi terjadinya penurunan independensi dan obyektivitas.

d. Kewajiban bagi kepala eksekutif audit untuk mengkonfirmasi setidaknya setiap tahun atas independensi kegiatan audit internal kepada fungsi oversight.

\section{Lingkup Kegiatan Audit Internal mencakup:}

a. Pernyataan bahwa ruang lingkup kegiatan audit internal meliputi, tetapi tidak terbatas pada, pemeriksaan objektif dengan tujuan memberikan penilaian independen terhadap kecukupan dan efektivitas tata kelola, manajemen risiko, dan proses pengendalian.

b. Pernyataan bahwa kepala eksekutif audit akan melaporkan secara berkala kepada manajemen dan fungsi oversight atas hasil kerja audit internal.

\section{Tanggung jawab mencakup:}

a. Menyampaikan setidaknya setiap tahun rencana audit internal berbasis risiko. 
b. Berkomunikasi dengan manajemen dan fungsi oversight dampak keterbatasan sumber daya pada rencana audit internal.

c. Memastikan aktivitas audit internal memiliki akses terhadap sumber daya yang berkaitan dengan kompetensi dan keterampilan.

d. Mengelola aktivitas audit internal dengan tepat sehingga dapat memenuhi mandatnya.

e. Memastikan kesesuaian dengan Standar IIA.

f. Mengkomunikasikan hasil pekerjaannya dan memantau tindakan korektif yang disepakati.

g. Koordinasi dengan penyedia asurans lainnya.

9. Program Kualitas Asurans dan Peningkatan audit internal mencakup:

a. Pernyataan bahwa kegiatan audit internal akan mengelola program kualitas asurans dan program peningkatan audit internal yang mencakup semua aspek kegiatan audit internal termasuk evaluasi kesesuaiannya dengan Standar IIA.

b. Kewajiban bagi kepala eksekutif audit untuk melaporkan secara berkala hasil dari program kualitas asurans dan peningkatan audit internal kepada manajemen dan fungsi oversight dan memastikan dilakukannya penilaian eksternal atas kegiatan audit internal setidaknya setiap lima tahun sekali

\section{Struktur Bidang Audit Internal}

Bidang audit mewakili tugas-tugas inti audit internal. karenanya, sebagian besar permintaan audit dapat diklasifikasi dalam bidang audit. Setiap bidang audit ini memiliki beberapa 
lingkup inti, yang pada gilirannya berisi lingkup kunci di tingkat yang lebih rendah.

Bidang audit yang ditunjukkan pada gambar 1.1 berdasarkan cakupan yang berbeda menggunakan metode audit yang berbeda pula. Namun, pada akhirnya, semua audit dilakukan sesuai dengan model proses standar. Pada pandangan pertama, bidang audit tampaknya independen satu sama lain, tetapi mereka memiliki kesamaan. Misalnya, audit kecurangan juga dapat mencakup audit keuangan. Hal yang sama berlaku untuk audit bisnis. Audit operasional secara teratur merupakan bagian dari audit apa pun.

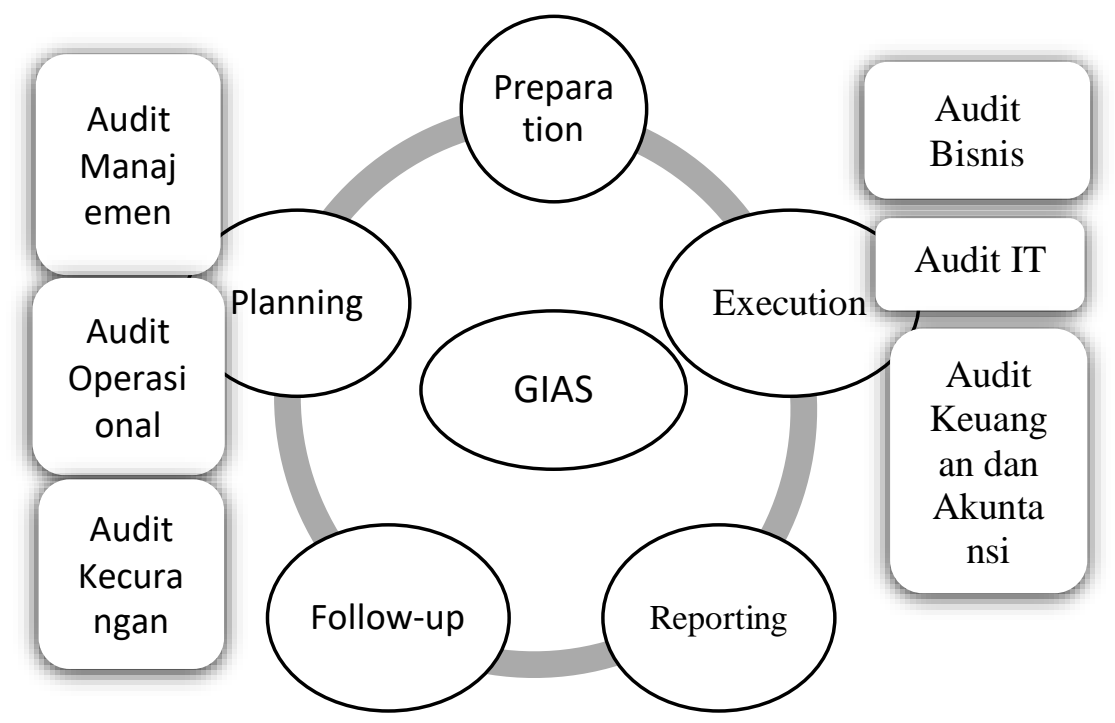

Gambar : 1.1 Tinjauan umum bidang Audit

Sumber : (Kagermann, 2008)

\section{Audit Manajemen}


Dalam audit manajemen auditor internal menguji apakah manajemen mematuhi kebijakan, pedoman, dan prosedur yang ada dan secara umum meninjau pengendalian internal yang efektif dan efisien. Ada dua jenis audit manajemen utama yaitu audit kepatuhan dan efektivitas dan efisiensi. Audit manajemen memeriksa semua rantai proses yang ditangani manajer sebagai bagian dari tugas strategis dan operasional.

Ketika melakukan audit manajemen auditor internal menggunakan sejumlah prosedur, dokumen, dan spesifikasi eksternal yang ada. Misalnya, auditor internal harus memeriksa apakah kebijakan dan pedoman di seluruh perusahaan diterapkan.

Audit manajemen juga memeriksa kepatuhan terhadap persyaratan pelaporan hukum dan keuangan. Auditor internal harus memastikan bahwa manajemen melaksanakan persyaratan hukum telah diterapkan secara lengkap, dan benar. Pemeriksaan pengendalian manajemen sangat penting untuk memastikan kepatuhan terhadap kebijakan, pedoman, dan prosedur. Pengendalian manajemen harus ditetapkan untuk semua kegiatan, termasuk penetapan tujuan, pengembangan dan aplikasi proses, implementasi keputusan, dan kegiatan informasi dan dokumentasi. Audit manajemen secara umum dilakukan atas permintaan dewan komisaris dengan beberapa alasan.

\section{Audit Operasional}

Audit operasional dapat mempengaruhi hampir semua unit bisnis operasional. Audit biasanya terdiri dari semua masalah desain proses, pengendalian internal, perlindungan risiko, dan setiap akun keuangan yang relevan. Di bawah prinsip materialitas, harus dipilih secara cermat proses bisnis inti yang 
akan diaudit dan unit bisnis yang terpengaruh. Proses yang kurang penting atau tidak terpapar risiko yang mengancam keberadaan perusahaan atau keberhasilan bisnisnya dimasukkan dalam rencana audit tahunan sesuai dengan profil risikonya.

Fungsi utama audit operasional adalah untuk meningkatkan kinerja organisasi dan alur kerja perusahaan. Dalam hal ini, audit berfokus pada analisis struktur organisasi, serta proses atau transaksi individu. Tujuannya adalah untuk memastikan bahwa semua rekomendasi sesuai dengan aturan dan peraturan yang relevan.

Selain analisis proses, jenis pekerjaan lapangan lain diperlukan untuk menguji aplikasi proses. Wawancara harus dilakukan untuk menentukan apakah karyawan mematuhi semua pedoman dan instruksi serta proses dilaksanakan seperti yang dirancang. Wawancara-wawancara ini akan menunjukkan sejauh mana karyawan memahami prosesnya. Pemeriksaan dokumen seperti pedoman, kontrak, ekstrak dari daftar komersial, surat kuasa, harus dimasukkan dalam audit. Oleh karena itu, audit operasional mencakup lebih dari pengujian pengendalian internal saja.

\section{Audit Keuangan dan Akuntansi}

Audit keuangan umumnya didefinisikan sebagai evaluasi independen dari data akuntansi masa lalu untuk tujuan menilai apakah data ini sesuai, dan dapat diandalkan, untuk melindungi aset perusahaan, dan didukung oleh pengendalian intern yang memadai. Fokus utama audit keuangan adalah memeriksa data akuntansi dan keuangan organisasi.

Auditor internal memeriksa bidang-bidang seperti akun keuangan perusahaan, sistem penggajian, manajemen aset, 
dan laporan keuangan tahunan. berikut adalah dua opsi dalam hal ini:

a. Akun dan data keuangan diuji secara keseluruhan, berdasarkan analisis laporan keuangan, atau

b. Akun dan item individual dapat diperiksa secara spesifik menggunakan sampel yang memenuhi syarat.

Jika data keuangan harus diperiksa secara keseluruhan, disarankan untuk menganalisis laporan keuangan terlebih dahulu. Untuk tujuan ini, data dari neraca dan laporan laba rugi yang akan diaudit harus dibandingkan dengan angka yang sesuai pada periode sebelumnya dan dianalisis untuk setiap item atau perbedaan yang tidak biasa. Selain perbandingan periode, perbandingan terkait objek juga dapat dilakukan, (misalnya, membandingkan antara beberapa anak perusahaan lokal dengan ukuran yang sama dan dengan kegiatan bisnis yang sebanding). perbandingan dapat dibuat dengan menggunakan angka absolut atau dengan menghitung rasio kunci tertentu (mis., rasio akuntansi tertentu seperti rasio utang / ekuitas, rasio proit, kas terendah dII). selanjutnya, rasio harus dibandingkan dengan angka-angka eksternal, seperti rasio yang sesuai di organisasi rekan. Ini dapat membantu auditor mengidentifikasi item-item yang tidak biasa yang dipilih dari neraca dan laporan laba rugi.

\section{Audit TI}

Tujuan audit TI yang dilakukan oleh audit internal adalah untuk menguji struktur dan proses sistem yang relevan untuk penyelarasannya dengan $\mathrm{TI}$, termasuk kepatuhan terhadap pedoman yang berlaku dan mitigasi risiko. Bidang audit ini mencakup semua masalah terkait proses, mulai dari organisasi, struktur, dan prosedur melalui otorisasi akses, perlindungan 
data dan antivirus. Di perusahaan sotware seluruh pengembangan sotfware proses dapat memiliki pengaruh pada audit TI. Berikut ini adalah tujuan utama audit di bidang teknologi informasi:

a. Pengendalian harus ada untuk memastikan bahwa semua proses $\mathrm{TI}$ mencakup fungsi pemrosesan data yang diperlukan memenuhi standar keamanan yang relevan pada saat sistem digunakan.

b. Proses $\mathrm{TI}$ harus mematuhi kebijakan, pedoman, dan standar perusahaan terbaru serta kewajiban hukum.

\section{Audit Kecurangan}

Audit kecurangan ditujukan khusus untuk mengidentifikasi dugaan kelemahan organisasi dan proses, menyelidiki informasi spesifik tentang penyimpangan, atau mengumpulkan bukti untuk kasus-kasus kecurangan yang sudah terbukti. Dalam konteks ini, sangat penting untuk menetapkan apakah dan sejauh mana kecurangan telah menyebabkan konsekuensi keuangan yang dapat diukur secara langsung, atau setidaknya secara tidak langsung terkait kerugian bagi perusahaan.

Kecurangan yang tidak memiliki dampak keuangan tidak boleh diabaikan atau diremehkan, karena dapat menyebabkan kerusakan pada reputasi perusahaan, kerusakan lingkungan, pengunduran diri staf, cacat produk dan layanan, dan hilangnya kepercayaan terkait.

Untuk memperoleh hasil audit yang dapat digunakan dalam waktu sesingkat mungkin, audit kecurangan biasanya menggunakan berbagai prosedur audit yang tersedia, dari pendekatan proses yang komprehensif, termasuk lingkup dan program kerja, melalui audit ad-hoc khusus yang ditargetkan. Karena audit kecurangan sebagian besar dilakukan di bawah 
tekanan waktu, pengetahuan dan pengalaman di bidang yang diaudit memiliki manfaat besar.

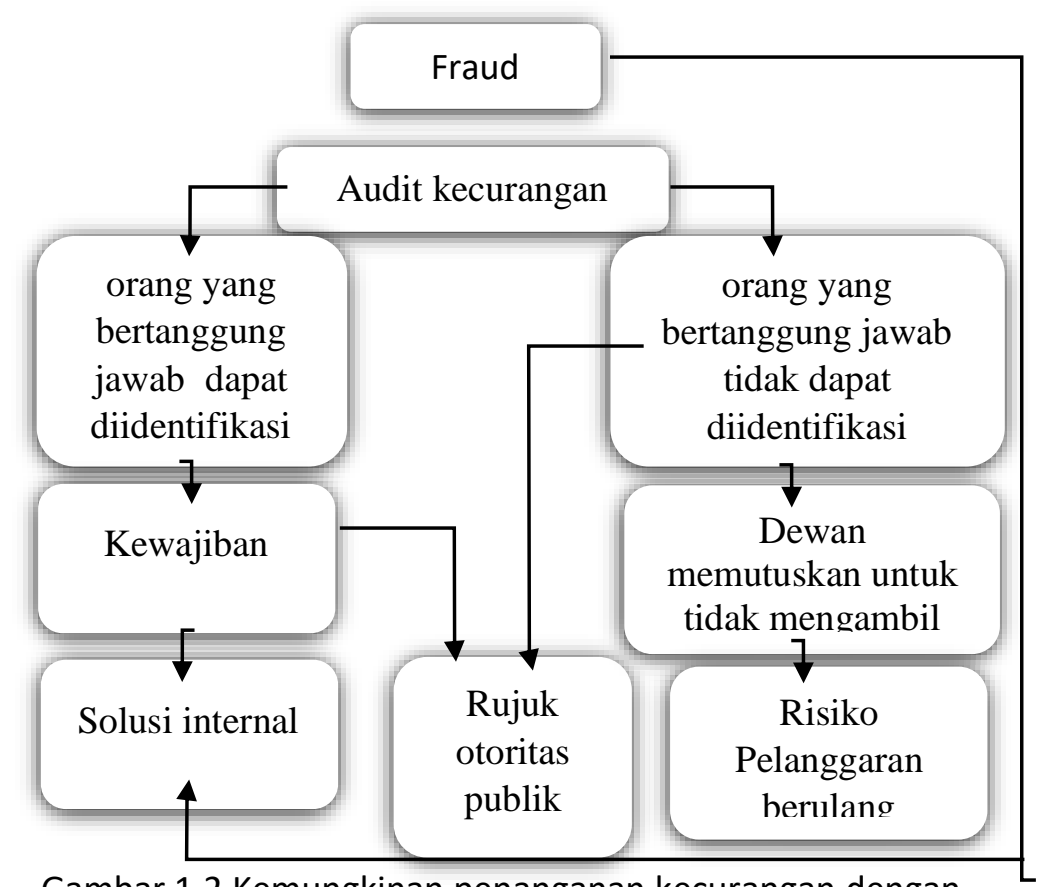

Gambar 1.2 Kemungkinan penanganan kecurangan dengan audit internal

Sumber : (Kagermann, 2008)

Untuk meningkatkan efisiensi pekerjaan yang dilakukan oleh auditor internal dalam bidang audit yang sangat kritis ini. Prosedur audit harus ditentukan untuk setiap kasus kecurangan. Diagram berikut menunjukkan kemungkinan solusi dan saling ketergantungan yang ada dalam penanganan audit kecurangan. Umumnya, investigasi kecurangan ditujukan untuk mengidentifikasi pelaku yang tidak dikenal.

\section{Audit Bisnis}

Audit bisnis didefinisikan sebagai tindakan audit preventif yang dilakukan sejalan dengan strategi de-eskalasi. Tujuan 
utamanya adalah untuk memastikan bahwa proses, metode, dan pedoman sesuai dan berfungsi sebagaimana dimaksud. Pada saat yang sama, risiko yang terkait dengan proyek atau mitra diperiksa dan, jika perlu, diusulkan langkah-langkah pengurangan eskalasi. Tujuan dan isi audit bisnis harus didefinisikan dengan tepat. Audit dapat fokus pada masalah hukum, kontrak, atau organisasi.

Meningkatnya ketergantungan pada rantai pasokan dan layanan, baik di dalam perusahaan maupun di berbagai organisasi, sektor bisnis, dan negara, telah berkontribusi besar dalam memperluas berbagai faktor yang menentukan keberhasilan organisasi. trennya akan berlanjut. Pada akhirnya, jaringan pemasok, pelanggan, mitra, dan kepentingan keuangan serta hubungan dengan lembaga publik, organisasi dan badan pemerintah memiliki pengaruh yang signifikan terhadap proses internal perusahaan. Ini berarti area utama audit internal ditentukan oleh keprihatinan internal dan eksternal.

Pentingnya audit yang terkait dengan masalah eksternal akan terus meningkat seiring meningkatnya ketergantungan organisasi pada mitra eksternal. Saat melakukan audit bisnis, auditor internal memeriksa seluruh lingkungan audit secara mendalam menggunakan roadmap audit. Pada saat audit bisnis, auditor melakukan semua langkah audit individu, termasuk dokumentasi yang diperlukan. Secara keseluruhan, hasil audit bisnis mencakup temuan dan rekomendasi, sedangkan tinjauan bisnis hanya diakhiri dengan proposal prosedural. 


\section{E. Contoh Kasus Audit Internal Aset Tetap}

Pada Desember 2006 Indonesia Corruptin Watch (ICW) melaporkan kasus dugaan korupsi ke Komisi Pemberantasan Korupsi (KPK) dalam ruislaag (tukar guling) antara asset PT. Industri Sandang Nusantara (ISN), sebuah BUMN yang bergerak di bidang tekstil, dengan asset PT. GDC, sebuah perusahaan swasta. Dalam ruislaag tersebut PT. ISN menukarkan tanah seluas 178.497 meter persegi di kawasan Senayan dengan Tanah seluas 47 hektar beserta Pabrik dan mesin di karawang.

Berdasarkan hasil temuan Badan Pemeriksaan Keuangan (BPK) semester II Tahun Anggaran 1998/1999, menyatakan ruislaag itu berpotensi merugikan keuangan Negara sebesar Rp. 121,628 miliar.

Kerugian itu terdiri dari kekurangan luas bangunan pabrik dan mesin milik PT. GDC senilai Rp. 63,954 miliar, berdasarkan penilaian aktiva tetap oleh PT. Sucofindo pada 1999; penyusutan nilai asset pabrik milik PT. GDC senilai Rp. 31,546 miliar; dan kelebihan perhitungan harga tanah senilai Rp. 0,127 miliar. Selain itu juga ditemukan bahwa terdapat nilai saham yang belum dibayarkan oleh PT. GDC sebesar Rp. 26 miliar.

\section{Solusi}

Seharusnya keputusan Tukar Guling tidak hanya menjadi wewenang salah satu pejabat saja, melainkan melibatkan beberapa pejabat sebagai pengendali dan control yang baik. Selain itu juga diperlukan sebuah aturan baku oleh perusahaan mengenai tukar guling, sehingga kemungkinan penyelewengan menjadi berkurang.

Diperlukan juga control dari lembaga bersangkutan terhadap penelitian tim penilik yang meneliti kelengkapan mengenai status asset, dokumen kelengkapan asset, sehingga 
tidak ada manipulasi dari nilai asset tersebut serta proses tukar menukar.

Dari kasus diatas dapat dibuktikan bahwa PT. ISN memiliki pengendalian intern yang sangat buruk. Sehingga PT. ISN rawan dicurangi oleh rekanan-rekanan bisnisnya maupun oleh oknum-oknum pejabat perusahaan yang ingin mengambil keuntungan. Oleh karena itu hal pertama yang harus dibenahi oleh PT. ISN adalah soal Pengendalian Internnya.

\section{F. Simpulan}

1. Memahami sejarah audit internal adalah penting karena citra lama auditor internal ini masih ada sampai batas tertentu di berbagai tempat di dunia. Hal ini terjadi walaupun karakter fungsi audit internal sekarang sangat berbeda. Seiring waktu, perubahan operasi berbagai perusahaan meningkat dalam volume dan kompleksitas, menciptakan masalah manajerial dan tekanan baru pada manajemen senior. Menanggapi tekanan-tekanan ini, banyak manajer senior mengakui pemanfaatan yang lebih baik dari auditor internal mereka.

2. Audit internal saat ini melibatkan spektrum yang luas dari jenis kegiatan operasional dan tingkat cakupan. Auditor internal modern secara formal dan aktif melayani komite audit, dewan direksi. Kepala eksekutif audit, memiliki komunikasi langsung dan aktif dengan komite audit. Situasi ini mencerminkan kemajuan besar dalam lingkup cakupan audit internal dan tingkat layanan ke semua area perusahaan.

3. Komponen Penting Piagam Audit Internal IIA telah mengidentifikasi tujuh komponen utama yang mendukung kekuatan dan efektivitas keseluruhan kegiatan audit internal dan harus dicakup dalam piagam audit internal. Jika piagam audit internal tidak mencakup semua komponen ini, 
dapat melemahkan piagam audit internal dan, pada akhirnya, melemahkan aktivitas audit internal.

4. Bidang audit terdiri dari audit bisnis, audit IT, audit keuangan dan akuntansi, audit operasonal, audit kecurangan, dan audit manajemen

Pertanyaan untuk didiskusikan

1. Jelaskan sejarah audit internal!

2. Jelaskan dampak $4 \mathrm{G}$ dan revoolusi industri 4.0 bagi auditor internal!

3. Mengapa mahasiswa akuntansi harus mempelajari mata kuliah pengauditan internal?

4. Jelaskan pemahaman anda tentang piagam audit internal!

5. Sebutkan dan jelaskan struktur bidang audit internal!

Soal Kasus

Hanya dalam waktu dua tahun, konektivitas seluler generasi berikutnya akan menjadi kenyataan dan menjanjikan sebuah lompatan kuantum di dunia teknologi. Jaringan ini - yang dikenal sebagai 5G - akan memberikan peluang signifikan dalam mentransformasi organisasi di seluruh industri dan wilayah geografis. Jaringan ini menjanjikan penghilangan batasan lokasi secara virtual dan membuat organisasi lebih kuat, lebih terintegrasi, serta lebih produktif. Komunikasi bisnis akan lebih ditingkatkan dan konektivitas akan disesuaikan untuk setiap industri.

Apakah kemunculannya akan mendisrupsi bisnis? Jawaban singkatnya adalah ya. Yang pasti, hal itu akan mampu untuk mendefinisikan ulang seluruh industri, serta membuat industri baru. Tetapi menjaga disrupsi pada tingkat minimum untuk 
kemudahan transisi ke $5 \mathrm{G}$ masih memungkinkan, dan hal tersebut sangatlah penting. Audit internal dapat mendukung transisi yang lancar dan mendorong perubahan positif dengan membantu organisasi menavigasi risiko yang mendisrupsi dan mengelola semua bidang risiko secara efektif. Namun, audit internal tersebut harus mampu berubah ke posisi terbaik mereka untuk fokus pada peluang baru dalam melayani dan memberikan pandangan ke depan mengenai risiko baru yang dimunculkan oleh 5G. Fokus audit ini untuk meneliti implikasi 5G terhadap organisasi dan audit internal, termasuk mengantisipasi adanya perubahan terhadap budaya organisasi, lingkungan kerja, dan rencana bisnis, serta strategi dan kebijakan TI, seperti keamanan dunia maya, manajemen data, dan privasi. Fokus ini juga berupaya melihat apa yang dapat dilakukan audit internal dalam mempersiapkan peluncuran $5 G$ dengan memanfaatkan dan meningkatkan penggunaan teknologi saat ini.

Berdasarkan ilustrasi diatas berikan pendapat anda

1. Implikasi bagi organisasi

2. Bagaimana mengubah budaya dan lingkungan organisasi

\section{Daftar Pustaka}

AICPA. (2016). The American Institute of Certified Public Accountants (AICPA). About the AICPA dapat diunduh www.aicpa.org '.

Audit Internall/AUDIT\%20INTERNAL \%20TM\%201-ok.pdf

Gultom, J. (2018). Agility Dapat diunduh https://jonnygultom.wordpress.com /2018/07/28/agility/. 
Http://mercubuana.ac.id. (2018). Sejarah, perkembangan dan gambaran umum "IA" dapat diunduh pada http://mercubuana.ac.id/files/

https://na.theiia.org. (2018). https://na.theiia.org/standardsguidance/recommended-guidance/practice-guides/Pages/ Engagement-Planning-Assessing-Fraud-Risks.aspx

Kagermann, H. (2008). Internal Audit Handbook. Springer-Verlag Berlin Heidelberg.

Moeller, R. R. (2016). Brink's Modern Internal Auditing Eighth Edition.

The Institute of Auditor internal . (2017). Piagam Audit Internal, dapat diunduh pada na.theiia.org , translations , PP-TheInternal-Audit-Charter-Indonesian. 


\section{BAB 2}

\section{PENGETAHUAN UMUM AUDITOR INTERNAL}

\section{Capaian Pembelajaran}

1. Mahasiswa mampu memahami pentingnya pengendalian internal.

2. Mahasiswa mampu merencanakan audit internal.

3. Mahasiswa mampu mengorganisasi dan mengelola aktivitas audit internal.

4. Mahasiswa mampu memahami struktur bidang audit internal.

5. Mahasiswa mampu memahami dampak teknologi informasi pada audit internal.

6. Mahasiswa mampu memahami audit internal dan tata kelola bisnis

A. Pendahuluan

Auditor internal selayaknya secara berkelanjutan mengembangkan pengetahuan pribadi dan profesional untuk membantu dalam melakukan audit internal. Hal ini untuk menyelaraskan terhadap perubahan standar yang dilakukan oleh Institute of Auditor Internal (IIA) untuk menghadapi revolusi industri, perubahan teknologi seperti penggunaan layanan Web Internet baru. Intinya adalah bahwa auditor internal di semua tingkatan diharapkan memiliki pengetahuan di berbagai bidang, baik yang umum, atau unik dan yang lain mencakup praktek umum audit internal (Rittenberg, 2015a).

Pengetahuan umum auditor internal berfokus pada pengetahuan minimal yang diperlukan oleh setiap auditor internal dalam disiplin itu untuk bekerja secara efektif. 


\section{CBOK}

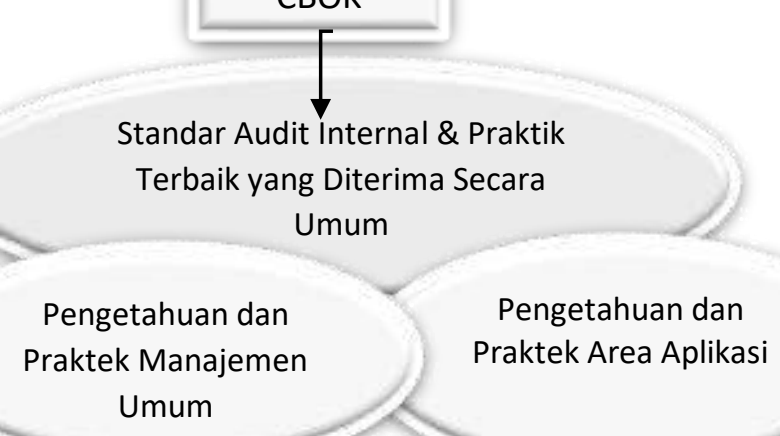

Umum

Gambar 2.1 Relationship of a CBOK to Other Knowledge Areas Sumber : (Moeller.R.R. 2016)

Untuk auditor internal, pengetahuan umum auditor internal mencakup berbagai bidang praktek audit internal yang spesifik, pemahaman praktek manajemen umum, dan beberapa bidang pengetahuan aplikasi umum. Persyaratan ini harus diidentifikasikan atau ditautkan, seperti yang ditunjukkan dalam Gambar 2.1. Konsep ini harus dipertimbangkan untuk semua bidang pengetahuan yang diterbitkan (The Institute of Auditor internal s, 2016).

B. Standar Internasional Untuk Praktek Profesional Auditing Internal

Audit internal dilakukan dalam lingkungan hukum dan budaya yang beragam, untuk organisasi yang berbeda dalam tujuan, ukuran, kompleksitas, dan struktur; dan oleh orang-orang di dalam atau di luar organisasi. Sementara perbedaan dapat mempengaruhi praktik audit internal di setiap lingkungan, oleh sebab itu kesesuaian dengan Standar Internasional IIA untuk Praktik Profesional Audit Internal (Standar) sangat penting dalam memenuhi tanggung jawab auditor internal (The Institute of Auditor internal s, 2016). Tujuan dari Standar ini adalah untuk: 
a. Panduan kepatuhan dengan unsur-unsur wajib Kerangka Praktek Profesional Internasional.

b. Menyediakan kerangka kerja untuk melakukan dan mempromosikan berbagai layanan audit internal nilai tambah.

c. Menetapkan dasar untuk evaluasi kinerja audit internal.

d. Mendorong peningkatan proses dan operasi organisasi.

Standar adalah seperangkat persyaratan wajib berbasis prinsip yang terdiri dari:

a. Pernyataan persyaratan inti untuk praktik profesional audit internal dan untuk mengevaluasi efektivitas kinerja yang dapat diterapkan secara internasional di tingkat organisasi dan individu.

b. Interpretasi yang menjelaskan istilah atau konsep dalam Standar

Standar terdiri dari dua kategori utama: Atribut dan Standar Kinerja. Standar Atribut membahas atribut organisasi dan individu yang melakukan audit internal. Standar Kinerja menggambarkan sifat audit internal dan memberikan kriteria kualitas yang dapat mengukur kinerja layanan ini. Atribut dan Standar Kinerja berlaku untuk semua layanan audit internal.

\section{Standar Atribut}

Standar 1000 Tujuan, Wewenang, dan Tanggung Jawab

Tujuan, kewenangan, dan tanggung jawab aktivitas audit internal harus didefinisikan secara formal dalam suatu piagam audit internal, dan harus sesuai dengan Misi Audit Internal dan unsur-unsur yang diwajibkan dalam Kerangka Kerja Praktik Profesional (Prinsip-prinsip Pokok untuk Praktik Profesional Audit Internal, Kode Etik, Standar dan Definisi Audit Internal). Kepala Audit Internal (KAI) harus mengkaji secara periodik 
piagam audit internal dan menyampaikannya kepada Manajemen Senior dan Dewan untuk memperoleh persetujuan. Standar 1010 Mengakui Panduan Wajib dalam Piagam Audit Internal.

Sifat wajib Prinsip-prinsip Pokok untuk Praktik Profesional Audit Internal, Kode Etik, Standar dan Definisi Audit Internal harus dinyatakan pada piagam audit internal. Kepala Audit Internal harus mendiskusikan Misi Audit Internal dan unsur-unsur yang diwajibkan dari Kerangka Kerja Praktik Profesional Internasional dengan Manajemen Senior dan Dewan

Standar $\mathbf{1 1 0 0}$ Independensi dan Objektivitas

Aktivitas audit internal harus independen dan auditor internal harus obyektif dalam melaksanakan tugasnya.

\section{Standar 1120 - Objektivitas Individu}

Auditor internal harus memiliki sikap yang tidak memihak, tidak memihak, dan menghindari konflik kepentingan.

Standar 1130 - Gangguan terhadap Kemandirian atau Objektivitas

Jika independensi atau objektivitas terlemahkan, baik dalam fakta maupun dalam penampilan (appearance), detail dari pelemahan tersebut harus diungkapkan kepada pihak yang berwenang. Bentuk pengungkapan tergantung pada bentuk pelemahan tersebut.

Standar 1200 Proficiency and Due Professional Care

Penugasan harus dilaksanakan dengan menggunakan keahlian/kecakapan dan kecermatan profesional (due professional care).

Standar 1210 Kecakapan 
Auditor Internal harus memiliki pengetahuan, keterampilan, dan kompetensi lain yang dibutuhkan dalam melaksanakan tugas dan tanggung jawabnya. Aktivitas audit internal, secara kolektif, harus memiliki atau memperoleh pengetahuan, keterampilan, dan kompetensi lain yang dibutuhkan untuk melaksanakan tanggung jawabnya

\section{Standar 1220 Due Professional Care}

Auditor internal harus menerapkan Due Professional Care yang diharapkan dari auditor internal yang cukup bijaksana dan kompeten. Karena Due Professional Care tidak menyiratkan infalibilitas.

\section{Standar 1230 Pengembangan Profesi Berkelanjutan}

Auditor internal harus meningkatkan pengetahuan, keterampilan, dan kompetensi lainnya melalui melanjutkan pengembangan profesional.

\section{Standar 1300 Program Jaminan dan Peningkatan Kualitas}

Eksekutif kepala audit harus mengembangkan dan memelihara jaminan kualitas dan peningkatan program yang mencakup semua aspek kegiatan audit internal.

\section{Standar Kinerja}

\section{Standar 2000 Mengelola Aktivitas Audit Internal}

Eksekutif kepala audit harus secara efektif mengelola kegiatan audit internal untuk memastikan hal itu menambah nilai bagi organisasi.

Aktivitas audit internal dikelola secara efektif ketika:

a. Ini mencapai tujuan dan tanggung jawab yang termasuk dalam piagam audit internal.

b. Ini sesuai dengan Standar.

c. Anggota individualnya mematuhi Kode Etik dan Standar. 
d. Ini mempertimbangkan tren dan masalah yang muncul yang dapat berdampak pada organisasi.

Aktivitas audit internal menambah nilai bagi organisasi dan para pemangku kepentingannya ketika mempertimbangkan strategi, tujuan, dan risiko; berusaha untuk menawarkan cara untuk meningkatkan tata kelola, manajemen risiko, dan proses pengendalian; dan secara objektif memberikan jaminan yang relevan.

\section{Standar 2010 - Perencanaan}

Eksekutif kepala audit harus menetapkan rencana berbasis risiko untuk menentukan prioritas kegiatan audit internal, konsisten dengan tujuan organisasi.

Untuk mengembangkan rencana berbasis risiko, kepala eksekutif audit berkonsultasi dengan manajemen senior dan dewan dan memperoleh pemahaman tentang strategi organisasi, tujuan bisnis utama, risiko terkait, dan proses manajemen risiko. Eksekutif kepala audit harus meninjau dan menyesuaikan rencana, sebagaimana diperlukan, dalam menanggapi perubahan dalam bisnis, risiko, operasi, program, sistem, dan pengendalian organisasi.

\section{Standar 1020 - Komunikasi dan Persetujuan}

Eksekutif auditor kepala harus mengomunikasikan rencana kegiatan audit internal dan persyaratan sumber daya, termasuk perubahan sementara yang signifikan, kepada manajemen senior dan dewan untuk ditinjau dan disetujui. Eksekutif auditor kepala juga harus mengkomunikasikan dampak keterbatasan sumber daya. 


\section{Standar 2030 - Manajemen Sumber Daya}

Eksekutif kepala audit harus memastikan bahwa sumber daya audit internal sesuai, memadai, dan digunakan secara efektif untuk mencapai rencana yang disetujui.

\section{Standar 2040 Kebijakan dan Prosedur}

Eksekutif kepala audit harus menetapkan kebijakan dan prosedur untuk memandu kegiatan audit internal.

\section{Standar 2050 Koordinasi dan Ketergantungan}

Eksekutif pelaksana audit harus berbagi informasi, mengoordinasikan kegiatan, dan mempertimbangkan untuk mengandalkan pekerjaan dari penjamin internal dan eksternal lainnya serta penyedia layanan konsultasi untuk memastikan cakupan yang tepat dan meminimalkan duplikasi upaya.

\section{Standar 2060 Pelaporan ke Manajemen Senior dan Dewan}

Eksekutif kepala audit harus melaporkan secara berkala kepada manajemen senior dan dewan tentang tujuan, wewenang, tanggung jawab, dan kinerja kegiatan audit internal sesuai dengan rencananya dan pada kesesuaiannya dengan Kode Etik dan Standar. Pelaporan juga harus mencakup risiko signifikan dan masalah pengendalian, termasuk risiko penipuan, masalah tata kelola, dan hal-hal lain yang memerlukan perhatian manajemen senior dan / atau dewan.

\section{Standar 2120 Manajemen Risiko}

Kegiatan audit internal harus mengevaluasi efektivitas dan berkontribusi pada peningkatan proses manajemen risiko. Menentukan apakah proses manajemen risiko efektif atau tidak merupakan penilaian yang dihasilkan dari penilaian auditor internal yang:

a. Tujuan organisasi mendukung dan menyelaraskan dengan misi organisasi. 
b. Risiko signifikan diidentifikasi dan dinilai.

c. Respon risiko yang tepat dipilih yang menyelaraskan risiko dengan selera risiko organisasi.

d. Informasi risiko yang relevan ditangkap dan dikomunikasikan secara tepat waktu di seluruh organisasi, memungkinkan staf, manajemen, dan dewan untuk melaksanakan tanggung jawab mereka.

Aktivitas audit internal dapat mengumpulkan informasi untuk mendukung penilaian ini selama berbagai keterlibatan. Hasil dari keterlibatan ini, bila dilihat bersama-sama, memberikan pemahaman tentang proses manajemen risiko organisasi dan efektivitasnya. Proses manajemen risiko dipantau melalui kegiatan manajemen yang sedang berlangsung, evaluasi terpisah, atau keduanya.

\section{Standar 2130 - Pengendalian}

Aktivitas audit internal harus membantu organisasi dalam memelihara pengendalian yang efektif dengan mengevaluasi efektivitas dan efisiensinya dan dengan mendorong peningkatan yang berkelanjutan.

Standar 2130.A1. Kegiatan audit internal harus mengevaluasi kecukupan dan efektivitas pengendalian dalam menanggapi risiko dalam tata kelola, operasi, dan sistem informasi organisasi mengenai:

a. Pencapaian tujuan strategis organisasi.

b. Keandalan dan integritas informasi keuangan dan operasional.

c. Efektivitas dan efisiensi operasi dan program.

d. Perlindungan aset.

e. Kepatuhan terhadap hukum, peraturan, kebijakan, prosedur, dan kontrak. 


\section{Standar 2200 Perencanaan Keterlibatan}

Auditor internal harus mengembangkan dan mendokumentasikan rencana untuk setiap perikatan, termasuk tujuan perikatan, ruang lingkup, waktu, dan alokasi sumber daya. Rencana tersebut harus mempertimbangkan strategi, tujuan, dan risiko organisasi yang relevan dengan perikatan.

\section{Standar 2201 Pertimbangan Perencanaan}

Dalam merencanakan perikatan, auditor internal harus mempertimbangkan:

a. Strategi dan tujuan dari kegiatan yang sedang ditinjau dan sarana yang digunakan untuk mengontrol kinerjanya.

b. Risiko signifikan terhadap tujuan, sumber daya, dan operasi kegiatan serta cara yang dengannya potensi dampak risiko disimpan ke tingkat yang dapat diterima.

c. Kecukupan dan efektivitas tata kelola kegiatan, manajemen risiko, dan proses pengendalian dibandingkan dengan kerangka kerja atau model yang relevan.

d. Peluang untuk membuat perbaikan signifikan pada tata kelola kegiatan, manajemen risiko, dan proses pengendalian

\section{Standar 2210 - Tujuan Keterlibatan}

Tujuan harus ditetapkan untuk setiap keterlibatan.

Standar 2210.A1 Auditor internal harus melakukan penilaian awal terhadap risiko yang relevan dengan aktivitas yang sedang ditinjau. Tujuan keterlibatan harus mencerminkan hasil penilaian ini. 
Standar 2210.A2 Auditor internal harus mempertimbangkan kemungkinan kesalahan signifikan, penipuan, ketidakpatuhan, dan paparan lainnya ketika mengembangkan tujuan keterlibatan.

Standar 2210.A3 Kriteria yang memadai diperlukan untuk mengevaluasi tata kelola, manajemen risiko, dan pengendalian. Auditor internal harus memastikan sejauh mana manajemen dan/atau dewan telah menetapkan kriteria yang memadai untuk menentukan apakah tujuan dan sasaran telah tercapai. Jika memadai, auditor internal harus menggunakan kriteria tersebut dalam evaluasi mereka. Jika tidak memadai, auditor internal harus mengidentifikasi kriteria evaluasi yang sesuai melalui diskusidengan manajemen dan/atau dewan.

\section{Standar 2240 Program Kerja Keterlibatan}

Auditor internal harus mengembangkan dan mendokumentasikan program kerja yang mencapai tujuan pelibatan.

Standar 2240.A1 Program kerja harus mencakup prosedur untuk mengidentifikasi, menganalisis, mengevaluasi, dan mendokumentasikan informasi selama perikatan. Program kerja harus disetujui sebelum penerapannya, dan penyesuaian apa pun segera disetujui.

\section{Standar 2300 Melakukan Pertunangan}

Auditor internal harus mengidentifikasi, menganali sis, mengevaluasi, dan mendokumentasikan informasi yang cukup untuk mencapai tujuan perikatan. 


\section{Standar 2310 Mengidentifikasi Informasi}

Auditor internal harus mengidentifikasi informasi yang cukup, andal, relevan, dan berguna untuk mencapai tujuan perikatan.

\section{Standar 2320 Analisis dan Evaluasi}

Auditor internal harus mendasarkan kesimpulan dan hasil keterlibatan pada analisis dan evaluasi yang sesuai.

\section{Standar 2330 Mendokumentasikan Informasi}

Auditor internal harus mendokumentasikan informasi yang memadai, andal, relevan, dan berguna untuk mendukung hasil dan kesimpulan pertunangan.

Standar 2330.A1 Kepala eksekutif audit harus mengontrol akses ke catatan keterlibatan. Kepala eksekutif audit harus mendapatkan persetujuan manajemen senior dan/atau penasihat hukum sebelumnya untuk melepaskan catatan tersebut kepada pihak eksternal, sebagaimana diperlukan. Standar 2330.A2 Kepala audit eksekutif harus mengembangkan persyaratan retensi untuk catatan pengikatan, terlepas dari media di mana setiap catatan disimpan. Persyaratan retensi ini harus konsisten dengan pedoman organisasi dan yang terkait persyaratan peraturan atau lainnya.

Standar 2330.C1 Kepala eksekutif audit harus mengembangkan kebijakan yang mengatur penahanan dan penyimpanan catatan keterlibatan konsultasi, serta rilis mereka ke pihak internal dan eksternal. Kebijakan ini harus konsisten dengan pedoman rumah sakit dan peraturan terkait lainnya atau persyaratan lainnya.

Standar 2340 Pengawasan Keterlibatan 
Keterlibatan harus diawasi dengan benar untuk memastikan tujuan tercapai, kualitas terjamin, dan staf dikembangkan.

C. Pengetahuan Umum \& Praktek Manajemen

Bidang audit internal sangat luas (Rittenberg, 2015b), bidang pengetahuan yang paling penting bagi auditor internal modern saat ini diantaranya;

a. Sumber pedoman tata kelola dan etika

b. Wawasan risiko strategis

c. Pentingnya pengendalian internal

d. Mengatur dan mengelola kegiatan audit internal

e. Merencanakan dan melakukan audit internal

f. Dampak teknologi informasi pada audit internal

Kepala eksekutip audit harus memiliki teknis keterampilan yang dibutuhkan secara luas untuk kegiatan audit internal:

a. Akuntansi digunakan untuk menilai pengendalian pelaporan keuangan.

b. Jaminan manajemen risiko digunakan untuk audit berbasis risiko dan untuk meningkatkan proses manajemen risiko.

c. Teknologi informasi umum diperlukan untuk menilai proses bisnis dan TI dan melakukan tugas audit.

d. Pengetahuan khusus industri digunakan untuk jaminan, konsultasi, dan tinjauan strategis.

e. Penambangan data dan analitik digunakan untuk meningkatkan efisiensi dan efektivitas prosedur audit.

D. Persyaratan CBOK: Pentingnya Pengendalian Internal

Sekarang ini, kepercayaaan bukanlah sebuah dasar bisnis akan tetapi desain pengendalian intern akan meningkatkan sebuah kepercayaan dalam memulai dan mengelola sebuah bisnis (Stafford \& Thor, 2016). Oleh karena itu, persepsi atas risiko dan desain 
pengendalian intern harus menghasilkan sebuah takaran yang tepat untuk membuat semakin berenergi dan siap melakukan alternatif solusi apabila ada situasi yang berubah secara dinamis dalam tahapan proses.

Pengendalian adalah sebuah pendekatan secara holistik yang membuat perusahaan semakin paham bahwa risiko adalah sisi lain dari sebuah kesempatan untuk sebuah hasil dan juga sebagai modal untuk bertumbuh. Pengendalian internal merupakan sebuah standard bukan aturan, karena standar berisi values, sedangkan aturan cenderung mengarah pada compliance. Standard akan mendidik untuk berfikir dengan framework yang bernilai dengan menalar sitiuasi, kondisi dan fakta-fakta yang ada sehingga ada pola bertindak yang benar, objektif dan disertai integritas (Loughlin, 2016).

Sebuah sistem pengendalian yang yang dikatakan baik adalah apabila sistem tersebut mampu mencegah dan mengurangi risiko yang teridentifikasi secara logis pada proses atau tahaptahapan proses bisnis yang dimiliki oleh entitas tersebut.

Melalui kerangka pengendalian COSO, tentang bagaimana perusahaan harus mengatur dan memikirkan pengendalian internnya. Kerangka kerja pengendalian intern cOSO sekarang menjadi standar dunia untuk menetapkan pengendalian intern yang baik. Kerangka kerja pengendalian internal COSO direvisi tahun 2014, dengan penekanan yang lebih besar pada manajemen fraud dan memahami risiko serta mengembangkan struktur organisasi perusahaan yang tertata kelola dengan baik. COSO sekarang didukung oleh 17 prinsip pengendalian internal, yang merupakan persyaratan utama pengetahuan audit internal (Bailey, 2015). 
E. Persyaratan CBOK: Merencanakan dan Melakukan Audit Internal

\section{Merencanakan Audit Internal}

Selain menciptakan lingkup audit auditor harus membuat perencanaan audit tahunan, puncak dari perencanaan audit tahunan melibatkan penjadwalan, yaitu audit yang disusun selama satu tahun dimasukkan ke dalam minggu dan bulan yang tersedia dengan pertimbangan kapasitas personil. Penyesuaian penugasan selama tahun ini dapat mempengaruhi audit yang masih harus dilakukan. babnya memberikan gambaran umum tentang komponen utama perencanaan audit dan dampaknya terhadap pekerjaan audit sehari-hari (Anderson, 2016).

Fase perencanaan audit tahunan dipecah menjadi beberapa sub-tahap lebih lanjut. Perencanaan audit tahunan dimulai dengan;

a. pembuatan profil risiko untuk semua entitas yang mungkin diaudit relevan.

b. Untuk semua entitas tersebut dibuatlah sebuah profil risiko, dan selanjutnya ditambahkan ke inventaris audit.

c. Rencana audit tahunan kemudian disusun berdasarkan topik-topik dalam inventaris audit dan masing-masing risiko yang terkait

\section{Melaksanakan Audit Internal}

Langkah selanjutnya setelah membuat rencana audit tahunan adalah persiapan rencana pelaksanaan audit yang sebenarnya. Dua poin penting di tingkat terkait kegiatan (Deloach \& Hjelm, 2016):

a. Audit terjadwal harus ditetapkan sesuai dengan jumlah dan keterampilan auditor. Kualifikasi, pengalaman, ketersediaan, dll. 
b. Perencanaan waktu dan urutan berbagai audit adalah masalah yang saling berkaitan erat.

Catatan kinerja audit harus dikonsultasikan untuk memastikan bahwa audit yang dijadwalkan sebenarnya dapat dilakukan berdasarkan kinerja dan persyaratan waktu sebelumnya. Penting juga untuk menjadwalkan kapasitas cadangan untuk audit yang tidak dijadwalkan. Ini memungkinkan pengidentifi kasian kelebihan kapasita atau kurang digunakan pada waktunya untuk membuat penyesuaian terhadap rencana (Barr-pulliam, 2016).

Rencana audit tahunan dimasukkan ke dalam catatan kinerja audit, yang menyediakan statistik tahunan terkini dari audit yang diselesaikan dan status audit yang belumdilakukan. Catatan kinerja audit memberikan gambaran singkat tentang kegiatan audit internal. Catatan kinerja audit dipertahankan secara terpusat, memastikan bahwa seluruh tim audit memiliki pemahaman yang seragam tentang persyaratan kinerja aktual audit internal.

F. Persyaratan CBOK: Mengorganisasi dan Mengelola Aktivitas Audit Internal

Internal audit adalah profesi yang sangat membutuhkan banyak ilmu dan sebagai internal audit harus mengetahui banyaknya ilmu yang dibutuhkan itu, sekalipun tidak akan mampu menguasainya secara mendalam. Pengetahuan itu diperlukan agar auditor internal senantiasa hati-hati dalam berperan dan selalu ada pada posisi due care professionalism (Rittenberg, 2015b).

\section{Mengorganisasi Aktivitas Audit Internal}

Sebagian besar aktivitas audit internal dihadapkan pada keterbatasan waktu dan sumberdaya. Oleh sebab itu Kepala 
Audit Internal harus mengorganisir pelaksanaan audit internal untuk memastikan bahwa sumber daya audit internal telah sesuai, memadai, dan dapat digunakan secara efektif dalam rangka pencapaian rencana audit yang telah disetujui. Kompetensi sumberdaya manusia mengacu pada gabungan dari pengetahuan, kecakapan/keahlian, dan kompetensi lain yang diperlukan untuk melaksanakan rencana audit internal. Memadai mencakup kuantitas sumber daya yang diperlukan untuk mencapai rencana audit internal.

Kepala Audit Internal harus menetapkan kebijakan dan prosedur untuk mengarahkan aktivitas audit internal. Bentuk maupun isi kebijakan dan prosedur tergantung pada ukuran dan struktur aktivitas audit internal, serta kompleksitas pekerjaannya.

\section{Mengelola Pelaksanaan Audit Internal}

Kepala Audit Internal harus mengelola aktivitas audit internal secara efektif untuk meyakinkan bahwa aktivitas tersebut memberikan nilai tambah bagi organisasi. Aktivitas audit internal telah dikelola secara efektif apabila:

a. Mencapai tujuan dan tanggung jawab sebagaimana tercantum pada piagam audit internal;

b. Sesuai dengan Definisi Audit Internal dan Standar;

c. Anggota individual menunjukkan kesesuaiannya terhadap Kode Etik dan Standar;

d. Mempertimbangkan trend dan permasalahanpermasalahan yang timbul yang dapat mempengaruhi organisasi.

Aktivitas audit internal dikatakan memberi nilai tambah bagi organisasi dan pemangku kepentingannya apabila mempertimbangkan strategi, tujuan dan risiko-risiko; berupaya 
keras dalam menyediakan cara untuk mengembangkan proses tata kelola, manajemen risiko, dan pengendalian; dan secara objektif memberikan asurans yang relevan.

G. Persyaratan CBOK: Dampak Teknologi Informasi pada Audit Internal

Pertumbuhan penggunaan IT dalam aktivitas bisnis sudah sangat intensif. Bukan berarti auditor internal menjadi robot di era teknologi, akan tetapi proses berfikir auditor sangat dituntut untuk cepat menyesuaikan dan memanfaatkan sumber daya IT (Rittenberg, 2015c). Termasuk memfasilitasi dukungan IT dalam pekerjaan yang semakin banyak bahkan rumit. Seperti E-working papers dan juga aplikasi lainnya yang bisa membantu melakukan tracking atas kinerja auditor setiap saat atau secara reguler dan periodik. Semua itu akhirnya akan bermuara pada capaian kinerja audit dan bisa digunakan sebagai feedback untuk mendorong disiplin berkinerja yang bisa dipertanggungjawabkan.

Saat ini banyak aplikasi yang bisa dipertimbangkan untuk dibeli atau di desain untuk tujuan yang baik. Perkembangan teknologi yang sangat pesat dan intensif telah membawa perubahan dalam pola bisnis di segala jenis industri. Teknologi sudah menjadi sesuatu yang harus diadopsi agar dapat memenuhi kebutuhan sebuah perusahaan untuk menjangkau pelanggan dan juga sekaligus untuk bisa eksis dalam kompetisi market. Sesungguhnya, teknologi sangat membantu manusia dan pelaku bisnis untuk saling berinteraksi, bertransaksi dan juga saling tukar menukar informasi yang dibutuhkan dalam proses pengambilan keputusan bisnis (Tsintzas, 2016).

Untuk profesi auditor internal, perkembangan teknologi ini juga dapat dimanfaatkan sebagai sarana untuk mengintensifkan peran dam fungsinya untuk bisa memberikan nilai tambah sekaligus untuk membuat pelaksanaan tugasnya semakin efektif 
dan efisien. Hal ini akan sangat terasa gunamya apabila perusahaan sangat mrngandalkan teknologi informasi dalam pemrosesan transaksi serta memberi layanan yang fleksibel bagi pelanggan untuk bertransaksi kapan saja dan di mana saja. Online transactions and 24 hours services!

H. Persyaratan CBOK: Audit Internal dan Tata Kelola Bisnis

Auditor internal sebagai third line of defense, sesuai dengan standard IPPF sangat diharapkan untuk memahami perannya sehingga bisa memberikan kontribusi bagi kemajuan perusahaan dan terhindar dari kerugian-kerugian yang seharusnya bisa dihindari (Rose, 2015).

Diberlakukannya SOx, pengakuan yang semakin besar akan pentingnya pengetahuan umum auditor internal tentang kecurangan tingkat perusahaan, dan pengetahuan umum auditor internal tentang undang-undang baru lainnya yang merubah banyak aspek dari dunia bisnis semakin kompleks. Auditor internal harus mengembangkan pengetahuan umum tentang komunikasi audit internal dengan komite audit dewan direksi. SOx merupakan persyaratan penting, terutama untuk kepala eksekutif audit, serta semua anggota fungsi audit internal harus memiliki pengetahuan umum tentang peran komite audit dalam operasi audit internal. Program etika dan whistleblower, inisiatif penting di banyak perusahaan. Sekali lagi, ini adalah area di mana auditor internal perlu mengembangkan pemahaman pengetahuan umum yang baik tentang program yang efektif.

Memahami deteksi dasar pecurangan dan pengendalian dan pencegahan, harus menjadi persyaratan dasar untuk semua auditor internal. Semua auditor internal harus mendapatkan tingkat pemahaman yang baik dari red flag yang menunjukkan kemungkinan kecurangan dan prosedur peninjauan investigasi 
kecurangan. Pemahaman masalah tata kelola, pelaporan, dan kepatuhan secara keseluruhan dalam lingkungan audit internal dan pengendalian intern saat ini. Auditor internal di seluruh dunia harus selalu mengembangkan pemahaman CBOK yang serupa tentang aturan yang mengatur kepatuhan di negara dan lokasi mereka sendiri (Witzany, 2016).

I. Simpulan

Ingat, internal auditor itu tidak harus sudah memiliki semua ilmu dan pengetahuan. Tapi harus mau belajar dan mampu menggunakan kemampuan serta sumber daya yang dimilikinya. Apabila, belum punya knowledge dan pengalaman yang cukup maka standard practice juga memgharuskan: ada close supervision. Kalau itu tidak ada, maka termasuk violation of the standard.

Pengetahuan umum auditor internal berfokus pada pengetahuan minimal yang diperlukan oleh setiap profesional dalam disiplin itu untuk bekerja secara efektif. Diantaranya, Standar Audit Internal \& Praktik Terbaik yang Diterima Secara Umum, Pengetahuan dan Praktek Manajemen Umum, dan Pengetahuan dan Praktek Area Aplikasi.

Pengendalian internal merupakan sebuah standard bukan aturan, karena standar berisi values, sedangkan aturan cenderung mengarah pada compliance. Standard akan mendidik untuk berfikir dengan framework yang bernilai dengan menalar sitiuasi, kondisi dan fakta-fakta yang ada sehingga ada pola bertindak yang benar, objektif dan disertai integritas

Audit auditor harus membuat perencanaan audit tahunan, puncak dari perencanaan audit tahunan melibatkan penjadwalan, yaitu audit yang disusun selama satu tahun dimasukkan ke dalam minggu dan bulan yang tersedia dengan pertimbangan kapasitas 
personil. Pengetahuan itu diperlukan agar auditor internal senantiasa hati-hati dalam berperan dan selalu ada pada posisi due care professionalism

Untuk profesi auditor internal, perkembangan teknologi ini juga dapat dimanfaatkan sebagai sarana untuk mengintensifkan peran dam fungsinya untuk bisa memberikan nilai tambah sekaligus untuk membuat pelaksanaan tugasnya semakin efektif dan efisien. Memahami deteksi dasar pecurangan dan pengendalian dan pencegahan, harus menjadi persyaratan dasar untuk semua auditor internal.

\section{J. Contoh Kasus}

Restiana Linggadjaya, CIA, CRMA, adalah CAE Bank CIMB Niaga, salah satu bank terbesar di Indonesia. Dia menempatkan prioritas tinggi pada keterampilan jaminan manajemen risiko. Selain itu, ketajaman bisnis juga merupakan keterampilan teknis yang lebih diminati daripada akuntansi, mengingat kebutuhan untuk memahami bisnis dan melihat dampak ekonomi global terhadap bank dan kliennya. Keterampilan TI dan pemahaman bisnis harus bekerja sama, catatnya. Penambangan data, analitik, dan keterampilan teknis lainnya sangat penting, tetapi staf harus memahami bisnis dan prosesnya untuk memanfaatkan data mining dan analitik dengan sebaik-baiknya. TI adalah keterampilan teknis penting lainnya untuk industrinya, mengingat ketergantungan bank yang luar biasa pada sistem TI. Rencana auditnya mencurahkan $16 \%$ waktunya untuk audit $\mathrm{TI}$, yang dua kali lipat dari rata-rata global $8 \%$ yang dilaporkan dalam survei praktisi CBOK 2015.

\section{Solusi}

Bank CIMB Niaga harus membangun sub devisi audit berdasarkan pusat dan cabang, sub divisi audit teknologi dan 
informasi, serta membina staf melalui pelatihan manajemen dan eksposur dengan manajer bisnis utama. Meminta manajer bisnis untuk memberi tahu staf audit tentang ekspektasi mereka untuk layanan audit yang memiliki nilai tambah dari audit internal.

\section{Pertanyaan untuk didiskusikan}

1. Jelaskan kemampuan minimal auditor internal agar bisa bekerja secara efektif!

2. Sebut dan jelaskan standar atribut bagi individu yang melakukan audit internal!

3. Sebut dan jelaskan standar kinerja terkait kreteria kualitas jasa layanan audit internal

4. Sebutkan bidang pengetahuan yang paling penting bagi auditor di era $4 \mathrm{G}$ dan revolusi industri 4.0

\section{Soal kasus}

Saudara adalah auditor internal dari PT Banyu sedang melakukan audit terhadap arus kas 31 Agustus 2020. Aktivitas utama perusahaan adalah makanan dan minuman. Untuk tahun buku yang berakhir 31 Agustus 2020 perusahaan menderita kerugian. Kerugian yang diderita perusahaan disebabkan pandemi COVID 19 sehingga kehilangan pelanggan utamanya yaitu pengecer nasional yang sudah bertahun-tahun memesan makanan dan minuman dengan merek dari pengecer nasional tersebut.

Saat ini perusahaan memfokuskan diri pada merek makanan dan minuman sendiri yang sejak lama laku dipasar dengan margin yang tinggi. Perusahaan juga merencanakan untuk memperluas customer base nya untuk makanan dan minuman terbaru dan telah menandatangani beberapa kontrak dengan beberapa pelanggan baru dari luar negeri. Perusahaan juga telah menegosiasikan sebuah kontrak dengan sebuah supplier utama 
yang menyebabkan turunnya harga beli bahan untuk pembelian bulanan. Selama tahun buku yang berakhir tanggal 31 Agustus 2020, perusahaan mengalami beberapa kali negative cash flow, tapi bisa bertahan berkat fasilitas overdraft dari bank dan memperlambat pembayaran hutang dagang dan pembayaran PPN. Perusahaan mempunyai kredit dari bank XYZ yang jatuh tempo bulan Maret 2021 dan dalam proses negosiasi dengan bank KLM agar dapat melunasi loan dari bank XYZ.

\section{Pertanyaan:}

a. Jelaskan bagaimana saudara merencanakan dan melakukan audit internal arus kas untuk kasus diatas.

b. Jelaskan bagaimana saudara mengorganisasi aktivitas audit arus kas untuk kasus diatas

\section{Daftar Pustaka}

Anderson, D. (2016). Relationships and Risk Insights from Stakeholders in North America.

Barr-pulliam, D. (2016). Engaging Third Parties for Internal Audit Activities.

Bailey, J. A. (2015). Looking to the Future for Internal Audit Standards.

Deloach, J., \& Hjelm, C. L. (2016). Six Audit Committee Imperatives Enabling Internal Audit to Make a Difference.

Loughlin, C. J. O. (2016). Internal Audit Quality Assurance and Improvement $A$ Call to Action

Moeller.R.R. (2016). Brink's Modern Internal Auditing Eighth Edition A Common Body of Knowledge Published by John Wiley \& Sons, Inc., Hoboken, New Jersey.

Rittenberg, L. E. (2015b). Ethics and Pressure, The IIA Research 
Foundations.

Rittenberg, L. E. (2015c). Interacting with Audit Committees The Way Forward for Internal Audit

Rittenberg, L. E. (2015a). Ethics and Pressure.

Rose, J. (2015). The Top 7 Skills CAE's Want Building the Right Mix of Talent for Your Organization.

Stafford, V. H., \& Thor, M. (2016). Achieving Excellence in Assurance , Strategic Risk Insights, and More Viewpoints From Financial Services Stakeholders.

The Institute of Auditor internal s. (2016). Standar Internasional Untuk Praktek Profesional Auditing Internal.

Tsintzas, E. (2016). Lifelong Learning for Auditor internal s.

Witzany, A. (2016). Voice of the Customer Stakeholders ' Messages for Internal Audit. 


\section{BAB 3}

\section{KERANGKA PENGENDALIAN INTERNAL COSO}

\section{Capaian Pembelajaran}

1. Mahasiswa mampu memahami pengendalian internal

2. Mahasiswa mampu memahami kerangka kerja COSO.

3. Mahasiswa mampu memahami kerangka kerja COSO dan perubahan lingkungan.

4. Mahasiswa mampu memahami komponen pengendalian internal COSO : lingkungan pengendalian.

5. Mahasiswa mampu memahami komponen pengendalian internal COSO : penilaian risiko.

6. Mahasiswa mampu memahami komponen pengendalian internal COSO : aktivitas pengendalian internal.

7. Mahasiswa mampu memahami komponen pengendalian internal COSO : informasi dan komunikasi.

8. Mahasiswa mampu memahami komponen pengendalian internal COSO : aktivitas monitoring

\section{A. Pendahuluan.}

Pengendalian intern coso adalah kerangka kerja yang menjabarkan praktik profesional untuk menetapkan sistem dan proses bisnis yang efisien dan efektif. Kerangka kerja pengendalian internal COSO merupakan model panduan penting yang harus diikuti oleh perusahaan ketika mengembangkan proses, sistem, dan prosedur bisnis serta dalam membangun kepatuhan terhadap Sarbanes - Oxley Act (SOx) (Moeller.R.R. 2016). Pemahaman tentang kerangka kerja pengendalian internal COSO merupakan pengatahuan umum yang harus dimiliki auditor internal. 
Kerangka kerja pengendalian internal COSO diluncurkan di Amerika Serikat tahun 1992. Pada saat itu merupakan periode terjadinya beberapa praktik kecurangan bisnis yang signifikan di Amerika Serikat dan di tempat lain. Hal ini mengungkapkan adanya kebutuhan untuk meningkatkan proses pengendalian intern dan panduan prosedur. Kerangka kerja pengendalian internal COSO 1992 menjadi elemen fundamental dari standar audit American Institute of Certified Public Accountants (AICPA) (AICPA, 2016) di Amerika Serikat dan akhirnya menjadi standar untuk auditor eksternal dalam tinjauan mereka untuk yang menyatakan bahwa pengendalian internal perusahaan memadai. Karena sifatnya yang umum menggambarkan praktik pengendalian internal yang baik, kerangka kerja COSO dilakukan beberapa kali revisi terakhir tahun 2014.

Sebagian dari masalahnya adalah bahwa banyak orang melihat pengendalian intern melalui bagan organisasi untuk meninjau tingkat manajemen senior, tingkat menengah di beberapa unit operasinya. Di setiap tingkat, orang melihat pengendalian intern dalam garis otoritas. Namun, prosedur pengendalian seringkali agak berbeda di setiap level dan komponen organisasi. Sehingga berakibat satu unit dapat beroperasi dalam lingkungan bisnis yang diatur di mana proses pengendaliannya sangat terstruktur, sedangkan unit divisi lain dari perusahaan yang sama dengan struktur yang kurang forma. Hal ini menyebabkan setiap tingkat manajemen memiliki perspektif kepedulian pengendalian yang berbeda.

Seluruh masalah definisi pengendalian internal ini diselesaikan pada awal 1990-an ketika sebuah konsorsium organisasi akuntansi dan audit profesional diantaranya;

a. American Institute of Certified Public Accountants AICPA, 
b. Institute of Auditor internal (IIA), dan lainnya

Organisasi-organisasi profesional ini menjadi Comitee of Sponsoring Organizatitions of The Treadway Commission (COSO) yang diberi wewenang oleh pemerintah dan organisasi lainnya untuk mengembangkan definisi tentang pengendalian intern yang baik atau memadai. Komite Organisasi Sponsoring COSO mempekerjakan Pricewaterhouse Coopers, melakukan survei organisasi pengguna yang luas, dan mulai bekerja untuk mengembangkan definisi pengendalian intern.

Kerangka kerja pengendalian internal coso dirilis pada tahun 1992, memberikan deskripsi yang sangat baik tentang konsep multidimensi ini, mendefinisikan pengendalian intern sebagai berikut:

Pengendalian intern adalah suatu proses, yang dilakukan oleh dewan direksi, manajemen, dan personel lain dari suatu entitas, yang dirancang untuk memberikan jaminan yang wajar mengenai pencapaian tujuan dalam kategori berikut:

a. Efektivitas dan efisiensi operasi

b. Keandalan pelaporan keuangan

c. Kepatuhan terhadap hukum dan peraturan yang berlaku

Perlu diketahui bahwa definisi pengendalian intern COSO tidak berubah sejak dirilis. COSO awalnya menggunakan model tiga dimensi untuk menggambarkan sistem pengendalian intern dalam perusahaan. Gambar 3.1 menggambarkan model cOSO untuk pengendalian intern sebagai piramida dengan lima komponen yang saling berhubungan yang terdiri dari keseluruhan sistem pengendalian intern diantaranya

a. Lingkungan pengendalian yang berfungsi sebagai fondasi untuk seluruh struktur, empat komponen internal.

b. Penilaian Risiko, bertindak untuk mengidentifikasi resiko dan menentukan selera risiko yang memadai. 
c. Aktivitas pengendalian, pembentukan tanggung jawab, pemisahan tugas, prosedur dokumentasi, pengendalian secara fisik, verifikasi internal yang independen, pengendalian sumberdaya manusia

d. Komunikasi dan informasi, bertindak sebagai saluran antar muka untuk empat lapisan lainnya.

e. Monitoring, bertindak untuk meninjau dan memastikan ketaatan pada COSO

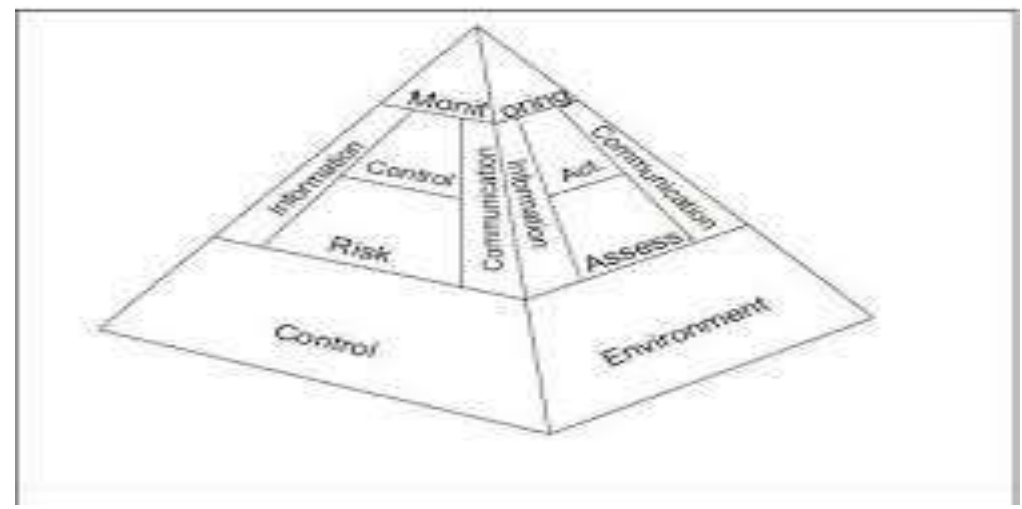

Gambar 3.1 Kerangka Pengendalian Internal COSO 1992

Sumber : (Moeller.R.R. 2016)

COSO merupakan suatu kerangka kerja yang memperlihatkan hubungan antara tujuan, komponen-komponen internal control, dan bentuk struktur dari organisasi yang melibatkan seluruh komponen yang ada di organisasi. Dimensi untuk ketaatan kepada COSO adalah Control Environment, Risk Assessment, Control Activities, Information and Communication serta Monitoring

Model COSO dengan cepat diadopsi oleh profesi audit dan akuntansi, Itu menjadi sangat penting setelah Sarbanes - Oxley Act (SOx) menjadi hukum. SOx mensyaratkan bahwa organisasi pelaporan publik harus membuktikan kecukupan pengendalian intern dengan menggunakan kerangka kerja COSO sebagai ukuran. 
COSO telah menerbitkan beberapa bahan panduan tambahan untuk mendukung dan mengklarifikasi kerangka kerja pengendalian internal. Dorongan umum dari kerangka kerja COSO yang telah direvisi adalah desain dan implementasi sistem pengendalian internal atas pelaporan keuangan untuk keperluan eksternal pada entitas publik, swasta, nirlaba, dan pemerintah, yang semuanya memiliki persyaratan pelaporan keuangan eksternal.

Audit internal dan manajemen perusahaan bertanggung jawab untuk memantau serta merancang dan menginstal proses pengendalian intern ini. Kerangka kerja pengendalian internal COSO sangat relevan, sehingga eksekutif bisnis, auditor internal, spesialis TI, staf keuangan dan akuntansi, dan yang lainnya harus mengetahui dan memahami kerangka kerja pengendalian internal coso. Semua harus fokus pada lima prinsip dasar yang mendukung pengendalian intern COSO perusahaan:

a. Organisasi harus menunjukkan komitmen terhadap integritas dan nilai-nilai etika.

b. Dewan direksi harus menunjukkan independensi dari manajemen dan melakukan pengendalian terhadap pengembangan dan kinerja pengendalian intern.

c. Manajemen harus menetapkan, dengan pengendalian dewan, struktur, jalur pelaporan, dan otoritas dan tanggung jawab yang tepat dalam mencapai tujuan.

d. Organisasi harus menunjukkan komitmen untuk, mengembangkan, dan mempertahankan individu yang kompeten sesuai dengan tujuan.

e. Suatu organisasi harus meminta pertanggungjawaban individu atas tanggung jawab pengendalian internal dalam mengejar tujuan. 


\section{B. Kerangka Kerja COSO dan Perubahan Lingkungan}

Konsep kerangka kerja COSO telah menjadi dasar bagi entitas yang menetapkan standar proses bisnis. Selain itu juga disahkan Sarbanas merupakan hukum federal Amerika Serikat yang ditetapkan pada 30 Juli 2002 sebagai tanggapan terhadap sejumlah skandal akuntansi perusahaan besar. Skandal-skandal yang menyebabkan kerugian bilyunan dolar bagi investor karena runtuhnya harga saham perusahaan-perusahaan yang terpengaruh skandal mengguncang kepercayaan masyarakat terhadap pasar saham USA. Sarbanas juga mengatur masalahmasalah seperti kebebasan auditor, tata kelola perusahaan, penilaian pengendalian internal, serta pengungkapan laporan keuangan yang lebih dikembangkan.

(Sarbanes, 2010) mengharuskan perusahaan untuk memiliki sistem pengendalian intern yang efektif dan konsisten dengan kerangka pengendalian intern COSO. Akibatnya, baik manajemen perusahaan dan auditor eksternal mereka berusaha untuk membangun kepatuhan dengan mengandalkan kerangka kerja COSO. Bagian organisasi di semua tingkatan, auditor internal, selalu mengingat konsep ini ketika membangun, menerapkan, dan memantau sistem dan proses pengendalian intern. Auditor internal harus menyadari bahwa semua program dan proses audit harus mencerminkan kerangka kerja coso. Kerangka kerja pengendalian internal coSO yang baru dan materi panduan pendukungnya mengandung perubahan dalam bidang-bidang berikut:

a. Ekspektasi yang diperluas untuk pengendalian tata kelola. Meningkatkan persyaratan peraturan dan harapan pemangku kepentingan perusahaan untuk meningkatkan 
penekanan pada kecukupan pengendalian keuangan internal.

b. Meningkatnya globalisasi pasar dan operasi. Perusahaan saat ini semakin berkembang di luar pasar domestik dalam mengejar nilai, masuk ke pasar internasional dan terlibat merger dan akuisisi lintas batas.

c. Perubahan dan kompleksitas yang lebih besar dalam operasi bisnis perusahaan. Perusahaan mengubah model bisnis dan melakukan transaksi yang kompleks dalam mengejar pertumbuhan, kualitas, produktivitas, serta sebagai respons terhadap perubahan di pasar.

d. Meningkatnya tuntutan dan kompleksitas dalam hukum, peraturan, regulasi, dan standar. Otoritas pemerintah semakin merilis peraturan dan perundang-undangan yang kompleks di mana kepatuhan seringkali sulit untuk dicapai dan di mana aturan-aturan ini tidak secara langsung mengikuti pendekatan pengendalian internal klasik.

e. Penggunaan dan ketergantungan yang terus meningkat pada teknologi yang berkembang. Perkembangan sistem $\mathrm{TI}$ dan teknologi terkait telah mengubah pendekatan untuk menerapkan dan mengelola proses pengendalian intern.

f. Meningkatnya kebutuhan untuk mencegah dan mendeteksi korupsi. Undang-Undang Praktik Korupsi Asing AS, yang diperkenalkan beberapa tahun yang lalu adalah contoh awal undang-undang untuk meningkatkan pengendalian intern dan persyaratan hukum lainnya. Saat ini, ada berbagai peraturan dan undang-undang anti korupsi dan antikecurangan yang berlaku. 


\section{Kerangka Kerja Pengendalian COSO}

Kerangka kerja COSO mendefinisikan pengendalian intern dari dua perspektif lain yaitu: komponen terpisah dari pengendalian intern dan faktor organisasi. Tampak serupa tetapi sedikit berbeda dari kerangka kendali internal COSO yang diperkenalkan pada tahun 1992, Gambar 3.2 menunjukkan kerangka pengendalian intern COSO tiga dimensi yang telah direvisi.

Tiga kategori operasi tujuan pengendalian internal, pelaporan, dan kepatuhan diwakili oleh kolom yang ditentukan di bagian atas dalam diagram ini. Sisi depan dari diagram kubus COSO ini mendefinisikan lima komponen utama pengendalian intern:

a. Lingkungan pengendalian

b. Penilaian risiko

c. Aktivitas pengendalian intern

d. Informasi dan komunikasi

e. Aktivitas pemantauan

Ditunjukkan di sisi kanan model, struktur organisasi perusahaan adalah dimensi penting ketiga dari pengendalian internal. Ini mewakili komponen terkait pengendalian intern dari struktur organisasi secara keseluruhan: entitas perusahaan itu sendiri, divisi, anak perusahaan, unit operasi, atau fungsi, termasuk proses bisnis seperti penjualan, pembelian, produksi, dan pemasaran. Sebagai poin kunci di sini, kita harus mengingat komponen entitas organisasi keseluruhan dimulai dengan keseluruhan atau total perusahaan dan kemudian merinci ke semua unit bisnis dan komponen individu juga. Beberapa aktivitas pengendalian individu mungkin berbeda satu sama lain dalam beberapa detail operasi, tetapi semuanya harus masuk ke dalam lingkungan pengendalian untuk entitas total. 


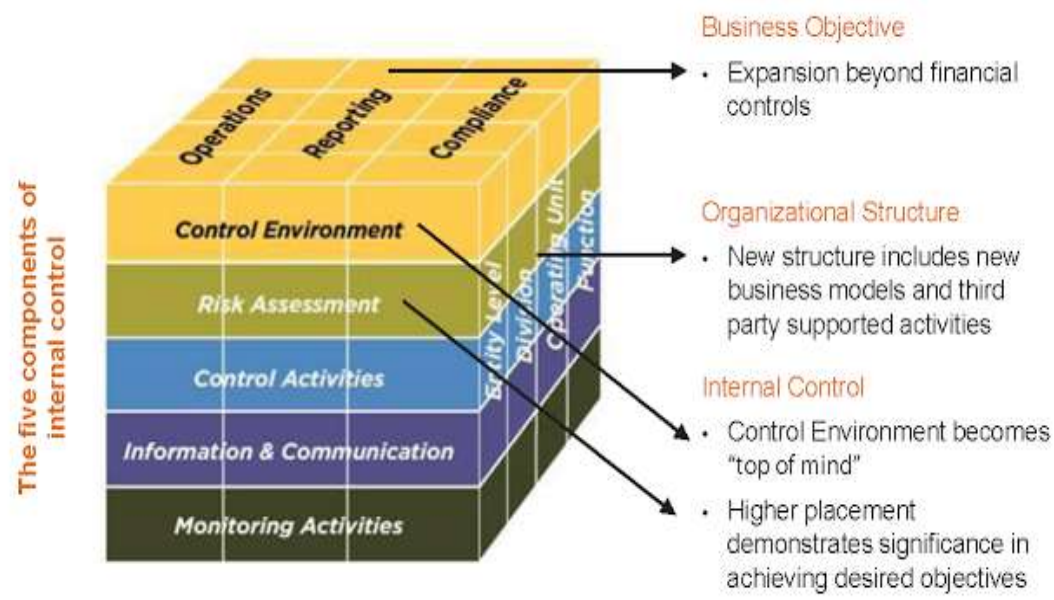

Gambar 3.2 Kerangka Pengendalian Internal COSO (Revisi 2013)

Sumber : (Moeller.R.R. 2016)

Seluruh ide di balik model ini adalah bahwa pengendalian intern untuk perusahaan saat ini bukan tujuan pengendalian tunggal tetapi konsep multilevel, beragam dengan masing-masing unit dalam model COSO yang memiliki hubungan dengan komponen lain di ketiga dimensi.

Manajemen perusahaan harus memahami dengan jelas tentang tujuan pengendalian internalnya, seperti menentukan tujuan pelaporan eksternal yang sesuai terkait dengan persyaratan laporan keuangan. Beberapa tujuan dapat sangat spesifik berdasarkan pada beberapa kegiatan bisnis yang direncanakan perusahaan. Manajemen juga harus menentukan sub-tujuan yang sesuai untuk divisi perusahaan, anak perusahaan, unit operasi, dan fungsi dengan kejelasan yang memadai untuk mendukung tujuan tingkat entitas. 


\section{Prinsip Pengendalian Internal coso}

Selain elemen tiga dimensi, kerangka kerja coso mengkodifikasikan seperangkat prinsip yang mendukung lima komponen pengendalian internal. Beberapa prinsip pengendalian intern inti, secara eksplisit menetapkan tujuh belas prinsip pengendalian intern yang mewakili konsep dasar yang terkait dengan 5 komponen pengendalian intern. COSO membuat prinsip-prinsip ini secara eksplisit untuk meningkatkan pemahaman manajemen tentang pengendalian intern yang efektif. Tujuh belas prinsip adalah konsep yang luas untuk diterapkan pada berbagai perusahaan, seperti nirlaba, perdagangan publik dan swasta, baik badan pemerintah maupun organisasi lainnya.

Menerapkan setiap prinsip COSO adalah titik focus untuk memberikan panduan untuk membantu manajemen dalam merancang, melaksanakan, dan melakukan proses pengendalian internal dan dalam menilai apakah prinsip-prinsip yang relevan ada dan berfungsi. Manajemen memiliki kebebasan untuk melakukan penilaian dalam menentukan relevansi dari titik-titik fokus yang disediakan dalam kerangka kerja coso dan dapat mengidentifikasi serta mempertimbangkan karakteristik penting lainnya sesuai dengan prinsip tertentu berdasarkan pada kondisi spesifik perusahaan.

Secara bersama-sama, komponen dan prinsip-prinsip COSO merupakan kriteria dan titik fokus yang akan membantu manajemen serta auditor internal dalam menilai apakah komponen-komponen pengendalian intern ini ada, berfungsi, dan beroperasi bersama dalam suatu perusahaan. Masing-masing titik fokus dipetakan langsung di atas tujuh belas prinsip, dan masing- 
masing juga dipetakan langsung ke salah satu dari lima komponen pengendalian intern.

Kunci bagi auditor internal untuk memahami kerangka kerja COSO adalah dengan mengingat sifat tiga dimensi kerangka kerja di mana setiap elemen pengendalian intern pada setiap sisi kubus COSO, harus dipertimbangkan dalam hal hubungannya dengan komponen lain ketika melakukan dan mengembangkan tinjauan audit internal.

\section{E. Komponen Pengendalian Internal COSO : Lingkungan Pengendalian}

Kategori tingkat atas komponen pengendalian COSO disebut lingkungan pengendalian merupakan seperangkat standar, proses, dan struktur yang memberikan dasar untuk melakukan kegiatan pengendalian internal yang efektif di seluruh perusahaan.

Lingkungan pengendalian mencakup tindakan dewan direksi dan manajemen senior yang bertanggung jawab atas keseluruhan pengendalian internal dan standar perilaku yang diharapkan. Lingkungan pengendalian terdiri dari nilai-nilai integritas dan etika perusahaan. Parameter yang memungkinkan dewan direksi untuk melaksanakan tanggung jawab pengendaliannya;

a. struktur organisasi dan penugasan wewenang dan tanggung jawab;

b. proses untuk menarik, mengembangkan, dan mempertahankan individu yang kompeten; dan indikator dalam ukuran kinerja, insentif, dan penghargaan untuk mendorong akuntabilitas atas kinerja.

Lingkungan pengendalian yang dihasilkan memiliki dampak luas pada keseluruhan sistem pengendalian internal. Komponen 
lingkungan pengendalian COSO dipengaruhi oleh berbagai faktor internal dan eksternal diantaranya;

a. sejarah entitas,

b. nilai-nilai entitas,

c. pasar,

d. lanskap kompetitif dan

e. peraturan.

Lingkungan pengendalian yang efektif menciptakan disiplin yang mendukung penilaian risiko yang diperlukan untuk pencapaian tujuan entitas, kinerja kegiatan pengendalian, penggunaan sistem informasi dan komunikasi, dan pelaksanaan kegiatan pemantauan. Ketika membangun lingkungan pengendalian perlu memperhatikan beberapa permasalahan diantaranya;

a. Perusahaan harus menentukan tujuan dengan kejelasan yang memadai untuk memungkinkan identifikasi dan penilaian risiko yang berkaitan dengan tujuan.

b. Perusahaan harus mengidentifikasi risiko terhadap pencapaian tujuannya di seluruh entitas dan menganalisis risiko sebagai dasar untuk menentukan bagaimana risiko harus dikelola.

c. Organisasi harus mempertimbangkan potensi kecurangan dalam menilai risiko dengan pencapaian tujuan.

d. Organisasi harus mengidentifikasi dan menilai perubahan yang secara signifikan berdampak pada sistem pengendalian internal.

Suatu perusahaan yang membangun dan memelihara lingkungan pengendalian yang kuat menempatkan dirinya untuk lebih tangguh dalam menghadapi tekanan internal dan eksternal yang selalu berubah. Hal ini dilakukan dengan menunjukkan; 
a. Perilaku integritas dan nilai-nilai etika.

b. Proses dan struktur pengendalian yang memadai, dan desain organisasi yang memungkinkan pencapaian tujuan entitas dengan penugasan otoritas dan tanggung jawab yang tepat,

c. Kompetensi tingkat tinggi, dan rasa akuntabilitas yang kuat untuk pencapaian tujuan. Baik dalam jangka pendek maupun jangka panjang, proses lingkungan pengendalian yang efektif harus memposisikan perusahaan dan elemenelemen kuncinya untuk menjadi lebih tangguh dalam menghadapi tekanan eksternal.

Lingkungan pengendalian perusahaan juga identik dengan budaya pengendalian intern. Elemen budaya yang kuat, seperti integritas dan nilai-nilai etika, pengendalian, akuntabilitas, dan evaluasi kinerja, menjadikan lingkungan pengendalian kuat. Budaya adalah bagian dari lingkungan pengendalian perusahaan, tetapi juga mencakup unsur-unsur komponen lain dari pengendalian intern, seperti menetapkan kebijakan dan prosedur yang efektif, kemudahan pengendalian keamanan atau akses ke informasi, dan responsif terhadap hasil kegiatan pemantauan. Auditor internal harus menyadari bahwa budaya organisasi dipengaruhi oleh lingkungan pengendalian yang telah ditetapkan serta komponen lain dari pengendalian intern.

Tujuan pengendalian internal menekankan bahwa manajemen senior, dewan direksi, atau badan pengawas harus memimpin dengan memberikan contoh dalam mengembangkan nilai-nilai, filosofi perusahaan, dan gaya operasi dalam mengejar tujuan perusahaan. Apa yang dilakukan dan dikatakan manajemen senior benar-benar mengirim pesan kepada semua orang yang terkait dengan perusahaan. Jika manajemen memberikan contoh yang 
tepat dan karyawan tahu bahwa nilai-nilai dan integritas etika manajemen, sikap itu akan diturunkan kepada karyawan dan bisnis akan memiliki fondasi yang kuat.

Kekuatan sistem apa pun didasarkan pada fondasi yang mendasarinya yaitu lingkungan pengendalian. Dasar dari sistem pengendalian adalah filosofi bisnis dan orang-orang yang mengendalikannya. Sebelum merancang pengendalian, seseorang harus mempertimbangkan fondasi lingkungannya.

Perusahaan dipimpin dari atas oleh manajemen senior dan dewan direksi, etika serta filosofi bisnis mereka akan diturunkan ke semua tingkat karyawan dan pemangku kepentingan. Semakin etis dan bertanggung jawab gaya manajemen, semakin besar kemungkinan karyawan akan merespons gaya itu dan berperilaku secara etis dan bertanggung jawab. Sebagai alternatif, jika manajemen menunjukkan sedikit kepedulian terhadap perilaku jujur dan etis, karyawan akan mengikuti arahan itu.

Lingkungan pengendalian kerangka kerja COSO dan prinsipprinsip pendukungnya adalah elemen kunci dan sangat penting untuk membangun pengendalian intern yang efektif dalam suatu perusahaan. Lingkungan pengendalian yang efektif mendukung dan memperkuat elemen pengendalian lainnya, sedangkan lingkungan pengendalian yang lemah merusak elemen-elemen ini, menjadikannya semua tidak berguna. Dalam lingkungan yang lemah, prosedur pengendalian dapat sering diabaikan dan memberikan peluang untuk kecurangan.

Lingkungan pengendalian perusahaan yang benar-benar lemah dapat merupakan tantangan besar bagi auditor internal. Auditor internal harus secara teratur menyoroti masalah ini dalam temuan dan rekomendasi laporan audit. Dalam kasus defisiensi total yang 
berkelanjutan, kepala audit internal perusahaan, kepala eksekutif audit, harus melaporkan masalah ini kepada dewan komite audit.

\section{F. Komponen Pengendalian Internal COSO: Menilai Risiko}

Penilaian risiko adalah elemen kunci dalam kerangka pengendalian intern COSO. Risiko didefinisikan sebagai kemungkinan suatu peristiwa dapat terjadi yang akan mempengaruhi pencapaian tujuan perusahaan. Pengelolaan risiko pengendalian internal mempengaruhi kemampuan perusahaan untuk berhasil, bersaing dalam industrinya, mempertahankan kekuatan keuangan dan reputasi positifnya, dan mempertahankan kualitas produk, layanan, dan orang-orangnya secara keseluruhan. Selalu ada beberapa risiko dalam aktivitas bisnis apa pun dan tidak ada cara praktis untuk mengurangi semuanya. Manajemen harus menentukan tingkat risiko yang harus diterima secara hati-hati dan berusaha untuk mempertahankan risiko dalam batas-batas yang diterima.

Komponen penilaian risiko pengendalian internal COSO adalah proses untuk menentukan bagaimana semua tingkat risiko akan dikelola, dan prasyarat untuk penilaian risiko adalah pembentukan tujuan terkait risiko, yang dikaitkan di berbagai tingkat operasi perusahaan. Karena jenis dan sifat risiko yang dihadapi perusahaan ada berbagai jenis, maka manajemen harus mengidentifikasi dan menentukan tujuan risiko perusahaan dalam kategori operasi, pelaporan, dan kepatuhan dengan kejelasan yang memadai agar dapat diidentifikasi dan dianalisis risiko terhadap tujuan perusahaan. Penilaian risiko juga mengharuskan manajemen untuk mempertimbangkan dampak dari kemungkinan perubahan di lingkungan eksternal yang dapat membuat pengendalian intern tidak efektif 
Auditor internal harus selalu mengingat masalah manajemen risiko ini dalam semua kegiatan audit pengendalian internal yang sedang berlangsung dengan empat konsep utama berikut:

a. Perusahaan harus menentukan tujuan dengan kejelasan yang memadai untuk memungkinkan identifikasi dan penilaian risiko yang berkaitan dengan tujuan perusahaan.

b. Perusahaan harus mengidentifikasi risiko terhadap pencapaian tujuannya di seluruh entitas dan harus menganalisis risiko sebagai dasar untuk menentukan bagaimana risiko tersebut harus dikelola.

c. Perusahaan harus mempertimbangkan potensi kecurangan dalam menilai risiko untuk pencapaian tujuan.

d. Perusahaan harus mengidentifikasi dan menilai perubahan yang secara signifikan dapat berdampak pada sistem pengendalian internnya.

Semakin kompleks aktivitas perusahaan, maka akan semakin banyak pula kemungkinan proses yang berisiko dan mengharuskan auditor internal memiliki knowledge dan keahlian untuk menerapkan teknik-teknik audit serta mampu mengenali indikator-indikator kecurangan dalam setiap produk maupun aktivitas bisnis perusahaan (Sarbanes, 2010a).

\section{Identifikasi dan Analisis Risiko.}

Manajemen perusahaan di semua tingkatan harus berusaha mengidentifikasi setiap risiko yang mungkin berdampak pada keberhasilan perusahaan, mulai dari risiko kecil di unit bisnis hingga risiko yang lebih besar yang berdampak pada keseluruhan bisnis. Ini membutuhkan pendekatan pemahaman dan pengetahuan spesifik untuk melihat potensi risiko di setiap area operasi dan kemudian mengidentifikasi area risiko yang 
lebih signifikan yang dapat mempengaruhi setiap operasi dalam periode waktu yang wajar.

Mengidentifikasi risiko yang mungkin berdampak pada operasi, dengan beberapa tingkat probabilitas, dalam periode waktu yang wajar. Identifikasi risiko bisa menjadi sulit karena kurang pemahaman terkait probabilitas risiko yang terjadi atau sifat konsekuensi jika perusahaan harus menghadapi risiko.

Proses identifikasi risiko harus terjadi pada berbagai tingkatan dalam suatu perusahaan. Risiko yang berdampak pada unit bisnis mungkin tidak memiliki dampak besar pada seluruh perusahaan, tetapi risiko utama yang berdampak pada seluruh perusahaan mengalir ke masing-masing unit bisnis yang terpisah.

Mengidentifikasi dan menganalisis risiko harus menjadi proses berulang yang berkelanjutan yang dilakukan untuk meningkatkan kemampuan perusahaan untuk mencapai tujuannya. Manajemen harus mempertimbangkan risiko di setiap tingkatan dan mengambil langkah-langkah yang diperlukan untuk mengelolanya. Penilaian risiko harus mempertimbangkan faktor-faktor yang mempengaruhi tingkat keparahan, kecepatan, dan kegigihan risiko, kemungkinan hilangnya aset, dan dampak terkait pada operasi, pelaporan, dan kegiatan kepatuhan. Selain itu, perusahaan perlu memahami toleransi untuk menerima risiko dan kemampuannya untuk beroperasi dalam tingkat risiko tersebut.

Begitu perusahaan telah melakukan identifikasi risiko awal, perusahaan harus mempertimbangkan semua interaksi terkait risiko yang signifikan termasuk barang, layanan, dan informasi internal perusahaan dan antara perusahaan dengan pihak 
eksternal terkait. Pihak eksternal tersebut dapat mencakup pemasok dan investor potensial, kreditor, pemegang saham, dan pemangku kepentingan lainnya serta pelanggan, perantara, dan pesaing. Selain itu, perusahaan harus mempertimbangkan masalah eksternal seperti undang-undang dan peraturan baru, masalah lingkungan, dan peristiwa alam yang potensial.

Gambar 3.3 mencantumkan beberapa area risiko utama yang dapat berdampak pada perusahaan, termasuk risiko strategis, operasi, dan keuangan.

Proses identifikasi risiko harus berusaha mempertimbangkan semua risiko dalam suatu perusahaan, termasuk subunit dan fungsi operasionalnya, seperti keuangan, sumber daya manusia, pemasaran, produksi, pembelian, dan manajemen TI. Selain itu, proses identifikasi risiko harus mempertimbangkan risiko yang berasal dari penyedia layanan outsourcing, pemasok utama, dan mitra penyalur yang secara langsung atau tidak langsung berdampak pada pencapaian tujuan perusahaan.

\section{Strategi Merespon Risiko.}

Sebagai bagian dari membangun pengendalian intern COSO yang efektif, perusahaan juga harus mengembangkan strategi pengelolaan risiko untuk mengatasi bagaimana menilai, merespons, dan memantau risiko. Merespon risiko sering melibatkan penilaian berdasarkan asumsi tentang risiko dan analisis yang wajar dari biaya yang terkait dengan pengurangan tingkat risiko. Materi panduan pengendalian internal coso mengidentifikasi empat pendekatan strategi merespon risiko dasar: 


\begin{tabular}{|c|c|c|c|}
\hline \multicolumn{4}{|c|}{ Risiko Strategis } \\
\hline \multicolumn{2}{|c|}{ Risiko Faktor Eksternal } & \multicolumn{2}{|c|}{ Risiko Faktor Internal } \\
\hline \multicolumn{2}{|c|}{$\begin{array}{l}\text { 1. Risiko Industri } \\
\text { 2. Risiko Ekonomi } \\
\text { 3. Risiko Pesaing } \\
\text { 4. Risiko Perubahan Hukum dan } \\
\text { Peraturan } \\
\text { 5. Risiko Kebutuhan dan } \\
\text { Keinginan Pelanggan }\end{array}$} & \multicolumn{2}{|c|}{$\begin{array}{l}\text { 1. Risiko Reputasi } \\
\text { 2. Risiko Fokus Strategis } \\
\text { 3. Risiko Dukungan Induk } \\
\text { Perusahaan } \\
\text { 4. Risiko Perlindungan } \\
\text { Paten. Merek Dagang }\end{array}$} \\
\hline \multicolumn{4}{|c|}{ Risiko Operasional } \\
\hline Risiko Proses & \multicolumn{2}{|c|}{ Risiko Kepatuhan } & Risiko Manusia \\
\hline $\begin{array}{l}\text { 1. Risiko Rantai } \\
\text { Pasokan } \\
\text { 2. Risiko Kepuasan } \\
\text { Pelanggan } \\
\text { 3. Risiko Siklus Waktu } \\
\text { 4. Proses Risiko } \\
\text { Eksekusi }\end{array}$ & \multicolumn{2}{|c|}{$\begin{array}{ll}\text { 1. } & \text { Risiko } \\
\text { Lingkungan } \\
\text { 2. Risiko Regulasi } \\
\text { 3. Risiko } \\
\text { Kebijakan dan } \\
\text { Prosedur } \\
\text { 4. Risiko Litigasi }\end{array}$} & $\begin{array}{l}\text { 1. Risiko Sumber } \\
\text { Daya Manusia } \\
\text { 2. Risiko Perputaran } \\
\text { Karyawan } \\
\text { 3. Risiko Insentif } \\
\text { Kinerja } \\
\text { 4. Risiko Pelatihan }\end{array}$ \\
\hline \multicolumn{4}{|c|}{ Risiko Keuangan } \\
\hline Risiko Treasury & \multicolumn{2}{|c|}{ Risiko Kredit } & Risiko Perdagangan \\
\hline $\begin{array}{l}\text { 1. Risiko Suku Bunga } \\
\text { 2. Risiko Nilai Tukar } \\
\text { 3. Risiko Ketersediaan } \\
\text { Modal }\end{array}$ & \multicolumn{2}{|c|}{$\begin{array}{l}\text { 1. Risiko Kapasitas } \\
\text { 2. Risiko Agunan } \\
\text { 3. Risiko } \\
\text { Konsentrasi } \\
\text { 4. Risiko Default } \\
\text { 5. Risiko } \\
\text { penyelesaian } \\
\end{array}$} & $\begin{array}{l}\text { 1. Risiko Harga } \\
\text { Komoditas } \\
\text { 2. Risiko Durasi } \\
\text { 3. Risiko } \\
\text { Pengukuran }\end{array}$ \\
\hline \multicolumn{4}{|c|}{ Risiko Informasi } \\
\hline Risiko Keuangan & \multicolumn{2}{|c|}{$\begin{array}{c}\text { Risiko } \\
\text { Operasional }\end{array}$} & Risiko Teknologi \\
\hline $\begin{array}{l}\text { 1. Risiko Standar } \\
\text { Akuntansi } \\
\text { 2. Risiko Penganggaran }\end{array}$ & \multicolumn{2}{|c|}{ 1. Risiko Harga } & $\begin{array}{l}\text { 1. Risiko Akses } \\
\text { Informasi }\end{array}$ \\
\hline
\end{tabular}




\begin{tabular}{|l|l|l|}
\hline $\begin{array}{l}\text { 3. Risiko Pelaporan } \\
\text { Keuangan }\end{array}$ & $\begin{array}{l}\text { 2. Risiko } \\
\text { Pengukuran }\end{array}$ & 2. Risiko Kontinuitas \\
Bisnis \\
$\begin{array}{ll}\text { 4. Risiko Perpajakan } \\
\text { 5. Ris Pelaporan }\end{array}$ & Kinerja & 3. Risiko \\
Regulasi & $\begin{array}{l}\text { 3. Risiko } \\
\text { Keselamatan }\end{array}$ & Ketersediaan \\
& Karyawan & $\begin{array}{l}\text { Risiko } \\
\text { Infrastruktur }\end{array}$ \\
\hline
\end{tabular}

Ganbar 3.3 Jenis Risiko Bisnis Perusahaan

Sumber : (Moeller.R.R. 2016)

a. Penghindaran risiko. Ini adalah strategi untuk menjauh dari risiko.

b. Pengurangan risiko. Berbagai macam keputusan bisnis mungkin dapat mengurangi risiko tertentu.

c. Berbagi risiko. Sebagian besar perusahaan melakukan lindung nilai atau berbagi sebagian dari risiko mereka dengan membeli asuransi.

d. Menerima risiko. Ini adalah strategi tanpa tindakan. Untuk banyak dan beragam risiko yang mendekati suatu perusahaan, penerimaan seringkali merupakan strategi yang tepat untuk beberapa risiko.

Keempat strategi umum tersebut adalah konsep kunci dalam memahami manajemen risiko, dan auditor internal harus mengembangkan strategi respons umum untuk masing-masing risiko dengan menggunakan pendekatan yang dibangun di dari salah satunya. Dalam melakukannya, mempertimbangkan biaya versus manfaat dari respons risiko potensial.

\section{G. Komponen Pengendalian Internal COSO: Aktivitas Pengendalian Internal.}

Kegiatan pengendalian adalah tindakan yang ditetapkan melalui kebijakan dan prosedur yang membantu memastikan bahwa arahan manajemen untuk memitigasi risiko terhadap pencapaian tujuan telah dilaksanakan. Kegiatan pengendalian 
dilakukan di semua tingkat perusahaan, pada berbagai tahap dalam unit dan proses bisnis, dan di lingkungan teknologi. Aktivitas pengendalian ini mungkin bersifat preventif atau detektif dan dapat mencakup serangkaian aktivitas manual dan otomatis seperti otorisasi dan persetujuan, verifikasi, rekonsiliasi, dan tinjauan kinerja bisnis.

Pengendalian intern mendasar, seperti pemisahan tugas biasanya dibangun untuk pengembangan kegiatan pengendalian COSO. Jika pemisahan tugas pengendalian internal tidak efektif manajemen harus memilih dan mengembangkan kegiatan pengendalian alternatif. Pemisahan tugas adalah konsep pengendalian internal dasar yang penting di banyak bidang. Aktivitas pengendalian mendukung semua komponen pengendalian intern COSO, dan panduan kerangka kerja pengendalian intern coso lebih menyelaraskan aktivitas pengendalian dengan elemen penilaian risiko.

Seiring dengan penilaian risiko, manajemen harus mengidentifikasi dan menerapkan tindakan yang diperlukan ketika perusahaan memilih untuk menerima atau menghindari risiko. Sifat dan sejauh mana respons risiko dan kegiatan pengendalian terkait akan bergantung pada tingkat mitigasi risiko yang diinginkan oleh manajemen perusahaan. Dengan mitigasi dan melakukan beberapa tindakan untuk mengurangi paparan terhadap risiko yang diidentifikasi atau kemungkinan terjadinya.

Aktivitas pengendalian mencakup tindakan yang memastikan bahwa respons terhadap risiko yang dinilai dan arahan manajemen dilakukan dengan benar dan tepat waktu. Ketika menentukan tindakan yang direkomendasikan diambil untuk mengurangi risiko, auditor internal harus mempertimbangkan semua aspek dari sistem pengendalian internal perusahaan serta 
proses bisnis yang relevan dan lokasi di mana kegiatan pengendalian diperlukan.

\section{Aktivitas Pengendalian Proses Bisnis}

Proses bisnis adalah suatu kumpulan aktivitas atau pekerjaan terstruktur yang saling terkait untuk menyelesaikan suatu masalah tertentu atau yang menghasilkan produk atau layanan demi meraih tujuan tertentu. Suatu proses bisnis dapat dipecah menjadi beberapa subproses yang masing-masing memiliki atribut sendiri tetapi juga berkontribusi untuk mencapai tujuan dari prosesnya. Analisis proses bisnis umumnya melibatkan pemetaan proses dan subproses di dalamnya hingga tingkatan aktivitas atau kegiatan (AICPA, 2016).

Pengendalian transaksi sering kali merupakan aktivitas pengendalian paling mendasar dalam suatu perusahaan karena pengendalian transaksi secara langsung menangani respons risiko terhadap proses bisnis yang ada untuk memenuhi tujuan manajemen. Pengendalian transaksi harus dipilih dan dikembangkan di mana pun proses bisnis berada, mulai dari proses konsolidasi keuangan perusahaan yang terpusat hingga proses dukungan pelanggan di unit operasi lokal.

Proses bisnis yang khas akan mencakup banyak tujuan dan sub-tujuan, masing-masing dengan serangkaian risiko dan respons risiko sendiri. Cara umum untuk mengkonsolidasikan risiko proses bisnis ini ke dalam bentuk yang dapat dikelola adalah dengan mengelompokkannya sesuai dengan tujuan kelengkapan, akurasi, dan ketersediaan proses bisnis. Jika tujuan tercapai untuk masing-masing transaksi dalam proses bisnis tertentu, maka sub-tujuan proses bisnis kemungkinan akan tercapai. 
Elemen kegiatan pengendalian dari kerangka kerja COSO menggunakan tujuan pemrosesan informasi berikut:

a. Kelengkapan. Transaksi yang terjadi harus dicatat.

b. Akurasi. Transaksi harus dicatat dalam jumlah yang benar di akun yang tepat dan tepat waktu.

c. Validitas. Validitas umumnya dicapai melalui kegiatan pengendalian yang mencakup otorisasi transaksi sebagaimana ditentukan oleh kebijakan dan prosedur perusahaan.

Membatasi akses pemrosesan TI merupakan bentuk pengendalian intern, karena tanpa membatasi akses pada transaksi dalam proses bisnis dapat menyebabkan pengendalian tidak dapat dicapai karena tujuan TI paling sering dikaitkan dengan proses keuangan dan transaksi, sehingga konsep membatasi akses tersebut dapat diterapkan pada aktivitas perusahaan apapun.

Tujuan pemrosesan TI dan kegiatan pengendalian berlaku juga untuk proses pengambilan keputusan manajemen atas penilaian dan perkiraan kritis. Dalam pengambilan keputusan, manajemen harus mempertimbangkan kelengkapan identifikasi faktor-faktor penting yang mempengaruhi estimasi harus dikembangkan dan mendukung asumsi-asumsi dalam pengambilan keputusan. Demikian pula, manajemen harus mempertimbangkan validitas dan kewajaran asumsi-asumsi tersebut dan keakuratan model estimasi tersebut.

\section{Jenis Aktivitas Pengendalian Transaksi.}

Materi panduan kerangka kerja pengendalian internal COSO menyoroti jenis-jenis kegiatan pengendalian transaksi berikut ini: 
a. Verifikasi. Ini adalah jenis pengendalian transaksi yang membandingkan dua item atau lebih satu sama lain atau membandingkan item dengan aturan kebijakan, dan melakukan tindakan tindak lanjut ketika item yang dibandingkan tidak cocok atau dianggap tidak konsisten dengan kebijakan.

b. Rekonsiliasi. Proses transaksi ini membandingkan dua atau lebih elemen data, dan jika perbedaan diidentifikasi, tindakan diambil untuk membawa data ke dalam perjanjian. Rekonsiliasi umumnya membahas kelengkapan dan akurasi pemrosesan transaksi.

c. Otorisasi dan persetujuan. Otorisasi merupakan persetujuan oleh tingkat manajemen yang lebih tinggi atau verifikasi yang dihasilkan sistem dan penentuan bahwa suatu transaksi valid.

d. Pengendalian fisik. Inventaris peralatan, sekuritas, uang tunai, dan aset lainnya biasanya dijamin secara fisik di area penyimpanan yang terkunci atau dijaga. Transaksi pengendalian fisik di sini harus dihitung dan dibandingkan secara berkala dengan catatan pengendalian pendukung.

e. Pengendalian atas data tegakan. Adalah elemen data yang dikembangkan dari luar perusahaan (seringkali dari organisasi standar, IAI,) yang mendukung pemrosesan transaksi di dalam perusahaan.

f. Pengendalian. Proses pengendalian transaksi ini menilai apakah aktivitas pengendalian transaksi lainnya, seperti verifikasi, persetujuan, pengendalian atas data tegakan, dan aktivitas pengendalian fisik sedang dilakukan dengan lengkap, akurat, dan sesuai dengan kebijakan dan prosedur perusahaan. 
H. Komponen Pengendalian Internal: Informasi dan Kommunikasi

Informasi diperlukan perusahaan untuk melaksanakan tanggung jawab pengendalian internalnya untuk mendukung pencapaian tujuannya. Manajemen menyusun dan kemudian menggunakan informasi yang relevan dan berkualitas dari sumber internal dan eksternal untuk mendukung berfungsinya komponen-komponen pengendalian intern. Selanjutnya auditor internal meninjau dan menilai informasi manajemen yang sama untuk memastikan bahwa informasi telah dikelola dengan tepat waktu.

Komunikasi, didefinisikan di sini sebagai proses berulangulang untuk menyediakan, berbagi, dan memperoleh informasi yang diperlukan. Komunikasi internal adalah cara penyebaran informasi di seluruh perusahaan, mengalir naik, turun, dan melintasi entitas. Ini memungkinkan personel untuk menerima pesan yang jelas dari manajemen senior bahwa tanggung jawab pengendalian harus ditanggapi dengan serius.

Selain itu, konsep informasi dan komunikasi telah berubah di dunia saat ini menggunakan praktik-praktik seperti penyedia layanan outsourcing dalam ekonomi global berbasis internet. Elemen informasi dan komunikasi COSO adalah komponen kunci untuk mengembangkan dan menerapkan proses pengendalian intern yang efektif. Konsep keseluruhan yang mendukung informasi dan komunikasi COSO adalah bahwa suatu perusahaan perlu mengembangkan dan memberikan berbagai bentuk dan jenis informasi yang kompeten, dari dan ke manajemen. Artinya, proses harus ada untuk mengidentifikasi, menangkap, dan mendistribusikan elemen-elemen kunci dari semua jenis informasi dan kemudian mengomunikasikan elemen-elemen 
yang relevan dari informasi ini kepada pihak-pihak yang tepat. Proses informasi dan komunikasi ini harus:

a. Catat transaksi saat itu terjadi, membaginya menjadi bagian-bagian komponen mereka (tanggal, jumlah, nama, akun, otorisasi, dll).

b. Memproses, meringkas, dan melaporkan informasi itu untuk tujuan manajemen dan tujuan akuntansi murni.

c. Menyimpan data yang diambil dan diproses dalam format yang dapat diringkas, diaudit, ditinjau, dan dilaporkan dengan cepat dan mudah.

d. Laporkan informasi itu dalam format yang dapat digunakan untuk analisis manajemen dan tujuan pengendalian internal.

Kerangka kerja pengendalian internal cosO mendefinisikannya informasi dalam arti yang lebih luas yaitu informasi mencakup semua data yang digabungkan dan dirangkum berdasarkan relevansinya dengan persyaratan informasi perusahaan.

Komponen elemen komunikasi COSO meminta perusahaan untuk membagikan informasi yang relevan dan berkualitas secara internal dan eksternal. Manajemen mengkomunikasikan informasi secara internal agar personelnya dapat lebih memahami tujuan perusahaan dan pentingnya tanggung jawab pengendalian mereka. Komunikasi internal memfasilitasi berfungsinya komponen-komponen lain dari pengendalian intern diseluruh perusahaan.

Komunikasi eksternal memungkinkan manajemen untuk mendapatkan dan berbagi informasi antara perusahaan dan pihak eksternal tentang risiko, masalah peraturan, dan perubahan keadaan, kepuasan pelanggan, dan informasi lain 
yang relevan dengan berfungsinya komponen pengendalian intern lainnya.

\section{Pentingnya Menggunakan Informasi yang Relevan}

Informasi relevan berarti informasi tersebut memiliki manfaat untuk pemakainya. Relevansi informasi untuk satu perusahaan ke perusahaan yang lainnya berbeda. Dengan massa informasi, seperti sistem dan prosedur, memo, komunikasi email ganda, posting berita vendor eksternal, dan komunikasi dari sumber media sosial.

Auditor internal sering dibombardir dengan informasi ketika mulai meninjau dan menilai pengendalian intern. Auditor internal harus mendapatkan dan menggunakan informasi yang relevan dan berkualitas untuk mendukung berfungsinya komponen-komponen pengendalian internal yang sedang ditinjau. Informasi tentang tujuan tingkat tinggi perusahaan harus dikumpulkan dari dewan direksi dan kegiatan manajemen senior dan diringkas sedemikian rupa sehingga manajemen lini dan pihak lain dapat memahami tujuan dan peran mereka dalam pencapaian perusahaan.

Untuk memperoleh informasi yang relevan, mengharuskan manajemen untuk mengidentifikasi dan menetapkan persyaratan informasi pada tingkat detail. Mengidentifikasi persyaratan informasi adalah proses berulang dan berkelanjutan yang terjadi sepanjang kinerja sistem pengendalian intern yang efektif.

Persyaratan informasi ditetapkan melalui kegiatan yang dilakukan untuk mendukung komponen pengendalian intern lainnya. Persyaratan ini mengarahkan manajemen dan personel lain untuk mengidentifikasi sumber informasi yang relevan dan dapat diandalkan serta data yang mendasarinya. 
Jumlah informasi dan data dasar yang tersedia untuk manajemen sering kali lebih dari yang dibutuhkan karena meningkatnya sumber informasi dan kemajuan dalam pengumpulan, pemrosesan, dan penyimpanan data. Dalam kasus lain, data mungkin sulit diperoleh pada tingkat yang relevan. Oleh karena itu, pemahaman yang jelas tentang persyaratan informasi yang dikeluarkan COSO mengarahkan manajemen dan personel lain untuk mengidentifikasi sumber informasi dan data yang relevan dan dapat diandalkan.

\section{Pentingnya Komunikasi Internal}

COSO menyarankan bahwa suatu perusahaan harus mengomunikasikan tujuan dan tanggung jawab pengendalian internal yang baik secara internal. Komunikasi yang terkait dengan informasi ini harus diprakarsai dan didukung oleh manajemen senior dan disampaikan kepada semua elemen di seluruh organisasi perusahaan, termasuk:

a. Pentingnya, relevansi, dan manfaat dari pengendalian intern yang efektif

b. Peran dan tanggung jawab manajemen dan personel lain dalam melakukan proses pengendalian intern tersebut

c. Harapan perusahaan untuk berkomunikasi di semua hal penting yang berkaitan dengan pengendalian intern, termasuk contoh kelemahan, kemunduran, atau ketidakpatuhan.

Perusahaan harus menetapkan kebijakan dan prosedur yang memfasilitasi komunikasi internal yang efektif. Manajemen senior harus mengomunikasikan tujuan perusahaan dengan jelas sehingga manajemen dan personel lain, termasuk kontraktor, memahami peran mereka dalam 
organisasi. Komunikasi internal dimulai dengan komunikasi tujuan. Ketika manajemen membuat komunikasi tujuan perusahaan, penting bahwa sub-tujuan terkait dikomunikasikan kepada personel dengan cara yang memungkinkan mereka untuk memahami peran dan tanggung jawab mereka terhadap pencapaian tujuan perusahaan. Auditor internal harus mengingat kebutuhan ini ketika melakukan tinjauan pengendalian internal.

Selain itu, informasi yang dibagikan melalui komunikasi internal membantu manajemen dan personel lain untuk mengenali masalah atau potensi masalah, untuk menentukan penyebabnya, dan untuk mengambil tindakan korektif.

Komunikasi antara manajemen senior dan dewan direksi memberikan informasi yang dibutuhkan dewan untuk melaksanakan tanggung jawab pengawasannya untuk pengendalian internal. Informasi yang berkaitan dengan pengendalian intern yang dikomunikasikan kepada dewan umumnya harus mencakup tentang kepatuhan, perubahan, atau masalah yang timbul dari sistem pengendalian intern. Frekuensi dan tingkat perincian komunikasi kepada manajemen dan dewan direksi harus memadai untuk memungkinkan pihak-pihak ini memahami hasil penilaian yang terpisah dan berkelanjutan oleh manajemen dan dampak dari hasil tersebut terhadap pencapaian tujuan.

Panduan pengendalian intern coso mendorong komunikasi langsung antara anggota dewan dan personil lainnya. Anggota dewan direksi harus memiliki akses langsung ke karyawan tanpa melalui manajemen senior. Ini adalah jenis panduan yang terdengar baik dalam teori tetapi seringkali tidak terlalu efektif dalam praktik. 
I. Komponen Pengendalian Internal COSO: Aktivitas Pemantauan.

Kegiatan pemantauan menilai apakah masing-masing dari lima komponen pengendalian intern COSO, yaitu lingkungan pengendalian, penilaian risiko, dan lainnya, ada dan berfungsi. Perusahaan dan auditor internal harus menggunakan proses evaluasi yang sedang berlangsung dan terpisah untuk memastikan apakah prinsip-prinsip pengendalian internal yang ditetapkan, baik lintas perusahaan dan sub-unitnya, berlaku, ada, dan berfungsi. Pemantauan di sini adalah input utama ke dalam penilaian organisasi tentang efektivitas pengendalian internal. Kerangka kerja pengendalian internal COSO mengidentifikasi dua prinsip untuk komponen pengendalian intern kegiatan pemantauan:

a. Organisasi memilih, mengembangkan, dan melakukan evaluasi yang sedang berlangsung dan terpisah untuk memastikan apakah komponen-komponen pengendalian internal ada dan berfungsi.

b. Organisasi mengevaluasi dan mengomunikasikan kekurangan pengendalian intern tepat waktu kepada pihakpihak yang bertanggung jawab untuk mengambil tindakan korektif, termasuk manajemen senior dan dewan direksi, sebagaimana diperlukan.

Sistem pengendalian intern suatu perusahaan dapat berubah, dan tujuan entitas serta komponen-komponen pengendalian internnya dapat berubah dari waktu ke waktu. Sehingga prosedur dapat menjadi kurang efektif, dan tidak berfungsi, atau mungkin dianggap tidak memadai untuk mendukung pencapaian tujuan pengendalian intern yang baru. 
Kegiatan pemantauan harus dipilih, dikembangkan, dan dilakukan untuk memastikan apakah masing-masing komponen pengendalian intern ada dan berfungsi. Manajemen juga perlu menentukan apakah sistem pengendalian internal terus relevan dan mampu mengatasi risiko baru.

Apabila diperlukan, kegiatan pemantauan mengidentifikasi dan memeriksa kesenjangan harapan dengan anomali dan abnormalitas pengendalian intern yang terjadi, yang menyebabkan satu atau lebih komponen pengendalian intern, di seluruh perusahaan dan sub-unitnya tidak berfungsi. Kegiatan pemantauan umumnya akan mengidentifikasi akar penyebab gangguan tersebut.

Perusahaan perlu mempertimbangkan rincian mendasar dalam menentukan apakah suatu kegiatan merupakan kegiatan pengendalian atau kegiatan pemantauan. Suatu kegiatan pengendalian merespons risiko tertentu, sedangkan kegiatan pemantauan menilai apakah pengendalian di dalam masingmasing lima komponen pengendalian internal beroperasi sebagaimana dimaksud. Seperti biasa, ketika mempertimbangkan aspek pengendalian intern COSO, harus selalu mempertim bangkan sifat tiga dimensi dari kerangka kerja coso dan mengontrol hubungan naik, turun, dan lintas.

Tinjauan audit internal atas beberapa area operasi atau pengendalian intern adalah contoh kegiatan pemantauan terpisah dan alasan mengapa proses audit internal sangat penting untuk membangun pengendalian intern yang efektif di bawah kerangka kerja COSO. Melakukan audit internal yang efektif, tinjauan pengendalian internal sebaiknya direncanakan dan dijadwalkan berdasarkan proses penilaian risiko. 
Pengendalian yang tidak dipantau cenderung memburuk seiring waktu. Kerangka kerja COSO mendefinisikan pemantauan sebagai proses untuk membantu memastikan bahwa pengendalian intern terus beroperasi secara efektif. Ketika pemantauan dirancang dan dilaksanakan dengan tepat, suatu perusahaan harus mendapatkan manfaat karena lebih cenderung untuk:

a. Identifikasi dan koreksi masalah pengendalian intern tepat waktu

b. Menghasilkan informasi yang lebih akurat dan andal untuk digunakan dalam pengambilan keputusan

c. Menyiapkan laporan keuangan yang akurat dan tepat waktu

d. Berada dalam posisi untuk memberikan sertifikasi atau pernyataan berkala tentang efektivitas pengendalian internal (The Institute of Auditor internal s, 2016)

Proses pemantauan yang efektif adalah komponen utama untuk memastikan bahwa perusahaan memiliki pengendalian intern yang efektif dan audit internal memiliki tanggung jawab utama dalam membantu melakukan banyak proses pemantauan.

\section{J. Simpulan}

Normalnya, perusahaan yang sudah establish dan menggunakan pengalamannya akan semakin baik mengelola operasional dan bisnisnya. Proses manajemen risiko akan semakin mature dan seluruh risiko utama yang bisa mengganggu penjualan produknya akan diidentifikasi dengan baik, termasuk fraud risk.

Internal auditor juga diharapkan memahami desain kontrol dan risiko-risiko yang ada beserta severity dari risiko-risiko tersebut. Disamping itu, internal auditor juga harus mampu mengevaluasi kontrol yang ada, apakah sudah cukup untuk 
memitigasi kemungkinan adanya fraud baik external fraud maupun internal fraud.

Banyak kejadian-kejadian dimana terjadi fraud yang seolaholah dilakukan oleh pelakunya (baik pelaku eksternal maupun internal, atau berkolaborasi eksternal-internal atau kebobolan), dengan cara yang canggih. Ternyata, setelah diteliti, caranya tidak rumit. Kebanyakan hanya masalah sepele dan tidak komit terhadap mekanisme dan prosedur yang ada atau sudah ditetapkan.

Memang, ada juga beberapa kekurangan dari SOP atau Juklak yang berkontribusi sehingga dalam operasional menjadi lengah dan bahkan menjadi celah masuknya fraud, terutama fraud eksternal. Banyak hal yang membuat fraud bisa terjadi. Sebagaimana kita ketahui bahwa ada tiga faktor yang mendorong terjadinya fraud, yakni: pressure atau incentive, opportunity dan rationalization.

K. Contoh Kasus Fraud Auditor the Committee of Sponsoring Organizations ofthe Treadway Commission (COSO)

Pada penelitian terbaru yang dilakukan oleh coso terkait kecurangan dalam pelaporan keuangan oleh perusahaanperusahaan publik di Amerika Serikat memberikan konsekuensi negatif yang signifikan terhadap para investor dan eksekutif.

Penelitian COSO tersebut, dengan menelaah tuduhan kecurangan laporan keuangan yang diselidiki oleh Securities and Exchange Commission (SEC) dalam kurun waktu sepuluh tahun antara tahun 1998 - 2007, menemukan fakta bahwa berita dugaan kecurangan telah mengakibatkan penurunan abnormal harga saham rata-rata $16,7 \%$ dalam dua hari setelah diumumkan. Perusahaan-perusahaan yang terlibat dalam kecurangan seringkali mengalami kebangkrutan, delisting dari bursa efek, atau 
harus menjual aset, dan sembilan dari sepuluh kasus-kasus SEC tersebut menyebutkan CEO dan/atau CFO perusahaan yang bersangkutan diduga terlibat dalam kecurangan.

\section{Solusi}

Semua pihak yang terlibat dalam proses pelaporan keuangan harus terus berfokus pada cara-cara untuk mencegah, menghalangi, dan mendeteksi kecurangan pelaporan keuangan.

\section{Pertanyaan untuk didiskusikan}

1. Apa yang anda ketahui tentang pengendalian intern ?

2. Apa yang anda pahami tentang kerangka kerja COSO?

3. Jelaskan komponen pengendalian intern COSO terkait dengan lingkungan pengendalian!

4. Berikan contoh komponen pengendalian intern COSO terkait dengan penilaian risiko!

5. Menurut pendapat anda apa manfaat memahami pengendalian internal COSO terkait aktivitas pengendalian

\section{Soal kasus}

Berdasarkan kasus dibawah ini anda diminta memberikan solusi apa sebaiknya yangn diterapkan oleh tim audit internal dan hubungkan solusi tersebut dengan kerangka pengendallian COSO.

PT Gopas, Tbk dan anak perusahaan yang merupakan kelompok usaha yang bergerak dalam bidang jasa pengiriman barang dan dokumen serta surat keseluruh penjuru dunia. PT Gopas Tbk dan anak perusahaan memiliki armada pengiriman 8 buah Pesawat Terbang Cargo, 6 Kapal tanker, 8 Kapal untuk pengiriman barang umum, dan armada darat yang beroperasi diseluruh penjuru dunia sebanyak kurang lebih 750 buah. Dengan mengacu pada visi perusahaan sebagai perusahaan pengiriman barang dan dokumen tercepat dan terpercaya, manajemen PT Gopas, Tbk mempekerjakan grup internal audit dengan tugas utama untuk melakukan analisa dan evaluasi, memberikan keyakinan dan rekomendasi, serta informasi lain kepada 
manajemen dan dewan komisaris, atau pihak lain yang setara wewenang dan tanggung jawabnya. Selain tugas utama tersebut, grup internal audit juga mempunyai tugas sebagai partner bisnis manajemen yang diharuskan untuk memberikan rekomendasi kepada manajemen dalam melakukan melakukan pengambilan keputusan yang bersifat strategis. Tugas dan fungsi internal audit tersebut telah dituangkan dalam Grup piagam internal audit. Grup internal audit tersebut bertanggung jawab kepada Komite Audit PT Gopas, Tbk. Untuk mencapai tujuan piagam audit tersebut, grup internal audit memiliki 90 personel audit yang tersebar diseluruh dunia dan dikepalai oleh Laili, CPA. Pekerjaan yang akan dilakukan oleh grup internal audit sepanjang tahun 2020 adalah sebagai berikut:

a. Melakukan pengujian terhadap ketaatan atas kebijakan, prosedur dan pengendalian grup perusahaan.

b. Melakukan pengujian substantif untuk akun-akun yang besifat material, antara lain, pendapatan, beban, piutang, hutang usaha, aktiva tetap;

Melakukan pengujian atas ketaatan terhadap kontrak dan perjanjian, serta undangundang dan peraturan yang berlaku bagi PT Gopas, Tbk, termasuk perjanjian pinjaman, perjanjian dengan pelanggan, pemasok, ketaatan terhadap peraturan perpajakan.

\section{Daftar Pustaka}

Moeller.R.R. (2016). Brink's Modern Internal Auditing Eighth Edition A Common Body of Knowledge Published by John Wiley \& Sons, Inc., Hoboken, New Jersey.

AICPA. (2016). The American Institute of Certified Public Accountants (AICPA). About the AICPA dapat diunduh www.aicpa.org >

Sarbanes. (2010b). Sarbanes-Oxley Act (SOx) Bagian 404. 


\section{BAB 4}

\section{PRINSIP PENGENDALIAN INTERNAL COSO}

\section{Capaian Pembelajaran}

1. Mahasiswa mampu memahami prinsip pengendalian internal coso.

2. Mahasiswa mampu memahami prinsip lingkungan pengendalian.

3. Mahasiswa mampu memahami prinsip penilaian risiko

4. Mahasiswa mampu memahami prinsip aktivitas pengendalian.

5. Mahasiswa mampu memahami prinsip informasi dan komunikasi.

6. Mahasiswa mampu memahami prinsip monitoring pengendalian.

\section{A. Pendahuluan}

Kultur haruslah dipantau dalam setiap proses aktivitas dan harus sesuai nilai-nilainya. Artinya, nilai-nilai itu mungkin akan susah melihatnya tapi harus dipastikan melalui bukti-bukti atau indikator nyata yang tercermin dari behaviour dan hasil nyata. Ini sangat penting, karena ada juga orang terlihat baik dan koperatif tapi tidak sesuai nilai-nilai aturan. Bahkan seorang pemimpin saja pun bisa melakukan hal-hal buruk karena faktorfaktor tertentu. Disinilah fungsi dari pengendalian lingkungan harus ditegakkan.

Risk Culture itu mengutamakan nilai, dan persepsi serta pemahaman mengenai nilai-nilai sangat menentukan bagaimana merespon sebuah risiko melalui sebuah pengendalian. Sekarang ini risiko ada dimana-mana dan oleh karena itu, pemahaman 
yang baik mampu memposisikan perusahaan sehingga mampu bersikap serta memitigasi risiko dengan baik.

Berbisnis yang baik dengan menggunakan konsep disertai risk management, control dan governance yang baik juga harus dipahami. Sehingga, auditor bisa memastikan bahwa risk appetite yang ditetapkan sudah sesuai dan mendukung pencapaian tujuan perusahaan. Jika SOP tak cukup maka Auditor Internal harus cukup.

Industry 4.0 sudah siap memaksa. Siapa cepat maka dialah yang perkasa. Siapa malas berpikir maka lebih baik tidur saja. Jangan pernah menghayal memenangkan Industry 4.0 jika saat manual dan otomatisasi masih tergopoh-gopoh berpikir. Dan jangan juga berharap langkah akan cepat pada Industry 4.0 jika saat industri sebelumnya hanya menghayal tanpa mempersiapkan ketangguhan berpikir dalam bertindak. Sebuah perusahaan yang tangguh biasanya akan senantiasa siap dengan segala sesuatu karena pikirannya tangguh. Perusahaan tangguh telah mempersiapkan dan bahkan mengucurkan modal atau investasi yang besar, karena Industry 4.0 adalah perang total dan pertunjukan aktualisasi, investasi strategis dan juga human capital yang adaptif dengan kecepatan. Jika kecepatan sangat erat kaitannya dengan waktu, maka Industry 4.0 membutuhkan human capital yang bisa mengimbangi serta memahami bahwa kecepatan otaklah yang bisa menggapai waktu. Transaksi otomasi dengan robot atau aplikasi tentu akan semakin intensif. Manusia digantikan mesin dan pelanggan berhadapan dengan mesin atau gadget melalui aplikasi dan aplikasi menggerakkan mesin untuk melayani pelanggan. Akhirnya, manusia hanya berjaga memantau apakah kebutuhan pelanggan sudah terpenuhi. 


\section{B. Prinsip Pengendalian Internal coso}

Kerangka kerja pengendalian internal COSO, didukung oleh 17 prinsip. Prinsip-prinsip ini memberikan lebih banyak panduan dan pemahaman tentang konsep-konsep pengendalian internal, meskipun tidak secara tepat melacak elemen-elemen kerangka kerja tersebut.

\begin{tabular}{|l|l|}
\hline \multicolumn{1}{|c|}{ Elemen } & \multicolumn{1}{|c|}{ Prinsip } \\
\hline Lingkungan & $\begin{array}{l}\text { 1. Organisasi menunjukkan komitmen terhadap } \\
\text { nilai-nilai integritas dan etika. } \\
\text { 2. Dewan menunjukkan kemandirian } \\
\text { manajemen dan menjalankan pengawasan } \\
\text { terhadap pengembangan dan bekerjanya } \\
\text { pengendalian internal. } \\
\text { 3. Dengan pengawasan Dewan, manajemen } \\
\text { menetapkan struktur, garis pelaporan, serta } \\
\text { wewenang dan tanggung jawab yang sesuai } \\
\text { dalam pencapaian tujuan. } \\
\text { 4. Organisasi menunjukkan komitmen untuk } \\
\text { menarik, dan } \\
\text { mempertahankan individu yang kompeten } \\
\text { dalam keselarasan dengan tujuan. }\end{array}$ \\
5. Organisasi mempertahankan individu dalam \\
tanggung jawab pengendalian internal mereka \\
dalam mengejar tujuan.
\end{tabular}




\begin{tabular}{|c|c|}
\hline & $\begin{array}{l}\text { 9. Organisasi mengidentifikasi dan menilai } \\
\text { perubahan-perubahan yang secara signifikan } \\
\text { dapat mempengaruhi sistem pengendalian } \\
\text { internal. }\end{array}$ \\
\hline $\begin{array}{l}\text { Aktivitas } \\
\text { Pengendalian }\end{array}$ & $\begin{array}{l}\text { 10. Organisasi memilih dan mengembangkan } \\
\text { aktivitas pengendalian yang turut memitigasi } \\
\text { risiko pencapaian tujuan pada tingkat yang } \\
\text { dapat diterima. } \\
\text { 11. Organisasi memilih dan mengembangkan } \\
\text { aktivitas pengendalian umum atas teknologi } \\
\text { untuk mendukung pencapaian tujuan. } \\
\text { 12. Organisasi menerapkan aktivitas } \\
\text { pengendalian sebagaimana dimanifestasikan } \\
\text { dalam kebijakan untuk menetapkan apayang } \\
\text { diharapkan, dan prosedur yang relevan } \\
\text { untuk menjalankan kebijakan. }\end{array}$ \\
\hline $\begin{array}{l}\text { Informasi } \\
\text { dan } \\
\text { Kommunikasi }\end{array}$ & $\begin{array}{l}\text { 13. Organisasi memperoleh atau menghasilkan } \\
\text { serta menggunakan informasi yang relevan } \\
\text { dan berkualitas untuk mendukung } \\
\text { berfungsinya komponen lain dari } \\
\text { pengendalian internal. } \\
\text { 14. Organisasi mengomunikasikan informasi } \\
\text { secara internal, termasuk komunikasi atas } \\
\text { tujuan dan tanggung jawab internal kontrol } \\
\text { internal, yang diperlukan untuk mensuport } \\
\text { berfungsinya komponen lain dari internal } \\
\text { kontrol. } \\
\text { 15. Organisasi berkomunikasi dengan pihak } \\
\text { eksternal tentang hal-hal yang } \\
\text { mempengaruhi berfungsinya komponen lain } \\
\text { dari pengendalian internal }\end{array}$ \\
\hline Monitoring & $\begin{array}{l}\text { 16. Organisasi memilih, mengembangkan, dan } \\
\text { melakukan evaluasi yang terus-menerus } \\
\text { (ongoing) dan/atau terpisah untuk }\end{array}$ \\
\hline
\end{tabular}




\begin{tabular}{|l|l|}
\hline & $\begin{array}{l}\text { memastikan apakah komponen-komponen } \\
\text { pengendalian internal ada dan berfungsi. } \\
\text { 17. Organisasi mengevaluasi dan } \\
\text { mengomunikasikan }\end{array}$ \\
pengendalian internal secara tepat waktu \\
kepada pihak-pihak yang sesuai dan \\
bertanggung jawab untuk mengambil \\
tindakan korektif, termasuk manajemen \\
senior dan Dewan
\end{tabular}

Gambar 4.1 Prinsip Pengendalian Internal COSO

Sumber : (Moeller, R.R.2016)

C. Prinsip Lingkungan Pengendalian 1: Integritas dan NilaiNilai Etis

Konsep ini membantu auditor internal untuk lebih mengembangkan dan melakukan tinjauan pengendalian internal. Banyak orang menyangka bahwa kultur yang baik akan terbentuk otomatis jika perusahaan sudah lama dan sudah banyak aturan yang dibuat. Ternyata, tidak semudah itu. Karena banyak juga perusahaan besar yang bobol di sana sini. Prinsipnya, manusia itu baik namun seberapa penting kebaikan dan apa nilai kebaikan dari attitude dan behaviour juga perlu disadari dan menjadi komitmen.

Prinsip pertama dari lingkungan pengendalian COSO menuntut perusahaan untuk menunjukkan komitmen terhadap integritas dan nilai-nilai etika (COSO Internal Control, 2013). Sejarah dan budaya perusahaan sering memainkan peran utama dalam membentuk lingkungan internal kontrol ini. Ketika perusahaan secara historis memiliki penekanan yang kuat pada proses produksi yang bebas kesalahan (zero defect), ketika manajemen senior terus menekankan pentingnya produk berkualitas tinggi, dan ketika pesan ini disampaikan ke semua 
tingkatan, ini menjadi faktor lingkungan pengendalian perusahaan yang utama.

Pesan dari CEO harus menekankan bahwa suatu perusahaan berkomitmen terhadap standar etika tertinggi dalam setiap aspek bisnisnya, seperti; kepatuhan dalam bisnisnya, penjualan, konseling hukum, dan praktik sumber daya manusia serta perlakuannya terhadap karyawan dan pelanggan.

CEO memimpin dengan memberikan contoh perilaku pada masalah integritas dan etika; tindakan positif ini merupakan batu fondasi membangun lingkungan pengendalian yang kuat untuk perusahaan. Walaupun pesan CEO sangat penting, kode etik perusahaan yang efektif lebih penting dalam membangun lingkungan pengendalian intern yang efektif. Kode etik telah ada di organisasi bisnis selama bertahun-tahun, tetapi secara tradisional lebih terfokus pada anggota staf tingkat bawah daripada pada manajemen senior. Saat ini kode etika sudah menjadi komponen penting dari sistem pengendalian intern yang efektif untuk semua anggota perusahaan, dari manajemen senior hingga staf operasi dan pemangku kepentingan lainnya.

\section{Menegaskan Kepatuhan pada Kode Etik}

Kode etik perusahaan harus merupakan dokumen hidup. Manajemen senior perusahaan diwajibkan untuk secara resmi mengakui bahwa mereka telah membaca, memahami, dan akan mematuhi kode etik perusahaan. Sosialisasi kode etik dapat dilakukan dalam beberapa fase, dengan pengiriman ke pusat perusahaan, diikuti oleh unit yang lebih kecil, lokasi asing, dan pemangku kepentingan lainnya. Perubahan kode etik dapat dikomunikasikan melalui video oleh CEO, melalui siaran web, sesi pelatihan, atau cara lain untuk menekankan pentingnya kode etik untuk pencapaian tujuan perusahaan. 
Metode komunikasi khusus dapat digunakan untuk kelompok lain seperti vendor atau kontraktor, tetapi tujuan perusahaan haruslah untuk membuat semua pemangku kepentingan secara resmi mengakui bahwa mereka mematuhi kode etik perusahaan, di mana setiap pemangku kepentingan perusahaan diminta untuk menjawab tiga pertanyaan berikut:

a. Sudahkah Anda menerima dan membaca salinan kode etik? Jawab "ya" atau "tidak".

b. Apakah Anda memahami isi kode etik ini? Jawab "ya" jika Anda memahami kode etik ini atau tidak jika Anda memiliki pertanyaan.

c. Apakah Anda setuju untuk mematuhi kebijakan dan pedoman dalam kode etik ini? Jawab " $y a$ " jika Anda setuju untuk mematuhi kode dan jawab "tidak" jika Anda tidak setuju mematuhi kode etik.

Tanggapan dari pertanyaan diatas dicatat pada database yang mencantumkan nama karyawan dan tanggal peninjauan dan penerimaan. Hal ini dilakukan untuk membuat semua pemangku kepentingan menerima dan menyetujui ketentuan kode etik. Jika seseorang menolak untuk menerima kode, maka harus dilakukan mendiskusikan dengan orang tersebut untuk mendapatkan penyelesaian akhirnya. Masalah terakhir di sini adalah bahwa perusahaan harus mewajibkan semua karyawan setuju untuk menerima dan mematuhi kode etik perusahaan. Mengikuti kode itu harus menjadi aturan kerja perusahaan, dan kegagalan mematuhi kode etik secara konstan harus menjadi dasar untuk penghentian karyawan.

\section{Pelanggaran Kode dan Tindakan Korektif}

Kode etik di seluruh perusahaan menjabarkan serangkaian perilaku yang diharapkan. Selain menerbitkan kode etik dan 
mendapatkan penerimaan pemangku kepentingan, perlu juga ada mekanisme untuk melaporkan pelanggaran kode dan untuk menyelidiki dan menangani pelanggaran tersebut. Tujuannya di sini adalah bahwa jika perusahaan mengeluarkan kode yang kuat tentang pentingnya praktik etika yang baik, semua pemangku kepentingan diharapkan untuk mengikuti aturan itu.

Namun, kita semua tahu bahwa manusia adalah manusia dan akan selalu ada beberapa yang melanggar aturan atau berjalan di ujung tanduk. Perusahaan perlu membuat mekanisme untuk memungkinkan karyawan atau bahkan orang luar melaporkan potensi pelanggaran kode etik dengan cara yang aman dan rahasia. Sebagian besar mekanisme pelaporan itu dapat ditangani melalui fasilitas whistleblower.

Ketika pelanggaran ditemukan, masalah tersebut harus diselidiki dan diambil tindakan secara konsisten, tidak peduli peringkat para pemangku kepentingan, hukuman untuk pelanggaran harus konsisten. Kalau tidak, mungkin ada suasana di mana aturan itu hanya berlaku untuk beberapa orang saja.

\section{Prinsip Lingkungan Pengendalian 2: Peran Direksi}

Lingkungan pengendalian sangat dipengaruhi oleh tindakan dewan direksi dan komite auditnya, dengan prinsip "Pastikan bahwa dewan menjalankan tanggung jawab pengawasan." Pada tahun-tahun sebelum Sarbanes-Oxley Act (SOx), dewan dan komite audit sering didominasi oleh manajemen senior di dalam direksi, dengan perwakilan terbatas dewan dan komite audit dari independen. Ini menciptakan situasi di mana dewan tidak sepenuhnya independen dari manajemen. Sarbanes-Oxley Act 
(SOx) mengubah ini dan mengharuskan komite audit benar-benar independent (Sarbanes, 2010a).

Dewan independen harus memiliki hubungan yang erat dengan manajemen senior untuk memastikan operasi perusahaan yang efektif dan lingkungan pengendalian internal yang kuat. Dewan direksi dan komite audit harus mengidentifikasi dan memahami harapan para pemangku kepentingan, pelanggan, karyawan, investor, dan masyarakat umum, serta persyaratan hukum dan peraturan perusahaan. Kegiatan dewan direksi harus dapat membantu manajemen dalam menentukan apakah prinsip lingkungan pengendalian COSO ini ada dan berfungsi (COSO Internal Control, 2013).

a. Tetapkan tanggung jawab pengawasan. Dewan direksi harus mengidentifikasi dan menerima tanggung jawab pengawasannya sehubungan dengan persyaratan hukum yang ditetapkan dan pemangku kepentingan, investor, dan harapan publik.

b. Terapkan keahlian yang relevan. Dewan direksi harus mendefinisikan, memelihara, dan secara berkala mengevaluasi keterampilan dan keahlian yang diperlukan di antara para anggotanya untuk memungkinkan mereka mengajukan pertanyaan menyelidik tentang manajemen senior dan mengambil tindakan yang sepadan.

c. Beroperasi secara independen. Dewan direksi harus memiliki anggota yang cukup dari pihak independen dan objektif dalam evaluasi dan pengambilan keputusan mereka.

d. Berikan pengawasan untuk sistem pengendalian intern. Dewan direksi harus memiliki tanggung jawab pengawasan untuk pengembangan manajemen dan kinerja pengendalian intern. 
Dewan dan komite audit memberikan pengawasan terhadap sistem pengendalian internal, untuk memastikan bahwa prinsip lingkungan pengendalian internal ini ada dan berfungsi.

\section{E. Prinsip Lingkungan Pengendalian 3: Kebutuhan Otoritas dan}

\section{Tanggungjawab}

Manajemen harus menetapkan, dengan pengawasan dewan tentang;
a. struktur,
b. jalur pelaporan,
c. otoritas dan
d. tanggung jawab

Harus ada struktur organisasi untuk merencanakan, melaksanakan, mengendalikan, dan secara berkala menilai kegiatan perusahaan secara keseluruhan. Tujuan lingkungan pengendalian ini adalah untuk memberikan pertanggung jawaban dan arus informasi yang jelas di seluruh perusahaan secara keseluruhan dan semua sub-unitnya.

Banyak perusahaan dari semua jenis dan ukuran saat ini telah merampingkan operasi serta memacu otoritas pengambilan keputusan ke bawah. Lingkungan pengendalian yang kuat mengatakan bahwa karyawan garis depan harus memiliki pengetahuan dan kekuatan untuk membuat keputusan yang tepat di wilayah operasi mereka sendiri daripada pengambilan keputusan melalui saluran perusahaan yang lebih senior. Tantangan kritis yang terjadi pada delegasi adalah perusahaan dapat menempatkan dirinya dalam risiko jika terlalu banyak keputusan tingkat atas ditetapkan pada tingkat yang lebih rendah secara tidak tepat tanpa tinjauan manajemen yang memadai.

Setiap orang di perusahaan harus memiliki pemahaman yang baik tentang tujuan perusahaan serta bagaimana tindakan individu 
saling terkait untuk mencapai tujuan tersebut. Manajemen perusahaan harus menyadari bahwa komponen lingkungan sangat dipengaruhi oleh sejauh mana individu mengakui bahwa mereka akan bertanggung jawab atas keputusan yang diambil. Hal ini berlaku untuk semua anggota perusahaan, mulai dari anggota staf hingga CEO, yang memiliki tanggung jawab utama untuk semua kegiatan dalam suatu entitas, termasuk sistem pengendalian intern.

\section{F. Prinsip Lingkungan Pengendalian 4: Komitmen Kepada Pekerja yang Kompeten}

Perusahaan harus menunjukkan komitmen untuk menarik, mengembangkan, dan mempertahankan pekerja yang kompeten sesuai dengan tujuannya. Perusahaan membutuhkan keterampilan dan keahlian yang relevan, yang sebagian besar diperoleh dari pengalaman profesional, pelatihan, dan sertifikasi. Komitmen terhadap kompetensi dinyatakan dalam sikap dan perilaku individu dalam melaksanakan tanggung jawab. Prinsip lingkungan pengendalian meminta perusahaan untuk mendefinisikan persyaratan kompetensi karyawan sebagaimana diperlukan untuk mendukung pencapaian tujuan pengendalian internal, dengan pertimbangan diberikan kepada:

a. Pengetahuan, keterampilan, dan kebutuhan pengalaman

b. Sifat dan tingkat penilaian dan keterbatasan wewenang untuk diterapkan pada posisi tertentu

c. Analisis biaya-manfaat dari berbagai tingkat keterampilan dan pengalaman

d. Pertukaran antara tingkat pengawasan dan tingkat kompetensi yang dipersyaratkan dari masing-masing karyawan

Prinsip ini mengatakan bahwa dewan direksi harus mengevaluasi kompetensi CEO, dan pada gilirannya, manajemen 
harus mengevaluasi kompetensi di seluruh perusahaan dalam kaitannya dengan kebijakan dan prosedur yang ditetapkan serta bertindak seperlunya untuk mengatasi setiap kekurangan atau kelebihan. Kekurangan mungkin timbul terkait dengan tingkat kepegawaian, keterampilan, keahlian, atau kombinasi dari faktorfaktor tersebut. Manajemen bertanggung jawab untuk bertindak atas kekurangan tersebut tepat waktu.

\section{G. Prinsip Pengendalian Lingkungan 5: Memegang Orang-orang Accountable}

Manajemen dan dewan direksi harus menetapkan mekanisme untuk berkomunikasi dan meminta pertanggungjawaban individu atas kinerja pengendalian internal di seluruh organisasi dan menerapkan tindakan korektif seperlunya. Manajemen dan dewan direksi harus menetapkan ukuran kinerja, insentif, dan imbalan lain yang sesuai untuk tanggung jawab di semua tingkatan entitas, mencerminkan dimensi kinerja yang sesuai dan standar perilaku serta kinerja yang diharapkan.

Secara khusus, dewan direksi pada akhirnya meminta pertanggungjawaban CEO atas pengendalian internal dalam pencapaian tujuan perusahaan, CEO dan manajemen senior bertanggung jawab untuk merancang, melaksanakan, dan secara berkala mengevaluasi apakah struktur, otoritas, dan tanggungjawab dapat membangun akuntabilitas untuk pengendalian internal di semua tingkatan perusahaan. Akuntabilitas di sini mengacu pada tingkat kepemilikan dan komitmen terhadap kinerja pengendalian internal dalam mengejar tujuan. Manajemen dan dewan harus menetapkan mekanisme untuk berkomunikasi dan meminta pertanggungjawaban personil atas kinerja pengendalian internal di seluruh perusahaan dan harus mengambil tindakan yang sesuai. 
Prinsip pengendalian internal coso menekankan bahwa manajemen dan karyawan pada semua tingkatan harus bertanggungjawab atas pengelolaan pengendalian internal yang terkait kekuatan dan kelemahan.

\section{H. Prinsip Penilaian Risiko 6: Menentukan Tujuan Penilaian Risiko Yang Tepat}

Risiko adalah suatu situasi atau kondisi ketidakpastian yang dianggap dapat mengganggu rencana pencapaian tujuan. Oleh karena itu sering juga disebut sebagai probabilitas terjadinya events yang dapat mengganggu dan menggagalkan pencapaian tujuan. Oleh karena risiko itu adalah masalah prediksi ke waktu yang akan datang, maka perlu aspek logis dalam memberikan ukuran terjadinya suatu risk event. Persepsi risiko ini sangat penting, sehingga seorang auditor internal bisa berfikir logis dan rasionil dalam menafsirkan risiko yang terekspos pada seluruh produk atau proses bisnis yang mugkin akan menjadi objek pemeriksaannya (Gultom, 2018).

Kemampuan untuk mempersepsikan risiko secara logis, membuat auditor internal membangun komunikasi yang baik dengan audite dan akan tercipta pertukaran ide untuk membuat proses manajen risiko, pengendalian dan tata kelola semakin baik. Ketika auditee sedikit menyimpang dari kebijakan perusahaan, maka auditor internal harus mengidentifikasi tambahan risiko dan mengukur potensi dampaknya agar dapat mengkomunikasikannya dengan baik, atau memberikan rekomendasi perbaikan kebijakan tersebut. Pengelolaan risiko pengendalian internal mempengaruhi;

a. Kemampuan perusahaan untuk berhasil bersaing secara efektif dalam industrinya,

b. Mempertahankan kekuatan keuangan dan reputasi positifnya, dan 
c. Mempertahankan kualitas produk, layanan, dan orangorangnya secara keseluruhan.

Selalu ada beberapa risiko dalam aktivitas bisnis apa pun dan tidak ada cara praktis untuk mengurangi semuanya. Manajemen, bagaimanapun, harus menentukan secara hati-hati berapa banyak risiko yang harus diterima dan berusaha untuk mempertahankan risiko dalam batas-batas ini.

\section{Prinsip Penilaian Risiko 7: Mengidentifikasi dan Menganalisis Risiko}

\section{Mengidentifikasi Risiko}

Pada dasarnya risiko tidak bisa dihilangkan, tapi bisa dikelola untuk meminimalkan potensi kerugian. Untuk mengelola risiko bisnis secara tepat, perusahaan perlu mengidentifikasikan risiko strategis, risiko operasional dan risiko keuangan. Risiko bisa disebab faktor internal atau eksternal, mungkin terjadinya melibatkan internal dan eksternal bergabung dan berinteraksi pada waktu yang sama.

Manajemen perusahaan, auditor internal dan manajer subunit harus mengidentifikasi semua kemungkinan risiko pengendalian internal yang dapat mempengaruhi perusahaan, mulai dari risiko rendah hingga risiko yang lebih besar atau lebih signifikan. Karena risiko terjadinya dimasa depan, maka proses identifikasi risiko memerlukan pendekatan yang sesuai untuk melihat potensi risiko di setiap area dan kemudian mengidentifikasi area risiko dengan kreteria, rendah, sedang, tinggi. Agar efektif, proses identifikasi risiko perusahaan harus didukung oleh berbagai kegiatan, teknik, dan mekanisme, yang relevan dengan penilaian risiko secara keseluruhan. Manajemen harus mempertimbangkan risiko di semua tingkatan dan mengambil langkah-langkah yang diperlukan untuk mengelolanya. 


\section{Menganalisis Risiko}

Ketika melakukan assurance dan consulting auditor internal harus memanfaatkan waktu dan pengetahuan serta keterampilan sosial yang dimiliki agar hasil identifikasi risiko strategis, risiko operasional dan risiko keuangan memberikan nilai tambah pada perusahaan. Menganalisis risiko harus menjadi proses berulang yang berkelanjutan yang dilakukan untuk meningkatkan kemampuan perusahaan mencapai tujuannya. Penilaian risiko harus mempertimbangkan faktor-faktor yang mempengaruhi tingkat keparahan, kecepatan, dan ketahanan risiko, kemungkinan hilangnya aset, dan dampak terkaitnya pada operasi, pelaporan, dan kegiatan kepatuhan.

Prinsip identifikasi dan analisis risiko coso menyerukan pertimbangan semua risiko dalam suatu perusahaan, subunit dan fungsi operasionalnya, seperti keuangan, sumber daya manusia, pemasaran, produksi, pembelian, dan manajemen TI.

Dalam melakukan penilaian risiko manajemen harus mempertimbangkan laju perubahan dalam menentukan frekuensi proses penilaian risiko. Penilaian risiko adalah proses yang dinamis, perusahaan harus menggunakan kombinasi penilaian risiko yang sedang berlangsung dan periodik. Auditor internal dapat memainkan peran penting di sini, baik dalam perencanaan audit internal berbasis risiko dan identifikasi "boot on the ground" dari area risiko potensial sebagai bagian dari audit internal di lokasi lapangan.

\section{J. Prinsip Penilaian Risiko 8: Penilaian Risiko Kecurangan}

Normalnya, perusahaan yang sudah mapan dan menggunakan pengalamannya akan semakin baik mengelola operasional dan bisnisnya. Proses manajemen risiko akan semakin mature dan seluruh risiko utama yang bisa mengganggu penjualan produk akan 
diidentifikasi dengan baik, termasuk fraud risk (https://na.theiia.org, 2018).

Bahwa dalam tata kelola sistem risiko dikenal adanya terminologi first, second and third line of defense. Jika tata kelola terlaksana dengan baik, dan terjadi mekanisme strategic process melalui peran masing-masing personal dalam perusahaan, maka kemungkinan risiko yang melebihi appetite akan jarang terjadi. Auditor internal sebagai third line of defense, sesuai dengan standard IPPF sangat diharapkan memahami perannya sehingga bisa memberikan kontribusi bagi kemajuan perusahaan dan terhindar dari kerugian-kerugian yang seharusnya bisa dihindari.

Semakin kompleks aktivitas perusahaan, maka akan semakin banyak pula kemungkinan proses yang berisiko dan mengharuskan auditor internal memiliki ilmu dan keahlian untuk menerapkan teknik-teknik audit serta mampu mengenali indikator-indikator kecurangan dalam setiap aktivitas bisnis perusahaan.

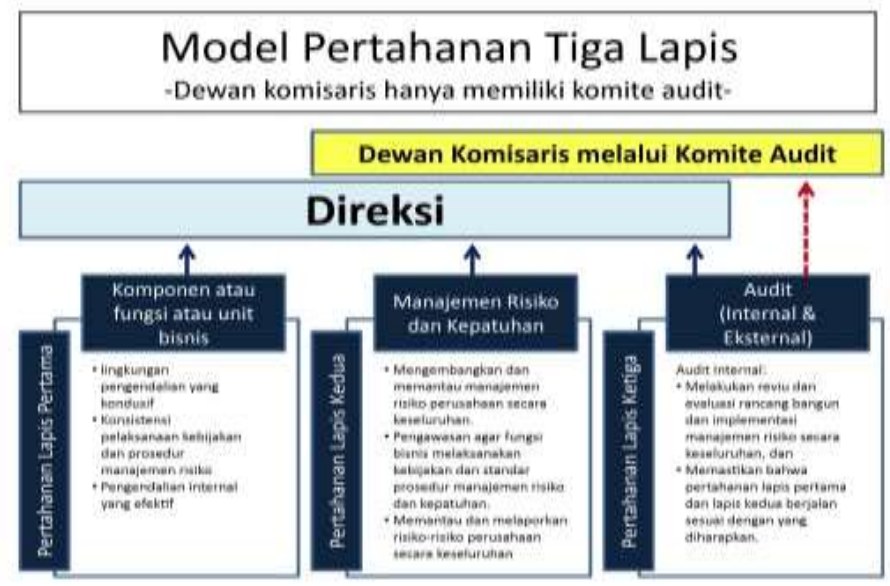

Gambar 4.2 Model Pertahanan Tiga Lapis

Sumber : (Gultom, 2019b) 
Selain itu, auditor internal juga harus mampu mengevaluasi pengendalian yang ada, apakah sudah cukup untuk memitigasi kemungkinan adanya kecurangan baik kecurangan external maupun kecurangan internal. Auditor internal sering berada dalam posisi yang sangat baik untuk mengevaluasi risiko kecurangan karena kegiatan peninjauan yang berkelanjutan di seluruh perusahaan.

Mengevaluasi risiko berdasarkan kemungkinan dan signifikansi keiadian

Identifikasi unit bisnis, lokasi, atau proses untuk menilai

Pantau dan kategorikan risiko dan kejadian kecurangan dan pelanggaran

Remediasi risiko melalui optimalisasi pengendalian

Gambar 4.3 Penilaian Risiko Fraud

Sumber : (Sarbanes, 2010a)

Penilaian risiko kecurangan adalah proses yang harus digunakan perusahaan untuk menentukan paparannya terhadap kecurangan internal dan eksternal. Penilaian harus meninjau operasi dan pengendalian, termasuk kebijakan dan prosedur, untuk menentukan di mana ada celah yang memungkinkan seseorang atau sekelompok orang untuk melakukan kecurangan. Penilaian risiko kecurangan kemudian harus memotret bidang-bidang utama di perusahaan untuk menentukan apakah telah diambil tindakan secara efektif untuk mencegah kecurangan. Setiap perusahaan 
memiliki tingkat risiko dan teknik mitigasi yang berbeda tergantung pada industrinya. Perusahaan manufaktur dengan persediaan bernilai tinggi per unit memiliki risiko yang berbeda dari perusahaan teknologi perangkat lunak dengan kekayaan intelektual yang berharga. Setiap penilaian risiko perlu disesuaikan dengan organisasi dan risiko spesifik yang dihadapinya.

Standar IIA menekankan bahwa audit internal memiliki peran untuk dimainkan terkait deteksi dan pencegahan kecurangan, tetapi tanggung jawab utama berada pada manajemen.

\section{K. Prinsip Penilaian Risiko 9: Mengidentifikasi Perubahan yang} Mempengaruhi Pengendalian Intern

Perubahan kondisi dapat mempengaruhi pengendalian intern tingkat entitas, seperti perubahan kepemimpinan, perubahan proses bisnis yang strategis, perubahan struktur organisasi (Gultom, 2019a). Dalam dunia bisnis salah satu perubahan yang berpengaruh terhadap pengendalian intern adalah "revolusi industri" dan saat ini perusahaan sedang berada pada revolusi industri 4.0. Perkembangan teknologi informasi mengubah bisnis dan pengendalian internal.

Dengan demikian diperusahaan tentu banyak aset yang berupa teknologi dan tidak banyak sumberdaya manusia. Pembuatan dan pengembangan bisnis berbasis virtual office. Cara menjual produk atau jasa melalui online marketpalce. Perkembangan teknologi baru akan menciptakan standar baru, pengendalian internal baru dan keseimbangan baru.

Oleh sebab itu perusahaan harus mengembangkan strategi manajemen risiko menyelaraskan dengan perubahan yang terjadi. Keterlambatan merespon perubahan apapun, berarti terlambat juga mengidentifikasi risiko, gagal juga menyusun perangkat untuk mengevaluasi risiko yang dinamakan pengendalian internal, 
kegagalan merespon dapat menyebabkan penyakit komplikasi dan membangkrutkan bisnis. Karena strategi respons risiko adalah komponen kunci dari pengendalian internal coSO.

Proses strategi respon risiko adalah setelah potensi risiko signifikansi diidentifikasi, manajemen harus mempertimbangkan bagaimana risiko tersebut harus dikelola. Pengelolaan risiko tentu tergantung dari selera risiko yang siap ditanggung perusahaan, oleh sebab itu pengelolaan risiko sering melibatkan penilaian berdasarkan asumsi biaya dan manfaat yang terkait dengan pengurangan tingkat risiko. Manajemen harus mempertimbangkan tindakan pada masing-masing dari empat strategi respons risiko dasar yaitu penghindaran, pengurangan, pembagian, dan penerimaan risiko.

L. Prinsip Aktivitas Pengendalian 10: Memilih Aktivitas Pengendalian yang Mengatasi Risiko

Prinsip kegiatan pengendalian coso menyatakan bahwa, sebagai bagian dari keseluruhan lingkungan pengendalian internal, perusahaan harus memilih dan mengembangkan aktivitas pengendalian yang berkontribusi pada mitigasi risiko pengendalian internal untuk pencapaian sasaran ke tingkat yang dapat diterima. Aktivitas pengendalian mencakup tindakan yang memastikan bahwa respons terhadap risiko yang dinilai, serta arahan manajemen lainnya seperti menetapkan kode etik perusahaan dilakukan dengan benar dan tepat waktu.

Karena setiap perusahaan memiliki serangkaian tujuan dan pendekatan penerapannya sendiri, akan selalu ada perbedaan dalam tujuan, risiko, respons, dan aktivitas pengendalian terkait. Setiap perusahaan dikelola oleh orang yang berbeda dengan keterampilan berbeda yang menggunakan teknik masing-masing dalam melakukan pengendalian internal. Selain itu, pengendalian 
mencerminkan lingkungan dan industri tempat perusahaan beroperasi serta kompleksitas organisasinya, sejarah, budaya, dan ruang lingkup operasinya.

Faktor spesifik perusahaan dapat mempengaruhi aktivitas pengendalian yang diperlukan untuk mendukung sistem pengendalian internal mereka:

a. Lingkungan dan kompleksitas perusahaan serta sifat dan ruang lingkup operasinya, baik secara fisik maupun logis, semuanya dapat mempengaruhi aktivitas pengendalian perusahaan.

b. Perusahaan yang sangat teregulasi umumnya memiliki respons risiko dan aktivitas pengendalian yang lebih kompleks daripada entitas yang tidak terlalu teregulasi.

c. Cakupan dan sifat respons risiko dan aktivitas pengendalian untuk perusahaan multinasional dengan beragam operasi pada umumnya struktur pengendalian internal yang lebih kompleks daripada struktur perusahaan domestik dengan aktivitas yang kurang beragam.

d. Perusahaan dengan sistem perencanaan sumber daya perusahaan yang cukup canggih, akan memiliki kegiatan pengendalian yang berbeda dari yang menggunakan sistem IT yang kurang canggih.

e. Perusahaan dengan operasi terdesentralisasi dan penekanan pada otonomi dan inovasi lokal menghadirkan lingkungan pengendalian yang berbeda dari yang lain yang operasinya konstan dan sangat tersentralisasi.

Ketika membangun proses pengendalian internal, suatu perusahaan perlu memikirkan ukuran relatif dan kompleksitas perusahaan. Satu ukuran tidak cocok untuk semua, dan manajemen harus mempertimbangkan ukuran relatif perusahaan dan harus membuat akomodasi pengendalian internal berdasarkan ukuran 
relatif dan pertimbangan lingkungan operasi lainnya. Pemilihan dan pengembangan aktivitas pengendalian perusahaan yang kuat dapat memitigasi risiko keseluruhan.

\section{Prinsip Aktivitas Pengendalian 11: Memilih dan Mengembangkan Pengendalian Teknologi}

coso menggunakan istilah teknologi dalam prinsip ini, dan dapat mencakup bidang-bidang seperti pembuatan robotika, instrumen pengujian farmasi, dan pengembangan produk video elektronik yang berorientasi konsumen. Semua produk teknologi ini banyak masalah pengendalian intern benar-benar di luar jangkauan banyak auditor internal.

Ada banyak jenis pengendalian TI yang terkait dengan teknis, manajemen, dan tata kelola yang mencakup segala sesuatu mulai dari kebijakan TI manajemen tingkat tinggi hingga pengendalian proses untuk aplikasi tertentu dan bahkan berjalan pada perangkat genggam.

N. Prinsip Aktivitas Pengendalian 12: Kebijakan dan Prosedur

Prinsip kegiatan pengendalian coso menyerukan perusahaan untuk menyebarkan kegiatan pengendaliannya melalui kebijakan dan prosedur. Pengendalian kebijakan adalah kegiatan menentukan dan menetapkan apa yang diharapkan, dan prosedur menerapkan kebijakan tersebut. Perusahaan biasanya memiliki banyak kebijakan dan prosedur untuk mencapai tujuannya, aktivitas pengendalian harus dibuat secara spesifik berkaitan dengan kebijakan dan prosedur tersebut dan berkontribusi pada mitigasi risiko untuk pencapaian tujuan.

Perusahaan harus mensosialisasikannya beberapa kebijakan dan prosedur. Kebijakan yang diterbitkan perusahaan harus memiliki elemen berikut: 
a. Tujuan kebijakan. Harus ada pernyataan tingkat tinggi yang menguraikan maksud atau tujuan tingkat tinggi dari kebijakan tersebut.

b. Lokasi dan penerapan. Harus ada definisi apakah kebijakan tersebut hanya berlaku untuk beberapa unit atau bersifat global.

c. Peran dan tanggung jawab. Deskripsi harus mencakup semua orang yang terlibat dalam kebijakan.

Kebijakan harus menetapkan tanggung jawab dan akuntabilitas individu yang jelas dan dilaksanakan secara konsisten oleh personel yang kompeten. Prinsip kegiatan pengendalian ini menyerukan langkah-langkah tindakan berikut:

a. Tetapkan kebijakan dan prosedur untuk mendukung penyebaran arahan manajemen.

b. Tetapkan tanggung jawab dan pertanggung jawaban untuk melaksanakan kebijakan dan prosedur.

c. Lakukan dengan menggunakan personel yang kompeten.

d. Ambil tindakan korektif bila perlu.

e. Menilai kembali kebijakan dan prosedur.

O. Prinsip Informasi dan Komunikasi 13: Menggunakan Informasi yang Relevan dan Berkualitas

Suatu perusahaan harus memperoleh dan menggunakan informasi yang relevan dan berkualitas untuk mendukung berfungsinya komponen-komponen pengendalian internal. Informasi diperlukan bagi perusahaan untuk melaksanakan tanggung jawab pengendalian internal dalam mendukung pencapaian tujuan. Informasi tentang "tujuan perusahaan" dirangkum sedemikian rupa oleh dewan direksi dan manajemen sehingga manajemen lini dan pihak lain dapat memahami tujuan ini dan mengetahui peran mereka dalam pencapaian tujuan 
perusahaan. Manajemen senior, spesialis $\mathrm{TI}$, auditor internal, dan lainnya, harus mensurvei sumber daya input dan output dari informasi manajemen dan keuangan masa lalu untuk mengidentifikasi dan mendefinisikan dengan lebih baik persyaratan informasi yang relevan.

Untuk mendapatkan informasi yang relevan mengharuskan manajemen untuk mengidentifikasi dan menetapkan persyaratan informasi pada tingkat detail. Mengidentifikasi persyaratan informasi adalah proses berulang dan berkelanjutan yang terjadi sepanjang kinerja sistem pengendalian internal yang efektif.

Jumlah informasi dan data dasar yang tersedia untuk manajemen sering kali lebih dari yang dibutuhkan karena meningkatnya sumber informasi dan kemajuan dalam pengumpulan, pemrosesan, dan penyimpanan data. Dalam kasus lain, data mungkin sulit diperoleh pada tingkat yang relevan. Oleh karena itu, pemahaman yang jelas tentang persyaratan informasi yang ditentukan COSO mengarahkan manajemen dan personel lain untuk mengidentifikasi sumber informasi yang relevan dan dapat diandalkan.

\section{Sumber Informasi yang Relevan}

Dengan meningkatnya penggunaan video, suara, komunikasi melalui internet dan sumber nirkabel, informasi internal dan eksternal juga diterima dari berbagai sumber dan dalam berbagai bentuk dan format. Dalam mengelola informasi dari sumber eksternal, manajemen harus mempertimbangkannya dalam ruang lingkup yang komprehensif tentang peristiwa, kegiatan, sumber data dan memilih yang paling relevan serta berguna untuk struktur organisasi, bisnis model, atau tujuan perusahaan. Ketika perubahan pada suatu perusahaan terjadi, persyaratan informasi juga harus berubah. 
Perusahaan yang beroperasi dalam lingkungan bisnis yang sangat dinamis dapat mengalami perubahan terus-menerus, sering kali disebabkan oleh aktivitas pesaing yang sangat inovatif dan bergerak cepat yang mengubah ekspektasi pelanggan. Selain itu, perusahaan menghadapi masalah regulasi yang terus berkembang, masalah globalisasi, dan tantangan dari inovasi teknologi. Dengan demikian manajemen harus secara teratur mengevaluasi kembali persyaratan informasinya dan menyesuaikan dengan sifat, luas, dan sumber informasi serta data yang mendasarinya untuk memenuhi kebutuhannya yang berkelanjutan.

\section{Memproses Data melalui Sistem Informasi}

COSO menggunakan frasa sistem informasi dalam arti yang agak luas, yang berarti sistem teknologi informasi (TI) dan keseluruhan proses terkait lainnya baik berbasis manual dan $\mathrm{TI}$ untuk menangkap, menganalisis, menyimpan, dan mendistribusikan semua jenis informasi bisnis. Perusahaan mengembangkan sistem informasi untuk menangkap, dan memproses data dalam volume besar dari sumber internal dan eksternal menjadi informasi yang bermakna dan dapat ditindaklanjuti untuk memenuhi persyaratan informasi yang ditetapkan. Sistem informasi mencakup kombinasi orang, proses, dan teknologi yang mendukung proses bisnis yang dikelola secara internal.

Informasi dapat diperoleh melalui berbagai bentuk, termasuk input atau kompilasi manual, atau melalui penggunaan proses $\mathrm{TI}$ seperti antarmuka pemrograman aplikasi tautan otomatis. Percakapan dengan pelanggan, pemasok, regulator, dan karyawan juga merupakan sumber data dan informasi penting yang diperlukan untuk mengidentifikasi dan menilai risiko dan 
peluang. Dalam beberapa kasus, informasi dan data dasar yang ditangkap memerlukan kekhususan. Dalam kasus lain, informasi dapat diperoleh langsung dari sumber internal atau eksternal.

Akses yang lebih besar ke informasi umumnya akan meningkatkan pengendalian internal. Akan tetapi, peningkatan volume informasi dan data yang mendasarinya dapat menciptakan risiko tambahan seperti risiko operasional yang disebabkan oleh ketidakefisienan karena kelebihan data, atau risiko kepatuhan yang terkait dengan undang-undang dan peraturan terkait perlindungan data, retensi, privasi, dan masalah keamanan yang timbul dari sifat data yang disimpan oleh atau atas nama perusahaan.

Sistem informasi yang dikembangkan dengan proses terintegrasi yang didukung teknologi memberikan peluang bagi perusahaan untuk meningkatkan efisiensi, kecepatan, dan aksesibilitas informasi kepada pengguna. Selain itu, sistem informasi tersebut dapat meningkatkan pengendalian internal atas risiko keamanan dan privasi yang terkait dengan informasi yang diperoleh dan dihasilkan oleh perusahaan. Sistem informasi harus dirancang dan diimplementasikan dengan membatasi akses ke informasi dengan "password" serta mengurangi jumlah titik akses guna meningkatkan efektivitas risiko migrasi terkait dengan keamanan dan privasi informasi.

Mencapai keseimbangan yang tepat antara manfaat dan biaya untuk mendapatkan dan mengelola informasi serta sistem pendukung adalah pertimbangan utama dalam membangun sistem informasi yang memenuhi kebutuhan perusahaan.

\section{P. Prinsip Informasi dan Komunikasi 14: Komunikasi Internal}

Perusahaan secara internal harus mengkomunikasikan informasi pengendalian internal, termasuk tujuan dan tanggung 
jawabnya, untuk mendukung berfungsinya komponen-komponen lain dari pengendalian internal. Komunikasi informasi ini harus disampaikan kepada semua elemen di seluruh perusahaan dan termasuk:

a. Pentingnya, relevansi, dan manfaat dari pengendalian internal yang efektif

b. Peran dan tanggung jawab manajemen dan personel lain dalam melakukan proses pengendalian internal tersebut

c. Harapan perusahaan untuk berkomunikasi segala hal penting yang berkaitan dengan pengendalian internal, termasuk contoh kelemahan, kemunduran, atau ketidakpatuhan

Perusahaan harus menetapkan dan menerapkan kebijakan dan prosedur yang memfasilitasi komunikasi internal yang efektif. Manajemen senior harus mengomunikasikan tujuan perusahaan dengan jelas sehingga manajemen dan personel lain, termasuk yang bukan karyawan seperti kontraktor, memahami peran individu mereka dalam organisasi.

\section{Komunikasi Pengendalian Internal}

Kepala eksekutif audit (CEA) mengkomunikasikan pengendalian internal dimulai dengan komunikasi tujuan perusahaan. Ketika CEA dan manajemen senior membuat komunikasi tujuan perusahaan agar individu;

a. memahami bagaimana peran dan tanggung jawab mereka berdampak pada pencapaian tujuan perusahaan pada tingkat tinggi.

b. memahami tanggung jawab pengendalian internal mereka ditanggapi dengan serius.

c. Melalui komunikasi tujuan dan sub-tujuan, individu harus memahami bagaimana peran, tanggung jawab, dan 
tindakan mereka berhubungan dengan pekerjaan orang lain dalam perusahaan

d. Memahami apa yang dianggap sebagai perilaku yang dapat diterima dan tidak dapat diterima.

e. Memahami penerapan pengendalian intern yang efektif.

f. Memahami dan mengenali masalah atau potensi masalah, menentukan penyebabnya, dan mengambil tindakan korektif.

Informasi yang berkaitan dengan pengendalian internal yang dikomunikasikan kepada dewan umumnya harus mencakup halhal signifikan tentang kepatuhan, perubahan, atau masalah yang timbul dari sistem pengendalian intern. Frekuensi dan tingkat perincian komunikasi kepada manajemen dan dewan direksi harus cukup yang memungkinkan anggota dewan memahami hasil penilaian terpisah dan berkelanjutan manajemen dan dampak dari hasil tersebut terhadap pencapaian tujuan. Selain itu, frekuensi dan tingkat perincian harus memadai untuk memungkinkan dewan direksi menanggapi indikasi pengendalian internal yang tidak efektif pada waktu yang tepat.

\section{Komunikasi Internal Melampaui Saluran Normal}

Agar informasi mengalir, naik, turun, dan lintas perusahaan, harus ada saluran komunikasi yang terbuka. Manajemen dan individu harus percaya bahwa penyelia mereka benar-benar ingin tahu tentang masalah terkait pengendalian internal tingkat sub-unit dan penyelia akan menanganinya seperlunya.

Dalam beberapa keadaan, jalur komunikasi yang terpisah diperlukan untuk membangun mekanisme rahasia ketika saluran normal tidak efektif. Banyak perusahaan telah membentuk fungsi etika dan beberapa jenis fungsi hotline di mana personel di semua tingkatan dapat menyampaikan kekhawatiran mereka 
setiap hari, melaporkannya, mengajukan pertanyaan, atau bahkan bertindak sebagai pelapor untuk melaporkan beberapa masalah.

Stakeholder perusahaan harus sepenuhnya memahami bagaimana saluran komunikasi hotline beroperasi dan bagaimana mereka akan dilindungi secara rahasia untuk penggunaannya. Kebijakan dan prosedur harus ada yang mengharuskan semua komunikasi melalui saluran hotline dinilai, diprioritaskan, dan diselidiki.

Prosedur eskalasi harus dilakukan untuk memastikan bahwa komunikasi hotline akan laporkan kepada anggota dewan kemudian dewan menunjuk, kepala audit internal, atau kepala etika melakukan penilaian yang tepat waktu, investigasi, dan tindakan yang tepat dilakukan. Mekanisme terpisah ini mendorong karyawan dan pemangku kepentingan untuk melaporkan dugaan pelanggaran kode etik perusahaan tanpa takut akan pembalasan, dan mengirim pesan yang jelas bahwa manajemen senior berkomitmen untuk membuka saluran komunikasi dan akan bertindak berdasarkan informasi yang dilaporkan kepadanya.

\section{Metode Komunikasi}

Bentuk-bentuk komunikasi aktif seperti pertemuan tatap muka sering kali lebih efektif daripada bentuk-bentuk pasif seperti broadcaste-mail atau posting Web. Evaluasi berkala terhadap efektivitas praktik komunikasi perusahaan membantu memastikan bahwa metode ini berfungsi. Komunikasi melalui tatap muka dilakukan untuk menilai berbagai proses yang ada, seperti evaluasi kinerja karyawan, tinjauan manajemen tahunan, dan program umpan balik. 
Manajemen harus memilih metode komunikasi yang tepat, dengan mempertimbangkan audiens, sifat komunikasi, ketepatan waktu, biaya, dan persyaratan keamanan dan privasi serta persyaratan hukum atau peraturan.

\section{Q. Prinsip Informasi dan Kommunicasi 15: Komunikasi Eksternal}

Prinsip COSO harus ditetapkan dan diterapkan oleh perusahaan adalah kebijakan dan prosedur yang memfasilitasi komunikasi eksternal yang efektif. Ini termasuk mekanisme untuk mendapatkan atau menerima informasi dari pihak eksternal dan untuk membagikan informasi itu secara internal, hal ini memungkinkan manajemen untuk mengidentifikasi tren, peristiwa, atau keadaan yang dapat mempengaruhi pencapaian tujuan pengendalian internal mereka.

Komunikasi manajemen dengan pihak eksternal harus mengirim pesan tentang;

a. Pentingnya pengendalian intern dalam perusahaan dengan menunjukkan jalur komunikasi terbuka.

b. Komunikasi dengan pemasok dan pelanggan eksternal sangat penting untuk membangun lingkungan pengendalian yang tepat untuk membantu pihak-pihak eksternal ini memahami nilai-nilai dan budaya perusahaan.

c. Hal-hal seperti kode etik perilaku organisasi dan mengakui tanggung jawab dalam membantu memastikan kepatuhan dengan ini dan nilai-nilai lainnya.

Masalah kompleksitas komunikasi dapat muncul antara perusahaan dan pihak eksternal melalui;

a. penyedia layanan dan pengaturan outsourcing,

b. usaha patungan dan aliansi, dan transaksi lainnya yang menciptakan saling ketergantungan antara pihak-pihak ini. 
Kompleksitas seperti itu dapat menimbulkan kekhawatiran tentang bagaimana bisnis dilakukan di antara para pihak. Dalam hal ini, perusahaan harus mempertimbangkan untuk membuat saluran komunikasi terpisah untuk penyedia layanan outsourcing agar mereka dapat berkomunikasi secara langsung dengan manajemen dan personil lainnya.

\section{R. Prinsip Pemantauan 16: Evaluasi Pengendalian Internal}

Kegiatan pemantauan menilai apakah tujuan pengendalian internal COSO ada dan berfungsi. Perusahaan harus menggunakan proses evaluasi yang sedang berlangsung untuk memastikan apakah prinsip-prinsip pengendalian internal yang ditetapkan, di seluruh perusahaan dan sub-unitnya berfungsi. Pemantauan adalah faktor kunci dalam penilaian efektivitas pengendalian internal. Suatu perusahaan, seringkali dengan dukungan audit internal, harus melakukan kegiatan pemantauan pengendalian yang berkelanjutan untuk mengidentifikasi dan mengkomunikasikan defisiensi pengendalian internal yang diketahui dalam proses pemantauan pengendalian intern.

Sebagai prinsip pengendalian utama, perusahaan harus memilih, mengembangkan, dan melakukan evaluasi untuk memastikan apakah komponen pengendalian internnya ada dan berfungsi. Pemantauan dapat dilakukan melalui beberapa kombinasi evaluasi atau proses pemantauan berkelanjutan. Audit internal dapat menjadwalkan tinjauan tunggal pada suatu area, berdasarkan penilaian risiko, dan kemudian dapat diulang untuk meninjau kembali area yang sama, berdasarkan defisiensi pengendalian internal yang ditemukan dalam review pertama.

Proses pemantauan berkelanjutan mirip dengan proses audit internal yang dilakukan untuk area yang memiliki risiko pengendalian tinggi. Evaluasi terhadap risiko tinggi yang terjadi 
pada operasi rutin dilakukan secara real-time, bereaksi terhadap perubahan kondisi. Dari hasil evaluasi kemudian dibangun suatu proses bisnis, dan komponen pengendalian internal yang memungkinkan sub-unit bisa memantau diri mereka sendiri secara berkelanjutan.

Pengendalian yang tidak dipantau cenderung memburuk seiring waktu, oleh sebab itu perusahaan harus menerapkan proses pemantauan untuk memastikan bahwa pengendalian internal terus beroperasi secara efektif. Ketika pemantauan dirancang dan dilaksanakan secara tepat, suatu perusahaan harus mendapat manfaat.

S. Prinsip Pemantauan 17: Mengkomunikasikan Defisiensi Pengendalian Internal

Suatu perusahaan harus mengkomunikasikan defisiensi pengendalian internnya secara tepat waktu kepada semua pihak yang bertanggung jawab untuk mengambil tindakan korektif, termasuk manajemen senior dan dewan direksi. Perusahaan harus mengidentifikasi hal-hal yang terkait dengan pemantauan yang patut mendapat perhatian yang mewakili kekurangan potensial atau nyata dalam beberapa aspek sistem pengendalian internal dan yang memiliki potensi untuk mempengaruhi kemampuan perusahaan untuk mencapai tujuannya. Selain itu, perusahaan harus berusaha mengidentifikasi peluang untuk meningkatkan efisiensi pengendalian internalnya.

Hasil evaluasi pemantauan yang sedang berlangsung harus dinilai berdasarkan kriteria manajemen untuk menentukan kepada siapa harus melaporkan dan apa yang akan dibahas. Semua defisiensi pengendalian intern yang diidentifikasi harus dikomunikasikan kepada manajemen untuk mengambil tindakan korektif tepat waktu. Setelah setiap defisiensi yang diidentifikasi 
dan dievaluasi, manajemen harus menentukan bahwa upaya remediasi dilakukan tepat waktu.

Defisiensi pengendalian internal, yang melintasi batas-batas organisasi, kekurangan harus dilaporkan kepada semua pihak yang relevan dan ke tingkat yang cukup tinggi untuk mendorong tindakan yang tepat. Kekurangan yang berkaitan dengan dewan direksi seperti;

a. dewan tidak independen sejauh yang disyaratkan

b. dewan tidak memberikan pengawasan yang memadai

Proses untuk melaporkan defisiensi pengendalian internal adalah komponen kunci untuk memastikan bahwa perusahaan memiliki pengendalian internal yang efektif. Manajemen perlu merancang, mengembangkan, dan meluncurkan proses pengendalian internal yang efektif disertai beberapa bentuk proses pemantauan untuk memberikan jaminan bahwa pengendalian intern tersebut sudah ada dan berjalan.

\section{T. Simpulan}

Bahwa memang, segala sesuatu pasti terjadi dan tergantung pada kekuatan kita berpikir dan sejauh mana visi masa depan yang diciptakan. Begitulah manusia yang memang punya "kuasa" dalam menjawab tantangan kebutuhan dan juga karena keterbatasan waktu. Manusia yang lambat berpikir dan lambat bekerja akan semakin tersingkirkan di kantor. Mereka yang lambat merespon kebutuhan pelanggan akan semakin mempercepat perusahaan untuk merealisasikan Industry 4.0. Bagaimana dengan 17 prinsip COSO tentu memerlukan perubahan behavior dan pentingnya waktu, juga manambah desakan untuk percepatanmya.

Dalam sebuah perusahaan, ada dua hal yang harus dipastikan terjadi, yakni mekanisme yang didesain dan behaviour yang terjadi dalam membentuk kultur. Mekanisme itu dimulai dari proses tone 
of the top, leadership dan efektifitas kontrol operasional. Kontrol operasional inilah yang sangat rumit. Tidak sesederhana yang ada dalam kertas atau semudah mengatakannya, karena kultur tidak tumbuh begitu saja. Risk Culture juga tidak tumbuh begitu saja, karena harus ada mekanisme tone of the top, visi dan missi yang kemudian ditransformasikan melaui proses objective setting. Objective setting ini akan diklarifikasi dengan risk appetite dan juga risk framework serta bagaimana kontrol operasionalnya.

Selanjutnya, apakah fungsi-fungsi yang ada siap untuk melakukan role dengan baik dan apakah people memiliki risk knowledge yang baik sehingga mereka mampu menyelaraskan perilaku yang berkinerja baik? Apakah fungsi (The Tree Line Defence) terlaksana dengan baik dan juga memiliki integritas yang diharapkan sesuai tingkat profesionalitas? Jika tidak, maka siap-siap energi terkuras. Jangankan kita berfikir tentang fraud, memikirkan proses yang kteatif untuk menciptakan efisensi saja pun sudah lebih dari cukup. Jangankan hal-hal besar, hal-hal kecil saja dulu identifikasi dan pikirkan nilainya. Mengharap mampu memikirkan hal-hal besar dengan menghayal tapi lupa untuk mengeksekusi hal kecil yang menjadi tanggung jawab.

\section{U. Contoh Kasus}

Pada Desember 2006 Indonesia Corruptin Watch (ICW) melaporkan kasus dugaan korupsi ke Komisi Pemberantasan Korupsi (KPK) dalam ruislaag (tukar guling) antara asset PT. Industri SandangNusantara (ISN), sebuah BUMN yang bergerak di bidang tekstil, dengan asset PT. GDC, sebuah perusahaan swasta.

Dalam ruislaag tersebut PT.ISN menukarkan tanah seluas 178.497 meter persegi di kawasan Senayan dengan Tanah seluas 47 hektar beserta Pabrik dan mesin di karawang. Berdasarkan hasil temuan Badan Pemeriksaan Keuangan (BPK) semester II Tahun Anggaran 
1998/1999, menyatakan ruislaag itu berpotensi merugikan keuangan Negara sebesar Rp. 121,628 miliar.

Kerugian itu terdiri dari kekurangan luas bangunan pabrik dan mesin milik PT. GDC senilai Rp. 63,954 miliar, berdasarkan penilaian aktiva tetap oleh PT. Sucofindo pada 1999; penyusutan nilai asset pabrik milik PT. GDC senilai Rp. 31,546 miliar; dan kelebihan perhitungan harga tanah senilai Rp. 0,127 miliar. Selain itu juga ditemukan bahwa terdapat nilai saham yang belum dibayarkan oleh PT. GDC sebesar Rp. 26 miliar.

\section{Solusi}

Dalam kasus Ruislaag di atas, karena ketidakjelasan prosedur dan syarat-syarat tukar guling asset, sehingga sangat rawan untuk diselewengkan.Seharusnya keputusan Tukar Guling tidak hanya menjadi wewenang salah satu pejabat saja, melainkan melibatkan beberapa pejabat sebagai pengendali dan control yang baik. Selain itu juga diperlukan sebuah aturan baku oleh perusahaan mengenai tukar guling, sehingga kemungkinan penyelewengan menjadi berkurang. Diperlukan juga control dari lembaga bersangkutan terhadap penelitian tim penilik yang meneliti kelengkapan mengenai status asset, dokumen kelengkapan asset, sehingga tidak ada manipulasi dari nilai asset tersebut serta proses tukar menukar. Walaupun menggunakan jasa Appraisal, penilaian asset tetap juga tetap harus diawasi untuk mencegah kecurangan-kecurangan.Dari kasus diatas dapat dibuktikan bahwa PT. ISN memiliki pengendalian intern yang sangat buruk.Sehingga PT. ISN rawan dicurangi oleh rekanan-rekanan bisnisnya maupun oleh oknum-oknum pejabat perusahaan yang ingin mengambil keuntungan. Oleh karena itu hal pertama yang harus dibenahi oleh PT. ISN adalah soal Pengendalian Internnya. 


\section{Pertanyaan untuk didiskusikan}

1. Jelaskan prinsip pengendalian internal COSO!

2. Jelaskan hubungan lingkungan pengendalian dengan dengan berbagai kebijakan etika di perusahaan!

3. Jelaskan prinsip penilaian risiko dalam sebuah perusahaan!

4. Berikan contoh aktivitas pengendalian yang harus dilakukan perusahaan!

5. Jelaskan prinsip monitoring pengendalian internal di perusahaan!

\section{Soal Kasus}

Strategic Indonesia mencatat, dalam kuartal I 2011 telah terjadi sembilan kasus pembobolan bank di berbagai industri perbankan. Jos Luhukay, pengamat Perbankan Strategic Indonesia, mengatakan, modus kejahatan perbankan bukan hanya soal penipuan (fraud), tetapi lemahnya pengawasan internal control bank terhadap sumber daya manusia juga menjadi titik celah kejahatan perbankan. "Internal control menjadi masalah utama perbankan. Bank Indonesia harus mengatur standard operating procedure (SOP)," kata Jos Luhukay, Senin (2/5/2011).

Berikut adalah sembilan kasus perbankan pada kuartal pertama yang dihimpun oleh Strategic Indonesia melalui Badan Reserse Kriminal Mabes Polri:

a. Pembobolan Kantor Kas Bank Rakyat Indonesia (BRI) Tamini Square. Melibatkan supervisor kantor kas tersebut dibantu empat tersangka dari luar bank. Modusnya, membuka rekening atas nama tersangka di luar bank. Uang ditransfer ke rekening tersebut sebesar 6 juta dollar AS. Kemudian uang ditukar dengan dollar hitam (dollar AS palsu berwarna hitam) menjadi 60 juta dollar AS.

b. Pemberian kredit dengan dokumen dan jaminan fiktif pada Bank Internasional Indonesia (BII) pada 31 Januari 2011. Melibatkan account officer BII Cabang Pangeran Jayakarta. Total kerugian Rp 3,6 miliar. 
c. Pencairan deposito dan melarikan pembobolan tabungan nasabah Bank Mandiri. Melibatkan lima tersangka, salah satunya customer service bank tersebut. Modusnya memalsukan tanda tangan di slip penarikan, kemudian ditransfer ke rekening tersangka. Kasus yang dilaporkan 1 Februari 2011, dengan nilai kerugian Rp 18 miliar.

Sumber : Kompas.com

Berdasarkan pemaparan berita diatas, sebagai mahasiwa yang sedang menempuh mata kuliah pengauditan internal, lakukan analisa kritis dan jawablah pertanyaan diskusi berikut:

1. Menurut saudara siapa yang seharusnya paling bertanggung jawab terhadap pelaksanaan internal control bank? Apakah pihak bank, Bank Indonesia atau kedua-duanya? Jelaskan.

2. Pengendalian internal apa saja yang telah dilanggar oleh bank tersebut diatas? dan apa yang menjadi motivasi terjadinya pelanggaran? Jelaskan

\section{Daftar Pustaka}

COSO Internal Control. (2013). Integrated Framework Principles. 2013

Gultom, J. (2019a). Fraud Risk Assessement. Dapat diunduh pada https://ionnyqultom.wordpress.com/2019/08/11/fraud-riskassessment/

https://na.theiia.org. (2018). https://na.theiia.org/standardsguidance/recommended-guidance/practice-guides/Pages/ Engagement-Planning-Assessing-Fraud-Risks.aspx

Moeller.R.R. (2016). Brink's Modern Internal Auditing Eighth Edition A Common Body of Knowledge Published by John Wiley \& Sons, Inc., Hoboken, New Jersey.

Sarbanes. (2010a). Amendments to the Act. made by the DoddFrank Wall Street Reform and Consumer Protection Act (July 21, 2010). 


\section{BAB 5}

\section{MENGELOLA RISIKO BISNIS: COSO ERM}

\section{Capaian Pembelajaran}

1. Mahasiswa mampu memahami COSO ERM: pengelolaan risiko bisnis.

2. Mahasiswa mampu memahami COSO ERM: komponen lingkungan internal.

3. Mahasiswa mampu memahami COSO ERM: pengaturan tujuan.

4. Mahasiswa mampu memahami COSO ERM: identifikasi peristiwa.

5. Mahasiswa mampu memahami COSO ERM: penilaian risiko.

6. Mahasiswa mampu memahami COSO ERM: respon risiko.

7. Mahasiswa mampu memahami COSO ERM: aktivitas pengendalian.

8. Mahasiswa mampu memahami COSO ERM: informasi dan komunikasi.

9. Mahasiswa mampu memahami COSO ERM: monitoring.

\section{A. Pendahuluan}

Dunia bisnis sempat terguncang dengan adanya kasus Enron yang terkuak pada akhir tahun 2001. Rekayasa keuangan dan malpraktik akuntansi tersebut ternyata juga diikuti oleh kasus-kasus sejenis seperti kasus WorldCom, Merck, dan lainnya. Salah satu faktor penting yang menjadi penyebabnya, menurut William C. Powers, Dekan Law School University of Texas adalah kelemahan sistem pengendalian internal dalam memitigasi risiko.

Menanggapi hal tersebut, Senat Amerika Serikat dalam kongresnya pada tanggal 23 Januari 2002 mengesahkan sebuah undang-undang perlindungan bagi para investor yang secara singkat 
disebut "Sarbanes-Oxley Act 2002" (Sarbanes, 2010a). Undangundang tersebut menjadi sangat penting karena sifatnya yang mengikat sebagai hukum positif. Melalui kewajiban yang mengikat tersebut, perhatian berbagai organisasi bisnis terhadap pengendalian internal, manajemen risiko, dan good governance berangsur-angsur meningkat. Meningkatnya perhatian terhadap pengendalian internal, manajemen risiko, dan tata kelola yang baik tersebut juga direspon oleh The Committee of Sponsoring Organizations of the Treadway Commission (COSO) dengan menerbitkan Enterprise Risk Management ("ERM") Integrated Framework pada bulan September 2004 (COSO, 2017b).

COSO-ERM adalah suatu kerangka kerja untuk membantu perusahaan dalam memperhitungkan risiko yang sedang mereka hadapi. Enterprise risk management sendiri memiliki arti sebuah proses, yang dipengaruhi oleh dewan direksi, manajemen dan personil lainnya, diterapkan dalam pengaturan strategi di seluruh perusahaan, yang dirancang untuk mengidentifikasi kejadian potensial yang dapat mempengaruhi perusahaan, dan mengelola risiko hingga berada dalam risiko yang dapat diterima, untuk memberikan keyakinan memadai sehubungan dengan pencapaian tujuan perusahaan (Moeller.R.R. 2016).

Dalam praktik nyata auditor internal, tak ada batas hitam putih yang memisahkan tugas penjaminan dan konsultasi. Mungkin saja penjaminan dan konsultasi menjadi campuran (blended) dalam satu penugasan. Suatu aktivitas reviu atau evaluasi oleh auditor internal bisa saja di dalamnya mengandung unsur penjaminan dan konsultasi. Jika jelas bagian mana yang masuk penjaminan dan bagian mana yang masuk konsultasi, pelaporan keduanya diharapkan terpisah (Moeller.R.R. 2016).

\section{B. COSO ERM: Pengelolaan Risiko Bisnis}


Auditor harus mempertimbangkan pokok-pokok dan konsepkonsep kunci yang mendukung definisi kerangka kerja ERM COSO, termasuk:

a. COSO ERM adalah serangkaian langkah terdokumentasi untuk meninjau dan mengevaluasi risiko potensial dan untuk mengambil tindakan berdasarkan berbagai faktor di seluruh perusahaan.

b. Proses ERM dilaksanakan oleh orang-orang di perusahaan. Proses manajemen risiko harus dikelola oleh orang-orang yang cukup dekat dengan situasi risiko untuk memahami berbagai faktor di sekitar risiko itu, termasuk implikasinya.

c. ERM diterapkan melalui pengaturan strategi di seluruh perusahaan. Perangkat ERM yang efektif harus memainkan peran utama dalam membantu membangun strategi alternatif. Karena banyak perusahaan besar, dengan unit operasi yang bervariasi, ERM harus diterapkan di seluruh perusahaan menggunakan jenis pendekatan portofolio yang memadukan campuran aktivitas berisiko tinggi dan rendah.

d. Selera risiko perusahaan harus dipertimbangkan. Selera risiko dapat diukur dalam arti kualitatif dengan melihat risiko dalam kategori seperti tinggi, sedang, atau rendah.

e. ERM hanya memberikan kepastian yang masuk akal, tidak positif, untuk pencapaian yang objektif. Bahwa ERM, tidak peduli seberapa baik diterapkan, tidak dapat memberikan jaminan kepastian hasil kepada manajemen.

f. ERM dirancang untuk membantu mencapai pencapaian tujuan. Suatu perusahaan, melalui manajemennya, harus bekerja untuk menetapkan tujuan bersama mencakup hal-hal seperti mencapai dan mempertahankan reputasi positif dalam bisnis dan komunitas konsumen perusahaan, menyediakan 
pelaporan keuangan yang dapat diandalkan untuk semua pemangku kepentingan, dan beroperasi sesuai dengan hukum dan peraturan (COSO Internal Control, 2013).

\section{c. Elemen COSO ERM Utama}

Kerangka kerja COSO ERM ini ditunjukkan dalam Gambar 5.1 sebagaisebagai berikut:

a. Tujuan strategis risiko perusahaan diwakili oleh strategi, operasional, pelaporan dan kepatuhan;

b. Terdapat delapan komponen risiko, dan

c. Risiko bisa berada pada setiap level dalam perusahaan.

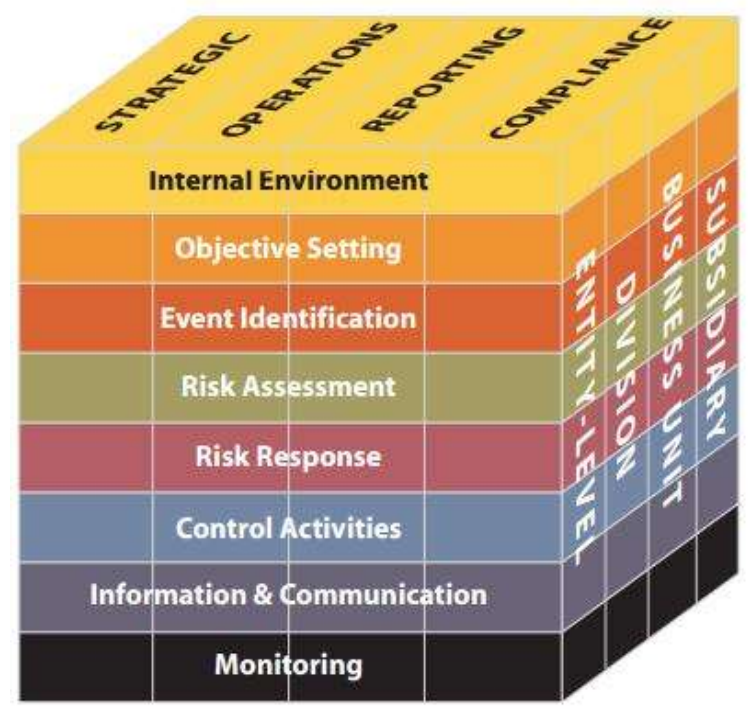

Gambar 5.1 COSO ERM Framework

Sumber : (COSO Internal Control, 2013)

Konsep di balik kerangka kerja ERM adalah menyediakan model bagi perusahaan untuk mempertimbangkan dan memahami aktivitas terkait risiko di semua tingkatan serta 
bagaimana komponen risiko ini saling mempengaruhi. COSO ERM memiliki tujuan dan kegunaan yang berbeda dengan kerangka kerja pengendalian internal COSO.

\section{Komponen Lingkungan Internal : COSO ERM}

Lingkungan internal harus dianggap sebagai batu penjuru untuk COSO ERM. Tingkat ini mendefinisikan dasar untuk semua komponen lain dalam model ERM perusahaan, mempengaruhi bagaimana strategi dan tujuan harus ditetapkan, bagaimana aktivitas bisnis terkait risiko disusun, dan bagaimana risiko diidentifikasi dan ditindaklanjuti.

Komponen lingkungan internal COSO ERM terdiri dari elemen-elemen berikut (COSO Internal Control, 2013):

a. Filosofi manajemen risiko. Sikap dan keyakinan bersama yang menjadi ciri bagaimana perusahaan mempertimbangkan risiko dalam segala hal yang dilakukannya.

b. Selera berisiko. Selera risiko adalah jumlah risiko yang bersedia diterima perusahaan dalam mengejar tujuannya.

c. Sikap dewan direksi. Dewan dan komitenya memiliki peran yang sangat penting dalam mengawasi dan membimbing lingkungan risiko perusahaan.

d. Nilai integritas dan etika. Mencakup pernyataan misi yang dipikirkan dengan matang dan standar integritas.

e. Komitmen terhadap kompetensi. Kompetensi mengacu pada pengetahuan dan keterampilan yang diperlukan untuk melakukan tugas.

f. Struktur organisasi. Suatu perusahaan harus mengembangkan struktur organisasi dengan garis 
wewenang, tanggung jawab, dan pelaporan yang sesuai.

g. Penugasan wewenang dan tanggung jawab. Komponen ERM ini mengacu pada sejauh mana derajat wewenang dan tanggung jawab ditugaskan atau didelegasikan.

h. Standar sumber daya manusia. Praktik mengenai perekrutan karyawan, pelatihan, kompensasi, promosi, pendisiplinan, dan semua tindakan lainnya mengirim pesan mengenai apa yang disukai, ditoleransi, atau dilarang.

Dua komponen lingkungan internal COSO ERM, filosofi manajemen risiko perusahaan dan selera relatifnya terhadap risiko, memberi asupan pada elemen-elemen lain dari kerangka kerja COSO ERM (COSO, 2017b). Sementara filosofi manajemen risiko dapat dipertimbangkan dalam hal sikap dewan direksi dan kebijakan sumber daya manusia, antara lain, risk appetite seringkali merupakan ukuran yang lebih lunak di mana perusahaan telah menentukan akan menerima beberapa risiko tetapi menolak yang lain terkait kemungkinan terjadinya risiko. dan dampak risiko.

\section{Pengaturan Tujuan; COSO ERM}

Selain lingkungan internal yang efektif, perusahaan harus menetapkan serangkaian tujuan strategis, tujuan operasional, penganggaran, aktivitas operasi, pelaporan, dan kepatuhan (COSO Internal Control, 2013).

Perusahaan harus menetapkan rentang risiko yang dapat diterima di banyak bidang. Misalnya, produk yang keluar dari jalur produksi mungkin memiliki tingkat kesalahan tidak lebih besar dari $0,005 \%$. Itu adalah tingkat kesalahan yang sangat 
rendah di banyak bidang, tetapi tetap saja manajemen akan menerima risiko klaim garansi produk atau kerusakan jika ada kesalahan walau dalam batas yang relatif sempit itu.

Untuk mengelola dan mengendalikan risiko di semua tingkatan, suatu perusahaan perlu menetapkan tujuannya dan menetapkan toleransinya karena harus terlibat dalam praktik berisiko dan kepatuhannya terhadap peraturan.

\section{Identifikasi Peristiwa ; COSO ERM}

Peristiwa adalah insiden atau kejadian bersumber dari internal atau eksternal, yang mempengaruhi implementasi strategi ERM dan pencapaian tujuannya. Banyak perusahaan saat ini memiliki alat pemantauan kinerja yang kuat, seperti; pemantauan biaya, anggaran, jaminan kualitas, kepatuhan, dan sejenisnya.Proses pemantauan harus mencakup:

a. Peristiwa ekonomi eksternal. Berbagai peristiwa eksternal perlu dipantau untuk membantu mencapai tujuan ERM perusahaan.

b. Kejadian lingkungan alam.Banyak peristiwa dapat menjadi insiden dalam identifikasi risiko ERM yang bersumber dari kejadian alam.

c. Peristiwa politik. Undang-undang dan peraturan baru serta beberapa hasil pemilu dapat menjadi dampak yang berhubungan dengan peristiwa risiko yang signifikan pada perusahaan.

d. Faktor sosial. Sebagian besar faktor sosial perlahan berkembang. Ini termasuk perubahan demografis, adat istiadat sosial, dan peristiwa lain yang dapat mempengaruhi suatu perusahaan dan pelanggannya dari waktu ke waktu. 
e. Kejadian infrastruktur internal. Perusahaan yang sering melakukan perubahan memicu peristiwa terkait risiko lainnya..

f. Kejadian proses internal. Perubahan proses utama dapat memicu berbagai peristiwa pengidentifikasian risiko.

g. Perubahan teknologi eksternal dan internal. Setiap perusahaan menghadapi berbagai macam peristiwa teknologi yang dapat memicu kebutuhan untuk identifikasi risiko formal.

Perusahaan perlu secara jelas mendefinisikan peristiwaperistiwa risiko yang signifikan dan kemudian memiliki proses untuk memonitornya agar dapat mengambil tindakan seperlunya. Melihat peristiwa risiko internal potensial dan eksternal dan memutuskan mana yang memerlukan perhatian lebih lanjut dapat menjadi proses yang sulit. Materi pendukung COSO ERM menyarankan bahwa perusahaan harus menetapkan proses untuk meninjau risiko yang berpotensi signifikan dan kemudian mempertimbangkan beberapa pendekatan berikut:

a. Daftar peristiwa. Manajemen harus mengembangkan daftar peristiwa yang berhubungan dengan risiko yang umum terjadi pada industri spesifik perusahaan dan bidang fungsional.

b. Lokakarya yang difasilitasi. Suatu perusahaan dapat mengadakan lokakarya lintas fungsional untuk membahas faktor risiko potensial yang dapat berkembang dari berbagai peristiwa internal atau eksternal. Ini dapat menghasilkan rencana tindakan untuk memperbaiki potensi risiko.

c. Wawancara, kuesioner, dan survei. Informasi mengenai peristiwa risiko potensial dapat berasal dari berbagai 
sumber, seperti surat kepuasan pelanggan atau wawancara karyawan yang keluar.

d. Pemicu peristiwa. Menetapkan serangkaian pengukuran unit bisnis untuk memantau toleransi risiko dan membuat tindakan perbaikan.

e. Pelacakan data peristiwa hilang. Pelacakan peristiwa kerugian mengacu pada penggunaan sumber basis data internal dan publik untuk melacak aktivitas di bidang yang diminati.

Alat dan pendekatan pengidentifikasian risiko yang baru saja dibahas dapat menghasilkan beberapa informasi yang sangat berharga dan berguna bagi perusahaan yang mengidentifikasi risiko dan peluang.

\section{Penilaian Risiko COSO ERM}

Komponen penilaian risiko adalah inti kerangka kerja ERM. Penilaian risiko mendorong perusahaan untuk mempertimbangkan dampak dari setiap peristiwa yang terkait dengan risiko secara keseluruhan terhadap pencapaian tujuan perusahaan. Risiko-risiko ini harus dinilai dari dua perspektif (COSO, 2017a):

a. kemungkinan terjadinya risiko, dan

b. potensi dampaknya.

Bagian penting dari proses penilaian risiko adalah kebutuhan untuk mempertimbangkan konsep yang sangat penting dari risiko inheren dan residual:

a. Risiko inheren. merupakan "potensi pemborosan, kehilangan, penggunaan yang tidak sah, atau penyalahgunaan karena sifat suatu aktivitas itu sendiri." Faktor utama yang mempengaruhi risiko inheren pada perusahaan adalah ukuran anggaran, kekuatan dan 
kecanggihan manajemen, dan sifat aktivitasnya. Risiko inheren ada di luar pengendalian manajemen dan biasanya berasal dari faktor eksternal.

b. Risiko residual. adalah risiko yang tersisa setelah respons manajemen terhadap ancaman dan tindakan pencegahan risiko telah diterapkan. Selahu ada beberapa tingkat risiko residual.

Perusahaan selalu menghadapi beberapa campuran antara risiko inheren dan residual. Setelah manajemen mengatasi risiko dari proses identifikasi risiko, mereka masih memiliki beberapa risiko residual untuk diperbaiki. Perusahaan dapat mengambil beberapa langkah mengurangi risiko inheren yang terkait dengan pasar atau proses bisnis tetapi pada dasarnya tidak dapat melakukan apa pun terkait risiko inheren dari bencana alam besaryang menimpa area penting operasinya.

Kemungkinan terjadinya risiko dan dampak risiko adalah dua komponen penting yang diperlukan untuk melakukan penilaian risiko. Kemungkinan terjadinya risiko adalah probabilitas bahwa risiko akan terjadi yang dinyatakan dalam kemungkinan risiko tinggi, sedang, atau rendah. Ada beberapa metode kuantitatif untuk mengembangkan estimasi kemungkinan terjadinya risiko.

Beberapa peristiwa risiko dapat menyebabkan dampak kecil tetapi tidak dapat dipulihkan oleh suatu perusahaan. Tetapi ada juga risiko dampak kecil bisa menjadi bencana. Konsep di balik ERM bukan untuk mengembangkan perhitungan tingkat aktuaria yang tepat mengenai risiko-risiko tetapi untuk menyediakan kerangka kerja manajemen risiko yang efektif. Perhitungan terperinci terkait kerugian risiko dapat di delegasikan kepada penaksir asuransi dan lainnya. 
Analisis kemungkinan terjadinya risiko dan dampak potensial dapat dikembangkan dengan metode kuantitatif dan kualitatif. Untuk menilai semua risiko yang diidentifikasi dan memeringkatnya dalam hal kemungkinan terjadinya risiko dan dampak risiko secara konsisten.

Mengevaluasi setiap risiko yang mungkin berdampak pada berbagai tujuan, mempertimbangkan kemungkinan terjadinya risiko dan dampak risiko potensial, mempertimbangkan keterkaitan risiko pada unit-per-unit atau perusahaan secara keseluruhan, dan kemudian mengembangkan strategi untuk respon yang sesuai. COSO ERM menyarankan bahwa perusahaan harus mengambil pendekatan total, di semua unit dan semua masalah strategis utama, untuk mengidentifikasi risiko secara konsisten dan menyeluruh.

\section{Elemen Respon Risiko; COSO ERM}

Setelah mengidentifikasi dan menilai risiko yang signifikan, proses respons risiko COSO ERM meminta peninjauan yang cermat terhadap kemungkinan terjadinya risiko dan dampak potensial, dengan pertimbangan biaya dan manfaat yang terkait untuk mengembangkan strategi respons risiko yang tepat, Terdapat empat strategi risiko dasar yang dilakukan diantaranya:

a. Penghindaran.Strategi untuk menjauh dari risiko seperti menjual unit bisnis yang menimbulkan risiko, relokasi perusahaan, atau menghentikan lini produk.

b. Pengurangan. Manajemen harus mengambil keputusan bisnis untuk mengurangi risiko tertentu.

c. Berbagi. Secara teratur berbagi sebagian risiko melalui pembelian asuransi, dan teknik pembagian risiko lainnya juga tersedia. 
d. Penerimaan.Perusahaan harus melihat kemungkinan risiko dan dampaknya sehubungan dengan toleransi risiko yang telah ditetapkan dan kemudian memutuskan apakah akan menerima risiko atau tidak.

Manajemen harus mengembangkan strategi respons umum untuk setiap risiko yang dibangun dari satu atau campuran dari strategi risiko. Dalam melakukan hal itu, perusahaan harus mempertimbangkan biaya versus manfaat dari setiap respons risiko potensial serta strategi yang paling sesuai dengan selera risiko perusahaan.

Mengembangkan respons risiko memerlukan sejumlah besar perencanaan dan pemikiran strategis. Beberapa alternatif respons risiko mungkin melibatkan biaya, waktu, dan perencanaan proyek yang terperinci. Bahwa semua risiko yang terdaftar pada analisis harus diukur terhadap faktor dampak yang sama, berdasarkan strategi risiko penerimaan, hindari, berbagi, atau kurangi.

\section{Aktivitas Pengendalian; ERM COSO}

Aktivitas pengendalian ERM adalah kebijakan dan prosedur yang diperlukan untuk memastikan tindakan pada respons risiko yang teridentifikasi.

Setelah memilih respons risiko yang tepat, suatu perusahaan harus memilih aktivitas pengendalian yang diperlukan untuk memastikan bahwa respon risiko dilaksanakan dengan tepat waktu dan efisien. Setelah melalui proses identifikasi, penilaian, dan proses respons risiko dengan langkah-langkah berikut:

a. Mengembangkan pemahaman yang kuat tentang risiko signifikan dan menetapkan prosedur pengendalian untuk memantau atau memperbaiki risiko tersebut. 
b. Buat prosedur pengujian untuk menentukan apakah prosedur pengendalian terkait risiko tersebut bekerja secara efektif.

c. Lakukan tes proses pemantauan risiko untuk menentukan apakah kebijakan dan prosedur bekerja secara efektif dan seperti yang diharapkan.

d. Lakukan penyesuaian atau perbaikan seperlunya untuk meningkatkan proses pemantauan risiko.

Proses empat elemen ini mencakup langkah-langkah untuk meninjau, menguji, dan kemudian menegaskan bahwa proses pengendalian internal berfungsi dengan baik. Karena sifat kritis dari risiko bagi perusahaan, pemantauan risiko menjadi sangat penting bagi kesehatan perusahaan secara keseluruhan. Banyak aktivitas pengendalian di bawah kendali internal cOSO cukup mudah untuk diidentifikasi dan diuji karena sifat pengendalian internal akuntansi umumnya mencakup bidang-bidang berikut:
a. Pemisahan tugas.
b. Jalur audit.
c. Keamanan dan integritas.
d. Dokumentasi.

Prosedur pengendalian ini berlaku untuk semua proses pengendalian internal dalam perusahaan dan juga berlaku untuk banyak peristiwa yang berkaitan dengan risiko.

\section{Informasi dan Komunikasi; COSO ERM}

Komponen COSO ERM informasi dan komunikasi merupakan rangkaian terpisah dari proses terkait risiko yang menghubungkan komponen ERM COSO lainnya. Misalnya, komponen respons risiko menerima input risiko residual dan inheren dari penilaian risiko serta dukungan toleransi risiko dari komponen penetapan tujuan. Respon risiko ERM kemudian 
memberikan respons risiko dan data portofolio risiko untuk mengontrol aktivitas serta umpan balik untuk penilaian risiko.Walaupun, komponen pemantauan tidak memiliki koneksi informasi langsung tetapi memiliki tanggung jawab keseluruhan untuk meninjau semua fungsi ini.

Karena banyak perusahaan memiliki jaringan kompleks yang seringkali tidak terhubung dengan baik dengan sistem informasi keuangan dan operasional untuk proses dasar. Keterkaitan ini menjadi lebih kompleks untuk banyak proses ERM mengingat banyak aplikasi dasar perusahaan tidak secara langsung terkait dengan identifikasi risiko, penilaian, dan proses tipe respons risiko.

Ada kebutuhan untuk mengembangkan pemantauan risiko dan sistem komunikasi yang terhubung dengan pelanggan, pemasok, dan pemangku kepentingan lainnya. Perlunya mekanisme untuk memastikan bahwa semua pemangku kepentingan menerima pesan mengenai minat perusahaan dalam mengelola risikonya.

Komponen utama dari pesan komunikasi ini adalah penggunaan bahasa risiko umum di seluruh perusahaan mengenai peran dan tanggung jawab semua pemangku kepentingan terkait peran manajemen risiko.

\section{Pemantauan; ERM COSO}

Pemantauan ERM diperlukan untuk menentukan bahwa semua komponen ERM yang ditetapkan bekerja secara efektif. Orang-orang dalam suatu perusahaan dapat berubah, proses pendukung dan kondisi internal maupun eksternal dapat berubah, tetapi komponen pemantauan membantu memastikan bahwa ERM bekerja efektif secara berkelanjutan dan tetap konsisten. Untuk membangun kerangka kerja ERM yang efektif, 
pemantauan harus mencakup tinjauan berkelanjutan dari keseluruhan proses ERM mulai dari diidentifikasi hingga kemajuan aktivitas pengendalian ERM yang sedang berlangsung, pemantauan ERM termasuk jenis aktivitas berikut:

a. Implementasi mekanisme pelaporan manajemen yang sedang berlangsung. Perusahaan tidak harus menunggu sampai akhir tahun fiskal untuk jenis-jenis laporan status ini, dan laporan kilat respons cepat harus dimulai.

b. Proses pelaporan waspada terkait risiko berkala yang memantau aspek-aspek kunci dari kriteria risiko yang ditetapkan, termasuk tingkat kesalahan yang dapat diterima.

c. Pelaporan status terkini dan berkala dari temuan dan rekomendasi terkait risiko dari laporan audit internal dan eksternal.

d. Informasi terkini yang terkait risiko dari sumber-sumber seperti peraturan yang direvisi pemerintah, tren industri, dan berita ekonomi secara umum. Jenis pelaporan ekonomi dan operasional ini harus tersedia untuk manajer di semua tingkatan

Pemantauan evaluasi terpisah atau individual mengacu pada tinjauan terperinci atas proses risiko individual oleh audit internal. Di sini peninjauan dapat dibatasi pada area spesifik atau mencakup seluruh proses ERM untuk unit perusahaan, dan audit internal sering kali merupakan sumber internal terbaik untuk melakukan tinjauan ERM spesifik tersebut.

\section{Dimensi Lain dari COSO ERM: Tujuan Risiko Bisnis}

Komponen menghadap atas terdiri dari tujuan strategis, operasi, pelaporan, dan risiko kepatuhan penting untuk dipahami dan diterapkan ERM COSO. 


\section{Tujuan Pengelolaan Risiko Operasional}

Ada banyak jenis risiko operasi yang dapat berdampak pada perusahaan. Dalam kerangka ERM tiga dimensi, tujuan pengelolaan risiko tingkat operasi memerlukan identifikasi risiko untuk setiap unit dalam perusahaan. Identifikasi risiko operasi ini sering kali memerlukan pengumpulan informasi dan analisis, lini produk, atau proses bisnis. Untuk mengumpulkan informasi latar belakang yang lebih rinci tentang potensi risiko operasi, informasi seringkali dikumpulkan melalui tinjauan audit internal atau survei manajer yang terkena dampak langsung dari risiko ini. Survei bisa dilakukan pada staf dengan beberapa pertanyaan yang diajukan di sini mirip dengan jenis pertanyaan terperinci yang sering digunakan dalam penilaian pengendalian internal, dan hasil dari setiap data yang tersedia dapat menjadi dasar untuk mengembangkan pemahaman yang lebih baik tentang potensi risiko operasional.

Apapun level dalam hierarki organisasi atau lokasi geografis, manajer di semua level harus menyadari bahwa mereka bertanggung jawab untuk menerima dan mengelola risiko dalam unit operasional mereka sendiri. Pentingnya COSO ERM dan pengelolaan risiko operasi harus dikomunikasikan ke semua tingkatan perusahaan. Auditor internal harus bertindak sebagai mata dan telinga serta melaporkan semua risiko operasi yang diamati. Hal ini bisa dilakukan jika auditor internal merencanakan audit mengikuti dinamika bisnis sehingga terus mutakhir sesuai dengan turbulensi dan kecepatan dinamika bisnis beserta risikonya ( Moeller, R. R. 2016).

\section{Tujuan Melaporkan Pengelolaan Risiko.}

Tujuan ERM ini mencakup keandalan pelaporan suatu perusahaan, termasuk pelaporan internal dan eksternal dari 
data keuangan dan nonkeuangan. Pelaporan yang akurat sangat penting untuk keberhasilan suatu perusahaan. Sering ada temuan pelaporan keuangan perusahaan yang tidak akurat dapat menyebabkan masalah di banyak bidang. Apapun industrinya, perusahaan menghadapi risiko besar dari pelaporan yang tidak akurat di unit atau area mana pun. Unit-unit operasi harus memastikan bahwa hasil yang dilaporkan adalah benar sebelum diteruskan ke tingkat berikutnya dalam organisasi, dan angka yang terkonsolidasi harus akurat, untuk laporan keuangan, laporan pajak, atau laporan lainnya. Sementara pengendalian internal yang baik diperlukan untuk memastikan pelaporan yang akurat. Pengendalian internal yang kuat harus meminimalkan risiko kesalahan, dan perusahaan harus selalu mempertimbangkan risiko yang terkait dengan pelaporan yang tidak akurat. Kesalahan kecil tidak dapat diabaikan dari waktu ke waktu sebelum menjadi kesalahan besar yang perlu diungkapkan.

\section{Tujuan Risiko Kepatuhan Hukum dan Peraturan}

Perusahaan dalam bentuk apa pun harus mematuhi berbagai undang-undang dan peraturan yang diberlakukan pemerintah atau industri. Sementara risiko kepatuhan dapat dipantau, karena risiko hukum terkadang sama sekali tidak terduga. Terdapat beberapa jenis risiko hukum yang sangat sulit diantisipasi tetapi dapat menimbulkan bencana bagi perusahaan. COSO ERM merekomendasikan agar risiko terkait kepatuhan dipertimbangkan untuk masing-masing komponen kerangka risiko, baik dalam konteks lingkungan internal, penetapan tujuan, atau pemantauan risiko di seluruh perusahaan. Semua perusahaan menghadapi berbagai persyaratan kepatuhan hukum dan peraturan,. Sifat risiko 
kepatuhan tersebut perlu dikomunikasikan dan dipahami melalui semua tingkatan perusahaan.

Untuk mengelola dan menetapkan tujuan risiko hukum dan peraturan, dewan direksi, CEO dan anggota manajemen perlu memiliki pemahaman tentang sifat dan tingkat semua risiko hukum dan peraturan yang dihadapi perusahaan.

\section{E. Risiko Tingkat Entitas}

Kerangka kerja COSO ERM menunjukkan empat divisi dalam dimensi kerangka kerja ini yaitu: tingkat entitas, divisi, unit bisnis, dan risiko anak perusahaan. Risiko harus diidentifikasi dan dikelola di dalam setiap unit organisasi, termasuk risiko berdasarkan entitas secara luas melalui unit bisnis individu. Perusahaan dengan empat divisi operasi utama dan dengan beberapa unit bisnis atau unit anak perusahaan di bawahnya masing-masing memiliki kerangka kerja ERM. Sebaliknya, manajemen harus mendefinisikan risiko tingkat organisasi pada tingkat rinci yang mencakup semua risiko penting yang dapat dikelola.

\section{Risiko Meliputi Seluruh Organisasi}

Beberapa risiko pada tingkat unit bisnis harus digabungkan menjadi risiko tingkat perusahaan. Meskipun mudah bagi perusahaan untuk mengabaikan beberapa risiko tingkat unit yang tidak material dan terjadi pada anak perusahaan yang relatif kecil. Pertimbangan mengabaikan karena anak perusahaan tersebut sangat kecil kontribusi pendapatannya pada tingkat perusahaan. Risiko besar dan tampaknya kecil dapat berdampak pada keseluruhan perusahaan. Walaupun relatif mudah untuk mengidentifikasi risiko tingkat entitas, terkadang risiko potensial yang kecil selip di antara celah-celah. Risiko diidentifikasi melalui penetapan tujuan organisasi secara keseluruhan, risiko tersebut harus dipertimbangkan 
berdasarkan entitas secara luas maupun oleh unit operasi individu. Risiko masing-masing unit tersebut harus ditinjau dan dikonsolidasikan terlebih dahulu untuk mengidentifikasi risiko utama yang dapat berdampak pada keseluruhan organisasi.

\section{Risiko Tingkat Unit Bisnis}

Risiko yang signifikan harus dipertimbangkan dalam setiap unit organisasi. Risiko yang diidentifikasi pada anak perusahaan harus digabung hingga ke keseluruhan entitas. Bergantung pada kompleksitas dan jumlah unit operasi, manajemen tingkat perusahaan secara resmi menjabarkan masalah risiko utama dan meminta manajemen yang bertanggung jawab di setiap divisi untuk mensurvei tujuan risiko. Dengan cara ini, risiko yang signifikan dapat diidentifikasi di semua tingkatan dan kemudian dikelola di tingkat regional. Konsep utama COSO ERM adalah perusahaan menghadapi berbagai risiko signifikan di semua tingkatan, beberapa mungkin signifikan, sementara yang lain hanya bersifat mengganggu dan dianggap kecil.

\section{F. Risiko Audit dan Proses ERM}

Kerangka kerja COSO dan kerangka kerja ERM COSO menguraikan pendekatan manajemen risiko berlaku untuk semua industri dan mencakup semua jenis risiko. Dengan fokusnya pada mengenali selera perusahaan terhadap risiko, kebutuhan untuk melihat keseluruhan portofolio risiko, dan kebutuhan untuk menerapkan manajemen risiko dalam konteks pengaturan strategi keseluruhan, COSO ERM menyediakan platform yang sangat baik untuk mempertimbangkan lingkungan risiko perusahaan secara keseluruhan.

Auditor internal menghadapi masalah pengelolaan risiko di banyak bidang tinjauan dan analisis audit, dan auditor internal yang efektif harus memahami proses pengelolaan risiko. 
Seringkali, auditor internal melakukan tinjauan pengendalian internal di beberapa area yang dipilih atau tidak dipilih berdasarkan pertimbangan risiko. Auditor internal harus memiliki tingkat pemahaman dasar tentang proses pengelolaan risiko untuk dapat mengajukan pertanyaan yang tepat dan meninjau kecukupan proses pengelolaan risiko tersebut.

Dengan fokus pada kerangka ERM COSO serta praktik pengelolaan risiko yang baik, auditor internal dapat memberikan layanan kepada perusahaan dengan merencanakan dan melakukan tinjauan proses pengelolaan risiko tingkat perusahaan. Selain itu, setiap tinjauan audit internal atas proses ERM perusahaan harus direncanakan melalui pendekatan audit internal berbasis risiko dengan menggunakan beberapa alat berikut:

a. Proses bagan alur. Sebagai bagian dari proses ERM apa pun yang diidentifikasi dari diagram alir proses bisnis dapat berguna dalam menggambarkan bagaimana pengelolaan risiko berjalan di suatu perusahaan.

b. Tinjauan risiko dan bahan pengendalian. Proses ERM menghasilkan bahan panduan, prosedur terdokumentasi, format laporan, untuk meninjau risiko dan bahan pengendalian dari perspektif efektivitas.

c. Pembandingan. Proses melihat fungsi di lingkungan lain untuk menilai operasi mereka dengan praktik terbaik dari orang lain.

d. Kuisioner. Metode yang baik untuk mengumpulkan informasi tentang keefektifan ERM dari berbagai orang.

Auditor internal harus menggunakan prinsip-prinsip pengelolaan risiko ketika memutuskan area audit dan kemudian menggunakan prinsip-prinsip risiko ketika menilai bukti audit. 
Auditor internal harus memahami ERM COSO baik untuk mengaudit kepatuhan maupun berkonsultasi dengan manajemen untuk memastikan implementasi yang lebih efektif

\section{G. Simpulan}

Jika sebelumnya terbiasa lelet dan tak suka melakukan analisis data maka dalam era Industry 4.0 harus bisa cekatan untuk melakukan data gathering, analisis data dan bahkan melakukan uji data secara statistik. Uji data ini bisa untuk mengambil kesimpulan bahwa proses yang dilakukan mesin atau aplikasi sudah valid atau terdapat risiko dan risiko tersebut perlu disiapkan kontrol yang lebih baik dari kontrol yang ada.

Dalam situasi bisnis yang kompleks, interpretasi terhadap pengendalian harus bersifat komprehensif. Ada suatu sistem yang saling interdependen. COSO Internal Control Framework sangat detail dan sangat baik dalam memberikan uraian mengenai ini. Setiap elemen memiliki core values yang harus diterapkan dan aplikasinya akan disesuaikan dengan kompleksitas dan kultur perusahaan.

Dalam konsep yang lebih luas, coso juga telah mengembangkan Enterprises wide Risk Management Framework dan apabila dinalar lebih detail maka ERM ini juga merupakan perluasan hubungan antara konsep Internal Control dan Risk Management Framework.

Kompleksitas sudah menjadi menu setiap hari bagi perusahaan. Kompleksitas ini sangat dipengaruhi oleh variabel kompetisi bisnis akibat kelangkaan (scarcity). Karena faktor kompleksitas ini, para pelaku bisnis yang kurang hati-hati sehingga sangat tinggi probabilitas terpapar risiko tertentu karena belum ada tahapan-tahapan proses risk management yang baik (termasuk proses evaluasi ketersediaan kontrol yang 
cukup). Internal Auditor adalah pihak independen yang melakukan melakukan fungsi assurance dan consulting terhadap efektifitas proses dari sistem kontrol, manajemen risiko dan tata kelola.

\section{H. Contoh Kasus}

Dalam dunia bisnis, lanskap yang berkembang ini berarti risiko terkait lingkungan, sosial dan tata kelola yang dulunya dianggap sebagai "angsa hitam" kini jauh lebih umum - dan dapat terwujud lebih cepat dan signifikan. Sebuah laporan dari Society for Corporate Governance.

Ilustrasi JBS adalah perusahaan daging terbesar di dunia berdasarkan pendapatan, kapasitas, dan produksi unggas, domba, dan babi. Dimulai pada akhir 2015 dan berlanjut hingga Juni 2017, tuduhan berturut-turut tentang kontaminasi daging, korupsi, penggundulan hutan, kerja paksa, dan penipuan diajukan terhadap JBS sebagai bagian dari beberapa penyelidikan ekstensif dan berkelanjutan yang berpusat pada industri pengepakan daging, dan JBS pada khususnya. Pada akhirnya, JBS menghadapi dampak finansial material, termasuk hilangnya nilai ekuitas sebesar 31\%. Meskipun dampak paling langsung berasal dari tata kelola yang lemah, tantangan tersebut diperparah oleh serangkaian tantangan terkait lingkungan, sosial dan tata kelola yang kompleks dan saling terkait, yang tercermin dalam penurunan minat investor dan konsumen di pasar internasional yang memprioritaskan perhatian lingkungan, sosial dan tata kelola.

\section{Solusi}

Dalam konsep budaya dan pengendalian yang kuat dan ada konsistensi implementasi maka apabila terjadi kehilangan dalam sebuah rumah, dapat dipastikan bahwa yang mengambil atau 
master mind untuk menggelapkan sesuatu dari rumah itu adalah penghuninya. Kunci rumah diserahkan kepada pimpinan atau wakil pimpinan, dan setiap mengambil sesuatu harus melapor dan minta ijin. Nah, pertanyaan selanjutnya: apakah anda yakin juga tidak terjadi apa-apa bila kunci itu dipegang oleh Wakil dan Pemimpin?

Kita tidak bisa menentukan bahwa integritas seorang pimpinan lebih hebat dibanding tukang sapu jalanan. Dalam konsep nilai pengendalian tak berlaku strata, usia, pendidikan dan jabatan.

\section{Pertanyaan untuk didiskusikan}

1. Bagaimana COSO ERM dapat membantu manajemen risiko dan praktisi untuk menavigasi risiko terkait lingkungan, sosial dan tatakelola?

2. Jelaskan bagaimana proses pengawasan ERM ditentukan dan dilaksanakan dengan jelas?

3. Apakah perbaikan proses berkelanjutan dikembangkan dan dipantau bersama?

4. Bagaimana menghubungkan proses ERM lingkungan, sosial dan tatakelola dengan manajemen risiko?

5. Jelaskan agara ERM tertanam dalam proses bisnis utama, pelaporan dan metrik?

\section{Soal Kasus}

PT ABC membawa misi sebagai cash cow bagi XYZ Corp dengan target setorancash sebesar Rp 7 triliun dalam 5 tahun. Dalam breakdown per tahun, pada tahun 20XX PT ABC harus menyetorkan Rp2,35 triliun. Target tersebut diproyeksikan dari berbagai aktivitas utama selama tahun 20XX sebagai berikut:

1. Manajemen aset saham $\mathrm{Rp} 2 \mathrm{~T}$,

2. Manajemen aset hak tagih Rp 0,5 T,

3. Manajemen aset properti $\mathrm{Rp} 0,3 \mathrm{~T}$ dan 
4. Manajemen dana Rp 0,3T.

5. Dana operasional yang dibutuhkan sebesar (Rp0,5 T)

Berdasarkan hasil perhitungan CFaR diketahui bahwa arus kas bersih sebesar Rp1,35 triliun. Bila dibandingkan dengan target setoran yang ditetapkan XYZ Corp sebesar Rp2,35 triliun, maka CFaR relatif adalah sekitar Rp1 triliun (Rp2,35T-Rp1,35T = Rp1 T).

Manajemen dapat merespons risiko dengan cara menghindarinya, mengurangi, mengalihkan, ataupun menerima.

Dalam hal manajemen memutuskan untuk menurunkan angka CfaR relatif, maka aktivitas pengendalian yang paling mungkin dalam konteks menghasilkan arus kas bersih yang lebih besar dapat dilakukan dalam tiga jalan. Jelaskan tiga jalan tersebut!

\section{Daftar Pustaka}

COSO. (2017b). Enterprise Risk Management Framework: Integrating with Strategy and Performance COSO 's Fundamental Principle. 1-32.

COSO. (2017a). Enterprise Risk Management Applying enterprise risk management to environmental, social and governancerelated risks

COSO Internal Control. (2013). Integrated Framework Principles. 2013

Moeller, R. R. (2016). Brink's Modern Internal Auditing Eighth Edition A Common Body of Knowledge Published by John Wiley \& Sons, Inc., Hoboken, New Jersey

Sarbanes. (2010a). Amendments to the Act. made by the DoddFrank Wall Street Reform and Consumer Protection Act (July 21, 2010). 


\section{BAB 6 \\ AREA AUDIT \\ MEMBENTUK AUDIT UNIVERSE DAN PROGRAM AUDIT}

\section{Capaian Pembelajaran}

1. Mahasiswa mampu memahami ruang lingkup dan tujuan audit internal universe

2. Mahasiswa mampu memahami kapabilitas dan tujuan audit internal

3. Mahasiswa mampu memahami keterbatasan waktu dan sumber daya dalam audit universe

4. Mahasiswa mampu menyusun program audit

\section{A. Pendahuluan}

Audit universe adalah kumpulan semua area yang tersedia untuk diaudit dalam suatu perusahaan. Untuk mendefinisikan audit universe, audit internal harus memahami jumlah entitas potensial yang dapat diaudit baik dalam hal unit bisnis atau area operasi dalam perusahaan dan jumlah unit atau aktivitas yang dapat diaudit di dalam dan di seluruh unit bisnis tersebut. Entitas yang dapat diaudit ini dapat didefinisikan dalam beberapa cara, seperti berdasarkan fungsi atau aktivitas, unit, divisi organisasi, proyek atau program (Auditor Internal, 2019). Beberapa contoh kegiatan yang dapat diaudit meliputi:

a. Kebijakan, prosedur, dan praktik yang terdapat di tingkat perusahaan maupun lokasi khusus.

b. Unit manufaktur, distribusi, atau rantai pasokan

C. Sistem informasi tentang infrastruktur dan tingkat aplikasi spesifik. 
d. Kontrak utama atau lini produk

e. Kegiatan media sosial yang dilakukan personil perusahaan

f. Fungsi seperti pembelian, akuntansi, keuangan, pemasaran.

Cara kedua dalam memandang entitas adalah dengan unit bisnis. Perusahaan dapat memiliki beberapa lini bisnis dengan operasi di seluruh dunia, dengan segudang otoritas dan struktur pelaporan. Agar auditor internal tidak tersesat dalam kompleksitas struktur perusahaan, maka harus melakukan inventaris yang terorganisir dari semua unit yang dapat diaudit. Definisi unit entitas yang dapat diaudit harus bergantung pada karakteristik organisasi tertentu dan apakah perusahaan itu diatur secara fungsional atau berpusat pada produk.

Audit potensial dapat mencakup semua operasi di divisi, unit anak perusahaan, fasilitas pabrik, atau unit utama di bawah pabrik. Pada dimensi lintas, audit internal dapat dijadwalkan di seluruh bagan organisasi yang mencakup semua operasi fungsional.

Tim audit internal juga harus menetapkan beberapa titik fokus audit untuk memastikan konsistensi dalam pelaksanaan semua audit internal yang potensial. Titik fokus ini, yang berfungsi sebagai garis besar umum untuk dokumen perencanaan audit dan program kerja audit yang membantu menghasilkan laporan status pengendalian.

\section{B. Menilai Kapabilitas dan Tujuan Audit Internal}

\section{Menilai Kapabilitas Auditor Internal}

Daftar terperinci dari unit-unit operasi yang menunjukkan semua bidang yang dapat ditinjau oleh audit internal bernilai kecil jika auditor internal tidak memiliki keterampilan dan sumber daya untuk meluncurkan audit di bidang-bidang tersebut. 
Kapabilitas digunakan untuk mengukur kemampuan dalam mengeksekusi suatu tanggung jawab. Banyak faktor yang membentuk tingkat kapabilitas seseorang, dimulai dari latar belakang pendidikan, experience, daya belajar dalam pengalaman (learning curve), mental attitude, profesionalisme serta daya pikir yang kreatif.

Karena internal audit adalah bagian dari suatu entitas yang harus merealisasikan tujuan nilai tambah bagi perusahaan, maka adalah sesuatu yang baik untuk memahami koordinat kapabitas yang dimiliki.

Internal Audit Capability Model (IACM),yang merupakan adaptasi dari Software Engineering Institute's Software Capability Maturity Model, dikembangkan oleh The Institute of Auditor internal s Research Foundation (IIARF) agar dapat digunakan secara global untuk menguatkan kapasitas dan meningkatkan efektivitas pengendalian internal ( Moeller, R. R. 2016).

Internal Audit Capability Model (IACM) adalah sebuah dokumen yang dihasilkan oleh IIARF dan bertujuan untuk memberikan gambaran tentang 5 level pertumbuhan kapabilitas sebuah organisasi internal audit dalam perusahaan (Auditor Internal, 2019). Dari fakta yang terlihat dalam praktiknya secara umum, kebanyakan organisasi internal audit cenderung tidak memiliki pattern yang jelas dan relatif sulit bagi mereka untuk menyimpulkan tingkat kapabilitas yang mereka gapai. Hal ini, menunjukkan bahwa belum ada keseriusan membuat road map yang mengacu kepada pengembangan resources serta metodologi yang cocok, konsisten berdasarkan nilai-nilai praktik terbaik.

Audit internal belajar dari dalam dan luar organisasi untuk pengembangan yang berkelaniutan

Lever 5

Optimizing 


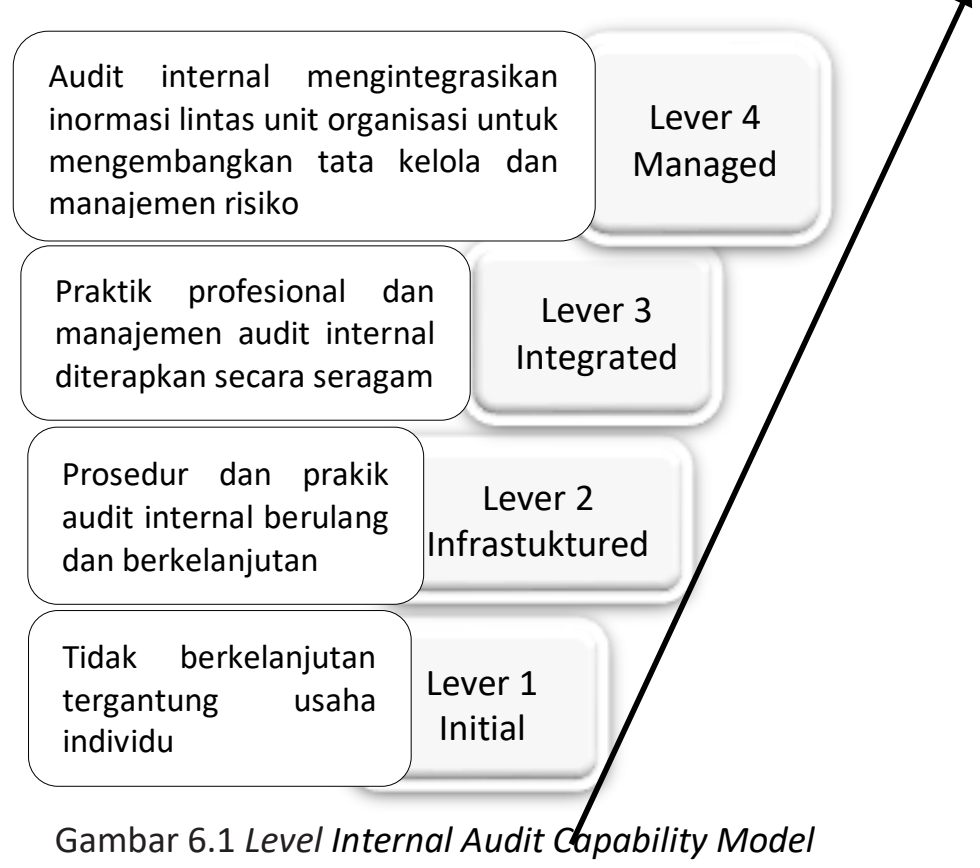

Sumber : (IIARF, 2009)

Aktivitas audit intern memiliki enam elemen utama:

a. Peran dan Layanan Audit Intern

b. Pengelolaan Sumber Daya Manusia

c. Praktik Profesional

d. Akuntabilitas dan Manajemen Kinerja

e. Budaya dan Hubungan Organisasi

f. Struktur Tata Kelola

IA-CM adalah suatu kerangka kerja untuk memperkuat atau meningkatkan audit intern melalui langkah evolusi kecil (IIARF, 2009). Langkah-langkah tersebut disusun menjadi lima level 
kapabilitas progresif. Level kapabilitas unit audit intern tersebut adalah: (1) initial; (2) infrastructure; (3) integrated; (4) managed; dan (5) optimizing.

Setiap level kapabilitas menggambarkan karakteristik dan kapabilitas unit audit internal pada level tersebut. Dengan meningkatnya ukuran atau kompleksitas organisasi atau risiko terkait dengan kegiatan, maka membutuhkan kapabilitas audit internal yang lebih baik lagi. Model ini mencoba untuk mencocokkan sifat dan kompleksitas organisasi dengan kapabilitas audit internal yang diperlukan untuk mendukungnya. Dengan kata lain, jika organisasi memerlukan tingkat kecanggihan yang lebih besar dalam praktik audit internal, kegiatan audit internal biasanya berada pada level kapabilitas yang lebih tinggi. Level kapabilitas audit internal seringkali terkait dengan struktur tata kelola organisasi di mana ia berada (IIARF, 2009).

2. Area-area proses kunci aktivitas audit intern tiap level dalam IACM berkaitan erat dengan keenam elemen tersebut. Jika diilustrasikan dalam bentuk matrik akan tersaji gambar 6.3 dibawah ini.

\section{Menilai Tujuan Audit Internal}

Auditor internal harus realistis dalam mengembangkan daftar audit universe. Auditor internal harus mengembangkan pemahaman yang tinggi tentang pengendalian risiko bisnis untuk masing-masing kandidat pada daftar audit universe dan menilai apakah ada risiko atau peluang untuk masing-masing kandidat audit universe. Berdasarkan daftar awal kandidat yang dapat diaudit, selanjutnya audit internal harus melangkah lebih jauh untuk mengembangkan daftar sumber daya auditnya. Meskipun mungkin masih ada beberapa 
ketidakpastian sifat beberapa unit bisnis dan masalah pengendalian internal, auditor internal harus menganalisis masing-masing kandidat potensial sebagai berikut:

a. Tetapkan tujuan pengendalian tingkat tinggi untuk setiap kandidat universe audit. Untuk menentukan mengapa unit ada dalam daftar audit serta sasaran pengendalian potensial.

b. Menilai risiko tingkat tinggi untuk calon audit universe. Auditor internal harus meninjau masing-masing kandidat audit universe dan memperkirakan risiko tingkat tinggi bagi perusahaan jika ada kegagalan pengendalian internal utama.

c. Mengkoordinasikan kegiatan audit internal dengan kepentingan audit dan tata kelola lainnya. Setiap pekerjaan audit yang direncanakan harus dikoordinasikan dengan pihak-pihak lain yang berkepentingan. Audit universe dan kegiatan perencanaan audit internal harus dikoordinasikan dengan permintaan audit eksternal.

d. Mengembangkan tujuan pengendalian tingkat tinggi untuk audit universe. Tujuan audit tingkat tinggi harus diidentifikasi untuk setiap item yang termasuk dalam audit universe. Ini harus berupa pernyataan sederhana tentang tujuan audit yang direncanakan untuk setiap item dalam audit universe untuk membantu memastikan bahwa strategi, tujuan, dan ruang lingkup untuk setiap audit mencakup tujuan pengendalian yang relevan. 


\begin{tabular}{|c|c|c|c|c|c|c|}
\hline & $\begin{array}{l}\text { Peran dan } \\
\text { layanan } \\
\text { audit } \\
\text { internal }\end{array}$ & $\begin{array}{l}\text { Pengeloaan } \\
\text { SDM }\end{array}$ & $\begin{array}{l}\text { Praktik } \\
\text { Profesional }\end{array}$ & $\begin{array}{l}\text { Akuntabilitas } \\
\text { dan Manajemen } \\
\text { Kinerja }\end{array}$ & $\begin{array}{l}\text { Budaya dan } \\
\text { Hubungan } \\
\text { Organisasi }\end{array}$ & Struktur Tata Kelola \\
\hline $\begin{array}{l}\text { Level } 5 \\
\text { Optimi } \\
\text { zing }\end{array}$ & $\begin{array}{l}\text { Audit } \\
\text { internal } \\
\text { diakui } \\
\text { sebagai agen } \\
\text { perubahan }\end{array}$ & $\begin{array}{l}\text { Keterlibatan } \\
\text { pimpinan } \\
\text { dalam } \\
\text { profesi } \\
\text { organisasi }\end{array}$ & $\begin{array}{l}\text { Praktik } \\
\text { profesional } \\
\text { dikembangan } \\
\text { secara } \\
\text { berkelanjutan }\end{array}$ & $\begin{array}{l}\text { Laporan } \\
\text { efektivitas audit } \\
\text { internal kepada } \\
\text { publik }\end{array}$ & $\begin{array}{l}\text { Hubungan } \\
\text { berjalanefektif } \\
\text { dan } \\
\text { berkelanjutan }\end{array}$ & $\begin{array}{lr}\text { Independensi, } \\
\text { kemampuan dan } \\
\text { kewenangan penuh } \\
\text { aktivitas } \\
\text { internal }\end{array}$ \\
\hline $\begin{array}{l}\text { Level } 4 \\
\text { Manag } \\
\text { ed }\end{array}$ & $\begin{array}{l}\text { Jaminan } \\
\text { menyeluruh } \\
\text { atas tata } \\
\text { kelola } \\
\text { manajemen } \\
\text { risiko dan } \\
\text { pengendalia } \\
\text { n organisasi }\end{array}$ & $\begin{array}{l}\text { Audit } \\
\text { internal } \\
\text { berkontribus } \\
\text { i terhadap } \\
\text { pengemban } \\
\text { gan } \\
\text { manajemen }\end{array}$ & $\begin{array}{l}\text { Strategi audit } \\
\text { mempengaruh } \\
\text { i manajemen } \\
\text { risiko } \\
\text { organisasi }\end{array}$ & \begin{tabular}{l}
\multicolumn{2}{l}{ Penggabungan } \\
ukuran kinerja \\
kualitatif dan \\
kuantitatif
\end{tabular} & $\begin{array}{l}\text { Pimpinan } \\
\text { audit internal } \\
\text { mampu } \\
\text { memberi } \\
\text { saran dan } \\
\text { mempengauhi } \\
\text { manajemen } \\
\text { puncak }\end{array}$ & $\begin{array}{l}\text { Pengawasan } \\
\text { independen terhadap } \\
\text { aktivitas audit } \\
\text { internal }\end{array}$ \\
\hline $\begin{array}{l}\text { Level } 3 \\
\text { Integra } \\
\text { ted }\end{array}$ & $\begin{array}{l}\text { Layanan } \\
\text { konsultansi }\end{array}$ & $\begin{array}{l}\text { Membangun } \\
\text { tim dan } \\
\text { kompetensi } \\
\text { nya }\end{array}$ & $\begin{array}{l}\text { Kerangka kerja } \\
\text { manajemen } \\
\text { kualitas }\end{array}$ & $\begin{array}{l}\text { Pengukuran } \\
\text { Kinerja }\end{array}$ & $\begin{array}{l}\text { Koordinasi } \\
\text { dengan pihak } \\
\text { lain yang } \\
\text { memberikan }\end{array}$ & $\begin{array}{l}\text { Pengawasan } \\
\text { manajemen terhadap } \\
\text { aktivitas audit } \\
\text { internal }\end{array}$ \\
\hline
\end{tabular}




\begin{tabular}{|l|l|l|l|l|l|l|}
\hline & & & & $\begin{array}{l}\text { saran } \\
\text { penjaminan }\end{array}$ & \\
\hline $\begin{array}{l}\text { Level 2 } \\
\text { Insfrast } \\
\text { ruktur }\end{array}$ & $\begin{array}{l}\text { Audit } \\
\text { Kepatuhan }\end{array}$ & $\begin{array}{l}\text { Pengemban } \\
\text { gan profesi } \\
\text { individu }\end{array}$ & $\begin{array}{l}\text { Kerangka kerja } \\
\text { profesional } \\
\text { dan prosesnya }\end{array}$ & $\begin{array}{l}\text { Anggaran } \\
\text { operasional } \\
\text { kegiatan audit } \\
\text { internal }\end{array}$ & $\begin{array}{l}\text { Pengelolaan } \\
\text { aktivitas audit } \\
\text { internal }\end{array}$ & $\begin{array}{l}\text { Akses } \\
\text { terhadap } \\
\text { manajemen dan SDM } \\
\text { inormasi }\end{array}$ \\
\hline $\begin{array}{l}\text { Level } 1 \\
\text { Initial }\end{array}$ & $\begin{array}{l}\text { Ad hoc dan tidak terstruktur, audit dan riviu terbatas pada dokumen dan transaksi untuk akuntansi dan } \\
\text { ketaatan, output tergantung dari keahlian orang pada posisi tertentu, tidak menerapkan praktik profesional } \\
\text { secara spesifik selain yang ditetap kan asosiasi profesional, pendanaan disetujui oelh manajemen sesuai } \\
\text { yang diperlukan, tidak adanya insfrastruktur, auditor diperlakukan sama seperti sebagian besar unit } \\
\text { organisasi, tidak ada kapabilitas yang dibangun, oleh karena itu tidak memiliki area proses kunci yang } \\
\text { spesifik. }\end{array}$ \\
\hline
\end{tabular}

\section{Gambar 6.2 Matrik Internal Audit Capability Model}

Sumber : (IIARF, 2009) 


\section{e. Mengembangkan kuesioner penilaian pengendalian}

awal untuk setiap audit. Dalam banyak situasi, pedoman audit harus diperbarui ketika proses berubah dan dievaluasi kembali untuk audit yang akan datang di setiap bidang. Dalam kasus lain, auditor internal harus mengembangkan beberapa langkah kuesioner tingkat tinggi untuk memulai ulasan audit universe.

Sebagai hasil dari pekerjaan tinjauan dan analisis, auditor internal harus mengembangkan jadwal audit universe awal yang akan menunjukkan area untuk tinjauan potensial. Daftar seperti itu mencakup bidang-bidang;

a. di mana terdapat kepentingan audit internal yang berulang,

b. di mana terdapat risiko kegagalan pengendalian internal yang lebih tinggi, dan

c. tujuan tinjauan tingkat tinggi lainnya.

Jenis pendekatan ini memberikan langkah awal auditor internal untuk memulai kegiatan perencanaan audit internal rutinnya.

\section{Keterbatasan Waktu dan Sumber Daya Dalam Audit Universe}

Dengan keterbatasan waktu dan sumberdaya auditor internal harus mengambil langka sebagai berikut;

a. Langkah pertama merencanakan kegiatan peninjauan potensial pada periode mendatang dan apa yang secara realistis dapat dimasukkan dalam ruang lingkup kegiatan audit. 
b. Langkah kedua adalah melihat daftar audit universe awal dan menentukan audit yang diperlukan secara tahunan atau bahkan setiap semester.

c. Langkah ketiga adalah melihat item-item yang tersisa dalam audit universe pendahuluan dan menentukan apakah waktu dan sumber daya tersedia untuk meninjau item-item yang tersisa.

Dalam beberapa situasi, audit memerlukan waktu penyelesaian audit yang banyak. Hal ini karena perubahan bisnis dan pasar, rentang waktu penyelesaian audit universe tidak boleh lebih dari lima tahun. Terkadang perlu memiliki lebih banyak sumber daya audit internal untuk hal-hal seperti;

a. keamanan jaringan $\mathrm{TI}$

b. perencanaan

c. pengujian kontinuitas

Semua data yang dikumpulkan dan asumsi perencanaan membantu auditor internal untuk membangun dan menerbitkan audit universe awal. Dokumen ini menunjukkan area di mana audit internal akan dilakukan pada periode mendatang, tujuan audit tingkat tinggi, dan risiko relatifnya. Jadwal audit internal juga harus mendokumentasikan, seperti;

a. audit yang akan dilakukan oleh jaminan kualitas,

b. ulasan lain yang belum dipertimbangkan karena berisiko rendah,

c. area audit telah dieliminasi karena kesulitan logistik, atau audit akan dilakukan oleh badan lain.

Auditor internal harus menyiapkan dokumen audit universe untuk periode tahun berjalan. Dokumen audit universe harus 
ditinjau dengan anggota manajemen senior dan kemudian disajikan kepada komite audit untuk disetujui.

\section{Menyusun Program Audit: Komponen Kunci Audit Universe}

Program audit adalah serangkaian langkah yang telah ditetapkan sebelumnya yang dilakukan oleh auditor internal (Fraud Examiner Manual, 2012). Program audit merupakan alat untuk merencanakan, mengarahkan, dan mengendalikan pekerjaan audit dan cetak biru untuk tindakan, menentukan langkah-langkah yang harus dilakukan untuk memenuhi tujuan audit. Program audit mewakili pemilihan tentang metode terbaik untuk menyelesaikan pekerjaan dan berfungsi sebagai dasar untuk merekam langkah-langkah kerja yang dilakukan.

Audit universe dan informasi pendukungnya menggambarkan tujuan audit internal tingkat tinggi di suatu area. Auditor internal harus menetapkan dan mendokumentasikan beberapa tujuan audit internal tingkat tinggi untuk setiap tinjauan yang direncanakan. Program audit juga merupakan panduan ketika menugaskan pekerjaan tersebut ke auditor tingkat staf. Program audit juga memberikan bantuan dan bimbingan kepada auditor internal untuk melakukan prosedur audit internal secara konsisten dan efektif dengan meminimalkan prosedur yang tidak perlu.

Departemen audit internal yang efektif harus memiliki serangkaian program audit standar yang disiapkan untuk kegiatan audit berulang seperti pengamatan inventaris fisik. Dalam situasi lain, auditor internal mungkin hanya perlu memodifikasi program standar untuk aspek unik dari audit tertentu. Dalam beberapa situasi, program audit standar tidak akan berlaku. Misalnya, auditor internal mungkin ingin meninjau 
pengendalian dalam entitas bisnis baru dengan beberapa karakteristik pengendalian yang unik, atau manajemen audit mungkin ingin mengambil pendekatan yang berbeda karena masalah yang dihadapi dengan ulasan sebelumnya yang serupa.

Berdasarkan tujuan audit yang direncanakan dan data yang dikumpulkan dalam survei pendahuluan dan survei lapangan, auditor harus menyiapkan program audit yang disesuaikan untuk memandu tinjauan. Untuk menyiapkan program revisian, auditor internal harus memiliki pemahaman tentang karakteristik dari entitas baru sehingga revisian program audit memadai.

\section{Format Program Audit dan Persiapannya}

Program audit adalah prosedur yang menggambarkan langkah-langkah dan tes yang harus dilakukan oleh auditor internal ketika melakukan pekerjaan lapangan. Program harus diselesaikan setelah survei pendahuluan dan survei lapangan dan sebelum memulai pekerjaan audit yang sebenarnya.

a. Program audit harus dibangun dengan beberapa kriteria dalam pikiran, yang paling penting adalah bahwa program audit harus mengidentifikasi aspek-aspek area untuk diperiksa lebih lanjut dan area sensitif yang memerlukan penekanan audit.

b. Program audit harus memberikan panduan kepada auditor internal yang kurang berpengalaman

Departemen audit internal sebaiknya memiliki perpustakaan program, yang dibentuk dari waktu ke waktu, untuk tugas-tugas seperti pengamatan inventaris fisik atau peninjauan aset tetap. Ketika merencanakan tinjauan di mana ada program yang sudah ada, manajemen audit hanya perlu 
menggunakan program yang sudah ada dengan pertimbangan direvisi seperlunya pada setiap perubahan kondisi yang telah ditemukan melalui survei awal atau survei lapangan atas persetujuan komite audit. .

Untuk banyak departemen audit internal, program audit yang tepat mungkin tidak tersedia untuk banyak bidang. Ini karena auditor internal biasanya dihadapkan dengan serangkaian bidang yang luas dan beragam untuk diaudit, tetapi tidak memiliki waktu atau sumber daya untuk meninjau setiap bidang secara berkala. Begitu juga program audit sebelumnya sering menjadi ketinggalan zaman karena sistem baru atau proses yang berubah.

Auditor yang bertanggung jawab untuk survei lapangan harus memperbarui program audit yang ada atau menyiapkan serangkaian langkah program audit yang direvisi untuk tinjauan yang baru direncanakan. Bergantung pada jenis audit, program biasanya mengikuti salah satu dari tiga format umum:

a. seperangkat prosedur audit umum,

b. prosedur audit dengan instruksi terperinci untuk auditor, dan

c. daftar periksa untuk tinjauan kepatuhan.

Gambar 6.3 adalah program audit untuk peninjauan pengendalian kas kecil di unit cabang kecil. Program audit ini terdiri dari prosedur audit umum untuk meninjau uang tunai di setiap unit organisasi multifasilitas. 


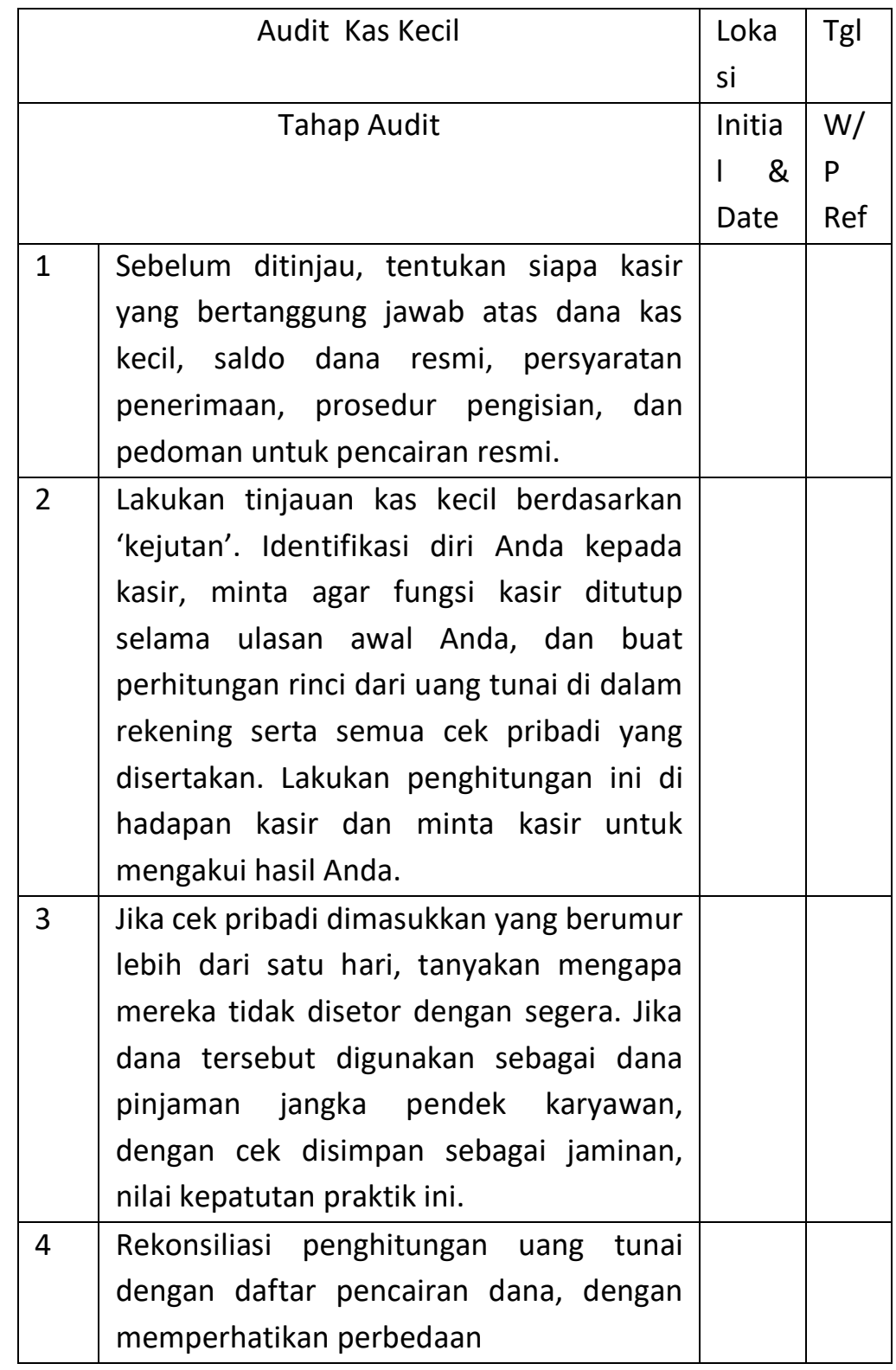




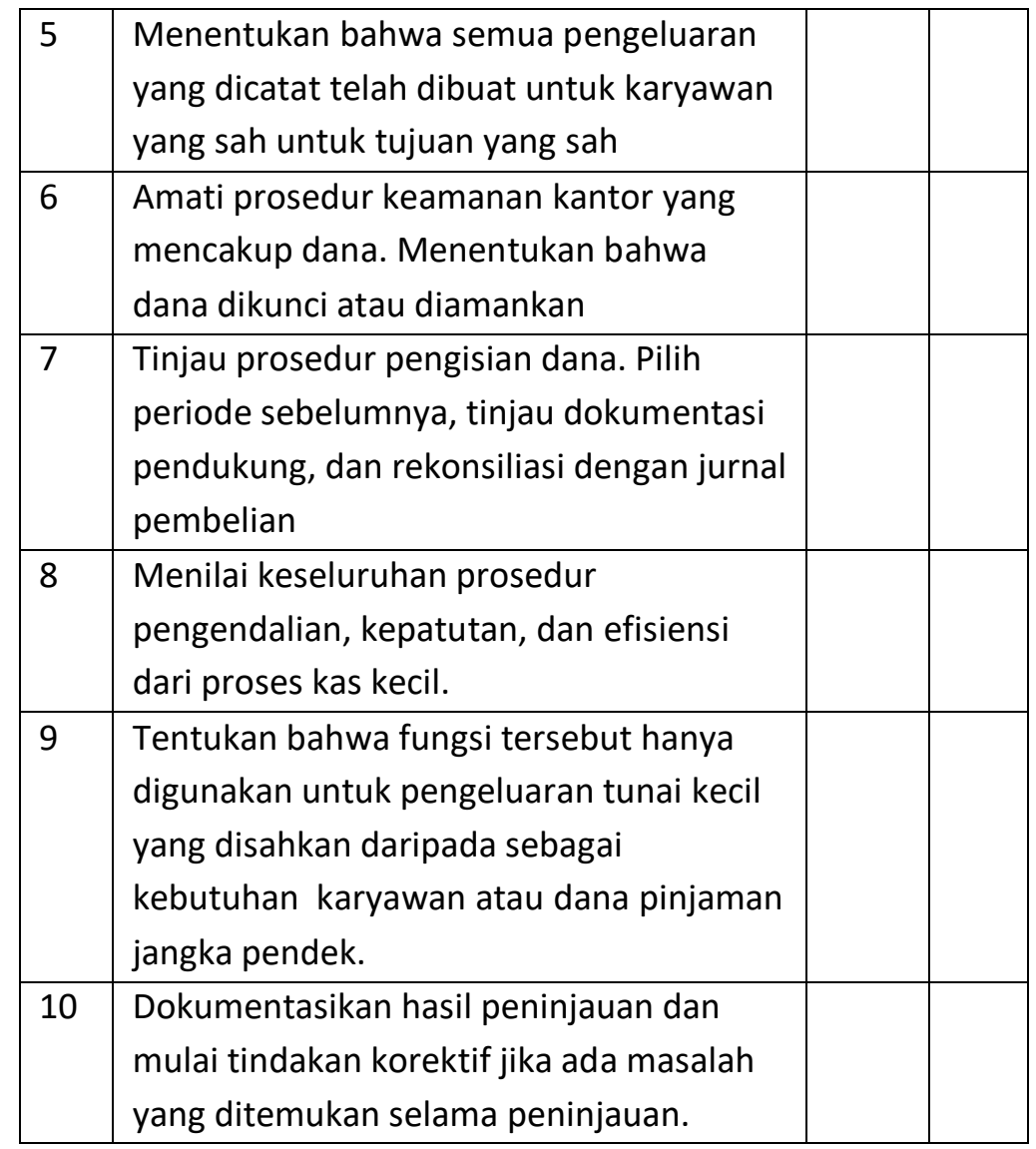

Gambar 6.3 Program Audit untuk Tinjauan kas kecil Sumber : (Audit Universe, 2018)

Perhatian utama adalah bahwa semua audit harus didukung oleh beberapa jenis program audit untuk mendokumentasikan langkah-langkah peninjauan yang dilakukan. Pendekatan ini memungkinkan manajemen audit untuk mengenali prosedur apa yang dilakukan atau tidak dilakukan oleh auditor dalam review. Program audit yang kuat 
dan konsisten adalah langkah penting untuk meningkatkan kualitas keseluruhan audit internal yang dilakukan.

\section{Jenis-Jenis Program Audit Untuk Memperoleh Bukti Audit}

Standar IIA menyatakan bahwa auditor internal harus memeriksa dan mengevaluasi informasi tentang semua hal yang berkaitan dengan tujuan audit yang direncanakan. Auditor internal harus mengumpulkan bukti audit untuk mendukung evaluasi. Sesuai standar audit internal bukti tersebut harus;

a. cukup,

b. kompeten,

c. relevan, dan

d. bermanfaat.

Program audit, yang dibangun dengan benar, mampu memandu auditor dalam proses pengumpulan bukti. Auditor internal akan menemukan banyak jenis bukti yang dapat berguna dalam mengembangkan kesimpulan audit. Auditor internal akan menghadapi berbagai tingkat bukti audit dan harus berusaha merancang prosedur audit untuk mencari dan mengandalkan bukti audit terbaik yang tersedia.

Keputusan auditor terkait pengumpulan bukti pendukung dapat dipisahkan menjadi empat golongan berikut (Hardiwinoto, 2014):

a. Prosedur audit mana yang akan digunakan.

b. Jumlah sampel yang akan dipilih untuk suatu prosedur tertentu.

c. Item mana yang akan dipilih dari populasi.

d. Kapan prosedur-prosedur itu akan dilaksanakan. 
Survei lapangan dan pengembangan dari program audit adalah kegiatan awal untuk melakukan audit yang sebenarnya. Biasanya yang melakukan survei lapangan dan pengembangan dilakukan oleh personil pengawas sebelum menugaskan auditor staf untuk peninjauan yang sebenarnya. Karena Auditor pengawas memiliki pengalaman untuk membuat penilaian cepat dari situasi lapangan dan untuk memperbaiki pendekatan audit keseluruhan. Setelah survei dan program audit akhir selesai dan telah ditinjau dan disetujui oleh manajemen audit internal, auditor internal melakukan audit aktual untuk memenuhi tujuan audit yang diinginkan. Pekerjaan persiapan dari survei akan memainkan peran penting dalam memastikan keberhasilan audit.

\begin{tabular}{|l|l|l|}
\hline \multicolumn{1}{|c|}{ Klasifikasi Bukti } & \multicolumn{1}{|c|}{ Kuat } & \multicolumn{1}{c|}{ Lemah } \\
\hline Teknik audit & Observasi/konfirmasi & Penyelidikan \\
\hline Asal bukti & bukti dokumen persh & Statistik \\
\hline $\begin{array}{l}\text { Hubungan dengan } \\
\text { audite }\end{array}$ & eksternal & Internal \\
\hline Bentuk bukti & tertulis & Oral \\
\hline Kecanggihan bukti & $\begin{array}{l}\text { Formal.terdokument } \\
\text { asi }\end{array}$ & Informal \\
\hline Lokasi bukti & $\begin{array}{l}\text { Dibuat dalam sistem } \\
\text { aktual }\end{array}$ & $\begin{array}{l}\text { Dari sistem } \\
\text { pendukung }\end{array}$ \\
\hline Sumber bukti & Pekerjaan auditor & Pihak kedua \\
\hline
\end{tabular}

Gambar 6.4 Klasifikasi "Bukti Terbaik" Audit Internal

Sumber : (Audit Universe, 2018)

Langkah-langkah audit aktual yang dilakukan akan tergantung pada karakteristik entitas yang diaudit. Audit yang berorientasi finansial atas fungsi kredit dan penagihan akan sangat berbeda dari tinjauan operasional departemen teknik desain. 
Audit keuangan dapat mencakup konfirmasi saldo saldo secara independen, sedangkan audit operasional mencakup wawancara ekstensif dengan manajemen dan dokumentasi pendukung untuk menilai pengendalian internal utama.

\section{E. Simpulan}

Agar auditor internal tidak tersesat dalam kompleksitas struktur perusahaan, maka harus melakukan inventaris yang terorganisir dari semua unit yang dapat diaudit. Definisi unit entitas yang dapat diaudit harus bergantung pada karakteristik organisasi tertentu dan apakah perusahaan itu diatur secara fungsional atau berpusat pada produk. Mendefinisikan entitas yang dapat diaudit dengan cara di mana ketika melakukan audit internal yang menghemat biaya.

Kapabilitas organisasi adalah merupakan kapabilitas kolektif dari orang-orang yang ada di dalam organisasi tersebut dalam merealisasikan tujuan yang disepakati. Karena internal audit adalah bagian dari suatu entitas yang harus merealisasikan tujuan nilai tambah bagi perusahaan, maka adalah sesuatu yang baik untuk memahami koordinat kapabitas yang dimiliki

Dalam beberapa situasi, audit memerlukan waktu penyelesaian audit yang banyak. Hal ini karena perubahan bisnis dan pasar, rentang waktu penyelesaian audit universe tidak boleh lebih dari lima tahun

\section{F. Contoh Kasus Area Audit}

Perusahaan produsen mobil yang mengoperasikan fasilitas manufaktur, pergudangan, dan perakitan serta terhubung ke jaringan dealer yang luas di seluruh dunia. Proses audit jarak jauh telah dilaksanakan secara berkala selama 10 tahun 
terakhir untuk memenuhi berbagai kebutuhan asurans. Proses audit jarak jauh digunakan untuk memantau kepatuhan terhadap peraturan serta kesesuaian terhadap kebijakan pada lokasi yang secara politik tidak stabil atau terdapat kekerasan regional dimana perjalanan berbahaya ataupun tidak mungkin dilakukan. Audit internal juga menggunakan proses audit jarak jauh untuk menangani volume yang tinggi, pengawasan atas operasi pihak ketiga yang sensitif terhadap waktu, seperti jaringan dealer dan kegiatan pergudangan global. Selain itu, teknik ini telah digunakan untuk memastikan pemahaman peran, tanggung jawab, dan persyaratan kerja terkait program keselamatan yang kritikal serta untuk mengkonfirmasi implementasi tindakan korektif atas risiko tinggi dan isu yang bersifat sistemik. Dengan munculnya COVID-19 serta adanya dampak ekonomi dan kendala perjalanan, lini pertahanan kedua telah mengadopsi strategi untuk melakukan validasi yang tidak mungkin dilakukan.

\section{Solusi}

a. Perencanaan audit jarak jauh

Perencanaan dan penentuan lingkup merupakan hal yang sangat penting dalam setiap audit. Namun pelaksanaan hal tersebut akan menjadi lebih sulit pada saat pihak yang berkepentingan berada di lokasi yang saling berjauhan, sementara rapat perencanaan dengan pemangku kepentingan adalah hal yang sangat penting. Pertemuan tersebut mencakup diskusi tentang ruang lingkup dan jadwal, auditor juga harus memberikan waktu yang memadai untuk menjelaskan pendekatan proses audit jarak jauh kepada para peserta rapat. Termasuk 
memberikan penjelasan mengenai hal-hal yang perlu diantisipasi terkait kesamaan dan perbedaan antara audit tatap muka langsung yang sudah umum bagi para pemangku kepentingan dengan proses audit jarak jauh.

Sebagai contoh informasi yang harus dibahas diantaranya adalah bagaimana dan kapan informasi akan dibagikan, teknologi apa yang akan digunakan (mulai dari kamera hingga drone sampai dengan dukungan kehadiran dari jarak jauh/telepresence), otorisasi apa yang perlu diperoleh sebelumnya untuk dapat melakukan pengambilan video maupun fotografi, serta area rahasia atau terbatas apa yang perlu dipertimbangkan atau dihindari.

Penting juga untuk membahas sejak awal keterbatasan proses audit jarak jauh serta menjelaskan bahwa pelaksanaan kerja lapangan mungkin masih diperlukan pada masa yang akan datang berdasarkan temuan audit jarak jauh, atau pada saat hambatan terhadap kunjungan fisik telah disingkirkan (misalnya, larangan bepergian dicabut).

Berdasarkan kebutuhan atas keterangan serta penjelasan tambahan, pengalaman yang ada menunjukkan bahwa auditor internal harus mengalokasikan waktu dua kali lebih banyak guna melakukan rapat perencanaan audit jarak jauh, bila dibandingkan dengan yang diperlukan dalam audit tradisional. Penggunaan video teleconference serta PowerPoint atau panduan visual lainnya, juga bermanfaat untuk pertemuan ini. 
b. Kajian dokumen jarak jauh

Mungkin diperlukan lebih banyak waktu bagi pihak terkait untuk menyiapkan dan mengunggah dokumen ke platform berbagi file (SharePoint, drive bersama, dll.) bila dibandingkan dengan menyediakan akses ke tempat arsip atau binder pada lokasi kerja. Metode dokumentasi (rekaman dalam kertas kerja, system penyimpanan basis data, dll.) yang ada dapat membutuhkan tambahan waktu untuk mengubah catatan menjadi format yang dapat dikaji (seperti PDF) dan mengunggah file tersebut.

Pertimbangan yang cermat harus diberikan untuk mengembangkan strategi yang efektif dalam melakukan pengkajian data dari jarak jauh. Misalnya, penggunaan sampel mungkin merupakan pilihan terbaik, tergantung pada jumlah rekaman catatan yang akan diperiksa, Terlepas apakah auditor memeriksa semua atau sebagian dari data yang tersedia, strategi yang akan digunakan harus didiskusikan terlebih dahulu dengan auditee untuk memastikan kebenaran informasi yang diberikan guna mendukung strategi pengambilan sampel.

Tidak seperti pengkajian rekaman catatan di lokasi, pengkajian dokumen dari jarak jauh biasanya tidak memungkinkan untuk memberikan pertanyaan langsung pada saat yang sama. Pada saat mengkaji dokumen dari jarak jauh, auditor harus mencatat dan menuliskan pertanyaan yang akan ditanyakan selama wawancara jarak jauh. Namun, salah satu cara yang memungkinkan pertanyaan dilakukan bersamaan dengan pengkajian dokumen jarak jauh adalah dengan mengatur video 
teleconference antara auditor dengan orang yang ditugaskan untuk melaksanakan pekerjaan yang sedang dikaji. Hal ini memungkinkan dokumen untuk dibagikan dan dikaji, sekaligus untuk menyampaikan pertanyaan dan mendapatkan jawaban secara langsung pada saat yang sama.

c. Pemeriksaan fisik jarak jauh

Pemeriksaan fisik lapangan dari jarak jauh mungkin merupakan aspek yang paling menantang dari pelaksanaan audit jarak jauh. Perusahaan-perusahaan yang berkontribusi pada tulisan ini telah mencoba berbagai solusi teknologi untuk memenuhi kebutuhan pemeriksaan fisik lapangan secara memadai.

Salah satu pendekatannya adalah dengan memanfaatkan teknologi komunikasi langsung dua arah, termasuk penggunaan livestreaming dan teknologi twoway smart glasses (kacamata pintar dua arah).

Alternatif untuk komunikasi langsung dua arah adalah dengan video dan foto digital yang diambil menggunakan telepon seluler perusahaan. Keuntungan dari pendekatan ini adalah perangkat tersebut tersedia dan kompatibel dengan sebagian besar solusi penyimpanan komputer perusahaan (misalnya, SharePoint). Selain itu, kekuatan sinyal pada titik pengambilan tidak berdampak negatif terhadap kualitas video dan foto pada perangkat tersebut.

Foto dan video ditinjau oleh manajer audit dan dikompilasi menjadi sebuah album, yang kemudian ditinjau oleh masing-masing auditor. Auditor membuat catatan dan 
menyiapkan pertanyaan untuk ditanyakan selama wawancara jarak jauh

d. Wawancara jarak jauh

Wawancara jarak jauh dilakukan dengan cara yang hampir sama dengan wawancara langsung serta dapat dilakukan melalui penjadwalan panggilan video terhadap personil-personil inti dengan menggunakan sejumlah teknologi yang tersedia (misalnya, Microsoft Teams, Skype, dan Zoom). Rencanakan wawancara antara 30 hingga 90 menit dengan penanggungjawab pekerjaan. Wawancara pendek sekitar 15 menit dapat dilakukan dengan personil yang ditunjuk dan memiliki tanggung jawab dalam implementasi, sementara wawancara singkat (sekitar 10 menit) dapat dilakukan dengan personil lainnya yang bertanggung jawab dalam mendukung fokus audit. Hal ini dapat membantu auditor internal untuk mendapatkan pengetahuan tentang budaya yang umum berlaku. Panggilan video lebih disukai daripada panggilan suara saja karena isyarat non-verbal merupakan bagian penting dari komunikasi dan seringkali tidak nampak tanpa video.

Mempersiapkan wawancara jarak jauh membutuhkan waktu tambahan bagi auditor. Setiap auditor harus siap dengan daftar pertanyaan dan hal-hal terkait informasi tambahan apa yang dibutuhkan, berdasarkan informasi yang diprolehl dari kajian dokumen. Ketika lebih dari satu auditor berpartisipasi dalam wawancara, kepedulian harus dilakukan supaya tidak terjadi tumpang tindih pembicaraan dengan personil yang diwawancarai maupun dengan auditor lainnya. 
e. Pertemuan penutup jarak jauh

Pertemuan penutupan untuk audit jarak jauh sama dengan pertemuan penutupan untuk audit secara langsung. Disarankan untuk menjadwalkan pertemuan penutupan satu hingga dua hari setelah wawancara jarak jauh. Hal ini memungkinkan anggota tim audit untuk meninjau kembali catatan dan temuannya, serta mengadakan rapat tim audit untuk menyusun rancangan awal hasil audit.

Pertemuan penutupan audit merupakan kesempatan untuk mempresentasikan rancangan awal hasil audit kepada para peserta pemangku kepentingan, menyelesaikan pertanyaan atau permasalahan, serta melakukan pembahasan lebih lanjut untuk finalisasi hasil audit dan pengembangan berkelanjutan.

\section{Pertanyaan untuk didiskusikan}

1. Jelaskan pengertian audit universe!

2. Jelaskan pengertian area audit!

3. Jelaskan tahap-tahap penentuan area audit!

4. Jelaskan program audit kas kecil dan bukti yang mendukung program tersebut.

\section{Soal Kasus Program Audit}

Anda sedang mengaudit kas kecil pada suatu perusahaan Program audit ini terdiri dari prosedur audit umum untuk meninjau uang tunai di setiap unit organisasi multifasilitas

Buat program audit untuk kas kecil!

\section{Daftar Pustaka}

Auditor Internal. (2019). Audit universeAuditors. (October), 1-6.

Audit Universe. (2018). Copy of Audit Universe and Risk 
Assessment Tool.

Fraud Examiner Manual. (2012). Pengumpulan dan evaluasi bukti. Hardiwinoto. (2014). Bukti Audit. Dapat diunduh pada http://hardiwinoto.com/bukti-audit/

IIARF. (2009). Internal Audit Capability Model (IA-CM): For the Public sector, 2009.

Moeller, R. R. (2016). Brink's Modern Internal Auditing Eighth Edition A Common Body of Knowledge Published by John Wiley \& Sons, Inc., Hoboken, New Jersey. 


\section{BAB 7 \\ MEMBANGUN FUNGSI AUDIT INTERNAL}

\section{Capaian pembelajaran}

1. Mahasiswa mampu menyusun piagam audit internal

2. Mahasiswa mampu memahami fungsi audit internal

3. Mahasiswa mampu memahami tanggung jawab manajer audit internal.

4. Mahasiswa mampu memahami peran audit internal masa kini

\section{A. Pendahuluan}

Tidak ada satu cara optimal untuk membangun fungsi audit internal dalam suatu perusahaan saat ini. Mungkin ada banyak perbedaan dalam jenis bisnis, rentang geografis, dan struktur organisasi, dengan kebutuhan audit internal yang berbeda untuk masing-masing. Namun, setiap perusahaan harus mengikuti standar dan harus beroperasi di bawah Kerangka Kerja Praktik Profesional Internalasional (IPPF) dan harus mendapat dukungan dan pengakuan dari manajemen senior perusahaan (The Institute of Auditor internal s, 2016). Kebutuhan akan fungsi audit internal berasal dari persyaratan perusahaan seperti Securities and Exchange Commission Act Sarbanes - Oxley (SOx), atau persyaratan hukum dari lembaga pemerintah.

Jika entitas yang baru diluncurkan belum memiliki fungsi audit internal, manajemen senior harus mengambil langkahlangkah untuk memulai membangun fungsi audit internal. Seorang manajer senior, yang ditunjuk sebagai kepala audit, 
harus membangun fungsi audit internal baru yang dihadapkan pada berbagai opsi, tergantung pada;

a. proses bisnis keseluruhan perusahaan,

b. struktur organisasi dan

c. sumberdaya yang disiaapkan

d. berbagai risiko pengendalian yang dihadapinya.

e. budaya perusahaan secara keseluruhan.

Persyaratan utama untuk organisasi yang efektif adalah pemimpin yang kuat; pemimpin dalam fungsi audit internal adalah kepala eksekutif audit yang memahami kebutuhan organisasi secara keseluruhan dan risiko pengendalian potensial serta kontribusi yang dapat dihasilkan oleh auditor internal. Perusahaan besar saat ini memiliki unit binis yang tersebar di seluruh dunia. Departemen audit internal yang efektif harus dikelola dengan cara filosofi melayani manajemen senior dan komite audit dengan ;

a. memberikan layanan audit terbaik,

b. paling hemat biaya untuk seluruh organisasi.

Untuk membangun fungsi audit internal yang efektif langkah pertama adalah memiliki piagam audit internal yang disetujui oleh komite audit dan manajemen senior.

\section{B. Piagam Audit Internal}

Piagam audit internal adalah dokumen formal, yang disetujui oleh komite audit, yang menggambarkan;
a. misi,
b. independensi,
c. objektivitas,
d. ruang lingkup,
e. tanggung jawab, 
f. wewenang,

g. akuntabilitas, dan

h. standar fungsi audit internal.

Auditor internal memiliki kebebasan untuk melihat berbagai catatan dan untuk mengajukan pertanyaan di semua tingkatan. Auditor internal memiliki banyak tanggung jawab dalam suatu perusahaan, dan beberapa jenis otorisasi diperlukan. Dalam struktur perusahaan, fungsi audit internal melapor kepada komite audit dewan, selanjutnya komite audit mengotorisasi hak dan tanggung jawab auditor internal melalui piagam audit internal harus menegaskan audit internal:

a. Kemandirian dan obyektivitas

b. Lingkup tanggung jawab

c. Otoritas dan akuntabilitas

Piagam audit internal adalah dokumen otorisasi untuk fungsi auditor internal perusahaan yang digunakan sebagai dasar untuk melaksanakan audit internal. Piagam audit internal telah memberikan akses auditor internal ke catatan perusahaan. Lebih penting lagi, piagam ini memberikan otorisasi tingkat tinggi untuk fungsi audit internal perusahaan.

Tidak ada format tetap untuk isi piagam, tetapi standar audit internal IIA, merujuk perlunya piagam audit internal. Piagam audit internal dengan jelas menguraikan otoritas auditor internal serta tanggung jawab seperti mengembangkan rencana audit berbasis risiko dan mengeluarkan laporan audit yang tepat waktu.

\section{Fungsi Audit Internal}

Setiap fungsi audit internal perlu memiliki seseorang yang bertanggung jawab untuk audit internal antara lain auditor kepala 
serta beberapa staf pendukung dan administrasi. Walaupun ada banyak variasi dalam uraian posisi dan jabatan, ada beberapa model uraian posisi auditor internal untuk berbagai tingkat dan jenis auditor internal dalam suatu perusahaan. (Audit Universe, 2018).

\section{Peran Kepala Audit}

Standar IIA mendukung jabatan kepala eksekutif audit dengan tanggung jawab utama untuk seluruh fungsi audit internal. Tidak peduli apakah kepala eksekutif audit bekerja di perusahaan besar, perusahaan swasta, atau organisasi nirlaba yang relatif kecil, kepala eksekutif audit adalah orang yang ditunjuk untuk memimpin dan mengarahkan fungsi audit internal perusahaan. Tanggung jawab kepala eksekutif audit juga tercermin dalam piagam audit internal:

a. Operasi perusahaan dan masalah risiko. Selain mengelola fungsi audit internal, kepala eksekutif audit harus memiliki pengetahuan mengenai semua aspek operasi perusahaan, baik keuangan, operasional, atau masalah pasar.

b. Administrasi sumber daya manusia dan audit internal. Kepala eksekutif audit bertanggung jawab atas staf audit internal dan harus membangun organisasi yang efektif dan merekrut serta memimpin tim audit internal yang efektif.

c. Hubungan dengan komite dan manajemen audit. Kepala eksekutif audit adalah juru bicara audit internal untuk komite audit dan semua tingkatan manajemen perusahaan.

d. Masalah tata kelola perusahaan, akuntansi, kepatuhan, dan peraturan. Apakah berurusan dengan SOx, akuntansi, masalah keuangan, atau masalah regulasi lainnya yang 
mempengaruhi perusahaan, auditor kepala harus memiliki setidaknya pemahaman dan pengetahuan umum.

e. Pembangunan dan administrasi tim audit internal. Terlepas dari ukuran timnya, kepala eksekutif audit bertanggung jawab untuk membangun fungsi audit internal yang efektif.

f. Teknologi. Kepala eksekutif audit harus memiliki pemahaman umum tentang bagaimana teknologi digunakan dalam perusahaan serta bagaimana teknologi itu dapat diterapkan untuk mempromosikan layanan audit internal.

g. Perencanaan audit berbasis risiko. Kepala eksekutif audit harus memahami proses penilaian risiko sebagaimana diterapkan pada operasi perusahaan, dan juga harus dapat memikirkan operasi dalam hal proses-proses utama ini.

h. Masalah media sosial. Melalui penggunaan produk seperti Facebook, Twitter, atau lainnya, alat dan proses media sosial memperkenalkan perubahan besar dalam perusahaan saat ini; auditor kepala harus memahami perubahan ini dan bagaimana pengaruhnya terhadap perusahaan.

i. Keterampilan menegosiasikan dan manajemen hubungan. Kepala eksekutif audit sering diminta untuk merundingkan resolusi yang tepat untuk masalah-masalah ini sebagai bagian dari membangun tim audit internal yang efektif.

j. Kepastian audit internal dan peran konsultasi. Kepala eksekutif audit harus selalu menekankan kepada tim audit internal dan manajemen peran terpisah antara 
menyediakan layanan jaminan audit internal dan menyediakan layanan konsultasi.

\section{k. Standar Internalasional untuk Praktik Profesional Audit}

Internal. Kepala eksekutif audit harus menjadi ahli dalam standar IIA, harus memahami konsep IPPF, dan harus membantu menerapkannya pada semua aspek kegiatan audit internal.

Kepala eksekutif audit memiliki pekerjaan penting baik dalam memimpin departemen audit internal yang efektif dan dalam memberikan layanan audit internal kepada perusahaan.

\section{Tanggung Jawab Manajer Audit Internal}

Bergantung pada ukuran perusahaan secara keseluruhan, fungsi audit internal dapat memiliki beberapa tingkatan penyelia atau manajer audit internal untuk memonitor dan mengelola fungsi audit internal secara dekat. Manajer adalah sumber daya yang menciptakan fungsi audit internal yang efektif melalui perencanaan yang ketat, pemantauan, dan pengawasan staf audit lapangan yang melakukan audit internal. Sementara kepala eksekutif audit biasanya harus menjadi generalis audit internal dengan pengetahuan yang baik tentang masalah pengendalian internal perusahaan dan praktik audit internal, manajer audit internal dan penyelia umumnya menjadi spesialis di bidang-bidang seperti masalah audit internal keuangan atau TI.

Manajer audit internal diharapkan memiliki Akuntan Publik Bersertifikat (CPA) dan Auditor Internal Bersertifikat (CIA) yang memungkinkan manajer dapat berkomunikasi lebih baik dan memahami masalah keuangan dan akuntansi dengan manajemen perusahaan dan staf audit internal. Manajer juga 
harus memiliki keterampilan pengendalian internal TI yang baik.

Dalam sebuah perusahaan fungsi sumber daya manusia dapat memberlakukan persyaratan tersebut. Struktur organisasi fungsi audit internal harus disusun sedemikian rupa sehingga semua anggota staf audit internal dapat mengenali persyaratan untuk berpindah dari satu tingkat ke tingkat berikutnya.

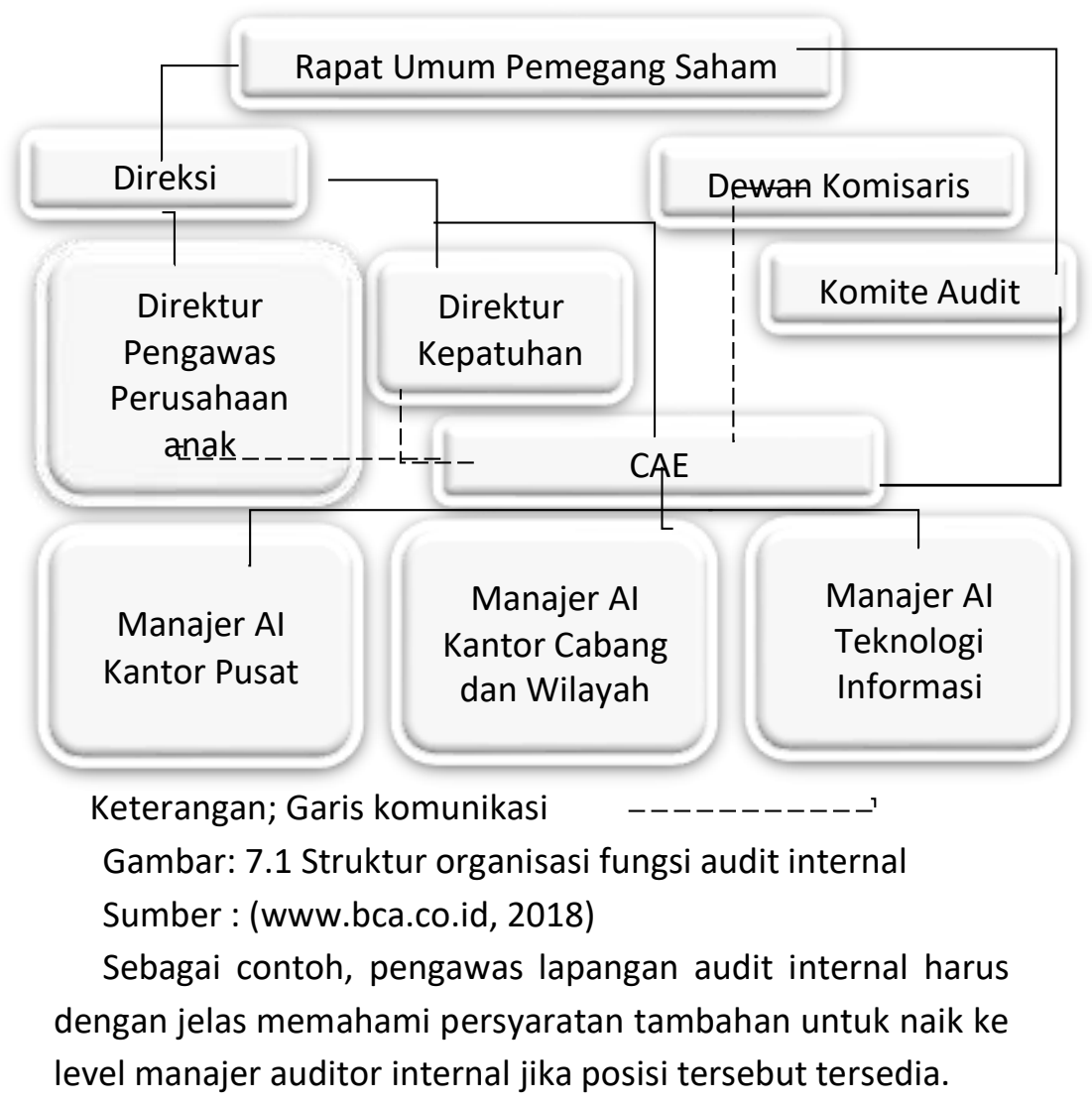


Divisi Audit Internal dipimpin oleh Kepala Divisi dan bertanggung jawab kepada Presiden Direktur dan Komite Audit, serta dapat berkomunikasi langsung dengan Dewan Komisaris, Direktur Kepatuhan dan Direktur yang membawahi Perusahaan Anak. Auditor kepala dibantu oleh beberapa manajer audit internal untuk beberapa bidang, seperti manajer auditor internal kantor pusat, manajer auditor internal kantor cabang dan wilayah, manajer auditor internal teknologi informasi.

\section{Tanggung Jawab Staf Audit Internal.}

Di banyak perusahaan, fungsi audit internal adalah tempat masuk yang sangat baik bagi anggota staf baru, yang baru saja lulus dari perguruan tinggi, non-spesialis. Karena tidak ada program pelatihan audit internal yang spesifik, maka perusahaan harus mencari calon auditor internal dengan gelar di bidang keuangan, akuntansi, ekonomi, atau sistem informasi.

Tingkat staf, seorang auditor internal pemula harus seseorang yang dapat dengan cepat meninjau proses bisnis yang sering kompleks, menilai kelemahan potensial, dan kemudian mengomunikasikan masalah tersebut kepada manajemen audit internal dan manajemen perusahaan secara keseluruhan.

Posisi auditor tingkat staf dapat menjadi slot tingkat entri ke dalam fungsi auditor internal. Tentu saja, jika seorang calon baru memiliki gelar bidang internal auditing, telah lulus setidaknya sebagian dari ujian CPA atau CIA, atau melakukan beberapa audit internal di perusahaan lain, calon harus dibawa pada tingkat yang lebih senior. 


\section{Spesialis Audit Sistem Informasi}

Banyak staf auditor internal dapat berhasil dalam suatu perusahaan dengan hanya pengetahuan umum dan dapat belajar lebih banyak melalui pelatihan, untuk menjadi auditor internal spesialis TI memerlukan pelatihan dan keterampilan tambahan. Kebanyakan fungsi audit internal memerlukan setidaknya satu spesialis pada staf audit internal dengan keterampilan pengendalian internal terkait-TI yang kuat yang mencakup bidang-bidang seperti;

a. keamanan sistem,

b. pengendalian internal aplikasi, dan

c. manajemen operasi sistem komputer.

Jenis persyaratan keterampilan auditor internal ini melampaui posisi entry level di mana calon auditor entry-level yang memiliki gelar sarjana dalam ilmu komputer memiliki pemahaman dasar tentang spreadsheet.

Persyaratan keterampilan untuk spesialis audit sistem informasi dalam grup audit internal sangat bergantung pada kematangan teknis fungsi TI perusahaan. Suatu perusahaan yang memiliki aplikasinya seperangkat perencanaan sumber daya perusahaan dari aplikasi terkait yang dikaitkan dengan database yang kompleks akan memerlukan serangkaian keahlian sistem informasi audit yang berbeda dari pada perusahaan di mana sebagian besar sumber daya IT-nya berbasis web.

\section{Peran Audit Internal Masa Kini}

Auditor internal sampai dekade lalu masih menikmati posisi nyaman sebagai pemeriksa yang menemukan berbagai temuan di unit kerja yang diperiksa (Sarbanes, 2002). Auditor internal selalu 
berkeliling ke semua unit kerja untuk mencari tahu apakah unit kerja tersebut tidak melanggar semua ketentuan yang berlaku dan instruksi yang diberikan serta bekerja secara efisien dan efektif. Pada akhir pemeriksaan, auditor menyodorkan temuan, hasil penilaian, dan simpulan.

Bagaimana dengan cara berpikir dan mental auditor internal saat ini, apakah tidak berubah dibandingkan yang lampau? Untuk auditor internal yang bekerja di organisasi komersial, cara berpikir dan mental sebagai pemeriksa dan pengawas yang tugas utamanya hanya memeriksa, mendapatkan finding, dan menyusun laporan, adalah sangat berbahaya. Terlebih organisasi komersial tersebut berada di industri yang persaingannya sangat kompetitif baik persaingan yang datang dari sesama perusahaan lokal maupun dari serangan impor luar negeri dan perusahaan asing.

Risiko utama yang dihadapi adalah risiko perubahan. Teknologi, selera konsumen, lingkungan sosial politik yang berubah sangat cepat adalah risiko yang harus dimaknai oleh auditor internal agar mentransformasi organisasi kerja, cara atau metode kerja, dan kompetensi sehingga dapat memenuhi ekspektasi pengguna jasa audit internal.

Cita-cita besar yang dicanangkan The Institute of Auditor internal $s$ (IIA) untuk profesi auditor internal masa kini adalah auditor internal yang dapat menjadi mitra strategis dan advisor yang dapat dipercaya bagi manajemen, dewan komisaris dan seluruh unit kerja di organisasi. Hal ini bisa tercapai bila auditor internal memiliki visi dan motivasi yang sama dengan cita-cita tersebut dan pengguna utama jasa auditor internal, yaitu manajemen dan dewan komisaris merasa butuh dan menganggap 
auditor internal dapat membantu tugas mereka menjalankan dan mengawasi organisasi.

Auditor internal harus dapat memberikan solusi mendasar yang sesuai dengan masalah yang dihadapi organisasi. Solusi itu semestinya memberikan dampak, segar, cerdas atau bernilai tambah sehingga membantu manajemen dan dewan komisaris mengarahkan organisasi mencapai tujuannya. Auditor internal tidak zamannya lagi hanya sekedar melihat atau memotret masalah yang historis, melihat masalah hanya secara parsial dan tidak substansial karena hal itu bukan solusi yang dibutuhkan manajemen dan dewan komisaris.

Agar dapat menjadi mitra strategis, syarat utama kompetensi auditor internal adalah mampu menyelesaikan masalah, berpikir analitis, dan relationship. Kegagalan auditor internal menampilkan output yang memiliki nilai tambah akan membuat para pengguna jasa memandang auditor internal sebagai fungsi yang tidak ada gunanya, tidak relevan lagi dengan kondisi bisnis, hanya menjadi beban operasional.

\section{Pendekatan yang Pre-emptif, Proaktif, Bukan Reaktif}

Paradigma bahwa audit internal adalah aktivitas yang post ante atau bekerja setelah adanya transaksi, kontrak, membuat hasil keluaran audit internal sering disebut terlambat. Post ante cocok jika pendekatannya adalah compliance dan control centric yang hanya menceritakan penyimpangan, efisiensi, kerugian, kelemahan pengendalian. Namun jika pendekatannya adalah dari sisi risk centric dan risk assurance maka auditor internal dapat memberikan nilai tambah pada keluarannya. 
Oleh karena itu, kombinasi compliance dan control centric dengan risk centric merupakan alternatif solusi bagi auditor internal. Ini berarti agar auditor internal mampu melakukan pendekatan dan paradigma risk-centric, auditor internal wajib selangkah di depan melalui pengembangan pengetahuan terkini secara mandiri atau diwajibkan oleh tempat bekerjanya.

2. Berupaya Melakukan Analisis Akar Permasalahan (Root Causes)

Setiap auditor internal yang berpengalaman tahu bahwa temuan yang diperolehnya sudah disadari oleh klien, namun klien tidak tahu atau enggan mencari akar masalah yang substansial atau enggan menyelesaikan masalah. Auditor internal yang profesional semestinya tidak mengupas temuan sekedar dari kulit luar atau simtom saja, melainkan menggali informasi lebih dalam dari berbagai dimensi tentang masalah yang ditemukan untuk ditelusuri akar masalahnya.

Bisa jadi akar masalah menyangkut model bisnis, kebijakan manajemen, budaya organisasi, kualitas kompetensi pegawai. Inilah yang sebenarnya dibutuhkan oleh manajemen dan dewan komisaris. Elite organisasi harus berbesar hati bilamana akar masalah menyentuh hal yang hakiki yang terkait dengan kebijakan, sikap, perilaku, koordinasi, ego, dan gaya kepemimpinan.

\section{Mencari SDM Auditor yang Terbaik}

Apabila manajemen dan dewan komisaris ingin menjadikan auditor internal sebagai mitra strategis maka seharusnya mengubah unit audit internal setara dengan unit bisnis yang menghasilkan penghasilan dan uang bagi organisasi 
atau unit enabler lain yang menunjang organisasi memperoleh dan mempertahankan bisnis.

Karena kualitas auditor internal sangat ditentukan pada brainware maka tidak mungkin dapat mencetak auditor internal dengan cepat. Butuh waktu, butuh anggaran, butuh kesempatan, dan butuh karier. Bekali auditor internal dengan pengetahuan dan ketrampilan audit internal, pengetahuan, dan ketrampilan lain yang menunjang dan selalu update dengan dinamika bisnis. Misal, saat ini sedang mengemuka IFRS 9, digital world \& reinvention, intelligent process automation, cybersecurity dll.

\section{Mengedukasi Dewan Komisaris atau Komite Audit dan Manajemen tentang Definisi Audit Internal}

Banyak ketidakpahaman tentang apa itu audit internal dan apa yang dihasilkan oleh audit internal sehingga masih banyak terjadi auditor internal diperlakukan multiguna dan adhoc. Demikian juga tidaklah banyak diketahui metode dasar audit internal adalah hubungan antara tujuan organisasi yang biasanya merupakan target bisnis atau indikator kinerja lainnya dengan risiko-risiko melekat dan pengendalian internal serta tata kelola.

Pemahaman tentang apa yang dimaksud dengan pengendalian internal yang memadai dan efektif oleh pemilik risiko yang dilakukan assurance dan apa dampaknya terhadap tujuan organisasi jika pengendalian internal dan tata kelola tidak memadai dan tidak efektif perlu disampaikan oleh auditor internal saat membahas hasil observasi oleh auditor. 


\section{Mendorong Perubahan dan Perbaikan yang Kontinyu di Unit Kerja yang Diaudit}

Pada dasarnya inti dari temuan atau hasil observasi audit internal adalah menghendaki perubahan dan perbaikan. Keberhasilan audit internal terletak bukan pada banyaknya temuan, terlebih jika hanya temuan administratif atau temuan dokumenter, namun terletak pada perubahan dan perbaikan.

Zona kenyamanan, keengganan bertransformasi, keengganan koordinasi, hilang motivasi atau perilaku organisasi lain yang disfungsional merupakan objek perubahan dan perbaikan. Aspek inilah yang menjadi tantangan auditor internal untuk mengembangkan temuan, akar masalah, dan solusi. Aspek ini juga yang menjadi tantangan pemimpin audit internal meyakinkan elite organisasi bahwa temuan ini sangat penting dan perlu perubahan bertahap, sistematis, komprehensif secara luas (organization wide).

Apakah auditor internal adalah agen perubahan ataukah penjaga status quo?" Kengganan untuk berubah merupakan risiko terbesar organisasi dan organisasi yang demikian akan menuju kematiannya sebab pada kondisi yang fluktuatif, berubah dengan sangat cepat bahkan chaos, organisasi yang dapat bertahan hidup adalah yang inovatif, kreatif, dinamis, fleksibel, resilient, intelligent, dan smart.

Adakah auditor internal yang siap melakukan assessment terhadap perilaku organisasi, faktor manusia, daya dukung teknologi dan infrastruktur untuk meyakini membantu kesuksesan organisasi terhadap visi, tujuan, dan strateginya, serta risiko yang melekat? 
Merubah citra audit internal yang hanya fungsi support atau penyedia jasa menjadi advisor yang dapat dipercaya (trusted advisor) dan kontibutor corporate leader. Untuk dapat menjadi trusted advisor dan kontibutor corporate leader, auditor internal tidak boleh sunyi senyap tertinggal (apalagi terbelakang), tidak nampak di pentas organisasi, dan statis memelihara status quo dan zona nyamannya.

Sebaliknya auditor internal wajib memiliki kemampuan dan menawarkan hindsight (tinjauan yang empiris atas historis yang sudah terjadi), insight (kecemerlangan wawasan dan konsep yang dalam), dan foresight (tinjauan ke masa depan). Cara pandang auditor internal adalah masa lalu (past), saat ini (present), dan yang akan datang (future) akan membuat auditor internal sebagai profil yang dicari pendapat dan pemikirannya.

Dengan cara ini, stigma auditor internal sebagai stopper atau berkutat pada compliance-centric akan berubah menjadi valued experts di nature of work-nya yaitu tata kelola, manajemen risiko, dan pengendalian.

Menghadapi dan memanfaatkan teknologi setiap auditor internal wajib diberi pengetahuan dasar tentang teknologi informasi (risiko, tata kelola dan pengendalian internal, serta best practices), wajib diberi ketrampilan audit dengan menggunakan teknologi informasi (data analytics, continuous auditing, perangkat lunak audit) sebab pada era sekarang cara kerja audit konvensional semata menjadi tidak bernilai dan tidak efisien.

Apabila organisasi menghadapi teknologi lain selain teknologi informasi, misal teknologi produksi, pemeliharaan 
dll, maka auditor internal harus mengetahui hal yang mendasar tentang teknologi tersebut.

\section{E. Simpulan}

Unit Audit Internal dibentuk berdasarkan ketentuan sebagai berikut:

a. Undang-Undang No. 40/2007 tentang Perseroan Terbatas;

b. Undang-Undang No. 8/1995 tentang Pasar Modal;

c. Peraturan Otoritas Jasa Keuangan No. 56/POJK.04/2015 tanggal 29 Desember 2015 tentang Pembentukan dan Pedoman untuk Penyusunan Piagam Unit Internal Audit (“POJK No. 56/2015");

Unit Audit Internal memiliki Piagam yang menetapkan tujuan, organisasi, tanggung jawab, wewenang dan ruang lingkup Unit Audit Internal.

Unit Audit Internal memberikan keyakinan yang independen dan obyektif atas efektivitas dan integritas proses manajemen risiko, pengendalian dan tata kelola,dan memberikan konsultasi sesuai kebutuhan departemen dan unit Perseroan yang dirancang untuk memperkuat kegiatan operasional mereka. Dengan demikian, Unit Audit Internal menambah nilai ada kegiatan operasi Perseroan dan mendukung pencapaian tujuan.

Unit Audit Internal bertanggung jawab untuk:

a. Mengidentifikasi dan mengevaluasi paparan risiko yang penting, dan berkontribusi untuk memperkuat manajemen risiko dan sistem pengendalian internal;

b. Membantu Perseroan dalam mempertahankan pengendalian internal yang efektif dengan mengevaluasi 
efektivitas dan efisiensi dan mendorong perbaikan secara terusm enerus untuk mencapai hal-hal sebagai berikut:

i. Keandalan dan integritas informasi keuangan dan operasional Perseroan terjamin;

ii. Efektifitas operasional Perseroan sehingga memberikan hasil yang efektif;

iii. Aset Perseroan terjaga dengan baik; dan - Seluruh tindakan dan keputusan Perseroan sesuai dengan peraturan perundang-undangan yang relevan.

iv. Aktivitas audit internal harus berkontribusi terhadap tata kelola Perseroan

Unit Audit Internal juga bertanggung jawab untuk membuat rencana audit tahunan melalui konsultasi dengan Presiden Direktur dan Komite Audit, dan berkoordinasi dengan Dewan Komisaris, Direksi, dan Komite Audit dalam mengeksekusi setiap rencana audit.

\section{F. Contoh Kasus Peran Audit Internal Masa Kini}

Tidak ada pembahasan strategis tanpa adanya pembahasan tentang risiko. "Risiko" adalah separuh dari pertukaran antara "risk dan reward." Secara sederhana, tidak ada arah atau inisiatif strategis yang dapat dilaksanakan sebuah organisasi tanpa adanya risiko.

Sebuah organisasi harusnya tidak menetapkan sebuah strategi tanpa sebelumnya memiliki pemahaman yang utuh tentang risiko-risikonya. Di sinilah seorang auditor internal bisa berperan strategis secara efektif. Kepala auditor nternal harus menyampaikan kepada board bukan hanya tentang risiko-risiko, tapi bagaimana risiko-risiko tersebut dapat atau akan dikendalikan dan apakah proses pengendalian tersebut 
merupakan bagian dari kerangka pengendalian yang sudah ada atau membutuhkan sumber daya yang berbeda.

\section{Solusi}

Auditor internal harus dapat memberikan solusi mendasar yang sesuai dengan masalah yang dihadapi organisasi. Solusi itu semestinya memberikan dampak, segar cerdas atau bernilai tambah sehingga membantu manajemen dan dewan komisaris mengarahkan organisasi mencapai tujuannya. Auditor internal tidak zamannya lagi hanya sekedar melihat atau memotret masalah yang historis, melihat masalah hanya secara parsial dan tidak substansial karena hal itu bukan solusi yang dibutuhkan manajemen dan dewan komisaris.

\section{Pertanyaan untuk didiskusikan}

1. Jelaskan struktur organisasi audit internal dalam sebuah perusahaan multinasional!

2. Jelaskan pemahaman saudara tentang piagam audit internal!

3. Jelaskantugas dan tanggungjawab audit internal

\section{Soal kasus}

Perusahaan ketiga yang berkontribusi dalam tulisan ini, terpaksa melakukan transisi audit tradisional ke proses audit jarak jauh disebabkan adanya pembatasan perjalanan terkait COVID19. Situasi tersebut melibatkan tenggat waktu yang ketat yang diatur berdasarkan hukum yang ada. Para auditor berada di Paris, Denver, dan Houston. Sedangkan tempat kerja tersebut berada di California, serta karyawannya bekerja dari rumah.

Seorang karyawan mengambil file yang dibutuhkan dan membagikannya di Skype. Auditor menjadwalkan dan melakukan wawancara di rumah untuk para auditee di Jerman, Boston, dan empat lokasi di Amerika Serikat - Washington DC; Virginia; 
Michigan; dan Los Angeles. Yang mengejutkan semua orang, audit dapat memenuhi tenggat waktu dan mencapai tujuannya.

Sebagai staf audit internal bagaimana menjadwal dan melakukan wawancara serta pemeriksaan dokumen yang dilakukan oleh auditor tersebut.

\section{Daftar Pustaka}

Audit Universe. (2018). Copy of Audit Universe and Risk Assessment Tool.

Moeller, R. R. (2016). Brink's Modern Internal Auditing Eighth Edition A Common Body of Knowledge Published by John Wiley \& Sons, Inc., Hoboken, New Jersey.

The Institute of Auditor internal s. (2016). Standar Internasional Untuk Praktek Profesional Auditing Internal.

www.bca.co.id. (2018). www.bca.co.id > tentang-bca > old-tatakelola-perusahaan > media 


\section{BAB 8}

\section{MENGUJI, MENILAI, DAN MENGEVALUASI BUKTI AUDIT}

\section{Capaian Pembelajaran}

1. Mahasiswa mampu memahami jenis bukti audit

2. Mahasiswa mampu memahami teknik penilaian dan evaluasi bukti audit

3. Mahasiswa mampu mengembangkan rencana sampling statistik.

4. Mahasiswa mampu memahami pendekatan sampling audit.

5. Mahasiswa mampu memahami prosedur pengambilan sampel atribut.

6. Mahasiswa mampu melakukan tes pengambilan sampel atribut.

7. Mahasiswa mampu memilih sampel untuk melakukan prosedur audit.

8. Mahasiswa mampu memahami hasil uji sampling atribut.

9. Mahasiswa mampu memahami keunggulan dan kelemahan sampel atribut.

10. Mahasiswa mampu memahami sampling unit moneter.

11. Mahasiswa mampu membuat sampling audit yang efisien dan efektif

\section{A. Pendahuluan}

Akan banyak tantangan dan bahkan rintangan yang hadapi jika pola fikir tidak berlandaskan nilai. Begitu juga ketika mengambil bukti audit dalam era big data banyak ragam cara yang bisa dilakukan agar mendapatkan bukti yang bernilai. Internal auditor harus memahami bahwa definisi bukti sangat filosofis 
sehingga tidaklah cukup dengan memerankan roles melalui persfektif rutinitas, ceklis atau hanya compliance based.

Pemahaman pada proses bisnis, risiko, control dan governance adalah sesuatu yang harus dimiliki oleh internal auditor, sehingga tahu apa yang menjadi bagiannya dalam implementasi mendapatkan bukti yang bernilai. Bukti harus dinilai berdasarkan tatakelola, kemungkinan terjadinya risiko, dampak risiko serta pengendalian. Tentu cara penilaian bukti sangat tergantung tujuan audit.

Big data dapat mendukung auditor dalam mengumpulkan bukti audit ketika bukti audit yang diperoleh melalui tradisional audit tidak mencukupi atau bukti audit berkualitas rendah. Munculnya bisnis e-commerce merupakan pendorong untuk menerapkan teknik big-data based auditing. Meningkatnya perusahaan yang tadinya bersifat "brick-and-mortar sales" berubah menjadi "internet sales" mendorong auditor untuk mampu beradaptasi dengan cepat terkait dengan pemahaman proses bisnis client nya yang berbeda-beda untuk tiap client.

Satu hal yang harus diingat adalah, bukti audit yang dihasilkan oleh big data umumnya memberikan petunjuk keterkaitan, bukan sebab-akibat.

\section{B. Bukti Audit}

Auditor internal harus mengumpulkan bukti ketika melaksanakan audit. Bukti audit adalah segala informasi yang digunakan oleh auditor dalam rangka menentukan informasi audite sesuai dengan kriteria yang ditetapkan.

Pertama, bukti yang dikumpulkan oleh auditor internal harus relevan karena merupakan salah satu bagian dari rangkaian buktibukti (chain of evidence) yang menggambarkan suatu proses 
kejadian atau jika bukti tersebut secara tidak langsung menunjukkan kenyataan dilakukan atau tidak dilakukannya suatu perbuatan.

Kedua, bukti yang dikumpulkan oleh auditor internal harus kompeten yang dibuat oleh pihak yang berkompeten dan bukti diperoleh dengan cara yang sah. Ketiga, bukti yang dikumpulkan oleh auditor internal harus cukup berkaitan dengan jumlah bukti yang dapat dijadikan dasar untuk menarik suatu simpulan audit.

Bukti audit yang relevan, kompeten dan cukup digunakan oleh auditor internal membuat penilaian tentang masalah audit atau memenuhi tujuan audit. Pengumpulan bukti jauh lebih sulit ketika audit internal dihadapkan pada populasi yang besar untuk diperiksa. Selanjutnya, auditor harus memeriksa set sampel terbatas bukti atau laporan untuk mengembangkan kesimpulan audit atas seluruh set bukti audit atau populasi data.

Secara khusus, mengingat sistem TI saat ini, auditor internal memerlukan beberapa cara untuk meninjau big data yang terkomputerisasi (Fraud Examiner Manual, 2012). Ini adalah tantangan utama bagi auditor internal. Auditor internal memerlukan pendekatan yang konsisten untuk mengambil sampel sebagian item dari populasi big data dan kemudian untuk menarik kesimpulan audit berdasarkan sampel terbatas tersebut. Tantangan pengambilan sampel audit internal adalah untuk mengekstraksi sampel item yang mewakili seluruh populasi. Kesimpulan audit hanya dapat dianggap benar jika sampel yang diambil mewakili seluruh populasi. Teknik pengambilan sampel audit dapat membantu auditor internal menentukan ukuran sampel yang sesuai dan mengembangkan pendapat untuk jenis tugas audit ini. 


\section{Teknik Penilaian dan Evaluasi Bukti Audit}

\section{Penilaian Bukti Audit}

Ketika merencanakan audit mencakup pemeriksaan sejumlah besar bukti audit dapat berupa transaksi atau dokumen lain, auditor internal dihadapkan pada dua pilihan yaitu sampling statistik dan non-statistik (Fraud Examiner Manual, 2012). Sampling statistik adalah metode berbasis matematis untuk memilih item yang representatif yang mencerminkan karakteristik seluruh populasi. Dengan menggunakan hasil tes audit pada item yang diambil secara statistik, auditor internal kemudian dapat menyatakan pendapat tentang seluruh kelompok.

Sampling nonstatistik, juga disebut judgemental sampling, tidak didukung oleh teori matematika. Namun demikian, pengambilan sampel nonstatistik atau penilaian sering kali merupakan alat audit yang berguna. Mengapa menggunakan sampling audit? Karena audit sampling dapat menjadi alat yang sangat efektif untuk auditor internal. Dengan pengambilan sampel, auditor internal dapat menarik kesimpulan berdasarkan tingkat keyakinan misalnya $98 \%$ (http://yukbelajaraudit.blogspot.com/, 2014).

Sampling audit adalah alat yang ampuh, dan dengan beberapa studi dan praktik, auditor internal dapat dengan mudah dan efektif mulai menggunakan pengambilan sampel audit. Setiap kali auditor internal menarik kesimpulan berdasarkan sampel audit dapat menjadikan audit yang lebih baik dan lebih efisien. Alasan-alasan berikut ini mendorong penggunaan sampling statistik: 
a. Kesimpulan dapat diambil mengenai seluruh populasi data. Jika metode sampling statistik digunakan, informasi dapat diproyeksikan secara akurat pada seluruh populasi tanpa melakukan pemeriksaan $100 \%$ pada populasi.

b. Hasil sampel objektif dan dapat dipertahankan. Kesalahan pengendalian intern sering terjadi secara acak atas jumlah item yang mengalami kesalahan, dan setiap kondisi kesalahan harus memiliki kesempatan yang sama untuk pemilihan dalam sampel audit.

c. Pengurangan sampel mungkin diperlukan melalui penggunaan sampling audit. Auditor internal tidak perlu meningkatkan ukuran sampel secara langsung dalam proporsi untuk meningkatkan ukuran populasi yang akan dijadikan sampel.

d. Pengambilan sampel statistik bahkan dapat memberikan akurasi yang lebih besar daripada tes $100 \%$.

e. Cakupan audit di beberapa lokasi seringkali lebih nyaman. Audit dapat dilakukan di beberapa lokasi dengan sampel kecil diambil di lokasi masing-masing untuk menyelesaikan rencana pengambilan sampel secara keseluruhan.

f. Prosedur pengambilan sampel bisa mudah diterapkan. Auditor internal dapat menggunakan tabel yang diterbitkan dalam manual pengambilan sampel atau sistem komputer yang kompleks untuk mengembangkan rencana pengambilan sampel dan pemilihan sampel. 
Dengan pengambilan sampel nonstatistik, judgmental, informasi hanya diperoleh tentang item-item yang diperiksa. Dengan sampling statistik, terlepas dari jumlah item yang diperiksa, informasi positif dapat diperoleh tentang semua item dalam populasi dalam tingkat kepercayaan statistik.

\section{Sampel Penilaian.}

Sampling penilaian nonstatistik seringkali juga dapat menjadi prosedur audit internal yang sangat tepat dalam banyak situasi. Pendekatan ini auditor internal menggunakan penilaian terbaiknya untuk merancang dan memilih sampel. Sampel penilaian dilakukan dengan cara memilih sampel item yang representatif dalam populasi data atau transaksi untuk tinjauan audit. Metode pemilihan sampel penilaian antara lain:

a. Pemilihan persentase tetap. Pemeriksaan persentase tetap seperti $10 \%$ dari item dalam populasi audit.

b. Pemilihan atribut yang ditunjuk. Pilihan semua atau sebagian item yang aktif selama periode waktu tertentu, seperti satu bulan dalam audit yang mencakup transaksi satu tahun.

c. Pemilihan nilai yang besar. Pilihan untuk pemeriksaan audit atas item-item tersebut dengan saldo moneter signifikan.

d. Pemilihan area yang ditentukan. Pemeriksaan hanya untuk item yang tersedia, seperti yang disimpan dalam laci file tertentu. Item sampel tersebut dapat dipilih karena terlihat "menarik."

e. Pemilihan atribut lain yang dipilih. Item inventaris yang tidak aktif atau usang, auditor dapat memilih untuk meninjau hanya item-item yang tampak berdebu 
Data yang diperoleh dari sampel penilaian, hasilnya dapat menyesatkan atau tidak akurat. Dengan pendekatan sampel penilaian auditor internal dapat menilai keakuratan biaya keuangan untuk $10 \%$ dari biaya terbesar dari beberapa akun. Meskipun tidak ada masalah signifikan yang ditemukan untuk sampel 10\%, auditor tidak akan mengetahui adanya permasalahan pengendalian signifikan atas sisa akun yang mewakili 90\%. Ketika merencanakan tinjauan berdasarkan sampel penilaian, auditor internal harus membuat tiga keputusan pengambilan sampel penilaian.

a. Pertama, auditor internal harus mengembangkan metode pemilihan, dan memutuskan jenis barang apa yang akan diperiksa. Auditor internal dapat dikritik jika masalah muncul kemudian yang tidak termasuk dalam pemilihan sampel.

b. Kedua ukuran sampel harus masuk akal dibandingkan dengan seluruh populasi. Sampel yang terlalu kecil tidak akan mewakili keseluruhan populasi, sementara sampel yang terlalu besar mungkin memakan waktu ekstra atau mahal untuk dievaluasi.

c. Keputusan ketiga adalah bagaimana menafsirkan dan melaporkan hasil audit dari sampel penilaian terbatas.

Auditor internal dapat memilih item sampel sebanyak atau sesedikit mungkin yang tampak sesuai dalam penilaian profesional auditor internal. Seringkali, auditor internal yang baik dapat "mencium" masalah potensial dengan melihat area dan memilih serangkaian item yang mewakili masalah potensial. 
Meskipun ada beberapa opsi pada pendekatan di sini, auditor internal yang sukses seringkali lebih baik menggunakan beberapa bentuk sampling statistik untuk pemilihan item audit.

\section{Mengembangkan Rencana Sampling Statistik}

Sebagai langkah pertama untuk pengambilan sampel, auditor internal harus mengembangkan rencana pengambilan sampel yang memungkinkan setiap item dalam suatu populasi memiliki probabilitas pemilihan yang sama (Jusup, 2001). Pengambilan sampel statistik memungkinkan auditor internal untuk menarik sampel representatif dan membuat kesimpulan audit atas seluruh populasi data. Namun, seorang auditor internal harus mengerti sifat data yang akan ditinjau ketika mengembangkan strategi pemilihan sampel statistik atau rencana audit, termasuk

a. Populasi yang dijadikan sampel harus ditentukan dengan jelas. Populasi adalah jumlah total unit dari mana sampel dapat diambil, termasuk ruang lingkup atau sifat barang yang akan ditinjau

b. Populasi harus dibagi atau distratifikasi ke dalam kelompok jika ada variasi besar di antara item populasi

c. Setiap item dalam suatu populasi harus memiliki peluang yang sama untuk dipilih dalam sampel.

d. Seharusnya tidak ada bias dalam memilih sampel dari populasi.

Rencana pengambilan sampel yang digunakan harus secara jelas didokumentasikan dan didiskusikan dengan manajemen, Pengembangan rencana pengambilan sampel adalah langkah 
penting untuk setiap sampel audit. Ada empat metode umum untuk memilih sampel audit

\section{(http://yukbelajaraudit.blogspot.com/, 2014):}
a. nomor acak,
b. interval,
c. bertingkat,
d. pemilihan kluster.

Auditor internal modern harus memiliki pemahaman umum tentang teknik yang paling tepat untuk situasi audit tertentu (Jusup, 2001).

\section{Pemilihan Sampel Audit Nomor Acak .}

Pemilihan sampel berdasarkan angka acak mengasumsikan bahwa sebagian besar populasi mengikuti distribusi kurva standar. Banyak populasi tidak mengikuti distribusi normal, sehingga menimbulkan pertanyaan tentang kelayakan menggunakan sampling audit. Seringkali akun terdiri dari populasi kecil tetapi dengan saldo besar dan populasi besar memiliki saldo kecil. Mereka tidak mengikuti distribusi standar meskipun dasar dari banyak metode sampling statistik yang dibahas mengasumsikan bahwa distribusi tersebut dalam bentuk distribusi normal. Namun, metode yang bagus untuk memastikan hasil yang lebih akurat ketika sampel diambil dari populasi yang memiliki kecenderungan buruk adalah dengan meningkatkan ukuran sampel. Teori statistik mengatakan bahwa ketika ukuran sampel semakin besar, bentuk distribusi sampling menjadi lebih dekat dengan distribusi normal.

\section{Pemilihan Sampel Audit Interval}

Metode ini membutuhkan pemilihan item individual berdasarkan interval seragam dari item dalam total populasi. 
Teknik ini sangat berguna untuk pengambilan sampel unit moneter, di mana auditor internal akan mengembangkan sampel dengan memilih setiap item ke-n dalam populasi, seperti dari daftar inventaris. Diperlukan adanya populasi yang cukup homogen, dalam hal jenis barang, dan tidak ada bias dalam pengaturan populasi yang akan menghasilkan sampel yang tidak representatif secara statistik. Seleksi interval harus terkait dengan ukuran sampel dan total populasi. Ukuran sampel yang direncanakan dibagi ke dalam ukuran populasi kemudian menetapkan interval.

Misalnya, populasi 5.000 dan sampel 200 yang dibutuhkan akan menghasilkan persyaratan interval 5.000/200 atau setiap item ke-25. Auditor internal kemudian akan memeriksa setiap item ke-25 dalam seri populasi dengan titik awal pada kelompok interval pertama yang ditetapkan berdasarkan angka acak.

Jika populasi aktual ternyata lebih besar dari yang diperkirakan, solusi praktis adalah meningkatkan sampel dengan memperluas pemilihan interval dengan dasar yang sama. Jika populasi aktual kurang dari yang diperkirakan, maka perlu melengkapi sampel melalui pemilihan interval baru berdasarkan jumlah item kecil terkait dengan ukuran total populasi. Masalah ini bisa dihindari dengan selalu memiliki margin keselamatan melalui estimasi sampel yang lebih besar dari yang dibutuhkan.

Pilihan interval di mana setiap item ke-n yang dipilih merupakan cara termudah untuk mengambil sampel dari suatu populasi; Namun, sifat dasar dari metode tersebut kemungkinan bias dalam pemilihan sampel. Misalnya, dalam 
sampel transaksi harian dengan pilihan interval setiap 30 hari, jika angka acak awal menunjuk ke awal bulan, kesalahan kepatuhan yang terjadi di akhir bulan bisa tidak terdeteksi. Auditor internal dapat memilih hari ke 5 bulan 1, dilanjutkan hari ke 6 bulan 2 dan seterusnya. Berdasarkan teknik tersebut, item dari hari ke 15 hingga sekitar hari ke 30 tidak akan pernah dipilih. Karena bias ini, auditor internal harus berhati-hati sebelum menggunakan teknik ini.

\section{Sampel Audit Stratifikasi}

Pendekatan stratifikasi suatu populasi dibagi menjadi dua atau lebih subkelompok atau strata, dengan masing-masing subkelompok ditangani secara terpisah sebagai populasi yang terpisah. Seleksi bertingkat adalah perpanjangan dari teknik pemilihan acak atau interval, dapat diterapkan pada strata populasi yang lebih kecil. Dalam beberapa kasus, salah satu strata dapat diperiksa $100 \%$ sementara yang lain dikenakan seleksi acak. Justifikasi untuk stratifikasi mungkin karena satu strata memiliki karakteristik yang sangat berbeda, dan auditor internal mungkin ingin mengevaluasi subkelompok tersebut secara lebih individual dan tepat.

Melalui pengurangan variabilitas, stratifikasi dapat mengurangi deviasi standar dan membantu mengurangi ukuran sampel. Dengan menggunakan stratifikasi, auditor internal dapat membagi populasi ini menjadi dua strata: item lebih dari Rp 100 juta dan item di bawah Rp 100 juta. Strata yang kurang dari Rp 100 juta akan menjadi subjek pemilihan acak, sedangkan strata yang lebih besar dari Rp 100 juta akan diseleksi $100 \%$. Populasi paling umum yang membutuhkan 
stratifikasi adalah seperti persediaan, piutang dagang, atau faktur.

\section{Seleksi Sampel Audit Klaster}

Pendekatan pengambilan sampel klaster, sampel dibuat dengan memilih secara sistematis subkelompok atau kelompok dari total populasi. Pemilihan kluster berguna ketika item ditempatkan dalam rak atau dalam laci dan secara fisik lebih mudah untuk memilih subkelompok berdasarkan area fisik rak. Alasannya adalah bahwa barang-barang pada bagianbagian tertentu dari area rak yang ditunjuk pada dasarnya memiliki sifat yang serupa dan sampel yang dipilih akan representatif. Namun, variabilitas dalam sampel individu sering kurang dari variabilitas di antara sampel. Oleh karena itu, untuk mengimbangi variabilitas yang lebih rendah, adalah menggunakan sampel yang lebih besar.

\section{E. Pendekatan Sampling Audit}

Auditor internal dapat mengambil beberapa pendekatan pengambilan sampel audit tergantung pada tujuan audit, apakah itu didasarkan pada tes kepatuhan, pengendalian laporan keuangan, atau pada kondisi khusus apa pun. Tiga pendekatan yang paling umum di sini (Jusup, 2001) adalah :
a. sampel atribut
b. sampel variabel (termasuk unit moneter sampling),
c. sampel penemuan.

\section{Sampel Atribut}

Pengambilan sampel atribut digunakan untuk mengukur tingkat kemunculan berbagai kondisi atau atribut untuk menilai pengendalian internal. Misalnya, auditor internal menguji sampel atribut apakah dokumen faktur telah 
menerima tanda tangan persetujuan yang tepat. Faktur disetujui dengan benar atau tidak. Biasanya, atribut yang diukur adalah frekuensi kesalahan atau jenis kekurangan lainnya. Tingkat keberadaan defisiensi khusus, seperti dokumen yang disetujui secara tidak tepat, keseriusan situasi ini menentukan bagaimana auditor internal akan melaporkan temuan dan rekomendasinya. Atribut dapat diterapkan pada;

a. benda fisik,

b. catatan keuangan,

c. prosedur internal, atau

d. kegiatan operasional apa pun.

Pengambilan sampel atribut sering mengukur kepatuhan terhadap kebijakan, prosedur, atau standar yang ditetapkan, dan dapat menjadi ujian yang kuat yaitu berfungsi atau tidak pengendalian internal.

\section{Sampel Variabel}

Pengambilan sampel variabel berkaitan dengan ukuran populasi tertentu, seperti saldo akun atau tes dalam item sampel individu. Di sini fokus auditor adalah pada "seberapa banyak" yang bertentangan dengan fokusdari sampel variabel. Tujuan dari pengambilan sampel variabel adalah untuk memproyeksikan jumlah taksiran total untuk beberapa akun atau penyesuaian ke akun berdasarkan sampel statistik. Pengambilan sampel variabel berkaitan dengan jumlah absolut yang bertentangan dengan jumlah atau tingkat jenis kesalahan tertentu.

\section{Sampel Penemuan}

Jenis ketiga sampling statistik, sampling penemuan, mirip dengan sampling penilaian nonstatistik yang dibahas 
sebelumnya. Sampel penemuan digunakan ketika auditor internal ingin menarik sampel dari volume data yang besar tanpa proses statistik yang terkait dengan variabel dan sampling atribut.

\section{F. Prosedur Pengambilan Sampel Atribut}

Auditor menguji jumlah item yang memiliki beberapa jenis kesalahan signifikan, bukan total nilai moneter dari semua kesalahan. Jenis tes ini sangat tepat untuk menilai tingkat pengendalian intern dalam beberapa akun tertentu, dan dapat menjadi pendekatan yang sangat penting untuk uji pengendalian intern Sarbanes-Oxley Act (SOx) Bagian 404 (Sarbanes, 2010b). Tahapan rencana sampling audit:

a. Menentukan tujuan audit

b. Merumuskan populasi dan unit sampling

c. Menetapkan atribut-atribut

d. Menentukan ukuran sample

e. Menentukan metoda pemilihan sampel

f. Melaksanakan rencana sampling

g. Mengevaluasi hasil sampling

Tujuan utama pengujian pengendalian adalah mengevaluasi keefektifan rancangan dan pengoperasian pengendalian internal.

Titik awal dalam atribut sampling adalah memperkirakan tingkat kesalahan yang diharapkan yaitu, berapa banyak kesalahan yang bisa ditoleransi oleh audit dan manajemen internal. Bergantung pada item yang diambil sampel dan budaya perusahaan, tingkat kesalahan yang diharapkan ini mungkin hanya $0,01 \%$ atau sebesar $5 \%$. Bahkan jika manajemen senior menyatakan bahwa tidak ada kesalahan yang diizinkan dalam beberapa operasi yang sangat kritis. 
Tingkat kesalahan yang diharapkan adalah pengakuan bahwa jenis operasi tertentu mengandung kesalahan tidak peduli sebagus apa pun pengendalian dan prosedurnya. Jika auditor internal melakukan pemeriksaan $100 \%$ terhadap akun tetapi hanya menemukan sedikit kesalahan misalnya, 0,5\% mungkin sulit untuk meyakinkan manajemen bahwa pengendaliannya lemah. Jika manajemen mentolerir tingkat kesalahan $1 \%$ maka kesalahan 0,5\% dicatat dalam laporan audit sebagai memadai.

Seiring dengan memperkirakan tingkat kesalahan yang diharapkan, audit internal harus memutuskan batas presisi yang dapat diterima dan tingkat kepercayaan yang diinginkan untuk sampel misalnya 99\% ini berarti tingkat kesalahan kurang paling besar adalah $1 \%$. Penentuan ini dilakukan melalui metode statistik dan dapat diperoleh dari berbagai paket perangkat lunak statistik.

Jika sampel menunjukkan tingkat kesalahan lebih rendah dari yang diharapkan, auditor internal menetapkan bahwa kondisi yang diuji aman dalam batas yang dipilih. Apabila sampel menunjukkan tingkat kesalahan yang lebih tinggi, auditor harus menentukan bahwa kondisi yang diuji kurang memuaskan dan menetapkan apa tindakan lebih lanjut yang diperlukan. Intinya pengambilan sampel atribut yang bermakna adalah untuk mengambil sampel yang sesuai untuk mengembangkan kesimpulan audit berdasarkan hasil sampel.

\section{G. Melakukan Tes Pengambilan Sampel Atribut}

Auditor harus terlebih dahulu membuat beberapa perkiraan awal berdasarkan pengamatan, kemudian menarik sampel audit berdasarkan harapan tersebut. Auditor internal perlu memperkirakan tingkat kesalahan maksimum yang dapat ditoleransi, tingkat kepercayaan sampel yang diinginkan, tingkat 
kesalahan perkiraan populasi, dan kemudian ukuran sampel awal. Parameter pengambilan sampel atribut adalah:

a. Tingkat kesalahan maksimum yang bisa ditoleransi. Para ahli statistik juga menyebut perkiraan ini sebagai batas presisi atas kesalahan yang diijinkan sehingga auditor internal sementara masih menerima pengendalian intern keseluruhan. Misalnya dalam audit laporan pengeluaran perjalanan yang ditinjau untuk persetujuan manajemen departemen, auditor internal yang realistis mengakui bahwa mungkin ada beberapa kesalahan, seperti voucher Rp 25,01 yang di atas persyaratan Rp 25,00. Ini adalah kesalahan yang mungkin diterima oleh auditor internal tetapi masih merasa bahwa pengendalian internal umumnya memadai.

b. Tingkat kepercayaan yang diinginkan. Ini adalah ukuran kepercayaan auditor pada hasil sampel. Artinya, auditor internal umumnya ingin kepastian $95 \%$ atau $98 \%$ bahwa hasil sampel mewakili populasi aktual.

c. Estimasi tingkat kesalahan populasi. Untuk menghitung ukuran sampel, auditor internal juga perlu memperkirakan tingkat yang diharapkan dari kesalahan dalam populasi. Misalnya, jika tingkat kepercayaan $95 \%$ dan tingkat kesalahan maksimum yang dapat ditoleransi adalah $5 \%$.

d. Ukuran sampel awal. Tiga faktor sebelumnya, bersama dengan beberapa faktor koreksi statistik, akan menentukan ukuran sampel yang diperlukan. auditor internal biasanya menggunakan perangkat lunak audit untuk mengembangkan rencana pengambilan sampel atribut. 
Contoh, dengan populasi 1.000-item dan keandalan yang diinginkan sebesar 3\%, auditor internal harus menarik sampel 260 item dengan tingkat keparcayaan 99\% dan tingkat kesalahan tidak lebih dari 5\%. Ukuran sampel ini akan menjadi jauh lebih kecil jika tingkat kepercayaan diturunkan dari 99\% menjadi $95 \%$.

\begin{tabular}{|c|c|c|c|c|c|c|}
\hline Ukuran Populasi & $\begin{array}{l} \pm \\
1 \%\end{array}$ & $\begin{array}{l} \pm \\
1,5 \%\end{array}$ & $\pm 2 \%$ & $\begin{array}{l} \pm \\
2,5 \%\end{array}$ & $\begin{array}{l} \pm \\
3 \%\end{array}$ & $\begin{array}{l} \pm \\
4 \%\end{array}$ \\
\hline 200 & & & & & & 99 \\
\hline 250 & & & & & & 110 \\
\hline 300 & & & & & & 119 \\
\hline 350 & & & & & 175 & 126 \\
\hline 400 & & & & & 187 & 132 \\
\hline 450 & & & & & 197 & 137 \\
\hline 500 & & & & & 206 & 142 \\
\hline 550 & & & & 263 & 214 & 145 \\
\hline 600 & & & & 274 & 221 & 148 \\
\hline 650 & & & & 284 & 228 & 151 \\
\hline 700 & & & & 293 & 234 & 154 \\
\hline 750 & & & & 302 & 239 & 156 \\
\hline 800 & & & 397 & 310 & 244 & 158 \\
\hline 850 & & & 409 & 318 & 248 & 160 \\
\hline 900 & & & 420 & 324 & 252 & 162 \\
\hline 950 & & & 431 & 330 & 256 & 163 \\
\hline 1000 & & & 441 & 336 & 260 & 165 \\
\hline 1050 & & 419 & 450 & 341 & 263 & 116 \\
\hline 1100 & & 422 & 459 & 346 & 266 & 197 \\
\hline
\end{tabular}

Gambar 8.1 Contoh Ukuran Atribut (Keandalan Ukuran Sampel): Sumber : ( Moeller. R.R,2016) 


\section{H. Memilih Sampel untuk Melakukan Prosedur Audit}

Setelah membuat beberapa asumsi sampel audit dan menentukan ukuran sampel, langkah selanjutnya adalah auditor internal menarik item-item aktual untuk ditinjau (AICPA, 2015). Prosedur pengambilan sampel acak dapat digunakan untuk memilih item yang akan ditinjau. Berbagai atribut juga dapat diuji menggunakan set item sampel yang sama.

Dokumentasi kertas kerja harus menggambarkan semua item yang dipilih sebagai bagian dari pengujian atribut. Perangkat lunak lembar kerja berguna di sini untuk mencatat hasil tes audit, tetapi prosedur audit internal harus dilakukan dengan sangat hati-hati. Jika audit gagal mengenali kondisi kesalahan dalam item sampel yang dipilih, fakta itu akan membuang kesimpulan yang dicapai sebagai bagian dari keseluruhan sampel.

Setiap item sampel harus dievaluasi dengan cermat dan konsisten terhadap atribut yang ditetapkan. Jika beberapa pengukuran atribut terlalu ketat untuk item tertentu, audit internal harus mempertimbangkan untuk mengevaluasi kembali seluruh set sampel. Auditor internal mungkin mencari beberapa kondisi kesalahan tetapi kemudian menemukan kesalahan lain yang tidak termasuk dalam desain tes. Jika kesalahan lain tersebut signifikan, audit internal sebaiknya mendefinisikan ulang tes atribut keseluruhan.

\section{Mengevaluasi Hasil Uji Sampling Atribut}

Untuk memilih dan mengevaluasi item sampel yang tepat, auditor internal membuat langkah-langkah diantaranya;

a. asumsi awal mengenai tingkat kesalahan maksimum yang dapat ditoleransi, keandalan, dan tingkat kepercayaan, 
serta tentang berapa banyak kesalahan kepatuhan akan ditoleransi untuk menilai apakah pengendaliannya memadai.

b. mengevaluasi hasil sampel terhadap asumsi-asumsi tersebut untuk menentukan apakah ada masalah pengendalian internal.

c. menilai tingkat kesalahan aktual dari item sampel dan menghitung batas presisi berdasarkan kesalahan sampel tersebut. Batas presisi dihitung berdasarkan sampel aktual, harus kurang dari atau sama dengan batas presisi yang ditetapkan pada awal agar auditor mendapatkan sampel menguntungkan.

Biasanya, jika hasil sampel tidak memenuhi kriteria awal, kondisi ini berpengaruh pada temuan audit utama. Sementara kriteria audit harus disetujui menejemen senior audit sebelum memulai pengujian, sehingga audit internal atau manajemen dapat memutuskan bahwa asumsi awal terlalu konservatif. Jika dianggap konservatif auditor internal bisa mengubah kreteria sampel agar hasil sampel lebih baik. Peningkatan ukuran sampel audit internal harus mempertimbangkan biaya dan manfaat. Dengan pertimbangan biaya dan manfaat biasanya audittor tidak merubah kreteria sampel. Namun, melaporkan masalah pengendalian intern berdasarkan hasil saat ini dan memperluas ukuran sampel dalam tinjauan audit berikutnya. Diharapkan manajemen akan mengambil langkah-langkah sementara untuk meningkatkan pengendalian intern di bidang yang diaudit.

Pengambilan sampel atribut adalah teknik yang sangat berguna untuk menilai satu atau beberapa pengendalian intern dalam bidang yang menjadi fokus unit audit. Karena perkiraan hal- 
hal seperti tingkat kesalahan maksimum yang dapat ditoleransi dibuat di muka, sulit untuk membantah asumsi uji audit bila dibandingkan dengan hasil sampel. Demikian pula, karena angka acak atau teknik serupa biasanya digunakan untuk memilih item sampel, akan sulit untuk mengklaim bias auditor dalam seleksi.

\section{J. Keunggulan dan Kelemahan Sampel Atribut}

Ketika ada kebutuhan untuk meninjau sejumlah besar item, prosedur pengambilan sampel atribut dapat memberikan penilaian yang akurat secara statistik dari atribut. Meskipun teori statistik memerlukan ukuran sampel yang relatif besar, audit internal dapat meninjau beberapa pengendalian atau kondisi dalam sampel data dan kemudian dapat menyatakan bahwa data dapat dipercaya, dalam persentase kepercayaan yang telah ditetapkan sebelumnya, bahwa jumlah kesalahan dalam total populasi tidak akan melebihi nilai yang ditentukan.

Pengambilan sampel atribut tidak berguna untuk menentukan estimasi nilai yang benar pada akun seperti nilai buku inventaris, tetapi merupakan alat yang sangat berguna untuk meninjau prosedur pengendalian di berbagai bidang operasional. Beberapa auditor internal merasa teknik ini memiliki beberapa kendala dalam penggunaannya, termasuk:

a. Perhitungan sampling atribut bersifat kompleks. Tinjauan aktual dan analisis hasil sampel bisa sangat kompleks memerlukan penggunaan perangkat lunak pengambilan sampel yang kompleks.

b. Definisi atribut yang tepat mungkin sulit. Dalam contoh catatan sumber daya manusia sebelumnya, audit internal mengambil sampel dan mengevaluasi pengendalian pada lima atribut yang dipilih dari 30 atribut aktual sehingga ada 
kemungkinan auditor melawatkan satu atau beberapa atribut yang penting pada saat analisis data.

c. Data tidak sempurna memerlukan koreksi. Jika distribusi data yang tidak standar dapat diperbaiki melalui penyesuaian dalam pemilihan ukuran sampel dan evaluasi, distribusi yang tidak normal mempersulit proses analisisdata.

Terlepas dari masalah ini, atribut sampling melengkapi audit internal dengan alat yang sangat kuat untuk menilai pengendalian internal dalam populasi data yang besar melalui evaluasi sampel terbatas. Teknik ini sangat tepat ketika hasil awal, penilaian dari tinjauan pengendalian internal menunjukkan masalah di suatu atribut. Ketika manajemen membantah hasil awal dari sampel audit terbatas tindak lanjut memungkinkan audit internal untuk melihat kembali data dan kembali membuat pernyataan yang lebih kuat tentang status pengendalian internal di sekitar atribut yang berselisih.

\section{K. Sampling Unit Moneter}

Pengambilan sampel unit moneter adalah teknik untuk menentukan apakah suatu akun keuangan dinyatakan secara adil, ini merupakan metode yang baik untuk memperkirakan jumlah overstatements akun apa pun. Konsepnya adalah bahwa setiap rupiah dalam suatu akun diperlakukan sebagai anggota populasi dan masing-masing memiliki peluang untuk dipilih. Misalnya Voucher Rp 1.000 untuk akun yang memiliki 1.000 unit populasi, sedangkan voucher Rp 100 untuk akun yang sama memiliki 100 populasi. Dengan demikian item Rp 1.000 dalam populasi memiliki peluang 1.000 kali lebih besar untuk pemilihan sampel daripada item Rp 1. 
Misalnya, jika pembelian sedang diuji selama satu tahun, populasi sampel unit moneter terdiri dari total nilai nilai rupiah dari pembelian yang dilakukan, dan unit pengambilan sampel akan menjadi setiap nilai rupiah pembelian. Jika kesalahan ditemukan dalam faktur, terkait dengan nilai rupiah individu dalam faktur ini menggunakan berbagai metode evaluasi.

\section{Contoh Memilih Sampel Unit Moneter}

Asumsikan bahwa audit internal ingin meninjau serangkaian saldo piutang untuk menentukan apakah saldo piutang dinyatakan secara wajar atau dicatat. Juga asumsikan ada 1.364 item atau saldo pelanggan dalam akun, dengan total saldo yang tercatat $\mathrm{Rp} 54,902.25$. Saldo pelangan terdiri dari beberapa jumlah besar dan yang lain jumlahnya sangat kecil.

Asumsikan bahwa audit internal pada awalnya telah memutuskan ukuran sampel 60 atau untuk melihat hanya 60 rupiah per orang dan barang-barang yang diwakili oleh nilai rupiah ini. Dengan sampel ini, auditor internal dapat melihat Rp 54,902.25 / 60 = Rp 915.034 atau setiap 915 rupiah dalam saldo akun. Setiap kali item yang termasuk dalam salah satu rupiah itu dipilih, auditor akan memeriksa keseluruhan item itu.

Gambar 7.2 memiliki kolom untuk nomor akun (1 sd 30), untuk masing-masing akun dan total kumulatif. Kolom tambahan dalam gambar ini menunjukkan proses pemilihan unit moneter, sebagai berikut:

a. Meskipun auditor akan memilih setiap Rp 915, titik awal antara Rp1 dan Rp 915 harus dipilih nomor acak awal antara 1 dan 915 dipilih jumlahnya 37. 
b. Angka acak awal, 37, kemudian ditambahkan ke faktur pertama sejumlah Rp 123,58, dibulatkan menjadi 124 menghasilkan 161. Karena 161 kurang dari 915, item berikutnya, 754, ditambahkan ke nilai akumulasi untuk menghasilkan 1039. Di sini, auditor akan menemukan rupiah ke-915, dan item ini dipilih untuk ditinjau.

c. Nomor awal yang baru sekarang diperlukan 915 dikurangi dari 1039 untuk menghitung angka awal untuk item berikutnya, 124. Ini ditambahkan ke item ketiga, 589 , untuk menghasilkan 713, tidak cukup untuk seleksi.

d. Item keempat dalam sampel ini besar, 2056. Interval 915 muncul dua kali dalam aliran rupiah ini $(915 \times 2=1830)$ dan item tersebut adalah seleksi untuk dua item sampel.

Tujuannya hanya untuk menentukan interval moneter berdasarkan ukuran sampel yang dihitung. Keterbatasan pengambilan sampel unit moneter, antara lain.

a. Pertama, Pengambilan sampel unit moneter tidak akan pernah memilih akun yang salah dicatat pada nilai nol rupiah

b. Kedua, metode seleksi yang dijelaskan tidak menangani jumlah kredit dengan benar, sehingga prosedur pemilihan sampel itu sendiri tidak akan berfungsi dengan benar jika akun memasukkan sejumlah besar item kredit.

\section{Melakukan Uji Sampel Unit Moneter}

Jumlah nilai rupiah yang akan diperiksa dalam suatu populasi menentukan ukuran sampel auditor. Mirip dengan atribut sampling, tes unit moneter mensyaratkan empat hal tentang akun yang akan diambil sampelnya: 


\begin{tabular}{|c|c|c|c|c|c|c|}
\hline $\begin{array}{l}\text { Acct } \\
\text { No. }\end{array}$ & Saldo & $\begin{array}{l}\text { Akum } \\
\text { saldo }\end{array}$ & $\begin{array}{l}\text { Perhitun } \\
\text { gan } \\
\text { mulai }\end{array}$ & Mulai & $\begin{array}{l}\text { Pembu } \\
\text { latan } \\
\text { saldo }\end{array}$ & $\begin{array}{l}3+4= \\
>915 \\
\text { diselek } \\
\text { si (S) }\end{array}$ \\
\hline & 1 & 2 & & 3 & 4 & $\begin{array}{l}5=(3 \\
+4)\end{array}$ \\
\hline 1 & 123.58 & 123.58 & & $37+$ & $124=$ & 161 \\
\hline 2 & 754.22 & 877.80 & & $161+$ & $878=$ & $1039 \mathrm{~S}$ \\
\hline 3 & 588.85 & $1,466.65$ & $\begin{array}{l}1039- \\
915\end{array}$ & $124+$ & $589=$ & 713 \\
\hline 4 & $2,055.95$ & $3,522.60$ & & $713+$ & $2056=$ & $2769 \mathrm{~S}$ \\
\hline 5 & 341.00 & $3,863.60$ & $\begin{array}{l}2769- \\
1830=9 \\
39\end{array}$ & $939+$ & $341=$ & $1280 \mathrm{~S}$ \\
\hline 6 & 855.20 & $4,718.80$ & $\begin{array}{l}1280- \\
915=36 \\
5\end{array}$ & $365+$ & $855=$ & $1220 \mathrm{~S}$ \\
\hline 7 & 12.55 & $4,731.35$ & $\begin{array}{l}1220=9 \\
15-305\end{array}$ & $305+$ & $13=$ & 318 \\
\hline 8 & 89.00 & $4,820.35$ & & $318+$ & $89=$ & 407 \\
\hline 9 & 250.00 & $5,070.35$ & & $407+$ & $250=$ & 657 \\
\hline 10 & $1,099.30$ & $6,169.65$ & & $657+$ & $1099=$ & $1756 \mathrm{~S}$ \\
\hline 11 & 87.33 & $6,256.98$ & $\begin{array}{l}1756- \\
915=84 \\
1\end{array}$ & $841+$ & $87=$ & $9238 \mathrm{~S}$ \\
\hline 12 & 788.99 & $7,045.97$ & & $8+$ & $789=$ & 797 \\
\hline 13 & $5,892.10$ & $12,938.07$ & & $797+$ & $5892=$ & $6689 \mathrm{~S}$ \\
\hline 14 & 669.90 & $13,607.97$ & & $284+$ & $670=$ & $954 \mathrm{~S}$ \\
\hline
\end{tabular}




\begin{tabular}{|l|l|l|l|l|l|l|}
\hline 15 & 24.89 & $13,632.86$ & $\begin{array}{l}954- \\
915=39\end{array}$ & $39+$ & $25=$ & 64 \\
\hline 16 & 123.00 & $13,755.86$ & & $64+$ & $123=$ & 187 \\
\hline 17 & 123.00 & $13,878.86$ & & $187+$ & $123=$ & 310 \\
\hline 18 & 6.00 & $13,884.86$ & & $310+$ & $6=$ & 316 \\
\hline 19 & 540.90 & $14,425.76$ & & $316+$ & $541=$ & 857 \\
\hline 20 & 100.50 & $14,526.26$ & & $857+$ & $101=$ & $958 \mathrm{~S}$ \\
\hline 21 & 66.89 & $14,593.15$ & & $43+$ & $67=$ & 110 \\
\hline 22 & 39.00 & $14,632.15$ & & $110+$ & $39=$ & 149 \\
\hline 23 & 35.00 & $14,667.15$ & & $149+$ & $35=$ & 184 \\
\hline 24 & 89.00 & $14,756.15$ & & $184+$ & $89=$ & 273 \\
\hline 25 & 100.00 & $14,856.15$ & & $273+$ & $100=$ & 373 \\
\hline 26 & 53.90 & $14,910.05$ & & $373+$ & $54=$ & 427 \\
\hline 27 & 436.09 & $15,346.14$ & & $427+$ & $436=$ & 863 \\
\hline 28 & 237.76 & $15,583.90$ & & $863+$ & $238=$ & $1101 \mathrm{~S}$ \\
\hline 29 & 209.91 & $15,793.81$ & $\begin{array}{l}1101- \\
915\end{array}$ & $186+$ & $210=$ & 396 \\
\hline 30 & 28.89 & $15,822.70$ & & $396+$ & $29=$ & 425 \\
\hline & Starting Random = 37 & & & \\
\hline & Interval Selection =915 & & & \\
\hline & Total Sample Items Selected =10 & & \\
\hline
\end{tabular}

Gambar 8.2 Contoh Pengambilan Sampel Unit Moneter Sumber : ( Moeller. R.R, 2016)

a. Persentase maksimum dari nilai populasi yang dicatat akan ditoleransi oleh auditor atas kesalahan. Ini adalah batas presisi yang dibahas sebelumnya untuk pengambilan sampel atribut.

b. Tingkat kepercayaan yang diharapkan. 
c. Tingkat kesalahan yang diharapkan untuk pengambilan sampel.

d. Total nilai yang dicatat dari akun yang akan dievaluasi.

Item pertama uji moneter adalah nilai rupiah dari populasi yang mungkin mengandung kesalahan yang dibolehkan dibagi dengan nilai buku yang tercatat dari populasi. Ini adalah estimasi yang sama yang dibahas sebelumnya untuk atribut sampling, tingkat kesalahan yang dapat ditoleransi oleh auditor internal dan masih menerima pengendalian keseluruhan dalam sistem. Seorang auditor internal harus terlebih dahulu memikirkan jumlah total kesalahan material yang akan diterima. Meskipun angka ini dapat dihitung, umumnya tingkat persentase kecil misalnya $2 \%$ digunakan.

Tingkat kepercayaan seringkali $98 \%$ atau 95\%. Tingkat kepercayaan berpengaruh terhadap jumlah data untuk menentukan ukuran sampel yang disarankan. Data dapat diperoleh dari tabel atau dari perangkat lunak sampling statistik. Nilai dalam gambar 7.1, berdasarkan tingkat kepercayaan 95\%, dapat digunakan di sini. Sampling unit moneter merupakan area di mana beberapa akuntan publik menggunakan ukuran sampel tetap dari 60 atau kadangkadang 30, dengan alasan bahwa matematika tidak memerlukan ukuran sampel yang lebih besar.

Ukuran sampel unit moneter kemudian digunakan untuk menghitung interval moneter dengan membagi nilai buku yang direkam dari akun dengan ukuran sampel untuk menentukan interval nilai rupiah ke-n. Interval ini menetapkan batas pilihan untuk item yang lebih besar dan 
semua item yang lebih besar dari atau sama dengan interval ini akan dipilih. Setiap item yang diwakili oleh nilai rupiah yang dipilih kemudian dievaluasi oleh auditor untuk menentukan apakah dinyatakan dengan benar. Auditor menghitung jumlah yang benar untuk setiap akun yang dipilih dan mencatat jumlah yang diaudit dengan benar. Ini akan menunjukkan seberapa besar setiap akun dilebih-lebihkan.

\section{Mengevaluasi Hasil Sampel Unit Moneter}

Pengambilan sampel unit moneter adalah pendekatan yang efektif untuk mengevaluasi saldo akun untuk menentukan apakah saldo akun telah dilebih-lebihkan. Karena setiap nilai rupiah dalam setiap item dalam akun akan tunduk pada pemilihan sampel, item yang berlebihan dapat ditemukan selama proses pengambilan sampel. Evaluasi hasil pengambilan sampel unit moneter untuk memperkirakan kesalahan total dalam akun adalah proses yang lebih kompleks. Ide dasarnya adalah mendokumentasikan jumlah yang tercatat dan jumlah yang diaudit untuk setiap item yang dipilih dan kemudian menghitung persentase kesalahan untuk masing-masing. Batas presisi dihitung untuk setiap item kesalahan untuk menentukan jumlah yang disarankan dari setiap penyesuaian audit.

Perhitungan untuk evaluasi sampel unit moneter memiliki serangkaian opsi statistik. Proses ini seringkali lebih menarik bagi auditor eksternal, dapat menggunakan ini untuk mengusulkan penyesuaian terhadap laporan keuangan klien yang diaudit. Untuk auditor internal, seringkali cukup untuk menggunakan hasil dari item yang dipilih melalui pengambilan sampel unit moneter untuk mendapatkan 
penilaian keseluruhan, apakah suatu akun dinyatakan dengan benar.

\section{Kelebihan dan Keterbatasan Sampel Unit Moneter}

Kelebihan paling penting dari pengambilan sampel satuan moneter adalah;

a. fokus pada item satuan bernilai lebih besar dalam suatu populasi.

b. ada sedikit risiko gagal mendeteksi kesalahan material karena semua unit nilai rupiah besar dapat dipilih berdasarkan ukuran masing-masing. Item apa pun dalam populasi yang lebih besar dari interval moneter akan selalu dipilih.

c. Pengambilan sampel unit moneter memastikan bahwa akan ada cakupan yang lebih besar dari item bernilai lebih besar dalam suatu populasi.

d. jika tidak ada kesalahan ditemukan dalam sampel awal dan tingkat kesalahan yang diharapkan dibuat sangat rendah, ukuran sampel yang relatif kecil dapat digunakan.

e. Auditor internal dapat dengan mudah membatasi ukuran sampel dalam situasi ini. Sebagaimana dibahas, akuntan publik sering membatasi ukuran sampel unit moneternya menjadi 60 atau 30 item.

f. Auditor internal memperoleh manfaat stratifikasi tanpa batas dengan menggunakan unit pengambilan sampel moneter.

g. Pengambilan sampel unit moneter juga menarik karena pemilihan item mudah secara komputasi. 
Kekurangan utama dari pengambilan sampel unit moneter adalah

a. Bahwa prosedur tidak cukup menguji untuk pernyataan laporan keuangan.

b. Dokumen atau transaksi yang hilang adalah masalah umum dalam sistem yang tidak terpengendalian

c. Jika barang hilang pada populasi, prosedur pengambilan sampel unit nilai rupiah tidak akan mendeteksi barang yang hilang.

d. Nilai nol atau negatif menyebabkan masalah karena tidak ada kemungkinan nilai rupiah tersebut akan dijadikan sampel.

e. Nilai buku total harus diketahui untuk membuat perhitungan interval.

f. Metode ini tidak dapat memberikan perkiraan nilai populasi yang tidak diketahui

Terlepas dari keterbatasan ini, pengambilan sampel satuan moneter sering kali merupakan metode terbaik untuk kesalahan audit dalam beberapa nilai buku yang tercatat. Ini juga dapat berguna sebagai metode seleksi untuk uji atribut pengendalian internal ketika semua item dalam populasi memiliki beberapa nilai moneter yang tercatat. Pendekatan ini sering lebih unggul daripada pemilihan nomor acak yang telah dibahas sebelumnya dan akan menghasilkan pemilihan yang sangat tepat.

\section{Membuat Sampling Audit Yang Efisien dan Efektif}

Sampling audit adalah bagian penting bagi auditor internal, tetapi tidak selalu merupakan persyaratan penting untuk dimasukkan dalam semua audit. Auditor internal mungkin tidak 
memutuskan untuk menguji transaksi ketika melakukan audit. Auditor internal memutuskan, berdasarkan perbandingan keseluruhan dan prosedur audit lainnya, bahwa pengujian transaksi tidak diperlukan atau bahwa jumlah yang terlibat tidak cukup material untuk menjamin pengujian. Namun, auditor internal sering dihadapkan dengan situasi memerlukan pengambilan sampel transaksi. Sistem pengendalian terbaik tidak dapat menghilangkan kesalahan yang terjadi dari gangguan sistem, dan keseluruhan pengujian beberapa transaksi mungkin tidak cukup untuk mengungkapkan apakah pengendalian internal beroperasi secara efektif.

Sementara prosedur mungkin tampak memadai, auditor internal umumnya harus menguji transaksi aktual untuk menentukan apakah prosedur tersebut telah diikuti dalam praktik. Jika tes dilakukan, pengambilan sampel audit harus dipertimbangkan sebagai dasar untuk sampai pada kesimpulan yang lebih valid. Jika tes transaksi yang dihasilkan melalui sampel audit menunjukkan bahwa operasi dapat diterima, tidak ada pekerjaan lebih lanjut yang diperlukan. Ketika kesalahan ditemukan, auditor internal umumnya dihadapkan dengan keputusan berikut untuk sampai pada kesimpulan audit:

a. Mengisolasi kesalahan. Melalui peninjauan jenis kesalahan dan penyebabnya, auditor internal mungkin dapat mengisolasi jumlah total kesalahan.

b. Melaporkan hanya pada item yang diperiksa. Ketika seorang auditor internal menghadapi kesalahan yang signifikan, mungkin hanya perlu melaporkan hasil tes kepada personel yang beroperasi. Sifat kesalahan dapat sedemikian rupa sehingga merupakan tanggung jawab manajer operasional 
untuk memperkuat prosedur dan menentukan besarnya kesalahan. Sebagai bagian dari tinjauan ini, auditor internal harus berusaha untuk menentukan yang menyebabkan kondisi tersebut dan membuat rekomendasi spesifik untuk tindakan korektif..

c. Melakukan audit $\mathbf{1 0 0} \%$. Meskipun auditor internal biasanya tidak akan melakukan pemeriksaan terperinci atas semua transaksi, terkadang ada kebutuhan untuk pemeriksaan lanjutan ketika kesalahan signifikan ditemukan. Jika rencana pengambilan sampel harus didasarkan pada tingkat kepercayaan yang sangat tinggi, mungkin lebih besar dari $99 \%$, dan risiko rendah mungkin $1 \%$. Ukuran sampel besar ini atau pemeriksaan $100 \%$ mungkin tidak dapat dibenarkan dalam hal biaya, dan rencana sampling statistik yang lebih konvensional mungkin cukup.

d. Memproyeksikan hasil sampel. Jika pemilihan item untuk tes dilakukan secara acak, hasilnya dapat dievaluasi menggunakan tabel statistik. Jumlah total dan jumlah kesalahan nilai rupiah dapat diproyeksikan untuk menentukan rentang kesalahan di seluruh bidang pada tingkat kepercayaan yang diberikan.

Teknik-teknik berikut memfasilitasi penggunaan sampling audit untuk prosedur audit:

a. Gabungkan langkah-langkah audit. Penghematan waktu audit dapat dicapai jika berbagai langkah audit dilakukan sebagai bagian dari sampel statistik yang sama. Ini dapat dilakukan dengan menguji sebanyak mungkin atribut atau karakteristik dalam sampel 
b. Gunakan sampel pendahuluan. Auditor dapat mencurahkan banyak upaya untuk mengembangkan rencana pengambilan sampel berdasarkan estimasi tingkat kepercayaan, presisi, dan tingkat kesalahan yang diharapkan atau standar deviasi; Namun, dalam banyak kasus ada informasi yang tidak memadai dalam audit pertama untuk mengembangkan rencana pengambilan sampel. Dengan mengambil sampel awal 50 hingga 100 item, auditor internal berada dalam posisi yang lebih baik untuk membuat keputusan tentang sejauh mana pengambilan sampel diperlukan. Sampel pendahuluan kemudian dapat dimasukkan sebagai bagian dari sampel akhir, dan hasil sampel pendahuluan dapat digunakan auditor internal untuk menyimpulkan bahwa tidak diperlukan pengujian lebih lanjut.

c. Lakukan audit sementara. Ketika rencana pengambilan sampel dipersiapkan sebelumnya barang yang akan diuji dapat diperiksa secara bulanan tanpa menunggu sampai akhir tahun. Dengan demikian, staf auditor dapat digunakan saat tersedia untuk melakukan pengambilan sampel audit secara sementara. Misalnya, jika paket sampel meminta pemeriksaan setiap voucher ke seratus, ini dapat dipilih untuk diperiksa saat transaksi diproses.

d. Memperbesar ukuran bidang. Pertimbangan dasar dalam pengambilan sampel audit adalah bahwa ukuran sampel tidak boleh bervariasi dengan peningkatan ukuran bidang. Dengan demikian penghematan dapat diperoleh dengan mengambil sampel untuk periode waktu yang lebih lama, atau dari bidang yang terdiri dari lebih dari satu departemen atau divisi. Dalam beberapa kasus, auditor internal dapat 
memutuskan untuk menguji akun tertentu untuk periode dua tahun, dengan pemilihan item selama tahun pertama secara interim sebagai bagian dari tes dua tahun itu.

e. Terapkan metode pengambilan sampel audit sederhana. Dalam kebanyakan kasus, sampel estimasi sederhana akan memberikan hasil yang memadai, tanpa perlu teknik yang sulit untuk dipahami, diterapkan, dan dijelaskan. Auditor internal tidak boleh mengabaikan sampling penilaian dalam tes audit, dan item sensitif harus diperiksa selain pemilihan item acak..

f. Mencapai keseimbangan efektif antara biaya dan manfaat audit. Auditor internal harus mempertimbangkan biaya untuk memeriksa setiap unit pengambilan sampel ketika mempertimbangkan untuk memperluas sampel.

Audit sampling adalah alat yang ampuh yang terlalu sering diabaikan oleh banyak auditor internal. Di masa lalu, auditor tidak menggunakan sampling audit karena dianggap terlalu sulit atau terlalu teoretis. Auditor merasa lebih mudah untuk mengatakan, "Anda punya masalah di sini," dari pada mengatakan, "Berdasarkan sampel audit kami, kami yakin 95\% bahwa kami telah mengidentifikasi masalah pengendalian." Perangkat TI sekarang menjadikan pengambilan sampel statistik sebagai tugas yang lebih sederhana daripada di hari-hari sebelumnya ketika auditor mengandalkan tabel nilai yang luas dan formula yang sulit (Jusup, 2001).

\section{Simpulan}

Bukti yang dikumpulkan oleh auditor internal harus relevan karena merupakan salah satu bagian dari rangkaian bukti-bukti (chain of evidence) yang menggambarkan suatu proses kejadian 
atau jika bukti tersebut secara tidak langsung menunjukkan kenyataan dilakukan atau tidak dilakukannya suatu perbuatan. Sampling statistik merpakan alat yang baik memilih item yang representatif yang mencerminkan karakteristik seluruh populasi. Dengan menggunakan hasil tes audit pada item yang diambil secara statistik, auditor internal kemudian dapat menyatakan pendapat tentang seluruh kelompok.

Jika sampel menunjukkan tingkat kesalahan lebih rendah dari yang diharapkan, auditor internal menetapkan bahwa kondisi yang diuji aman dalam batas yang dipilih. Apabila sampel menunjukkan tingkat kesalahan yang lebih tinggi, auditor harus menentukan bahwa kondisi yang diuji kurang memuaskan dan menetapkan apa tindakan lebih lanjut yang diperlukan. Intinya pengambilan sampel atribut yang bermakna adalah untuk mengambil sampel yang sesuai untuk mengembangkan kesimpulan audit berdasarkan hasil sampel. Pengambilan sampel atribut digunakan untuk mengukur tingkat kemunculan berbagai kondisi atau atribut untuk menilai pengendalian internal. Biasanya, atribut yang diukur adalah frekuensi kesalahan atau jenis kekurangan lainnya.

Sampling unit moneter merupakan area di mana beberapa akuntan publik menggunakan ukuran sampel tetap dari 60 atau kadang-kadang 30, dengan alasan bahwa matematika tidak memerlukan ukuran sampel yang lebih besar. Karena setiap nilai rupiah dalam setiap item dalam akun akan tunduk pada pemilihan sampel, item yang berlebihan dapat ditemukan selama proses pengambilan sampel. 


\section{N. Contoh Kasus Mennguji, Menilai dan Mengevaluasi Bukti Audit.} Secara khusus, mengingat sistem $\mathrm{TI}$ saat ini, auditor internal memerlukan beberapa cara untuk meninjau data besar (big data) yang terkomputerisasi ini. Ada tantangan utama audit internal di sini. Auditor internal memerlukan pendekatan yang konsisten untuk mengambil sampel sebagian item dari populasi data yang besar dan kemudian untuk menarik kesimpulan audit berdasarkan sampel terbatas tersebut. Tantangan pengambilan sampel audit internal di sini adalah untuk mengekstraksi sampel item yang akan mewakili seluruh populasi.

Diakui bahwa pembatasan akses dan perjalanan serta terbatasnya ketersediaan personel karena pertimbangan kesehatan dapat mengganggu kemampuan auditor internal untuk mendapatkan bukti audit yang cukup dan tepat.

\section{Solusi}

Kesimpulan audit hanya dapat dianggap benar jika sampel yang diambil mewakili seluruh populasi. Teknik pengambilan sampel audit dapat membantu auditor internal menentukan ukuran sampel yang sesuai dan mengembangkan pendapat untuk jenis tugas audit ini.

Auditor disarankan untuk mengeksplorasi prosedur alternatif, termasuk teknologi, sejauh mungkin. Penyelesaian audit yang berkualitas tinggi dalam kondisi saat ini memerlukan waktu tambahan, yang dapat memengaruhi tenggat waktu pelaporan. Sebagai konsekuensinya, auditor perlu menunda penerbitan laporan auditnya, dan jika hal ini tidak dapat untuk menyelesaikan hal tersebut, auditor perlu memodifikasi laporan auditnya untuk mencerminkan bahwa auditor belum dapat memperoleh bukti audit yang diperlukan. Auditor perlu berkomunikasi secara 
seksama dengan pihak manajemen dan pihak yang bertanggung jawab atas tata kelola dalam menentukan hal ini.

\section{Pertanyaan untuk didiskusikan}

1. Jelaskan alasan-alasan berikut ini mendorong penggunaan sampling audit dan sampling statistik!

2. Jelaskan empat metode umum untuk memilih sampel audit!

3. Pendekatan pengambilan sampel audit tergantung pada tujuan audit, apakah untuk tes kepatuhan, pengendalian laporan keuangan, atau pada kondisi khusus apa pun yaitu pendekatan sampel atribut, sampel variabel dan sampel penemuan.

4. Jelaskan kaitan antara jumlah sampel dengan identifikasi tingkat risiko!

5. Apa yang anda pahami tentang sampel atribut dan sampel unit moneter?

\section{Soal Kasus}

ABC. Inc memiliki sekitar 4.125 karyawan, dan audit internal memutuskan melakukan uji atribut untuk menilai pengendalian internal yang mencakup catatan sumber daya manusia. Fungsi sumber daya manusia $A B C$. Inc menggunakan dua sistem TI untuk perhitungan gaji dan dan memelihara sistem berbasis spreadsheet desktop mencatat asuransi kesehatan karyawan. Melalui peninjauan proses pencatatan sumber daya manusia, audit internal menemukan sekitar 30 masalah pengendalian pencatatan yang berbeda, seperti gaji ditahan untuk tujuan pajak hingga item-item kecil seperti pemotongan bulanan untuk membayar kontribusi serikat kredit karyawan benar.

Strategi audit adalah untuk menguji catatan sumber daya manusia $A B C$. Inc untuk atribut yang terpisah. Meskipun audit internal dapat menguji secara terpisah untuk 30 temuan, pendekatan yang lebih baik adalah memutuskan mana yang paling signifikan 
dan menguji hanya untuk atribut-atribut yang terpisah tersebut. Asumsikan bahwa audit internal telah memutuskan untuk menguji catatan sumber daya manusia untuk lima atribut berikut:

1. Nilai bayar dan status pada sistem otomatis harus sama dengan dalam file manual.

2. Otorisasi untuk pemotongan harus ditandatangani dan diberi tanggal.

3. Pemeriksaan latar belakang pra kerja seharusnya sudah selesai.

4. Jika tidak ada pengurangan asuransi jiwa, keringanan yang ditandatangani karyawan harus dicatat.

5. Kenaikan gaji sesuai dengan pedoman dan diotorisasi dengan baik.

Saudara sebagai auditor internal telah menentukan untuk menguji secara statistik pengendalian internal berdasarkan lima atribut Jelaskan bagaimana saudara menetapkan parameter pengambilan sampel dan mengembangkan rencana sampel.

\section{Daftar Pustaka}

Moeller, R. R. (2016). Brink's Modern Internal Auditing Eighth Edition A Common Body of Knowledge Published by John Wiley \& Sons, Inc., Hoboken, New Jersey.

Fraud Examiner Manual. (2012). Pengumpulan dan evaluasi bukti.

http://yukbelajaraudit.blogspot.com/. (2014). SAMPLING AUDIT.

Retrieved from http://yukbelajaraudit.blogspot.com /2014/08/sampling-audit.html

Jusup, A. H. (2001). Sampling Audit dalam Konsep Dasar. 1-33

Sarbanes. (2010b). Sarbanes-Oxley Act (SOx) Bagian 404. 


\section{BAB 9}

\section{KOMPETENSI UTAMA AUDITOR INTERNAL}

\section{Capaian Pembelajaran}

1. Mahasiswa mampu mengelola audit internal universe

2. Mahasiswa mampu memahami kompetensi kunci auditor internal.

3. Mahasiswa mampu memahami manajemen risiko.

4. Mahasiswa mampu memahami keterampilan wawancara.

\section{A. Pendahuluan}

Bagaimana sebuah kondisi jika internal audit hanya berenang di permukaan air yang tenang dan tidak mau menyelupkan kepalanya masuk sedikit saja di bawah permukaan air. Jika dalam kondisi air tenang saja tidak mau menyelam, apalagi jika ada gelombang di atas permukaan air. Kondisi dimana internal auditornya sudah memiliki kompetensi yang baik, sehingga bisa mengidentifikasi kualitas pengendalian internal dan menganalisis potensi risiko serta memberikan rekomendasi lebih awal. Namun, manajemen tidak mengikuti dan tidak segera menindaklanjuti rekomendasi tersebut. Dan, akhirnya, kejadian dan risk berubah menjadi loss.

Sudah menjadi alami bahwa tak ada yang sempurna. Namun, tak boleh pula ini menjadi alasan untuk tidak melakukan fungsi dengan baik, teliti dan profesional sesuai perannya. Jika anda mengetahui sesuatu secara detail, maka anda belum tentu ahli untuk mengkomunikasikannya. Anda perlu paham situasi dan kondisi serta memiliki rerangka berfikir agar bisa mengkomunikasikannya dengan baik. Memahami perspektif stakeholders adalah sangat penting agar fokus pada ide improvement dan shared values.Pemahaman terhadap proses bisnis, risk dan pengendalian sangat menentukan agar bisa mengkomunikasikan pesan-pesan secara efektif kepada 
stakeholders sesuai levelnya. Anggapan bahwa level teknis bukan urusan adalah alasan dari ketidaksiapan karena audit tidak menyentuh testing dan analisis secara detail untuk hal-hal yang strategis

Kompetensi inti yang diperlukan untuk menghasilkan wawasan adalah kemampuan untuk mengidentifikasi kebutuhan akan analisis akar permasalahan. Kompetensi ini akan bisa membantu unit operasional bisnis dalam meningkatkan hasil dan mencegah temuan berulang yang bisa menimbulkan inefisensi, ketidakpatuhan atau ketidakakurasian atau bahkan risiko yang lebih besar

\section{B. Mengelola Audit Internal Universe}

Hasil pemahaman atas klien, aktivitas dan manajemen risiko perlu dipetakan dalam audit universe yang memuat auditable units untuk tahun berikutnya. Dari audit universe, auditor intern akan menyusun Rencana Audit Intern Tahunan yang berisi auditable units berdasarkan prioritas yang dilakukan pada tahapan-tahapan berikutnya (Asosiasi Auditor Intern Pemerintah Indonesia, 2010) .

Penyusunan audit universe memudahkan auditor intern untuk mengorganisasikan kegiatan perencanaan audit tahunan dengan mengurangi kemungkinan terlewatnya aspek penting yang berpotensi menghasilkan rangkaian penugasan yang tidak efektif. Selain itu, penyusunan audit universe dapat mengurangi terjadinya pengulangan atau tumpang tindih yang berpotensi menghasilkan rangkaian penugasan yang tidak efisien.

\section{Muatan Audit universe}

Audit universe merupakan daftar yang secara sistematis menggambarkan klien dengan segala aktivitas, risiko, dan berbagai atribut lain yang diperlukan. Informasi yang terdapat dalam audit universe dapat mengarahkan auditor untuk 
memprioritaskan penugasannya. Oleh karena itu, akan sangat membantu jika audit universe dapat secara tegas menunjukkan terdapatnya peluang peningkatan pengendalian.

Kesan tentang pentingnya unit kerja atau kegiatan dalam audit universe untuk diprioritaskan dalam penugasan audit intern juga dapat diperoleh dari data lain misalnya ukuran atau besaran organisasi, jumlah anggaran, tingkat komputerisasi, jenis kegiatan yang dilaksanakan. Sepanjang tidak menambah kerumitan, informasi demikian dapat ditambahkan pada audit universe.

\section{Pendekatan Penyusunan Audit Universe}

Pendekatan ini tergantung dari struktur organisasi dalam menetapkan kegiatannya. Agar fungsi pengawasannya sejalan, auditor intern perlu menyelaraskan pendekatan penyusunan audit universe dengan pendekatan penyusunan kegiatan area yang diaudit. Audit universe dapat dikembangkan dengan menggunakan pendekatan yang mungkin berbeda berdasarkan muatan yang dikehendaki oleh auditor intern serta cara area yang diaudit mengorganisasi kegiatannya. Pendekatan yang dapat dipakai dalam penyusunan audit universe kegiatan diantaranya;

a. Pendekatan struktur organisasi. Dapat diterapkan pada area yang di audit yang memiliki sangat sedikit kebutuhan koordinasi dengan unit lain.

b. Pendekatan program. Diterapkan pada area yang diaudit yang dirancang dengan cakupan luas yang membutuhkan koordinasi beberapa unit yang berbeda. 
c. Pendekatan proses bisnis. Dapat diterapkan pada semua area yang di audit untuk memastikan rantai aktivitas perusahaan berungsi sesuai yang ditetapkan dan meningkatkan menilai tambah output.

\section{Penetapan Area Audit}

Besaran serta luasnya ruang lingkup kegiatan perusahaan multinasional mendorong terciptanya struktur orgainsasi tingkat tinggi. Secara vertikal, aktivitas perusahaan mengalir melalui organisasi tingkat pusat. Secara horizontal, kegiatankegiatan dicloning agar tercipta konsistensi dan keseragaman di antara organisasi yang selevel namun berbeda dalam lokasi atau fungsi.

Selaras dengan perencanaan dan pelaksanaan kegiatan yang bertingkat, pengawasan kegiatan pun disusun dengan cara yang bertingkat pula. Penugasan pengawasan harus diatur untuk mewujudkan efektivitas hasil penugasan dan efisiensi biaya penugasan. Selain itu, terjadinya tumpang tindih pengawasan atau terdapat bagian program atau kegiatan penting yang terlewat tanpa adanya pengawasan internal yang menanganinya harus dicegah.

Auditor internal harus dapat mengidentifikasi manajemen yang dilayaninya beserta kepentingannya karena pengguna hasil penugasannya adalah internal manajemen. Pemahaman hal ini akan memberikan auditor internal kompetensi yang cukup untuk menetapkan area audit dengan tepat. Penetapan area audit terkait langsung dengan ruang lingkup penugasan. Ruang lingkup yang tepat mengarahkan auditor internal untuk fokus pada unit operasional tertentu di mana informasi harus dikumpulkan. 
Menggunakan konsep audit universe terkadang dapat menimbulkan masalah jika ada terlalu banyak perubahan tingkat tinggi di perusahaan, seperti akuisisi atau disposisi organisasi. Untuk lebih memahami banyak bidang audit internal spesial (khusus) yang termasuk dalam audit universe, semua auditor internal harus memiliki beberapa kompetensi profesional utama, termasuk kemampuan untuk melakukan wawancara audit yang efektif dan kredibel ketika melakukan audit internal. Banyak bidang kompetensi utama mencakup hal-hal yang harus dipelajari dengan baik oleh auditor internal sebelum memulai karier dan bahkan selama bertahun-tahun memperoleh pendidikan dasar.

\section{Jadwal Audit Universe}

Fungsi audit internal perusahaan dapat mengalami masalah jika tidak memiliki prosedur perencanaan yang memadai yang didukung oleh jadwal audit universe (IIA, 2018).Jadwal audit universe harus mencantumkan entitas dalam rencana dan tinjauannya. Jika perusahaan begitu fleksibel sehingga semuanya terus berubah, mungkin ada beberapa kebutuhan untuk memikirkan kembali keseluruhan strategi audit internal.

Fungsi audit internal perusahaan harus mengembangkan jadwal audit universe yang ditinjau dan disetujui oleh komite audit dan manajemen senior. Audit universe mungkin tidak mencakup setiap unit dalam perusahaan, karena unit terlalu kecil, unit berisiko rendah, atau terlalu rumit secara teknis.

Namun, begitu fungsi audit internal telah menetapkan ruang lingkup bidang potensial untuk ditinjau, maka harus dilaksanakan dengan efektif dan efisien. 


\begin{tabular}{|c|c|c|c|c|c|c|c|c|}
\hline $\mathrm{N}$ & Area Audit & Tot & \multicolumn{2}{|c|}{2020} & \multicolumn{2}{|c|}{2021} & \multicolumn{2}{|c|}{2022} \\
\hline 1 & $\begin{array}{l}\text { Prosedur pengiriman } \\
\text { barang }\end{array}$ & 42 & $x$ & $x$ & $x$ & $x$ & $x$ & $x$ \\
\hline 2 & $\begin{array}{l}\text { Prosedur ceklist kualitas } \\
\text { produk }\end{array}$ & 35 & $x$ & & & $x$ & & $x$ \\
\hline 3 & $\begin{array}{l}\text { Prosedur perekrutan } \\
\text { karyawan }\end{array}$ & 30 & & $x$ & & $x$ & & $x$ \\
\hline 4 & $\begin{array}{l}\text { Prosedur penerimaan } \\
\text { bahan baku }\end{array}$ & 25 & & & & & & \\
\hline 5 & $\begin{array}{l}\text { Pelatihan penguatan } \\
\text { pelayanan pelanggan }\end{array}$ & 25 & $x$ & & $x$ & & $x$ & \\
\hline 6 & Prosedur penggajian & 24 & & $x$ & & & & \\
\hline 7 & $\begin{array}{l}\text { Sosialisasi etika dan } \\
\text { pedoman perilaku }\end{array}$ & 23 & & $x$ & & $x$ & & $x$ \\
\hline 8 & $\begin{array}{l}\text { Proses bisnis permintaan } \\
\text { bahan baku }\end{array}$ & 20 & & $x$ & & & & \\
\hline
\end{tabular}

Gambar 9.1. Jadwal Audit Internal Berbasis Risiko pada Anak Perusahaan B

Sumber : (Asosiasi Auditor Intern Pemerintah Indonesia, 2018)

Auditor internal harus menilai audit universe dan meninjau rencana audit tahunan dengan komite audit. Auditor kepala dan anggota lain dari tim manajemen audit internal harus bertanggung jawab atas perubahan jadwal, dan setiap pembaruan harus diberikan kepada komite audit.

D. Manajemen Risiko

Manajemen risiko bukanlah keterampilan audit internal yang diakui secara umum di hari-hari sebelumnya sampai tahun 1982. Namun, manajemen risiko saat ini merupakan persyaratan 
kompetensi utama auditor internal yang penting. Manajemen risiko harus dianggap sebagai proses empat langkah:

a. identifikasi risiko,

b. penilaian kuantitatif atau kualitatif dari risiko yang terdokumentasi,

c. prioritas risiko dan perencanaan respons, dan

d. pemantauan risiko.

Proses ini harus dilaksanakan di semua tingkatan perusahaan dan sebagai bagian dari hampir semua tinjauan audit internal. Risiko umum ini dapat terjadi karena berbagai keadaan mulai dari keputusan keuangan yang buruk, perubahan selera konsumen hingga peraturan pemerintah yang baru.

Apakah perusahaan itu kecil atau perusahaan global ia harus mengembangkan pendekatan manajemen risiko internal. Perusahaan global biasanya memiliki banyak unit yang terlibat dalam operasi dan fasilitas bisnis di berbagai negara. Beberapa risiko dalam satu unit dapat secara langsung berdampak atau terkait dengan risiko di unit lain, tetapi mungkin ada risiko tidak berdampak pada unit lainnya. Auditor internal harus berusaha untuk mengidentifikasi dan memahami berbagai risiko yang dihadapi suatu perusahaan dan menilai probabilitas dan dampak risiko terhadap finansial. Hal itu dilakukan untuk mengembangkan tanggapan jika terjadi risiko, dan untuk mengembangkan prosedur dokumentasi untuk menggambarkan apa yang terjadi serta tindakan korektif yang tepat di masa depan.

Sekarang ini risiko ada dimana-mana dan oleh karena itu, pemahaman yang baik tentang risiko akan membuat auditor internal mampu bersikap serta memitigasi risiko dengan baik. Oleh karena risiko itu adalah masalah prediksi ke waktu yang akan 
datang, maka perlu aspek logis dalam memberikan ukuran terjadinya suatu risk event. Artinya adalah auditor internal tidak boleh mendramatisasi risiko yang merupakan sebuah pola yang merusak pertumbuhan bisnis

Memang pelaku bisnis selalu menggunakan fakta lapangan dan data historis yang terukur ditambah sense yang kuat karena mereka "on the field" jadi mereka juga sangat paham bagaimana cara keluar dari risiko.

\section{E. Kompetensi Kunci Auditor Internal}

Ketika auditor internal dikirim ke beberapa lokasi audite untuk melakukan tinjauan, auditor internal harus mempertahankan sikap profesional dan melakukan pekerjaannya secara jujur dan etis.

Kompetensi utama audit internal merupakan keterampilan yang diperlukan untuk melakukan audit internal yang efektif. Kompetensi utama audit internal meliputi:

1. Keterampilan wawancara.

2. Keterampilan analitis.

3. Keterampilan menguji dan menganalisis.

4. Keterampilan mendokumentasikan.

5. Merekomendasikan hasil dan tindakan korektif.

6. Keterampilan berkomunikasi.

7. Keterampilan bernegosiasi.

8. Komitmen untuk belajar.

Poin-poin yang tercantum ini mewakili beberapa kompetensi dan keterampilan yang benar-benar penting dan diperlukan untuk melakukan audit internal yang efektif, apa pun jenis industrinya, letak area geografis, atau jenis audit internal yang dilakukan. 


\section{F. Keterampilan Wawancara}

Wawancara auditor internal dengan anggota manajemen audite merupakan langkah pertama yang penting dalam proses audit internal. Berdasarkan audit universe yang telah ditetapkan fungsi audit internal akan merencanakan untuk melakukan tinjauan terhadap beberapa area, penilaian pengendalian internal, review pengendalian operasional. Fungsi audit internal akan menyusun beberapa rencana awal untuk tinjauan termasuk mengidentifikasi tujuan audit, waktu, dan sumber daya audit internal yang ditugaskan. Selanjutnya auditor internal bertemu dengan anggota organisasi audite yang ditunjuk untuk wawancara audit internal awal.

Setelah auditor internal menjadwalkan wawancara dengan audite, auditor harus mulai fokus pada persiapan wawancara. Auditor internal tidak boleh berpikir bahwa ia dapat dengan mudah memasuki wawancara dengan audite dan hanya memberi tahu mereka tentang audit yang direncanakan.

Terkadang wawancara saat pemeriksaan auditor akan bertemu dengan banyak tipe orang dan bahkan bertemu dengan orang-orang yang sudah lelah dengan segala jenis pekerjaan dan "tekanan" target. Tentu kondisi ini membutuhkan banyak teknik wawancara berhubungan dengan banyak orang.

\section{G. Keterampilan Analisis dan Pengujian}

Keterampilan analitis mengacu pada kemampuan untuk memvisualisasikan, mengartikulasikan, dan memecahkan masalah dan konsep yang kompleks, dan sampai pada keputusan yang masuk akal berdasarkan informasi yang tersedia. Keterampilan tersebut meliputi kemampuan untuk menerapkan pemikiran logis untuk mengumpulkan dan menganalisis informasi, 
merancang dan menguji solusi untuk masalah, dan merumuskan rencana. Untuk menguji keterampilan analitis, auditor internal mungkin diminta untuk mencari ketidakkonsistenan dalam beberapa laporan produksi, untuk menempatkan serangkaian peristiwa dalam urutan yang tepat, atau untuk membaca secara kritis laporan status proyek dan mengidentifikasi potensi kesalahan. Tinjauan analitik biasanya auditor internal meninjau beberapa bahan bukti audit dan kemudian menggunakan logika untuk menyelesaikan masalah dan menghasilkan solusi.

Auditor internal diharapkan menggunakan proses analitis secara teratur untuk memecah unsur-unsur data apa pun atau serangkaian peristiwa yang dianalisis untuk mencapai kesimpulan. Agar benar-benar analitis, auditor internal perlu memikirkan semua faktor yang terlibat dalam suatu situasi dan kemudian mengevaluasi plus dan minusnya untuk mengembangkan solusi yang direkomendasikan.

Ada sejumlah besar alat analitis, beberapa sederhana dan lainnya sangat kompleks, yang dapat digunakan oleh auditor internal untuk mendukung tinjauan pengendalian internal. Pada tingkat yang sangat dasar, auditor internal dapat memeriksa apakah beberapa akun disetujui atau tidak disetujui atau akun benar atau tidak seimbang. Keterampilan analitis auditor berasal dari akumulasi hasil ini dan melaporkannya dalam hal ukuran statistik.

Keahlian analitis auditor internal adalah kompetensi utama yang dapat membantu keputusan audit internal untuk dikembangkan secara konsisten dan terorganisir. Terlalu sering, beberapa profesional menganggap istilah analisis terkait dengan proses terperinci dan berorientasi matematis. Auditor internal 
harus menggunakan analisis untuk menggambarkan penggunaan pendekatan keputusan yang terdokumentasi dengan baik.

Sementara auditor internal harus menggunakan pendekatan analitis untuk mengembangkan strategi keputusan awal dengan mengembangkan tes untuk meninjau dan menilai materi. Sebagai kompetensi utama auditor internal, pengujian atau pengambilan sampel dapat dilihat dalam perspektif yang lebih luas.

Persyaratan lain untuk kompetensi auditor internal adalah analisis yang tepat dari hasil pengujian. Setelah auditor internal memilih sampel dan melakukan tes, hasilnya harus dianalisis. Setelah menarik sampel yang sesuai dengan tujuan audit, auditor internal kemudian harus meninjau hasil sampel untuk setiap kemungkinan kesalahan untuk menentukan sifat dan penyebab kesalahan. Sampel yang dinilai sebagai kesalahan, maka kesalahan yang ditemukan harus diproyeksikan sebagaimana mestinya ke populasi item. Auditor internal harus mempertimbangkan aspek kualitatif kesalahan, termasuk sifat dan penyebab kesalahan dan kemungkinan dampak kesalahan pada fase audit lainnya. Auditor internal juga harus menyadari bahwa kesalahan yang merupakan hasil dari gangguan proses $\mathrm{TI}$ biasanya memiliki implikasi yang lebih luas daripada kesalahan manusia.

Setiap upaya harus difokuskan untuk memastikan bahwa hasil tes mewakili populasi keseluruhan item yang ditinjau. Ketika hasil audit ada indikasi tidak benar, auditor internal harus melakukan prosedur tindak lanjut yang diperlukan.

\section{H. Keterampilan Komunikasi}

Auditor harus tetap konsisten untuk menyempatkan diri berkomunikasi dengan audite saat melakukan atau setelah selasai melakukan review. Komunikasi itu bisa dalam bentuk wawancara 
singkat untuk memastikan proses bisa berupa diskusi singkat untuk menyampaikan simpulan pemeriksaan. Poin-poin hasil wawancara dituliskan di kertas kerja, karena bagian dari proses penjaminan, dimana audite telah mempekerjakan orang-orang yang paham atas risiko produk yang dijualnya.

Auditor internal dalam melaksanakan audit perlu paham situasi dan kondisi serta memiliki rerangka berfikir agar bisa mengkomunikasikannya dengan baik. Disamping hal tersebut, auditor internal harus memahami values dari perannya agar bisa menyampaikan idenya dengan baik. Apa yang dipikirkan, pasti itulah yang akan dikomunikasikan. Tergantung values apa yang ada dibenak serta sejauh apa kemampuan berfikir seseorang untuk menggali yang dalam atas ide perbaikan dari hasil-hasil auditnya. Memahami perspektif stakeholders adalah sangat penting agar fokus pada ide perbaikan dan berbagi nilai . Pemahaman terhadap proses bisnis, risiko dan pengendalian internal sangat menentukan agar bisa mengkomunikasikan pesanpesan secara efektif kepada stakeholders sesuai levelnya.

\section{Keterampilan Dokumentasi}

Auditor internal memiliki tantangan besar untuk menyiapkan dokumentasi yang bermakna dan bermanfaat yang mencakup semua pekerjaan mereka, baik catatan informal dari rapat hingga kertas kerja audit atau laporan audit akhir yang dikeluarkan. Auditor internal memiliki kebutuhan berkelanjutan untuk mengembangkan keterampilan dokumentasi kerja audit yang kuat. Fungsi audit internal harus menetapkan beberapa standar praktik terbaik untuk dokumentasi elektronik internalnya. Dalam beberapa kasus, perangkat lunak otomasi membuat pendokumentasian menjadi mudah. 
Semua auditor internal harus mengembangkan keterampilan dan kompetensi yang kuat dalam mendokumentasikan setiap aspek pekerjaan mereka. Auditor internal harus selalu mengingat bahwa dokumentasinya, di semua tingkatan, dapat dikenakan ulasan atau pengungkapan lainnya. Apakah itu permintaan dari anggota komite audit, audit eksternal, perintah pengadilan, atau bahkan tindakan pemerintah, dokumentasi yang tidak disiapkan dengan akurat dapat mempermalukan atau bahkan membahayakan perusahaan dan merusak baik fungsi audit internal maupun auditor internal

\section{J. Hasil yang Direkomendasikan dan Tindakan Korektif}

Peran yang sangat kuat mungkin yang paling penting dari auditor internal adalah melaporkan hasil audit dan mengembangkan rekomendasi yang kuat untuk tindakan korektif yang sesuai. Dalam semua kasus, auditor internal perlu memiliki keterampilan utama untuk merangkum hasil beberapa pekerjaan audit, untuk membahas apa yang salah, dan untuk mengembangkan beberapa rekomendasi untuk tindakan korektif yang efektif. Sehingga mereka harus membangun kompetensi untuk menggambarkan temuan audit dan membuat rekomendasi untuk perbaikan.

Auditor internal di semua tingkatan harus mengembangkan kompetensi untuk merekomendasikan sebagian besar pekerjaan mereka. Auditor internal dapat menjawab pertanyaanpertanyaan dengan istilah yang cukup jelas dan sederhana sehingga penerima dapat memahami masalah dan sifat tindakan korektif yang disarankan. Konsep ini dapat menjadi sangat sulit jika temuan audit mencakup area yang kompleks atau berpotensi tidak jelas. Sebagai contoh, sebuah temuan audit yang mencakup 
kelemahan pengendalian internal yang disebabkan oleh pengaturan yang salah dalam sistem operasi $\mathrm{TI}$ yang sulit dipahami oleh banyak orang. Namun, dengan menggunakan analogi atau mekanisme lain, auditor internal harus berusaha untuk menyiapkan temuan dan rekomendasi dengan cara yang mudah dipahami. Penyusunan laporan audit internal yang efektif, dengan temuan dan rekomendasi yang bermakna, adalah bidang kompetensi yang sangat penting bagi semua auditor internal.

\section{K. Keterampilan Negosiasi}

Negosiasi biasanya dianggap sebagai kompromi untuk menyelesaikan argumen atau masalah demi kepentingan auditor internal dan pihak lain. Rekomendasi yang dikembangkan dalam laporan audit atau yang dikembangkan dalam proses peninjauan bukti audit, auditor internal akan menghadapi banyak bidang di mana manajemen dan pihak lain akan tidak setuju dengan asumsi auditor.

Komunikasi selalu merupakan tautan yang harus digunakan oleh auditor internal untuk merundingkan masalah atau argumen, apakah itu dilakukan secara tatap muka, di telepon, atau secara tertulis. Namun, auditor internal pada semua tingkatan harus mengakui negosiasi tidak selalu antara dua orang; dapat melibatkan auditor internal dengan banyak anggota dari kelompok yang diaudit.

Auditor internal di semua tingkatan harus belajar keterampilan negosiasi ketika menyelesaikan laporan audit dan menyiapkan rekomendasi. Selalu ada masalah di sini, tetapi auditor internal harus mengakui bahwa semua jenis temuan audit, akan dipandang sebagai kritik oleh manajemen audite. Kadang-kadang auditor internal akan menghadapi situasi di mana 
manajemen yang diaudit ingin melawan audit internal pada setiap titik, tidak peduli seberapa sepele atau seberapa solid temuan audit.

Auditor internal harus mengembangkan keterampilan untuk bernegosiasi dan berkompromi pada beberapa bidang, tetapi harus selalu konsisten untuk mengatakan bahwa ada sesuatu yang salah dan perlu dilaporkan; setiap perselisihan dengan audite dapat dicatat dalam tanggapan terhadap laporan audit dan interaksi dengan komite audit.

\section{Komitmen Auditor Internal Untuk Belajar}

Kompetensi kunci auditor internal yang sangat signifikan adalah bahwa semua auditor internal harus mengembangkan komitmen yang kuat untuk belajar. Karena bisnis dan teknologi selalu berubah, seperti juga iklim politik dan peraturan di mana perusahaan beroperasi. Semua auditor internal harus merangkul komitmen untuk pembelajaran yang konstan dan berkelanjutan sebagai kompetensi yang sangat utama. Stagnasi nilai akan terjadi jika seseorang mengaku professional tapi berhenti belajar dan berpuas diri termasuk setelah apa yang diinginkannya sudah diraih. Auditor internal harus senantiasa belajar dan mengemban tanggung jawab moralnya untuk mengembangkan diri dan teguh kepada professionalisme. Selalu fokus memberi nilai kepada stakeholders dan melakukan role sesuai nilai-nilai yang ada pada practice standard.

\section{Simpulan}

Audit universe dapat dikembangkan dengan menggunakan pendekatan yang mungkin berbeda berdasarkan muatan yang dikehendaki oleh auditor intern serta cara area yang diaudit mengorganisasi kegiatannya. Auditor internal harus dapat 
mengidentifikasi manajemen yang dilayaninya beserta kepentingannya karena pengguna hasil penugasannya adalah internal manajemen. Pemahaman hal ini akan memberikan auditor internal kompetensi yang cukup untuk menetapkan area auditnya dengan tepat

Audit universe adalah ruang lingkup entitas audit internal yang dapat diaudit untuk suatu perusahaan yang seharusnya dimasukkan dalam rencana audit tahunan. Auditor internal harus menilai audit universe dan meninjau rencana audit tahunan.

Seorang auditor internal harus memiliki etika pribadi yang kuat dan komitmen yang terkait dengan pekerjaan. Ketika auditor internal dikirim ke beberapa lokasi audite untuk melakukan tinjauan, auditor internal harus mempertahankan sikap profesional dan melakukan pekerjaannya secara jujur dan etis. Hal-hal ini mendasar dan perlu untuk membangun seperangkat kompetensi utama auditor internal. Auditor internal harus memiliki kompetensi utama audit internal merupakan keterampilan yang diperlukan untuk melakukan audit internal yang efektif.

N. Contoh Kasus mengelola audit internal universe dan kompetensi utama

Fungsi audit intern pada sebuah perusahaan sangat tergantung dari kompleksitas yang ada dalam perusahaan. Mengelola audit universe memerlukan pemahaman atas klien, aktivitas dan manajemen risikonya dan selanjutnya dipetakan dalam audit universe yang memuat auditable unit untuk tahun berikutnya.

Saat ini, dunia sedang mengalami revolusi industry ke-4, dimana banyak teknologi baru yang diperkenalkan yang mencampurkan berbagai aspek physical, digital, biological, dan berdampak pada seluruh disiplin ilmu, ekonomi dan juga industri; 
sebut saja artificial intelligence, robotics, nanotechnology, printer 3 dimensi, autonomous cars, drones, sudah menjadi bagian dari kehidupan manusia. Ini adalah "the new normal".

Tentunya profesi auditor internal tidak bisa hanya menggunakan pola pandang, pengetahuan dan cara-cara yang lama, karena menjadi tidak sejalan dengan perkembangan yang ada, dan mungkin menjadi tidak tepat lagi untuk diterapkan. Profesi auditor internal dituntut untuk bisa maju dengan cepat mengikuti perkembangan bisnis dan teknologi yang dinamis dengan tetap menjunjung nilai-nilai etis dan karaktestik auditor internal.

Seperti apa interaksi dan proses kerja fungsi audit internal, termasuk tekanan dan tantangan yang dihadapi.

Solusi

Persyaratan Auditor Intern sekurang-kurangnya meliputi:

1. Memiliki pengetahuan, keterampilan, dan kompetensi yang dibutuhkan dalam pelaksanaan fungsi audit intern secara menyeluruh baik secara individu maupun secara kolegial, sesuai dengan perkembangan kegiatan usaha dan kompleksitas Bank.

2. Menerapkan pengetahuan, keterampilan dan kompetensi yang dilaksanakan secara professional dan skeptis, mencakup untuk mengumpulkan dan memahami informasi, memeriksa dan mengevaluasi bukti audit serta melakukan komunikasi dengan pemangku kepentingan.

3. Meningkatkan pengetahuan, keterampilan dan kompetensi lain melalui pengembangan professional berkelanjutan, melalui upaya:

a. mengikuti perkembangan terakhir tentang teknik audit intern, standar akuntansi keuangan, perpajakan, dan 
teknologi informasi melalui seminar, kursus, atau pendidikan lanjutan lain.

b. Mengikuti perkembangan produk dan/atau aktivitas perusahaan;

c. Mengikuti perkembangan ketentuan yang berkaitan dengan kegiatan operasional perusahaan.

d. Memiliki pengetahuan dan/atau pemahaman tentang operasional perusahaan.

\section{Pertanyaan untuk didiskusikan}

1. Jelaskan cara untuk membuat jadwal audit universe!

2. Mengapa seorang auditor internal hasil memiliki kompetensi utama dan sebutkan jenis kompetensi utama tersebut!

3. Menejeman risiko merupakan keterampilan utama yang harus dimuliki seorang auditor internal. Jelaskan proses empat langkah dalam melakukan manajemen risiko!

\section{Soal Kasus}

Sudah banyak perguruan tinggi menerapkan sistem pembayaran secara host to host dengan bank persepsi melalui web. Namun belum ada regulasi yang mengatur mengenai pembayaran host to host untuk perguruan tinggi ketika terjadi ketidak sinkronan jumlah tagihan dibank dan tagihan diperguruan tinggi. Ini harus menjadi pemikiran internal audit dan melakukan evaluasi sehingga menjadi jelas bahwa peruruan tinggi sudah memikirkannya.

Jelaskan keterampilan yang diperlukan untuk melakukan evaluasi kasus diatas.!

\section{Daftar Pustaka}

Asosiasi Auditor Intern Pemerintah Indonesia. (2018). Pedoman Perencanaan Audit Berbasis Risiko Auditor Intern 
Pemerintah Indonesia.

Moeller, R. R. (2016). Brink's Modern Internal Auditing Eighth Edition A Common Body of Knowledge Published by John Wiley \& Sons, Inc., Hoboken, New Jersey.

https://jonnygultom.wordpress.com. (2016) .https://jonny gultom.wordpress.com/2016/03/19/failures/. 


\section{BAB 10}

\section{MERENCANAKAN AUDIT}

\section{Capaian Pembelajaran}

1. Mahasiswa mampu membuat perencanaan audit internal.

2. Mahasiswa mampu memahami lingkungan bisnis

3. Mahasiswa mampu memahami lingkungan pengendalian internal

4. Mahasiswa mampu membuat penilaian risiko

\section{A. Pendahuluan}

Meskipun komite audit, manajemen perusahaan senior, atau bahkan manajemen audit internal dapat meminta beberapa area atau fungsi harus diaudit, audit internal memerlukan rencana untuk melakukan tinjauan individu tersebut. Auditor internal harus berpikir melakukan audit internal sebagai suatu "proyek", yaitu membutuhkan upaya khusus yang memerlukan perencanaan, penganggaran, dan alokasi sumber daya, pelaksanaan, dan laporan audit.

Praktik terbaik manajemen proyek harus menjadi alat penting untuk perencanaan dan pelaksanaan semua tingkatan audit internal. Pendekatan audit internal berbasis proyek umumnya harus meningkatkan manajemen dan proses kinerja audit internal. Konsep manajemen proyek harus membantu merencanakan dan melakukan audit internal individual.

\section{B. Perencanaan Audit Internal}

Sesuai (IIARF, 2009) menyatakan auditor kepala harus menyusun perencanaan audit berbasis risiko untuk menetapkan prioritas kegiatan aktivitas audit internal sesuai dengan tujuan organisasi. Untuk membangun perencanaan audit internal berbasis risiko, auditor kepala konsultasi kepada manajemen senior dan 
dewan untuk memperoleh suatu pemahaman mengenai strategi organisasi, tujuan kegiatan kunci, risiko-risiko terkait, dan proses manajemen risiko. Auditor kepala harus mengkaji dan menyesuaikan perencanaan seperlunya untuk merespon perubahan dalam berbagai hal seperti: usaha, risiko, operasi, program, sistem, dan pengendalian organisasi.

Berdasarkan (IIARF, 2009) Perencanaan penugasan sebagai aktivitas audit internal harus didasarkan atas penilaian risiko yang terdokumentasikan, yang dilakukan sekurang-kurangnya setahun sekali. Masukan dari manajemen senior dan dewan harus diperhatikan dalam proses tersebut. Perencanaan audit tahunan terdiri dari;

a. pembuatan profil risiko,

b. kompilasi inventarisasi audit, serta

c. pembuatan rencana audit tahunan dan rencana pelaksanaan berbasis tim regional.

Pembuatan profil risiko dilakukan untuk semua entitas auditable. Untuk semua entitas tersebut dibuat profil risiko, dan selanjutnya ditambahkan ke inventaris audit. Selanjutnya rencana audit tahunan kemudian disusun berdasarkan topik dalam profil risiko dan inventaris audit masing-masing. Setiap profil risiko mencakup dua komponen penting dalam format matriks (Henning Kagermann, 2008).

Sebagai ilustrasi perencanaan audit berdasarkan struktur organisasi. Pada tahap identifikasi, penilaian dan pengukuran risiko auditor internal harus memastikan bahwa setiap unit kerja telah melakukan identifikasi risiko dan pengukuran risiko. Pada unit kerja telah ditentukan lima faktor risiko antara lain

a. efektivitas pengendalian internal

b. potensi terjadinya kecurangan 

c. sebaran kegiatan
d. pemangku kepentingan
e. pengelolaan jumlah anggaran

\begin{tabular}{|l|l|c|c|l|}
\hline Unit kerja & $\begin{array}{l}\text { Deskripsi } \\
\text { risiko }\end{array}$ & Dampak & $\begin{array}{l}\text { Kemungkinan } \\
\text { terjadinya }\end{array}$ & $\begin{array}{l}\text { Nilai } \\
\text { Risiko }\end{array}$ \\
\hline 1 & 2 & 3 & 4 & $5=3 \times 4$ \\
\hline Produksi & $\begin{array}{l}\text { Tersedianya } \\
\text { bahan baku }\end{array}$ & 3 & 5 & 15 \\
\hline Pemasaran & $\begin{array}{l}\text { Permintaan } \\
\text { turun }\end{array}$ & 4 & 4 & 16 \\
\hline Akuntansi & Piutang & 3 & 3 & 12 \\
\hline TI & Gangguan & 4 & 5 & 20 \\
\hline
\end{tabular}

Gambar ;10.1 penilaian risiko berdasarkan penilaian risiko

Untuk tujuan pemeringkatan area audit berdasarkan risiko diperlukan faktor risiko yang akan ditambahkan pada penilaian risiko. Ilustrasi besaran risiko area audit setelah mempertimbangan faktor risiko

\begin{tabular}{|l|l|l|l|l|l|l|l|}
\hline Unit kerja & $\begin{array}{l}\text { Nilai } \\
\text { risiko }\end{array}$ & \multicolumn{3}{|l|}{ Faktor risiko } & $\begin{array}{c}\text { Total } \\
\text { risiko }\end{array}$ \\
\hline & & 1 & 2 & 3 & 4 & 5 & \\
\hline Produksi & 15 & 3 & 2 & 4 & 3 & 4 & 31 \\
\hline Pemasaran & 16 & 4 & 3 & 4 & 2 & 3 & 32 \\
\hline Akuntansi & 12 & 4 & 3 & 2 & 2 & 2 & 25 \\
\hline TI & 20 & 4 & 4 & 3 & 3 & 4 & 39 \\
\hline
\end{tabular}

Gambar 10.2. Besaran risiko area audit

Dengan menggunakan pemeringkatan total risiko auditor internal dapat menentukan urutan prioritas unit kerja yang akan diaudit pada tahun yang akan datang. Struktur rencana audit tahunan mengikuti struktur tim audit. Hal ini untuk memastikan 
alokasi audit yang tepat sesuai dengan tanggung jawab tim. Setiap perikatan audit diurutkan sesuai dengan prioritas atau peringkat risiko potensial.

\begin{tabular}{|c|c|c|c|c|c|c|}
\hline \multicolumn{7}{|c|}{$\begin{array}{l}\text { Location: Muddville Plant Facility } \\
\text { Assigned Audit Team: }\end{array}$} \\
\hline \multirow{2}{*}{ No. } & \multirow{2}{*}{ Audit Activity } & \multicolumn{5}{|c|}{ Week } \\
\hline & & 1 & 2 & 3 & 4 & 5 \\
\hline 1 & $\begin{array}{l}\text { Tinjau aktivitas masa lalu dan nilai } \\
\text { risiko }\end{array}$ & $x$ & & & & \\
\hline 2 & $\begin{array}{l}\text { Kembangkan pendekatan dan } \\
\text { rencana audit }\end{array}$ & $x$ & & & & \\
\hline 3 & $\begin{array}{l}\text { Kontak lokasi untuk } \\
\text { menjadwalkan audit }\end{array}$ & $x$ & & & & \\
\hline 4 & Perjalanan & $x$ & & & $x$ & \\
\hline 5 & $\begin{array}{l}\text { Tinjau dan dokumentasikan } \\
\text { proses }\end{array}$ & & $x$ & & & \\
\hline 6 & $\begin{array}{l}\text { Lakukan walk-through untuk } \\
\text { menegaskan pemahaman }\end{array}$ & & $x$ & $x$ & & \\
\hline 7 & Lakukan tes kontrol internal & & $x$ & $x$ & & \\
\hline 8 & $\begin{array}{l}\text { Lakukan prosedur audit lainnya } \\
\text { rencana audit }\end{array}$ & & & $x$ & $x$ & \\
\hline 9 & Ringkas dan pastikan hasil audit & & & & $x$ & \\
\hline 10 & Kertas kerja audit lengkap & & & & $x$ & \\
\hline 11 & Jadwalkan rapat penutupan audit & & & & $x$ & \\
\hline 12 & $\begin{array}{l}\text { Menyiapkan draf laporan audit } \\
\text { untuk tindakan korektif }\end{array}$ & & & & & $x$ \\
\hline
\end{tabular}

Gambar 10.3 Rencana Audit Internal Pendahuluan untuk Program peningkatan kualitas bahan baku

Sumber : ( Moeller. R.R,2016) 
Setelah perencanaan audit tahunan selesai langkah selanjutnya adalah persiapan rencana pelaksanaan audit yang sebenarnya. Dua poin penting terkait pelaksanaan audit:

a. Penugasan audit harus sesuai dengan jumlah tim audit, keterampilan, kualifikasi, pengalaman, ketersediaan SDM.

b. Perencanaan waktu dan urutan audit.

Langkah pertama melihat laporan audit internal sebelumnya baik dalam proses atau rencana jangka pendek, untuk mempertimbangkan ketersediaan sumber daya dan kemudian menyiapkan rencana audit internal awal.

Karena informasi di sini hanya sangat awal, rencana tersebut tidak menggunakan tanggal tertentu tetapi mengasumsikan bahwa dua anggota staf audit internal akan ditugaskan untuk melakukan pekerjaan. Rencana awal yang ditampilkan hanya menggunakan perkiraan jam pada saat ini.

Langkah selanjutnya adalah memberi tahu manajemen yang bertanggung jawab melalui surat perikatan audit internal. Biasanya dilakukan bersama dengan beberapa diskusi pendahuluan tingkat tinggi, dalam diskusi tersebut membahas tentang surat perikatan dan memberitahu audit yang direncanakan bersama tujuannya, perkiraan tanggalnya, dan auditor internal yang ditugaskan.

\section{Memahami Lingkungan Bisnis}

Perusahaan besar dan maju selalu mengidentifikasi efisiensi proses bisnis melalui pemangkasan birokrasi yang tidak perlu, sehingga mereka mampu bergerak cepat merespon perubahan dan beban tambahan akibat market competition. Ini adalah situasi yang sangat kompleks dan harus menjadi concern bagi auditor internal yang memiliki resources dalam hal professional intimacy dengan unit dalam perusahaan. Auditor internal tidak akan mampu menyelesaikan masalah jika kemampuan berfikirnya masih pada 
level yang sama ketika masalah itu terjadi. Jadi, sebaiknya juga dicek dengan benar cara berfikir dengan mengevaluasi;

a. Pahami perubahan indurtsi dan eksternal. Tidak ada satu pun perusahaan yang dapat 'menghentikan' disrupsi digital atau mencegah beberapa model bisnis baru yang disukai oleh semua orang di dunia.

b. Pahami tujuan dan strategi bisnis. Memahami konsekuensi dari apapun pilihan tujuan dan strategis bisnis yang diambil untuk menyikapi kekuatan disrupsi.

c. Pahami operasi dan proses bisnis. Operasi dan proses bisnis harus menyertakan perkembangan teknologi.

d. Pahami manajemen dan tata kelola. Memahami peluang dan risiko bila perusahaan langsung merangkul disrupsi.

e. Pahami pengukuran kinerja.Pengukuran kinerja tentu harus diselaraskan dengan era derupsi bukan pengukuran kinerja yang konvensional.

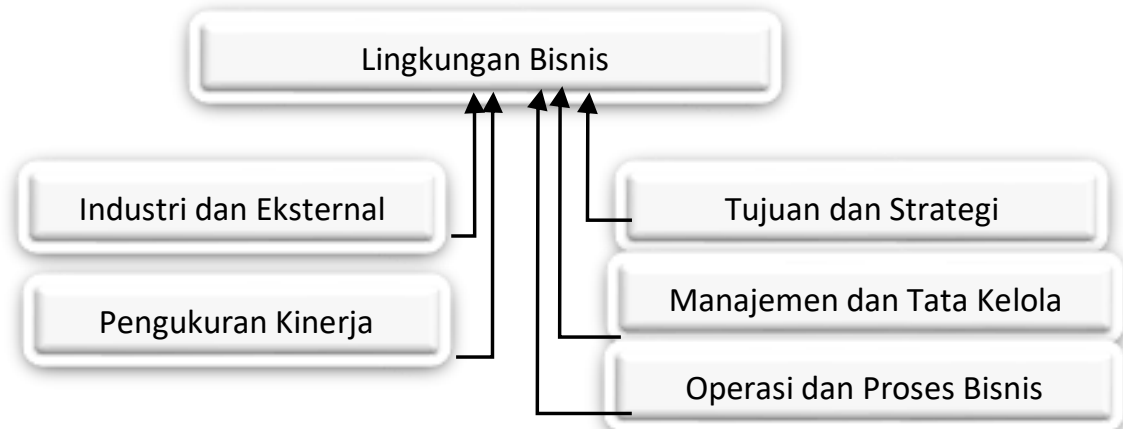

Gambar 10.4. Memahami Lingkungan Bisnis

Sumber : (Henning Kagermann, 2008)

\section{Memahami Tujuan dan Strategi Perusahaan}

Lingkungan bisnis terus berkembangan seiring dengan revolusi industri sekarang lingkungan bisnis berada pada revolusi industri 4.0. dari perkembangan teknologi menjadi perkembangan 
teknologi informasi. Perkembangan teknologi informasi yang sangat pesat dan intensif telah membawa perubahan dalam pola bisnis di segala jenis industri. Teknologi informasi sudah menjadi sesuatu yang harus diadopsi agar dapat memenuhi kebutuhan sebuah perusahaan untuk bisa eksis dalam kompetisi market. Karena audit internal berbasis risiko dan pengendalian internalnya menggunakan kerangka kerja COSO, maka pemahaman atas tujuan dan strategi diarahkan pada lingkungan pengendalian.

a. Pahami kultur risiko perusahaan melalui visi dan missi yang kemudian ditransformasikan melaui proses objective setting. Objective setting ini akan diklarifikasi dengan risk appetite dan juga risk framework serta bagaimana pengendaliannya operasionalnya

b. Pahami fungsi-fungsi yang ada siap untuk melakukan role dengan baik dan orang dalam perusahaan memiliki risk knowledge yang baik sehingga mereka mampu menyelaraskan perilaku yang berkinerja baik.

Risk Culture itu mengutamakan nilai, dan persepsi serta pemahaman mengenai nilai-nilai sangat menentukan bagaimana perusahaan merespon sebuah risiko melalui sebuah pengendalian. Sekarang ini risiko ada dimana-mana dan oleh karena itu, pemahaman yang baik akan membuat perusahaan mampu bersikap serta memitigasi risiko dengan baik (https://jonnygultom.wordpress.com, 2019).

\section{Memahami Operasi dan Proses Bisnis}

Bisnis digerakkan melalui berbagai tingkatan entitas pada berbagai tahap proses bisnis dan konteks teknologi yang digunakan. Dalam melakukan proses bisnis perusahaan harus mematuhi kebijakan dan prosedur dalam rangka rangka 
meminimalkan risiko atas pencapaian tujuan. Memahami operasi dan proses bisnis diantaranya;

a. Memahami pembagian tugas pada berbagai tingkat entitas

b. Memahami koordinasi pada berbagai tingkat entitas

c. Memahami kebijakan dan prosedur pada berbagai tingkat entitas

d. Memahami identifikasi risiko pada berbagai tingkat entitas

e. Memahami mitigasi risiko pada berbagai tingkat entitas

f. Mengunjungi pabrik dan kantor mengamati kegiatan operasi.

\section{Memahami Manajemen dan Tata Kelola}

Karena manajemen yang menciptakan strategi perusahaan dan proses bisnis, auditor harus menilai filosofis manajemen dan gaya kepemimpinan serta kemampuan untuk mengidentifikasi dan mitigasi risiko. Memahami manajemen dan tata kelola meliputi hal-hal sebagai berikut;

a. Pahami struktur organisasi dan aktivitas dewan direksi dan komite audit.

b. Pahami akta pendirian perusahaan dan peraturan - peraturan dalam perusahaan.

c. Pahami etika bisnis dan pedoman perilaku.

d. Pahami setiap notulen rapat untuk mendapatkan otoritas dan informasi lainnya yang relevan dengan pelaksanaan audit.

e. Pahami asas Transparency, Accountability, Responsibility, Independency, dan Fairness) dalam perusahaan.

\section{Memahami Pengukuran Kinerja}

Perusahaan harus memiliki pengukuran kinerja secara kuantitatif yang membantu manajemen memahami sesuatu yang penting dalam proses bisnis. Penggunaan alat bantu yang tepat dalam pengukuran kinerja akan dapat memudahkan dalam memahami, mengelola, dan meningkatkan hasil yang dicapai 
organisasi. Untuk memahami pengukuran kinerja auditor internal menelaah;

a. Visi, Misi dan tujuan perusahaan

b. Tahapan untuk mencapai visi perusahaan

c. Target yang ditetapkan perusahaan

d. Standar yang ditetapkan perusahaan.

Perusahaan dapat mengembangkan ukuran kinerja yang sesuai dengan kebutuhan dan tergantung pada visi, misi dan tujuan yang ingin dicapai. Secara umum ada enam kategori ukuran kinerja adalah:

a. Efektivitas. Karakterisitik proses yang mengindikasikan tingkat keluaran proses sesuai dengan persyaratan standar yang ditetapkan.

b. Efisiensi. Karakterisitk proses yang mengindikasikan proses berjalan dengan menggunakan sumber daya yang paling kecil untuk mencapai hasil yang diharapkan.

c. Kualitas. Proses bisnis telah memenuhi persyaratan kualitas dan sesuai harapan stakeholders.

d. Waktu. Ukuran dimana satuan aktivitas dijalankan dengan benar pada waktu yang telah ditentukan.

e. Produktivitas. Nilai tambah yang dihasilkan dari proses terhadap sumber daya yang digunakan.

f. Safety. Ukuran keseluruhan kesehatan organisasi dan lingkungan kerja bagi pelanggan, karyawan perusahaan.

Hal yang terjadi dalam era disrupsi antara lain:

a. Penghematan biaya bisnis secara fisik karena bisnisnya dilakukan pada dunia maya dan menjadi lebih simple

b. Menjadikan kualitas produk dari bisnis tertentu menjadi lebih baik dengan perkembangan yang pesat 
c. Era disrupsi menciptakan pasar baru sehingga bisnis yang selama ini tertutup dapat terbuka kembali

d. Produk atau layanan pada era disrupsi lebih mudah di akses dan dipilih seperti online shop dimana kita hanya membuka took melalui didunia maya lalu memesan serta mengaksesnya dari internet

e. Era disrupsi membuat segala hal sekarang menjadi serba smart. Lebih pintar, lebih menghemat waktu dan lebih akurat.

\section{Memahami Lingkungan Pengendalian Internal}

Risiko dan pengendalian internal yang diidentifikasi baik untuk proses secara keseluruhan atau untuk langkah-langkah proses tunggal adalah bagian penting dari program kerja. Dalam kerangka kerja COSO maupun kerangka kerja pengendalian internal lain yang diterapkan, ada dua titik awal yang memungkinkan untuk menganalisis risiko dan pengendalian internal:

a. Pertama, pahami jika perusahaan belum menerapkan hukum atau undang-undang. Perusahaan harus menentukan risiko audit berdasarkan risiko umum dan pengendalian internal untuk setiap langkah proses.

b. Kedua, sistem manajemen risiko dan pengendalian dapat dikembangkan dengan sangat baik sehingga untuk kegiatan kerja lapangan tertentu, dimungkinkan untuk merujuk dari program kerja ke dokumentasi sumber yang relevan dari sistem pengendalian internal.

\section{Pahami Kategori Risiko Utama dan sub-Risiko}

Selain risiko yang dapat dikendalikan terdapat risiko tak terduga harus dapat diidentifikasi setiap saat selama kerja lapangan. Risiko tak terduga harus didokumentasikan dalam 
kertas kerja tetapi tidak boleh mempengaruhi alokasi risiko dalam program kerja.

\section{a. Pahami Signifikansi Pengendalian internal}

Berbagai jenis pengendalian internal dapat digunakan secara khusus untuk mengurangi risiko. Pengendalian internal yang terkandung dalam lingkup dapat digunakan sebagaimana adanya saat membuat program kerja, atau disesuaikan dengan audit individu. Namun, jika dokumentasi hukum SOX tersedia, pengendalian yang sudah ditentukan harus dianggap wajib. Selain itu, definisi pengendalian dapat bervariasi antara lingkup dan program kerja karena praktik bisnis regional atau undang-undang dan peraturan yang berbeda.

Kombinasi penggunaan langsung dan adaptasi pengendalian internal yang terkandung dalam lingkup di atas adalah fondasi yang baik untuk pembuatan catatan lengkap semua pengendalian internal dalam program kerja. ini dimaksudkan untuk memastikan bahwa semua proses bisnis yang signifikan termasuk pengendalian internal masingmasing unit sepenuhnya dicakup. Selain itu, prosedur audit berdasarkan dokumentasi proses yang sesuai dengan SOX memberikan dasar penting untuk langkah memahami pengendalian internal.

\section{b. Pahami Risiko Audit}

Gambar 10.5 menunjukkan bahwa risiko audit memiliki dua komponen, risiko kesalahan dan risiko deteksi. Risiko kesalahan terurai lebih jauh menjadi risiko yang melekat dan mengendalikan risiko.

Risiko inheren adalah risiko yang intrinsik untuk suatu proses dan hasil dari kerentanan objek audit terhadap 
kesalahan. Risiko inheren dapat dipicu oleh faktor ekonomi makro, faktor spesifik sektor dan perusahaan (mis., Situasi ekonomi, struktur organisasi, atau lingkungan hukum perusahaan, serta faktor khusus untuk objek audit).

Pemicu risiko inheren untuk objek audit termasuk kompleksitas proses kerja di unit bisnis dan departemen dan tekanan waktu yang menjadi sasarannya. Untuk menilai risiko yang melekat, auditor harus memiliki pengetahuan yang komprehensif tentang perusahaan dan lingkungannya dan menggunakan wawancara dan observasi atau menganalisis dokumen untuk mendapatkan informasi tentang beban kerja, kualitas kerja, dan teknik di unit yang diaudit.

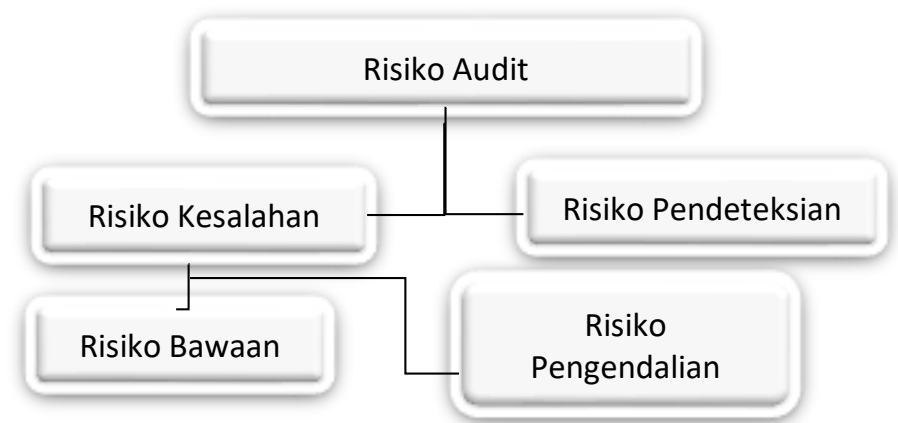

Gambar :10.5 Risiko audit

Sumber : (Henning Kagermann, 2008)

Risiko pengendalian merupakan risiko yang tidak terdeteksi atau tidak dapat dicegah oleh semua sistem yang relevan dari sistem pengendalian internal yang diterapkan. Di sini mungkin ada dua alasan untuk ini:

a. Risiko pengendalian dipicu hanya setelah penundaan waktu, yang berarti bahwa kesalahan diidentifikasi terlambat, atau aspek-aspek tertentu yang tidak 
diperiksa karena pengendalian internal tidak efektif sepanjang waktu.

b. Risiko deteksi adalah komponen utama risiko audit lainnya. Ini mengkuantifikasi kemungkinan bahwa meskipun pengujian rinci, auditor tidak dapat mendeteksi kesalahan material, misalnya karena mereka telah memilih jumlah sampel yang tidak memadai atau metode audit yang tidak sesuai. Tidak seperti komponen lainnya, auditor karena itu dapat secara langsung mempengaruhi risiko deteksi dengan memilih jenis dan tingkat kerja lapangan.

c. Untuk alasan efisiensi, hanya risiko material yang dimasukkan dalam perencanaan audit. Karena ketiga komponen risiko audit dapat saling menghapus atau memperkuat, risiko audit ditentukan dengan melipat gandakan komponennya

Risiko audit

$=$ risiko inheren $X$ risiko pengendalian $X$ risiko deteksi

Setelah keseluruhan risiko audit yang dapat diterima telah ditetapkan dan risiko yang melekat dan risiko pengendalian telah ditentukan, risiko deteksi yang dapat ditoleransi dapat ditetapkan. Auditor harus tetap dalam level risiko yang ditoleransi dengan melakukan kerja lapangan yang sesuai. Namun, tidak praktis untuk menentukan tingkat risiko yang tepat secara matematis, sehingga kategori risiko umum (rendah, sedang, tinggi) digunakan dalam praktik.

Dari perspektif risiko, empat pendekatan untuk analisis risiko digunakan sebagai bagian dari pendekatan audit berbasis risiko:

a. analisis risiko umum,

b. prosedur audit analitis, 
c. Pekerjaan lapangan berbasis sistem dan proses,

d. pengujian substantif.

Dalam analisis risiko, area risiko bisnis ditentukan dan risiko yang relevan diidentifikasi dalam konteks risiko audit secara keseluruhan. Objek audit ditentukan dan audit direncanakan berdasarkan hasil analisis risiko.

Prosedur audit analitik umum digunakan untuk menilai risiko secara umum di tingkat proses. Prosedurnya terdiri dari analisis angka dan rasio individu atau kelompok angka dan rasio. Pendekatan ini dimaksudkan untuk memungkinkan auditor mendapatkan gambaran umum tentang keandalan manajemen risiko dan sistem pengendalian internal. Prosedur audit analitik juga membantu memberikan tinjauan global tentang proses dan pengendalian unit yang diaudit dan mengidentifikasi setiap ketergantungan.

Kerja lapangan sistem yang terperinci membantu menguji keandalan dan efektivitas pengendalian internal. Ini juga digunakan untuk menilai risiko proses utama. Pengujian ini didasarkan pada perbandingan antara standar yang berlaku atau aturan internal perusahaan dengan proses atau situasi aktual di unit yang diaudit. Pengujian substantif adalah tinjauan terperinci atas masing-masing penyebab risiko material atau proses spesifik.

Kuesioner yang dapat diedarkan oleh auditor internal untuk mendapatkan informasi dari unit organisasi dan lingkungannya di mana mereka berencana untuk melakukan audit internal. Hasil kuesioner itu harus membantu auditor internal untuk merencanakan tinjauannya, termasuk hal-hal seperti ukuran dan jenis barang yang akan diambil sampel 
serta kebutuhan untuk tinjauan pengendalian aplikasi TI apa pun.

Audit internal yang efektif umumnya tidak dapat dilakukan oleh audit internal yang bekerja hanya dikantor perusahaan dan mengumpulkan bukti audit melalui pesan email dan pertanyaan. Dalam hampir semua kasus, auditor internal harus mengunjungi lokasi auditee dan mengamati operasi. Meskipun kadang-kadang hanya hasil dari kesan umum, auditor internal biasanya dapat belajar banyak dengan menghabiskan waktu di lokasi auditee. Apakah itu memperhatikan seorang manajer yang selalu datang sangat terlambat, seorang analis yang tampaknya tidak mengikuti prosedur keamanan TI yang baik, atau salah satu dari banyak pengamatan auditor internal lainnya, auditor internal di lokasi harus mengamati kegiatan dan tindakan ini saat melakukan audit lapangan. Banyak dari pengamatan ini mungkin tidak menghasilkan rekomendasi audit internal formal, tetapi mereka akan membantu auditor internal untuk mendapatkan pemahaman menyeluruh tentang unit yang diaudit.

Tugas yang jauh lebih penting yang dimiliki auditor daripada melakukan pengamatan adalah mengembangkan pemahaman yang baik tentang materi yang mereka kaji, menyiapkan dokumentasi untuk mendukung atau memperbarui materi yang ada, dan kemudian menggunakan materi itu untuk mengidentifikasi kerentanan pengendalian internal apa pun atau untuk membantu internal pemahaman audit tentang proses yang sedang ditinjau.

Jika auditor internal menemukan bahwa proses yang didokumentasikan tidak akurat, dalam kebanyakan kasus 
dokumentasi yang disiapkan perlu direvisi. Namun, dalam beberapa situasi, wawancara selama walk-through dapat mengidentifikasi potensi kelemahan pengendalian internal.

\section{c. Melaksanakan Prosedur Audit Internal}

Dengan asumsi bahwa proses yang didokumentasikan adalah benar dan lengkap, audit internal perlu mengidentifikasi area pengendalian internal utama dan kemudian mengembangkan tes audit untuk memverifikasi bahwa pengendalian tersebut berfungsi. Ukuran dan jenis tes ini sangat tergantung pada sifat dan kekritisan proses yang ditinjau.

Pengambilan sampel audit, bisa menggunakan prosedur statistik dan non-statistik dan mengevaluasi bukti audit. Semua auditor internal harus memiliki setidaknya pemahaman umum tentang proses pengambilan sampel audit statistik. Ini memungkinkan auditor internal untuk menyatakan dengan keyakinan terkait pernyataan pengendalian internal ada dan berfungsi sehingga saldo akun sudah benar.

Dalam menggambarkan lingkungan secara umum fungsi audit internal telah membawa beberapa program audit yang telah ditetapkan untuk area yang akan diuji dan dievaluasi. Namun, dalam banyak kasus, tim audit internal di lokasi dapat menemukan kebutuhan untuk melakukan sedikit penyesuaian pada program audit yang telah disiapkan. Dalam keadaan seperti itu, tim audit internal harus mendapatkan persetujuan untuk setiap program audit atau perubahan prosedur dari manajemen audit internal, dan kemudian melanjutkan untuk melakukan langkah-langkah audit yang sebenarnya seperti yang didokumentasikan. 
Memahami kompleksitas area yang diaudit akan menentukan serangkaian prosedur yang akan dilakukan terkait dengan rentang waktu yang diperlukan dan sumberdaya audit yang dibutuhkan dan banyak faktor lainnya. Terlepas dari ukurannya, tim audit internal perlu mengembangkan kertas kerja audit internal yang efektif, baik dalam hard-copy tradisional atau kertas kerja soft-copy di laptop auditor.

Setelah tim audit internal di lokasi menyelesaikan tes auditnya dan melakukan prosedur audit internal lainnya, ada kebutuhan untuk menyelesaikan pekerjaan lapangan audit. Meskipun laporan hasil audit dan bahkan draft laporan akhir mungkin tidak lengkap sebelum audit internal menyelesaikan pekerjaan lapangan mereka, auditor internal di lokasi memberikan setidaknya satu ringkasan pengamatan audit dan temuan potensial kepada manajemen lokal. dan rekomendasi.

\section{E. Simpulan}

Auditor internal harus menyusun perencanaan audit berbasis risiko untuk menetapkan prioritas kegiatan aktivitas audit internal sesuai dengan tujuan organisasi. Untuk membangun perencanaan audit internal berbasis risiko, auditor kepala konsultasi kepada manajemen senior dan dewan untuk memperoleh suatu pemahaman mengenai strategi organisasi, tujuan kegiatan kunci, risiko-risiko terkait, dan proses manajemen risiko. Auditor kepala harus mengkaji dan menyesuaikan perencanaan seperlunya untuk merespon perubahan dalam berbagai hal: usaha, risiko, operasi, program, sistem, dan pengendalian organisasi.

Struktur rencana audit tahunan mengikuti struktur tim audit. Hal ini untuk memastikan alokasi audit yang tepat sesuai dengan 
tanggung jawab tim dan diurutkan sesuai dengan prioritas atau peringkat risiko potensial. Auditor internal tidak akan mampu menyelesaikan masalah jika kemampuan berfikirnya masih pada level yang sama ketika masalah itu terjadi. Lingkungan bisnis terus berkembangan seiring dengan revolusi industri sekarang lingkungan bisnis berada pada revolusi industri 4.0. dari perkembangan teknologi menjadi perkembangan teknologi informasi. Perkembangan teknologi informasi yang sangat pesat dan intensif telah membawa perubahan dalam pola bisnis di segala jenis industri.

Sekarang ini risiko ada dimana-mana dan oleh karena itu, pemahaman yang baik mengenai nilai-nilai sangat menentukan bagaimana perusahaan merespon sebuah risiko melalui sebuah pengendalian akan membuat perusahaan mampu bersikap serta memitigasi risiko dengan baik.

F. Contoh Kasus Perencanaan Audit Berbasis Risiko di Era COVID 19. Organisasi tidak dapat mencegah pandemi. Namun, organisasi dapat membuat rencana terhadap dampaknya. Disisi lain, hal ini memungkinkan sebagian besar tenaga kerja untuk fokus dalam melanjutkan bisnis utamanya. Organisasi harus merencanakan skenario yang kemungkinan menghasilkan peningkatan atau penurunan permintaan untuk produk dan/atau layanan selama pandemi. Misalnya, produsen alat uji, masker medis, pembersih tangan, atau produk lain yang dibutuhkan selama pandemic, harus mengembangkan rencana untuk meningkatkan produksi dengan cepat.

Berikut adalah beberapa alasan melakukan audit internal jarak jauh; Sebagaimana yang diamanatkan oleh Undang-Undang Keamanan Transportasi Maritim (Maritime Transportation Security Act/MTSA) serta Hukum Anti-Terorisme Bangunan Fasilitas Kimia (Chemical Facility Anti-Terrorism Facility Statutes/CFATS), telah mendorong 
untuk mencari alternatif atas audit tradisional melalui tatap muka langsung. Fasilitas yang tercakup dalam peraturan tersebut mempersyaratkan audit internal harus dilakukan setiap tahun. Proses audit jarak jauh merupakan pendekatan yang menjanjikan, terutama jika mengingat satu atau dua hari perjalanan dapat dihemat per fasilitas apabila auditor tidak melakukan perjalanan ke lokasi.

Alasan lain untuk melakukan proses audit jarak jauh antara lain:

a. Tempat kerja yang sulit atau berbahaya untuk dikunjungi, seperti yang berlokasi di daerah yang terkena dampak kerusuhan politik, atau di mana perjalanan ke atau dari wilayah hukum dibatasi.

b. Situasi di mana tinjauan dengan volume yang tinggi diperlukan dalam jangka waktu yang singkat, seperti inisiatif audit yang berkaitan dengan akuisisi atau pengurangan risiko

\section{Pertanyaan untuk didiskusikan}

1. Mengapa rencana audit tahunan berdasarkan profil risiko yang ada pada unit kerja?

2. Bagaimana cara memahami lingkungan bisnis dalam audit internal?

3. Bagaimana cara memahami lingkungan pengendalian internal dalam audit internal?

\section{Soal kasus memahami proses bisnis.}

Memahami proses bisnis akan mendorong auditor internal untuk ikut berfikir kreatif dalam mencari alternatif solusi dalam meningkatkan proses bisnis yang mengasilkan output yang kurang atau belum optimal.

Ada proses evaluasi dan analisis yang menggunakan knowledge. Ada proses sharing knowledge setiap menemukan sebuah isu dalam peneriksaan yang mengarah pada penciptaan solusi yang objektif dan dapat dieksekusi untuk perbaikan. Dan yang paling penting adalah kerelaan spirit unit operasional dalam 
menindaklanjuti secara konsisten atas cara solusi tersebut hingga ada cara baru yang lebih baik lagi.

Peran dari auditor internal adalah untuk menambah nilai melalui fungsi assurance dan consulting dengan mrngevaluasi efektifitas control, risk management dan governance processes.

Oleh karena itu, dalam setiap perannya, auditor internal diharuskan untuk stay focus mengidentifikasi proses-proses bisnis melalui bukti-bukti yang baik serta pengujian-pengujian yang detail dan correlated.

Bagaimana cara anda mengidentifikasi proses bisnis untuk mengevaluasi pengendalian internal kas dan menentukan risiko atas pengendalian internal kas?

\section{Daftar Pustaka}

Asosiasi Auditor Intern Pemerintah Indonesia. (2018). Pedoman

Perencanaan Audit Berbasis Risiko Auditor Intern Pemerintah Indonesia.

Henning Kagermann, at all. (2008). Internal Audit Handbook. Springer-Verlag Berlin Heidelberg.

https://jonnygultom.wordpress.com.

(2019).

https://jonnygultom.wordpress.com/2019/10/20/riskculture/.

IIARF. (2009). Internal Audit Capability Model (IA-CM): For the Public sector, 2009.

Moeller, R. R. (2016). Brink's Modern Internal Auditing Eighth Edition A Common Body of Knowledge Published by John Wiley \& Sons, Inc., Hoboken, New Jersey. 


\section{BAB 11}

\section{PELAKSANAAN AUDIT INTERNAL}

\section{Capaian Pembelajaran}

1. Mahasiswa mampu mengorganisasi dan merencanakan audit internal.

2. Mahasiswa mampu memahami aktivitas persiapan audit internal.

3. Mahasiswa mampu mengembangkan program audit.

4. Mahasiswa mampu melaksanakan audit internal.

5. Mahasiswa mampu melaksanakan audit internal individu

\section{A. Pendahuluan}

Setelah audit internal mengidentifikasi dan memilih area untuk tinjauan audit internal, langkah selanjutnya adalah mengalokasikan sumber daya audit internal, mengumpulkan informasi pendukung tambahan sesuai kebutuhan, memulai proses mengumumkan dan meluncurkan audit internal. Terdapat enam kriteria titik penekanan pemilihan pelaksanaan audit karena perusahaan menghadapi beberapa kebutuhan berbeda untuk meluncurkan tinjauan audit internal, dan auditor kepala harus bekerja sama dengan komite audit untuk memastikan bahwa semua pihak memahami misi dan peran audit internal dalam peluncuran dan melakukan audit internal. Auditor internal harus memilih salah satu titik penekanan untuk memulai dan meluncurkan audit internal adalah:

a. Reorganisasi perusahaan, audit ini dilakukan ketika terdapat;

1) tuduhan hukum besar. 
2) akuisisi bisnis baru

3) penjualan unit operasi

b. Permintaan formal komite audit. Rencana audit internal tahunan menjadi pendorong utama kegiatan audit internal atas permintaam komite audit.

c. Permintaan untuk menjadwalkan audit oleh manajemen senior atau auditor eksternal. Anggota dewan, manajemen senior, atau audit eksternal dapat meminta audit internal yang mencakup beberapa kegiatan.

d. Perlunya audit tindak lanjut berdasarkan hasil audit sebelumnya. Audit khusus harus dijadwalkan untuk mencakup bidang-bidang ini secara lebih rinci jika jadwal dan sumber daya audit internal memungkinkan.

e. Audit khusus dilakukan atas permintaan manajemen lokal atau unit. Tim audit internal sering menerima permintaan untuk audit tambahan atau lebih rinci di beberapa area. auditor kepala harus memeriksa permintaan ini dan merencanakan audit.

f. Area lain yang dapat diaudit yang diidentifikasi dalam audit universe tetapi tidak dalam rencana audit internal tahunan yang disetujui.

Model proses standar GIAS, roadmap audit, terdiri dari fase-fase berikut (BDO, 2015):
a. Planning,
b. Preparation
c. Execution
d. Reporting and
e. Follow-up. 


\section{B. Mengorganisasi dan Merencanakan Audit Internal}

\section{Mengorganisasi Audit Internal}

Ketika membentuk tim audit internal harus memperhatikan diantaranya;

a. Mengacu pada Standar Internasional IIA untuk Praktik Profesional Audit Internal

b. Area yang diaudit

c. Luas dan kompleksitas unit yang diaudit

d. Pengetahuan tim audit tentang alat pendukung pedoman audit

Auditor internal membutuhkan berbagai keterampilan yang saling terkait. Namun, sebelum fungsi audit internal meluncurkan audit yang direncanakan, ia perlu memiliki beberapa peta untuk membangun sumber daya atau fungsi audit internal yang efektif. Peta fondasi audit internal ini meliputi:

a. Rencana atau organisasi yang efektif untuk meluncurkan kegiatan audit internal.

b. Rencana audit tahunan jangka panjang. Audit internal unit kerja harus didasarkan pada rencana kegiatan keseluruhan audit internal.

c. Pendekatan standar, efektif untuk melakukan audit internal. Seperti Standar Internasional IIA untuk Praktik Profesional Audit Internal, persyaratan mendasar untuk semua audit internal, dan kompetensi utama yang diperlukan untuk melakukan audit internal.

d. mengembangkan pendekatan yang baik untuk mengevaluasi bukti audit, dan pelaporan hasil audit yang efektif 
e. pemahaman yang kuat tentang kerangka kerja pengendalian internal coso

f. kerangka kerja yang konsisten untuk mengevaluasi pengendalian internal.

Fungsi audit internal perusahaan, akan lebih efektif jika semua anggota staf audit mengikuti prosedur profesional yang konsisten dalam melakukan tinjauan mereka.

Banyak standar dan persyaratan hukum yang menangani proses audit internal secara langsung, atau struktur pengendalian internal organisasi. Untuk fungsi audit internal, undang-undang dan standar yang harus ditaati ketika melakukan audit, antara lain;
a. Sarbanes Oxley Act of 2002 (SOX).
b. NYSE Standar Daftar,
c. Kerangka Kerja Terpadu Pengendalian Internal COSO,
d. Kerangka Kerja Terpadu Manajemen Risiko Perusahaan coso.
e. Tujuan Kontrol COBIt $^{\circledR}$ untuk Informasi dan teknologi terkait.

\section{Merencanakan Audit Internal}

Auditor Internal harus menyusun dan mendokumentasikan rencana untuk setiap penugasan audit yang mencakup;
a. tujuan penugasan,
b. ruang lingkup,
c. waktu, dan
d. alokasi sumber daya.

Rencana penugasan harus mempertimbangkan strategi organisasi, tujuan dan risiko-risiko yang relevan untuk 
penugasan itu. Dalam merencanakan penugasan, auditor internal harus mempertimbangkan:

a. Strategi dan sasaran dari kegiatan yang sedang diperiksa dan mekanisme yang digunakan dalam mengendalikan kinerjanya

b. Risiko signifikan atas sasaran, sumber daya, dan operasi aktivitas yang diperiksa, dan bagaimana menurunkan dampak risiko tersebut sampai pada tingkat yang dapat diterima,

c. Kecukupan dan efektivitas tata kelola, manajemen risiko dan proses pengendalian dibandingkan dengan kerangka kerja atau model yang relevan,

d. Peluang untuk meningkatkan secara signifikan tata kelola, manajemen risiko, dan proses pengendalian.

Auditor Internal harus melakukan penilaian pendahuluan terhadap risiko yang relevan atas kegiatan yang dikaji. Auditor Internal harus mempertimbangkan kemungkinan timbulnya kesalahan yang signifikan, kecurangan, ketidaktaatan, dan eksposur lain pada saat menyusun tujuan penugasan.

Kriteria yang memadai diperlukan untuk mengevaluasi tata kelola, manajemen risiko, dan pengendalian. Auditor Internal harus memastikan seberapa jauh manajemen telah menetapkan kriteria memadai untuk menilai apakah tujuan dan sasaran telah tercapai. Apabila memadai, auditor internal harus menggunakan kriteria tersebut dalam evaluasinya. Apabila tidak memadai, auditor internal harus mengidentifikasi kriteria evaluasi yang sesuai melalui diskusi dengan manajemen. 
Auditor Internal harus menyusun dan mendokumentasikan program kerja untuk mencapai tujuan penugasan. Program kerja harus mencakup prosedur untuk mengidentifikasi, menganalisis, mengevaluasi, dan mendokumentasikan informasi selama penugasan. Program kerja penugasan penjaminan dan konsultansi berbeda dalam bentuk dan isinya, tergantung pada sifat setiap penugasan

\section{Aktivitas Persiapan Audit Internal}

Setiap audit internal harus direncanakan dengan hati-hati sebelum dimulai. Audit harus dimulai sebagai elemen terjadwal dalam perencanaan tahunan dan proses penilaian risiko melalui;

a. permintaan khusus manajemen atau komite audit atau sebagai respons terhadap peristiwa yang tidak direncanakan, seperti penemuan kecurangan, peraturan baru, atau peristiwa ekonomi yang tidak terduga.

b. pembaruan beberapa pengendalian intern dan pengujian sebagai bagian dari tinjauan proses kunci

Perencanaan audit untuk peninjauan pertama kali atau audit yang diidentifikasi karena beberapa peristiwa yang tidak terduga, audit internal perlu mengembangkan rencana.

Setelah auditor membuat rencana tahunan, perencanaan dan penjadwalan audit internal individual. Terkadang ada permintaan dari manajemen yang tidak masuk jadwal audit tahunan.

Setelah kebutuhan untuk audit pertama kali telah diidentifikasi, langkah selanjutnya adalah menegaskan kembali tujuan audit yang spesifik, mengerjakan pengaturan logistik untuk tinjauan, dan kemudian mengembangkan rencana audit individu yang terperinci. 


\section{Tentukan Tujuan Audit}

Pernyataan tujuan tingkat tinggi harus ditetapkan untuk setiap audit yang direncanakan. Pernyataan tujuan tidak harus menjadi daftar persyaratan yang terperinci tetapi harus memiliki informasi yang memadai untuk memberi tahu pihak yang diaudit tentang apa yang ingin dicapai oleh audit internal di beberapa area audit. Berikut adalah beberapa contoh pernyataan tujuan audit internal untuk pembelian dan hutang dagang:

a. Untuk menilai kecukupan pengendalian akuntansi internal sistem pembelian serta proses pembelian, proses antarmuka ke sistem hutang dagang di kantor cabang dan kantor pusat, dan sistem otomatis untuk mendukung proses ini.

b. Untuk memperbarui proses yang terdokumentasi dan menguji pengendalian intern, sebagaimana diperlukan, untuk proses manajemen aset tetap untuk memenuhi persyaratan SOx bagian 404.

c. Untuk meninjau pengendalian intern yang ada selama pemeliharaan database manajemen konfigurasi TI dan prosedur pendukung.

Masing-masing contoh pernyataan tujuan audit menggambarkan apa yang direncanakan untuk diselesaikan oleh auditor internal dalam tinjauan yang akan datang. Sementara penugasan audit dapat diperluas saat tinjauan dimulai, pernyataan tujuan audit dilakukan ketika audit internal diluncurkan.

Tujuan awal dan pernyataan ruang lingkup audit internal harus ditinjau oleh manajemen atau pihak lain yang meminta 
audit apa yang direncanakan untuk diselesaikan oleh audit internal,

a. siapa yang akan melakukan peninjauan, dan

b. perkiraan waktunya.

\section{Jadwal Audit dan Perkiraan Waktu}

\begin{tabular}{|c|c|c|c|c|c|c|}
\hline \multirow[t]{2}{*}{ No } & \multirow[t]{2}{*}{ Aktivitas } & \multicolumn{5}{|c|}{ Minggu ke } \\
\hline & & 1 & 2 & 3 & 4 & 5 \\
\hline 1 & Tinjau aktivitas masa lalu dan nilai risiko & $\mathrm{X}$ & & & & \\
\hline 2 & $\begin{array}{l}\text { Kembangkan pendekatan audit dan } \\
\text { rencana awal }\end{array}$ & $\mathrm{X}$ & & & & \\
\hline 3 & Kontak audite untuk menjadwalkan audit & $\mathrm{X}$ & & & & \\
\hline 4 & Peninjauan ke lokasi & $X$ & & & & \\
\hline 5 & Tinjau dan dokumentasikan proses bisnis & & $\mathrm{X}$ & & & \\
\hline 6 & $\begin{array}{l}\text { Lakukan walk-through untuk } \\
\text { memverifikasi }\end{array}$ & & $\mathrm{x}$ & $\mathrm{x}$ & & \\
\hline 7 & $\begin{array}{l}\text { Kembangkan dan lakukan tes } \\
\text { pengendalian intern }\end{array}$ & & & $x$ & $X$ & \\
\hline 8 & $\begin{array}{l}\text { Lakukan prosedur audit lain sesuai } \\
\text { rencana }\end{array}$ & & & & $x$ & \\
\hline 9 & Ringkas dan konfirmasi hasil audit & & & $x$ & $x$ & \\
\hline 10 & Lengkapl Kertas kerja audit & & & & $x$ & \\
\hline 11 & Jadwalkan rapat penutupan audit & & & & $x$ & \\
\hline 12 & $\begin{array}{l}\text { Menyiapkan draf laporan audit dengan } \\
\text { rekomendasi }\end{array}$ & & & & & $\mathrm{X}$ \\
\hline
\end{tabular}

Gambar : 11.1 Rencana Audit Individu

Sumber : ( Moeller. R.R,2016)

Perkiraan waktu awal ditetapkan untuk melakukan setiap audit. Namun, perubahan sering dilakukan karena meningkatnya kebutuhan audit lain diluar jadwal yang 
sedang berlangsung, revisi lingkup audit, perubahan personel, dan prioritas manajemen lainnya.

Selain rencana tahunan dan setiap revisi yang diperlukan, jadwal audit individu harus disiapkan berdasarkan rencana ini. Bergantung pada sifat audit yang dilakukan dan ukuran staf audit dan jadwal individual. Untuk kelompok audit internal yang lebih besar, jadwal audit terperinci harus disiapkan untuk seluruh departemen audit serta auditor individual dan ditinjau setidaknya setiap bulan untuk mencerminkan perubahan atau penyesuaian.

Jumlah dan tingkat staf yang diperlukan untuk berbagai audit tergantung pada evaluasi sifat dan kompleksitas audit serta kemampuan auditor internal dan batasan waktu. Tentu saja, rencana yang dikembangkan pada tahap awal audit seringkali harus disesuaikan setelah lebih banyak informasi diperoleh.

Keterampilan auditor dan kebutuhan pengembangan harus dipertimbangkan dalam memilih personil untuk setiap tugas proyek audit. Setelah memutuskan segmen audit individu, keterampilan yang dibutuhkan untuk melakukan tugas audit harus ditentukan. Jika rencana adalah untuk tinjauan berulang, langkah pertama yang baik adalah melakukan survei pendahuluan untuk mengumpulkan bahan latar belakang mengenai entitas yang akan diaudit. Survei ini seringkali menjadi tanggung jawab manajemen audit. 


\section{Survei Awal Audit Internal}

\begin{tabular}{|l|l|l|l|l|l|l|}
\hline \multicolumn{7}{|c|}{ Departmen Audit Internal } \\
\hline \multicolumn{7}{|c|}{ Jam Jadwal Proyek Audit Bulan Februari, Maret, dan April } \\
\hline $\begin{array}{l}\text { Projec } \\
\text { t }\end{array}$ & Audit & Auditor & Activity & $\begin{array}{l}\text { Pe } \\
\text { br } \\
\text { (ja } \\
\text { m) }\end{array}$ & $\begin{array}{l}\text { Ma } \\
\text { (ja } \\
\text { m) }\end{array}$ & $\begin{array}{l}\text { Apr } \\
\text { (ja } \\
\text { m) }\end{array}$ \\
\hline $\begin{array}{l}\text { A23- } \\
\text { 06 }\end{array}$ & $\begin{array}{l}\text { Reviu } \\
\text { Pembelian }\end{array}$ & $\begin{array}{l}\text { Hollerit } \\
\text { h }\end{array}$ & $\begin{array}{l}\text { Uji } \\
\text { Kontrol IT }\end{array}$ & 20 & 80 & 45 \\
\hline $\begin{array}{l}\text { A23- } \\
\text { 06 }\end{array}$ & $\begin{array}{l}\text { Reviu } \\
\text { Pembelian }\end{array}$ & Spatz & $\begin{array}{l}\text { Proses } \\
\text { dokumen }\end{array}$ & $\begin{array}{l}11 \\
0\end{array}$ & 24 & 12 \\
\hline $\begin{array}{l}\text { A23- } \\
\text { 06 }\end{array}$ & $\begin{array}{l}\text { Reviu } \\
\text { Pembelian }\end{array}$ & Prusch & $\begin{array}{l}\text { Tes } \\
\text { transaksi }\end{array}$ & 36 & 80 & 12 \\
\hline $\begin{array}{l}\text { A23- } \\
\text { 06 }\end{array}$ & $\begin{array}{l}\text { Reviu } \\
\text { Pembelian }\end{array}$ & Tuttle & $\begin{array}{l}\text { Mengelol } \\
\text { a audit }\end{array}$ & 12 & 18 & 20 \\
\hline $\begin{array}{l}\text { A28- } \\
78\end{array}$ & $\begin{array}{l}\text { KC } \\
\text { Penjualan }\end{array}$ & $\begin{array}{l}\text { Bushma } \\
\mathrm{n}\end{array}$ & $\begin{array}{l}\text { US West } \\
\text { Results }\end{array}$ & $\begin{array}{l}12 \\
0\end{array}$ & 14 & 30 \\
\hline $\begin{array}{l}\text { A28- } \\
78\end{array}$ & $\begin{array}{l}\text { KC } \\
\text { Penjualan }\end{array}$ & Lester & $\begin{array}{l}\text { US West } \\
\text { Results }\end{array}$ & 0 & 68 & 160 \\
\hline $\begin{array}{l}\text { A31- } \\
\text { 01 }\end{array}$ & $\begin{array}{l}\text { Riviu } \\
\text { Kontrol } \\
\text { Pekerjaan }\end{array}$ & Doe & $\begin{array}{l}\text { Proses } \\
\text { Documen }\end{array}$ & 0 & 64 & 80 \\
\hline $\begin{array}{l}\text { A31- } \\
\text { 01 }\end{array}$ & $\begin{array}{l}\text { Riviu } \\
\text { Kontrol } \\
\text { Pekerjaan }\end{array}$ & $\begin{array}{l}\text { Hollerit } \\
\text { h }\end{array}$ & $\begin{array}{l}\text { Uji } \\
\text { Kontrol IT }\end{array}$ & 0 & 40 & 40 \\
\hline $\begin{array}{l}\text { A31- } \\
\text { 01 }\end{array}$ & $\begin{array}{l}\text { Riviu } \\
\text { Kontrol } \\
\text { Pekerjaan }\end{array}$ & Tuttle & $\begin{array}{l}\text { Mengelol } \\
\text { a audit }\end{array}$ & 8 & 12 & 12 \\
\hline
\end{tabular}

Gambar : 11.2 Contoh Jadwal Proyek Rencana Audit

Sumber : ( Moeller. R.R, 2016) 
Berikut ini adalah item yang harus ditinjau, jika tersedia, selama survei pendahuluan audit internal (Kinney, Weber, Busch, \& Eckes, 2008):

a. Meninjau kertas kerja sebelumnya. Perhatian khusus harus diberikan pada setiap masalah yang dihadapi dalam audit sebelumnya dan metode penyelesaian yang disarankan.

b. Mengetahui jumlah waktu dari audit sebelumnya. Hasil pengujian sebelumnya harus ditinjau, untuk memutuskan apakah ada yang harus dikurangi, dihilangkan, diperluas.

c. Meninjau laporan audit sebelumnya. Temuan audit masa lalu dan signifikansinya harus selalu dipertimbangkan

d. Tindakan korektif yang direkomendasikan direkomendasikan. Perhatian khusus harus diberikan jika tindakan korektif substansial diperlukan dalam audit sebelumnya, sehingga audit yang direncanakan harus mencakup pemeriksaan bidang-bidang tersebut juga.

e. Organisasi entitas. Auditor internal harus mendapatkan bagan organisasi dari entitas untuk memahami struktur dan tanggung jawabnya. Perhatian khusus harus diberikan pada bidang-bidang di mana mungkin ada potensi masalah pemisahan tugas. Selain itu, jumlah karyawan dan nama-nama kontak karyawan kunci harus diperoleh. Data anggaran dan kinerja keuangan juga harus ditinjau sebagai bahan latar belakang. 
f. Bahan audit terkait lainnya. Data pendukung dari audit terkait yang direncanakan, sedang dalam proses atau yang diselesaikan harus dipelajari.

\section{Memulai Audit Internal}

Langkah pertama dalam memulai audit internal adalah memberi tahu audite bahwa audit internal telah dijadwalkan (Auditors, 2017). Kecuali untuk audit investigasi terkait kecurangan, di mana audit internal datang ke lokasi tanpa pemberitahuan sebelumnya. Pemberitahuan audit internal disebut "surat penugasan". Surat penugasan adalah dokumen perencanaan internal yang menginformasikan kepada audite mengenai;

a. kapan audit internal dijadwalkan,

b. siapa yang akan melakukan tinjauan,

c. mengapa audit dilakukan (terjadual, permintaan komite manajemen atau komite audit, dII.).

d. Pendekatan yang digunakan

Surat penugasan harus memberi tahu manajemen audite tentang hal-hal berikut

a. Penerima. Komunikasi harus ditujukan kepada manajer yang bertanggung jawab langsung atas unit yang diaudit.

b. Tujuan dan ruang lingku audit yang direncanakan. Pihak yang diaudit harus diberi tahu dengan jelas tentang tujuan audit internal yang direncanakan dan bidang-bidang yang akan dicakupnya.

c. Tanggal mulai yang diharapkan dan durasi audit yang direncanakan. Sebisa mungkin, surat perikatan harus memberi pemahaman kepada audite tentang waktu audit. 


\section{d. Orang yang bertanggung jawab untuk melakukan tinjauan.} Ini akan membantu manajemen audite untuk menentukan orang kunci ini jika tim auditor tiba di lokasi.

e. Kebutuhan persiapan awal. Setiap persyaratan yang diperlukan sebelum pemantauan lapangan atau di lokasi audit harus diuraikan. Ini mungkin termasuk salinan laporan tertentu sebelum pemantauan. Ini juga merupakan tempat yang tepat untuk meminta ruang sementara audit internal, akses jaringan sistem komputer, dan akses ke sistem atau basis data TI utama.

f. Salinan surat keterlibatan. salinan surat perikatan harus ditujukan kepada orang-orang yang tepat di perusahaan yang perlu tahu.

Berdasarkan keseluruhan tujuan audit, dokumen yang dibutuhkan diantaranya; laporan keuangan, statistik, dan lainnya harus diminta terlebih dahulu sebagai bagian dari memo perikatan. Laporan-laporan seperti ini dapat membantu mengidentifikasi tren atau memungkinkan perbandingan antar entitas untuk menentukan varian yang signifikan. Karena audit internal memiliki jadwal komprehensif jika ada permintaan penundaan dari audite, maka pantas untuk menolak permintaan penundaan dan bersikeras memulai audit sesuai rencana.

Begitu audit telah dijadwalkan dan audite diinformasikan, tim audit yang ditugaskan harus siap untuk mulai bekerja di lokasi audite. Fase audit ini disebut pekerjaan lapangan. Mungkin audit internal dilakukan pada lokasi terpencil biasanya pekerjaan lapangan sebagian besar terdiri dari ulasan melalui layar Web atau audit jarak jauh,. Pada titik ini, tim audit internal mengumpulkan informasi latar belakang seperti kebijakan dan prosedur yang 
relevan. Audit internal selanjutnya melakukan survei lapangan untuk meningkatkan pemahaman tim audit yang ditugaskan tentang area yang akan ditinjau serta untuk membuat dokumentasi audit awal. Dalam hal itu, dokumentasi kertas kerja harus diambil dan diperbarui untuk audit internal yang baru dijadwalkan.

\section{Survei Lapangan}

Survei pendahuluan seringkali sangat penting dalam menentukan arah, ruang lingkup terperinci, dan tingkat upaya audit. Survei lapangan memungkinkan auditor untuk;

a. membiasakan diri dengan proses lokal yang ada, dan

b. mengevaluasi struktur pengendalian dan tingkat risiko pengendalian dalam berbagai proses dan sistem pengendalian internal.

Survei lapangan merupakan waktu yang tepat bagi auditor untuk menjabarkan wawancara yang direncanakan dan untuk membuat jadwal pendahuluan. Elemen-elemen informasi berikut harus dikumpulkan oleh auditor selama survei lapangan diantaranya;

a. Organisasi. Selama survei lapangan, auditor harus memastikan bahwa bagan organisasi sudah benar dan menyertakan nama-nama personil kunci. Auditor harus memahami tanggung jawab fungsional dan orang-orang kunci yang terlibat dalam operasi. Jika fungsi tersebut tidak memiliki bagan yang tersedia pada saat survei pendahuluan, auditor harus menyusun bagan organisasi kasar dan meninjau asumsi-asumsi ini dengan manajemen pihak yang diaudit. 
b. Manual dan Arahan. Salinan manual kebijakan dan prosedur yang berlaku,.Hukum dan peraturan yang berlaku harus dipelajari, serta arahan manajemen untuk mematuhinya.

c. Laporan. Laporan manajemen yang relevan dan risalah rapat yang mencakup bidang yang sesuai dengan audit seperti penganggaran, operasi, studi biaya, dan masalah personel harus dianalisis.

d. Pengamatan pribadi. Walk-through dari auditor internal dengan entitas, untuk mengobservasi operasi dasar, personel, dan pemanfaatan ruang. Kesan yang diperoleh dari walk-through harus didokumentasikan dalam kertas kerja audit sebagai narasi.

e. Diskusi dengan personil kunci. Diskusi dengan personel kunci. Pertanyaan harus diajukan berdasarkan data awal yang ditinjau atau pengamatan walk-through.

Masalah atau kesalahpahaman berpotensi muncul pada saat survei, masalah-masalah ini harus diselesaikan pada saat penerbitan surat perikatan, manajemen unit mungkin tidak memahami apa yang diinginkan oleh auditor internal, atau audit internal mungkin tidak memiliki pemahaman yang benar tentang entitas. Hasilnya penyelesaian masalah antara auditor dengan audite mungkin menyebabkan penyesuaian;

a. ruang lingkup tinjauan yang direncanakan,

b. prosedur audit yang direncanakan.

\section{Mendokumentasikan Survei Lapangan}

Konsep audit tidak terlepas dari dokumentasi yang fokus dan akurat. Dokumentasi adalah salah satu dari banyak proses yang menyertai pekerjaan audit, dan tujuan utamanya adalah 
untuk menjelaskan semua kegiatan dan fakta yang berkaitan dengan audit. Mendokumentasikan survei lapangan adalah salah satu kunci keberhasilan setiap audit. Dokumentasi yang jelas dan komprehensif sangat penting untuk kepatuhan audit. Dokumentasi dalam Audit Internal memiliki tiga tujuan utama:

a. Tujuan pertama adalah untuk memberikan uraian terperinci tentang semua proses audit dan langkahlangkah proses. Dokumen ini mendokumentasikan bahwa struktur audit internal patuh dalam kaitannya dengan proses dan pengendalian internal terkait. Untuk alasan ini, semua langkah proses yang relevan, pengendalian internal, kaitannya dengan pelaporan keuangan harus dicatat, dengan mempertimbangkan persyaratan SOX. Pedoman dokumentasi harus diterapkan secara konsisten ke semua pelaksanaan yang memberikan bukti bahwa prinsip audit telah dipenuhi sesuai persyaratan SOX.

b. Bukti audit diperlukan untuk memastikan bahwa audit internal dapat menguatkan informasi yang diberikannya kepada semua pihak internal dan eksternal setiap saat. Untuk menjamin bahwa kesimpulan dan rekomendasi dapat dibuktikan, dokumentasi audit internal harus lengkap, jujur, tersedia, dapat dilacak, dan sedetail yang diperlukan.

c. Memberikan riwayat audit. Mengingat perubahan dinamis dalam kehidupan bisnis, pemantauan hasil audit berdasarkan dokumen adalah tugas penting untuk audit internal.

Tugas penting dalam setiap audit adalah menerapkan prinsip materialitas untuk membuat pemilihan yang benar dan 
bermakna dari sejumlah besar sumber dokumentasi yang tersedia. Untuk alasan ini, auditor harus memberikan waktu yang cukup untuk membuat dan meninjau dokumentasi

\section{Kesimpulan Survei Lapangan}

Tujuan dari survei lapangan audit internal adalah untuk mengkonfirmasi asumsi yang diperoleh dari perencanaan audit awal dan untuk mengembangkan pemahaman tentang sistem dan proses utama. Karena informasi yang mendukung perencanaan audit pendahuluan seringkali tidak sempurna, ini adalah poin penting di mana tim audit yang ditugaskan dapat melakukan penyesuaian terhadap ruang lingkup dan tujuan audit yang direncanakan. Untuk audit yang lebih besar, sering kali manajemen audit internal untuk mengunjungi tim yang melakukan survei lapangan dan meninjau hasil. Dengan cara ini, perubahan ruang lingkup disetujui oleh manajemen yang diperlukan dapat dilakukan secara cepat. Kehadiran di tempat ini dapat menjernihkan setiap pertanyaan potensial yang dapat diajukan kemudian.

Auditor internal dapat menemukan di mana informasi yang dikumpulkan dari survei lapangan dapat menyebabkan tim audit melakukan menyesuaikan ruang lingkup audit yang direncanakan secara substansial atau bahkan untuk membatalkan pekerjaan audit rinci. Hasil survei lapangan kadang dapat menunjukkan perubahan yang signifikan pada proses bisnis, seperti;

a. pengenalan sistem informasi baru, yang mengubah lingkungan pengendalian secara keseluruhan dan mungkin memerlukan tim audit internal spesialis yang menyebabkan penyesuaian staf dan strategi uji audit. 
b. perubahan sangat substansial sehingga audit yang direncanakan harus dibatalkan atau ditunda. Bahanbahan yang dikumpulkan dalam survei lapangan harus digunakan untuk memperbarui kertas kerja permanen.

\section{E. Mengembangkan Program Audit}

Audit internal harus diselenggarakan dan dilakukan secara konsisten dengan tujuan meminimalkan prosedur auditor yang tidak perlu. Untuk membantu mencapai tujuan konsistensi audit ini, auditor internal harus menggunakan apa yang disebut program audit untuk melakukan prosedur audit secara konsisten dan efektif untuk jenis audit serupa.

a. Program audit adalah serangkaian langkah yang telah ditetapkan sebelumnya yang harus dilakukan oleh auditor internal.

b. Program audit adalah alat untuk merencanakan, mengarahkan, dan mengendalikan pekerjaan audit dan cetak biru untuk tindakan, menentukan langkah-langkah yang harus dilakukan untuk memenuhi tujuan audit.

Departemen audit internal yang efektif harus memiliki serangkaian program audit standar yang disiapkan untuk sebagian besar kegiatan audit rutinnya.

Dalam beberapa situasi, program audit standar tidak akan berlaku. Misalnya, auditor internal meninjau pengendalian dalam entitas bisnis baru dengan beberapa karakteristik pengendalian yang unik. Berdasarkan tujuan audit yang direncanakan dan data yang dikumpulkan dalam survei pendahuluan dan lapangan, auditor mungkin ingin menyiapkan program audit yang disesuaikan untuk memandu tinjauan sehingga minimal auditor 
internal harus memiliki pemahaman tentang karakteristik program audit yang memadai.

\section{Format Program Audit dan Persiapannya}

Program audit adalah prosedur yang menggambarkan langkah-langkah dan tes yang harus dilakukan oleh auditor ketika melakukan pekerjaan lapangan.

a. Program audit harus dibangun dengan beberapa kriteria program harus mengidentifikasi aspek-aspek area yang akan diperiksa lebih lanjut dan area sensitif yang memerlukan penekanan audit.

b. Program audit harus membimbing auditor internal junior.

Program audit yang tepat mungkin tidak tersedia untuk banyak bidang. Hal ini karena auditor internal biasanya dihadapkan dengan serangkaian bidang yang luas dan beragam untuk ditinjau, dengan keterbatasan waktu atau sumber daya untuk meninjau setiap bidang secara berkala.

Program audit standar yang disiapkan untuk audit sebelumnya sering menjadi ketinggalan zaman karena sistem baru atau proses yang berubah. Auditor yang melakukan survei lapangan harus memperbarui program audit yang ada atau menyiapkan serangkaian langkah program audit yang direvisi untuk tinjauan yang direncanakan. seperangkat prosedur audit umum,

a. prosedur audit dengan instruksi terperinci untuk auditor, atau

b. daftar periksa untuk tinjauan kepatuhan.

Tim audit dapat menggunakan program audit standar untuk meninjau pengendalian intern secara konsisten dari 
satu unit ke unit berikutnya. Ini sangat penting dalam organisasi multi-unit di mana manajemen audit ingin memiliki kepastian bahwa pengendalian atas area tersebut ditinjau dan dievaluasi secara konsisten.

Perhatian utama adalah bahwa semua audit harus didukung oleh program audit yang mendokumentasikan langkah-langkah peninjauan yang dilakukan. Pendekatan ini memungkinkan manajemen audit untuk mengenali prosedur apa yang dilakukan atau tidak dilakukan. Program audit yang kuat dan konsisten adalah langkah penting dalam meningkatkan kualitas audit internal yang dilakukan secara keseluruhan.

Dalam mengembangkan program audit, auditor internal harus mencoba memilih langkah-langkah audit yang bermakna dan yang akan menghasilkan bentuk bukti audit yang andal.

Sebagai contoh, program audit seringkali perlu meminta pengujian terperinci dalam bidang kritis dan berisiko tinggi yang diberikan daripada informasi tersebut dapat dikumpulkan melalui wawancara.

\section{Jenis Bukti Audit}

Standar profesional IIA menyatakan bahwa auditor internal harus memeriksa dan mengevaluasi informasi tentang semua hal yang berkaitan dengan tujuan audit yang direncanakan. Informasi ini, yang disebut bukti audit, mencakup segala sesuatu yang ditinjau atau diamati oleh auditor internal. Auditor internal harus mengumpulkan bukti audit untuk mendukung evaluasi auditor.

Bukti audit yang memadai harus, kompeten, relevan, dan berguna. Program audit yang dibangun dengan baik 
harus memandu auditor internal dalam proses pengumpulan bukti. Auditor internal akan menghadapi berbagai tingkat bukti audit dan harus berusaha merancang prosedur audit untuk mencari dan mengandalkan bukti audit terbaik yang tersedia. Langkah-langkah pelaksanaan audit tergantung pada karakteristik entitas yang diaudit. Audit berorientasi kredit dari departemen penagihan dan kredit akan sangat berbeda dari tinjauan operasional fungsi rekayasa desain. Audit berorientasi kredit mencakup konfirmasi independen saldo akun, sementara audit operasional biasanya mencakup wawancara ekstensif dengan manajemen dan dokumentasi pendukung untuk menilai pengendalian intern utama.

\begin{tabular}{|l|l|l|}
\hline \multicolumn{1}{|c|}{$\begin{array}{c}\text { Klasifikasi } \\
\text { Bukti }\end{array}$} & \multicolumn{1}{|c|}{ Bukti Terkuat } & Bukti Telemah \\
\hline $\begin{array}{l}\text { Prosedur } \\
\text { teknik audit }\end{array}$ & Observasi/konfirmasi & $\begin{array}{l}\text { Pertanyaan } \\
\text { kausal }\end{array}$ \\
\hline Asal bukti & $\begin{array}{l}\text { Bahan-bahan yang } \\
\text { mendukung }\end{array}$ & $\begin{array}{l}\text { Berdasarkan } \\
\text { statistic }\end{array}$ \\
\hline $\begin{array}{l}\text { Hubungannya } \\
\text { dengan Audite }\end{array}$ & Dokumen Eksternal & $\begin{array}{l}\text { Dokumen } \\
\text { Internal Audite }\end{array}$ \\
\hline $\begin{array}{l}\text { Bentuk Bukti } \\
\text { Audit }\end{array}$ & $\begin{array}{l}\text { Ditulis dengan Tanda } \\
\text { Tangan }\end{array}$ & Komentar Lisan \\
\hline $\begin{array}{l}\text { Kecanggihan } \\
\text { Bukti }\end{array}$ & Dokumentasi Resmi & $\begin{array}{l}\text { Informal } \\
\text { (memo) }\end{array}$ \\
\hline Lokasi bukti & $\begin{array}{l}\text { Terhubung ke Area } \\
\text { Ditinjau }\end{array}$ & $\begin{array}{l}\text { Bahan Turunan/ } \\
\text { Pendukung }\end{array}$ \\
\hline Sumber bukti & $\begin{array}{l}\text { Produk Pekerjaan } \\
\text { Audit Internal }\end{array}$ & $\begin{array}{l}\text { Bahan } \\
\text { Pendukung } \\
\text { Lainnya }\end{array}$ \\
\hline
\end{tabular}

Gambar 11.3 Klasifikasi "Bukti Terbaik" Audit Internal Sumber : ( Moeller. R.R,, 2016) 


\section{F. Melaksanakan Audit Internal}

Langkah-langkah umum audit internal harus digunakan bersama dengan prosedur audit spesifik. Memahami bagaimana melakukan audit internal benar-benar merupakan persyaratan utama auditor internal.

\section{Prosedur Pekerjaan Lapangan Awal}

Auditor mengadakan pertemuan dengan anggota manajemen audite untuk menjabarkan rencana awal audit, termasuk menjelaskan hal-hal berikut;

a. bidang yang akan diuji,

b. laporan atau dokumentasi khusus yang diperlukan,

c. personel yang akan diwawancarai.

d. berkeliling dan bertemu personel unit lainnya.

e. auditor meminta agar manajemen menghubungi semua anggota organisasi yang diaudit

Walaupun rencana audit sudah disusun secara baik, masalah masih dapat terjadi saat melakukan audit. Setiap masalah harus dideteksi sejak awal penugasan dan dipecahkan sesegera mungkin. Jika tim audit internal menghadapi kurangnya kerja sama, manajemen harus diberi informasi pada tingkat yang sesuai untuk menyelesaikan masalah tersebut. Baik auditor internal maupun audite selalu ingat bahwa keduanya adalah anggota dari keseluruhan perusahaan yang sama dengan kepentingan dan tujuan umum yang sama.

Pekerjaan audit harus mengikuti program audit yang ditetapkan. Ketika setiap langkah selesai, auditor harus menginisialisasi dan menentukan tanggal program audit. Dokumentasi yang dikumpulkan dari setiap langkah audit, 
serta setiap analisis audit, harus diorganisir dan diteruskan ke auditor yang bertanggung jawab, untuk melakukan tinjauan pendahuluan atas pekerjaan audit. Ketua auditor memantau kinerja pekerjaan audit yang sedang berlangsung dan meninjau kertas kerja saat tim audit menyelesaikan setiap langkah.

Lembar poin harus selalu direferensikan silang dengan kertas kerja audit yang spesifik, dan status poin yang diajukan harus didokumentasikan untuk menunjukkan disposisi akhirnya. Jika dikembangkan menjadi temuan, lembar poin juga dapat dirujuk silang ke laporan audit tersebut.

\section{Bantuan Teknis Kerja Lapangan Audit}

Survei lapangan atau proses pengembangan program audit mungkin telah mengidentifikasi kebutuhan untuk bantuan teknis khusus untuk melakukan audit internal. Jika masalah teknis tidak dipahami oleh tim audit, ketua auditor harus mencari bantuan sesegera mungkin. Spesialis audit internal mungkin harus meneliti audit dan memberi jawaban terkait masalah teknis.

Manajemen audit harus berkomunikasi dengan staf untuk semua masalah teknis harus disampaikan kepada ketua auditor untuk penyelesaian secepat mungkin. Segala biaya dan persyaratan waktu tambahan yang disebabkan oleh masalah teknis ini harus didokumentasikan.

\section{G. Pemantauan Kerja Lapangan}

Jika audit internal mencakup periode waktu yang panjang atau tingkat sumber daya yang diperlukan banyak, manajemen audit internal harus meninjau kemajuan audit dan memberikan 
arahan teknis melalui pemantauan dan komunikasi. Frekuensi dan luasnya pemantauan bergantung pada;

a. kekritisan tinjauan, pengalaman staf yang ditugaskan,

b. ukuran pelaksanaan audit internal.

Audit internal yang dipimpin oleh auditor yang berpengalaman dalam bidang-bidang yang sudah dikenal mungkin tidak memerlukan tinjauan manajemen jika jalur komunikasi baik. Namun, jika audit mencakup area kritis, penggunaan program audit baru, teknik baru bisa digunakan, dan jika ketua auditor memiliki pengalaman terbatas di area yang ditinjau, anggota manajemen audit yang berpengalaman harus mengunjungi audit kerja lapangan secara berkala.

Tujuan dari pemantauan ini adalah untuk meninjau pekerjaan yang sedang berlangsung dan untuk membantu menyelesaikan masalah yang dihadapi. Manajemen audit harus mengambil kesempatan ini untuk memahami masalah yang berkembang dalam audit dan menyarankan perubahan yang sesuai. Ini juga merupakan saat yang tepat bagi manajemen untuk memulai peninjauan kertas kerja audit yang telah diselesaikan.

Laporan kertas kerja audit internal tentang pekerjaan yang dilakukan menyediakan hubungan yang jelas antara prosedur yang didokumentasikan dalam program audit dengan hasil tes audit. Karena kertas kerja menjadi dasar untuk temuan dan rekomendasi dalam laporan audit akhir, kertas kerja harus mendokumentasikan semua pekerjaan audit dengan tepat.

Selanjutnya manajemen meninjau dan mengomentari kertas kerja audit melalui lembar poin audit. Lembar poin adalah alat jaminan kualitas audit internal dan harus diselesaikan oleh auditor di lapangan segera setelah ada indikasi bahwa ada masalah audit 
yang berpotensi substantif. Lembar point memfasilitasi untuk membawa isu-isu ini menjadi perhatian audit internal dan manajemen audite pada titik awal dalam tinjauan. Lembar point juga berfungsi sebagai pengendalian untuk memastikan bahwa semua petunjuk diikuti. Selain itu, berbagai lembar poin auditor, yang dikembangkan staf individu, dapat menghasilkan sejumlah masalah kecil jika diakumulasi bisa menunjukkan kondisi yang lebih serius secara keseluruhan.

\section{Temuan Audit Potensial}

Setiap kali auditor internal menemukan kekurangan yang potensial, harus membuat ringkasan singkat dari kondisi yang ditemukan, potensi temuan dan rekomendasi harus disiapkan. Ringkasan ini kadang-kadang muncul dalam lembar temuan pendahuluan audit. Temuan awal ini menggambarkan kekurangan atau peluang untuk perbaikan yang diidentifikasi selama audit. Temuan awal ini mungkin telah dikembangkan melalui lembar poin audit, atau melalui temuan dan pengamatan internal yang didokumentasikan. Temuan audit pendahuluan biasanya memiliki unsur-unsur berikut:

a. Identifikasi temuan. Beri nomor identifikasi untuk temuan audit dan deskripsi potensi temuan.

b. Kondisi audit yang diselesaikan. Deskripsi secara singkat untuk memberikan pemahaman manajemen lokal tentang kondisi yang ditemukan.

c. Referensi untuk pekerjaan audit yang didokumentasikan. Lembar poin audit harus berisi referensi silang dalam program audit serta beri komentar, serta di mana dokumen tersebut didokumentasikan dalam kertas kerja audit. 
d. Rekomendasi awal auditor. Ruang laporan audit harus digunakan untuk mendokumentasikan sifat temuan audit potensial dan apa yang salah.

e. Hasil dari diskusi dengan manajemen. Auditor yang bertanggung jawab harus membahas semua potensi temuan secara informal dengan manajer yang bertanggung jawab langsung atas masalah tersebut.

f. Disposisi yang direkomendasikan untuk masalah ini. Atas dasar diskusi dengan manajemen, auditor harus memasukkan komentar tentang disposisi temuan yang direkomendasikan.

\section{Modifikasi Program Audit dan Jadwal}

Program audit adalah panduan keseluruhan untuk melakukan audit internal yang dikembangkan dari data survei pendahuluan dan dari audit internal masa lalu, mungkin ada penyesuaian selama berlangsungnya tinjauan. Auditor harus responsif terhadap bukti baru, perubahan dalam sistem pendukung, dan perubahan kondisi lainnya. Pada tahap awal audit, mungkin perlu mengarahkan ulang beberapa staf untuk memodifikasi beberapa langkah program audit. Kebutuhan untuk modifikasi program audit paling sering terjadi ketika audit internal telah mengembangkan program audit umum untuk digunakan dalam tinjauan unit yang serupa tetapi tidak identik.

Misalnya, program audit mungkin telah dikembangkan untuk mencakup pengendalian atas fungsi pembelian untuk organisasi dengan beberapa unit pabrik berbeda-beda, masing-masing dengan fungsi pembelian terpisah. Program audit fungsi pembelian tersebut harus mencerminkan 
kebijakan organisasi dan prinsip-prinsip pengendalian internal umum. Namun, karena perbedaan lokal, program audit ini dapat berisi langkah-langkah yang tidak berlaku untuk satu atau beberapa area pembelian tertentu yang sedang diaudit. Setiap langkah program audit individual yang dilewati harus didokumentasikan sebagai alasannya.

Perubahan sering diperlukan dalam jadwal dan rencana audit saat pekerjaan berlangsung. Beberapa fleksibilitas harus diperhitungkan dalam rencana untuk memenuhi persyaratan yang tidak terduga. Selama penugasan audit lapangan, terdapat beberapa situasi yang dapat mempengaruhi kemajuan auditnya, seperti;

a. masalah atau peristiwa yang tidak terduga,

b. kebutuhan untuk memodifikasi atau menghentikan segmen program audit,

c. penemuan area baru untuk ditinjau, atau perubahan dalam audit personil.

d. ada selip dalam rencana karena persyaratan waktu tambahan untuk menyelesaikan langkah program audit. Dalam situasi seperti ini, anggaran perlu direvisi sesuai yang dibutuhkan dan harus disetujui oleh internal manajemen audit.

\section{Melaporkan Temuan Audit Pendahuluan}

Bidang utama yang ditekankan dalam audit internal adalah identifikasi area unit yang ditinjau dimana prosedur pengendalian intern tidak memadai dan diperlukan perbaikan (IIARF, 2009). Temuan audit potensial ini harus didiskusikan dengan audite, tim audit juga harus meninjau 
temuan audit potensial dengan manajemen unit sebelum meninggalkan penugasan audit lapangan.

Bergantung pada ruang lingkup dan ukuran audit, temuan-temuan potensial ini harus dianalisis pada beberapa titik selama peninjauan. Auditor dapat menjadwalkan pertemuan dengan manajemen unit setiap akhir minggu untuk membahas semua temuan yang dikembangkan selama minggu itu.

Jika temuan bersifat minor, bersifat prosedural, manajemen dapat mengambil tindakan korektif yang diperlukan sekaligus dan temuan tersebut dapat dihapus dalam laporan audit akhir.

\section{H. Menyelesaikan Pekerjaan Lapangan}

Audit internal harus dikelola dengan cara yang sama dengan proyek besar mana pun yang membutuhkan waktu dan sumber daya dan menghasilkan hal yang pasti. Produk kerja audit internal yang paling penting adalah laporan audit formal, dengan temuan dan rekomendasinya, yang dikirim ke pihak yang diaudit serta kepada komite audit setelah selesai peninjauan. Audit internal individu harus dianggarkan dengan waktu dan biaya yang diukur terhadap rencana tersebut.

Sistem pelaporan kinerja penugasan audit harus ditetapkan. Untuk audit yang berdurasi lebih dari sekitar dua minggu atau yang dilakukan di beberapa lokasi secara bersamaan, laporan kemajuan harus diminta setiap minggu atau setiap dua minggu. Laporan-laporan ini harus didasarkan pada ringkasan waktu dari staf audit yang ditugaskan serta komentar dari auditor yang bertugas di lokasi. Mereka dapat memasukkan informasi seperti waktu aktual untuk menyelesaikan, dan deskripsi singkat 
kemajuan program audit. Data ini dapat dikumpulkan oleh auditor pengawas di lokasi lapangan dan dikirim ke departemen audit internal pusat. Auditor harus bertanggung jawab untuk menjelaskan setiap perbedaan yang signifikan dalam audit aktual versus perencanaan.

Waktu yang dihabiskan untuk penugasan audit individual harus diringkas lebih lanjut oleh manajemen audit internal untuk memberikan gambaran umum dari semua audit yang direncanakan atau sedang dalam proses. Jenis laporan ini digunakan untuk memberikan pengendalian atas audit yang dijadwalkan atau sedang dalam proses sementara laporan terpisah yang lebih rinci dapat diselesaikan untuk setiap audit individu untuk memastikan bahwa audit dimulai dan diselesaikan tepat waktu.

\section{Malaksanakan Audit Internal Individu}

Laporan audit adalah produk kerja audit internal yang paling penting, kemampuan untuk merencanakan dan melakukan audit internal individu adalah persyaratan pengetahuan utama bagi auditor. Apakah seorang anggota staf auditor senior, anggota tim manajemen audit internal, harus memiliki pemahaman yang cukup untuk;
a. menilai risiko
b. merencanakan audit internal,
c. mengunjungi lokasi audit dan mulai perikatan,
d. menyiapkan kertas kerja yang mendokumentasikan kegiatan audit tersebut, dan
e. merangkum hasil dalam persiapan untuk laporan audit internal penutup.


Auditor internal harus memiliki pemahaman yang baik tentang Standar Internasional Praktik Profesional Audit Internal yang menguraikan langkah-langkah prosedur yang harus diikuti oleh auditor internal.

1. Sebagai bagian dari perencanaan audit, lakukan analisis risiko untuk mengidentifikasi potensi risiko pengendalian.

2. Berdasarkan hasil analisis risiko dan kendala lainnya, kembangkan rencana audit.

3. Menjadwalkan audit internal lebih awal dan mengalokasikan sumber daya.

4. Tinjau laporan audit dan kertas kerja sebelumnya yang mencakup area audit.

5. Kunjungi lokasi audit dan lakukan survei lapangan yang mencakup area audit yang direncanakan.

6. Berdasarkan kertas kerja dan survei lapangan yang telah ditetapkan, siapkan program audit.

7. Mempersiapkan dan menyampaikan surat penugasan untuk audit, dan berencana untuk memulai audit internal.

8. Mulai pekerjaan audit internal yang direncanakan.

9. Dokumentasikan proses dan lakukan prosedur audit yang direncanakan.

10. Mengembangkan lembar poin audit yang mencakup temuantemuan audit internal pendahuluan.

11. Lengkapi dokumentasi audit dan rangkumlah temuan audit potensial.

12. Lengkapi pekerjaan audit internal dan kaji temuan yang diajukan dengan audite.

Gambar 11.4 Ringkasan langkah-langkah proses audit internal Sumber : ( Moeller. R.R, 2016) 


\section{J. Simpulan}

Sebelum fungsi audit internal meluncurkan audit yang direncanakan, ia perlu memiliki beberapa peta untuk membangun sumber daya atau fungsi audit internal yang efektif. Kriteria yang memadai diperlukan untuk mengevaluasi tata kelola, manajemen risiko, dan pengendalian. Auditor Internal harus memastikan seberapa jauh manajemen telah menetapkan kriteria memadai untuk menilai apakah tujuan dan sasaran telah tercapai.

Jumlah dan tingkat staf yang diperlukan untuk berbagai audit tergantung pada evaluasi sifat dan kompleksitas proyek audit serta kemampuan auditor internal dan batasan waktu. Keterampilan auditor dan kebutuhan pengembangan harus dipertimbangkan dalam memilih personil untuk setiap tugas proyek audit. Setelah memutuskan segmen audit individu, bakat yang dibutuhkan untuk melakukan tugas audit harus ditentukan.

Audit internal selanjutnya melakukan survei lapangan untuk meningkatkan pemahaman tim audit yang ditugaskan tentang area yang akan ditinjau serta untuk membuat dokumentasi audit awal. Dalam hal itu, dokumentasi kertas kerja harus diambil dan diperbarui untuk audit internal yang baru dijadwalkan.

Untuk membantu mencapai tujuan konsistensi audit, auditor internal harus menggunakan apa yang disebut program audit untuk melakukan prosedur audit secara konsisten dan efektif untuk jenis audit serupa. Dalam beberapa situasi, program audit standar tidak akan berlaku. Misalnya, auditor internal meninjau pengendalian dalam entitas bisnis baru dengan beberapa karakteristik pengendalian yang unik.

Program audit yang dibangun dengan baik harus memandu auditor internal dalam proses pengumpulan bukti. Auditor 
internal akan menghadapi berbagai tingkat bukti audit dan harus berusaha merancang prosedur audit mereka untuk mencari dan mengandalkan bukti audit terbaik yang tersedia.

Memahami bagaimana melakukan audit internal benar-benar merupakan persyaratan utama auditor internal. Temuan-temuan potensial sebagai dasar memulai proses pembuatan laporan awal dan membantu memastikan bahwa fakta-fakta penting untuk mengembangkan laporan audit telah diperoleh.

\section{K. Contoh kasus}

Kasus dana haji mencuat setelah adanya laporan dari Pusat Pelaporan dan Analisis Transaksi Keuangan (PPATK) ketika melakukan audit PPATK, ada transaksi mencurigakan sebesar Rp. 230 miliar yang tidak jelas penggunaanya. Inilah yang mengindikasi dana haji ditempatkan di bank tanpa ada standarisasi penempatan yang jelas. Modus pencucian uang inilah yang disampaikan pihak PPATK kepada pihak KPK untuk ditindak lanjuti. KPK menyambut temuan dengan penyelidikan hampir setahun. Mulai Januari 2015, KPK melakukan penyelidikan atas dugaan penyimpangan dana haji tahun anggaran 2012 - 2013. Selain pengadaan barang dan jasa, KPK juga menyelidki biaya penyelengaraan ibadah Haji (BPIH) dan pihak - pihak yang diduga mendapatkan fasilitas haji.

\section{Solusi}

Bukti awal kecurangan bisa berasal dari pihak ekstern maupun intern perusahaan. Ketika melakukan peninjauan auditor internal harus memastikan bahwa pengendalian internal telah disusun dengan baik serta berfungsi dengan semestinya. Auditor internal harus memeriksa catatan atas laporan keuangan untuk memastikan bahwa hal-hal rutin terkait penyelenggaraan haji telah dijelaskan dalam catatan atas laporan keuangan. 


\section{Pertanyaan untuk didiskusikan}

1. Mengapa auditor internal harus menyiapkan program audit yang disesuaikan untuk memandu tinjauan untuk mengganti program audit standar?

2. Apakah pengendalian intern bisa dijadikan bukti ketika melakukan audit internal.?

3. Jelaskan jenis-jenis bukti yang kuat dan bagaimana cara memperoleh bukti tersebut!

\section{Soal Kasus}

Dari perspektif audit internal, Standar Internasional IIA untuk Praktik Profesional Audit Internal (Standar), mengenai Kecermatan Profesional (1220.A3) yang menyebutkan, “Auditor internal harus waspada terhadap risiko signifikan yang dapat memengaruhi tujuan, operasi, atau sumber daya.

Selain itu, Standar 2010 mengharuskan Kepala Audit Internal untuk mengembangkan rencana berbasis risiko dalam menentukan prioritas kegiatan audit internal, konsisten dengan tujuan organisasi.

Memahami risiko Lingkungan, Sosial, dan Tatakelola terkait pandemi yang saat ini sedang berkembang bukanlah hal yang sama sekali baru.

Buatlah program audit untuk memahami risiko lingkungan, sosial dan tatakelola!

\section{Daftar Pustaka}

Moeller, R. R. (2016). Brink's Modern Internal Auditing Eighth Edition A Common Body of Knowledge Published by John Wiley \& Sons, Inc., Hoboken, New Jersey.

BDO. (2015). Establishing An Effective Internal Audit Function. (October). 
Sarbanes. (2010a). Amendments to the Act. made by the DoddFrank Wall Street Reform and Consumer Protection Act (July 21, 2010).

COSO Internal Control. (2013). Integrated Framework Principles. 2013

Henning Kagermann, at all. (2008). Internal Audit Handbook. Springer-Verlag Berlin Heidelberg.

Kinney, W., Weber, C., Busch, J., \& Eckes, P. (2008). Internal Audit Handbook.

Auditors, I. (2017). Standar internasional praktik profesional audit internal (standar).

The Institute of Auditor internal s. (2016). Standar Internasional Untuk Praktek Profesional Auditing Internal.

IIARF. (2009). Internal Audit Capability Model (IA-CM): For the Public sector, 2009. 


\section{BAB 12}

LAPORAN HASIL AUDIT INTERNAL

\section{Capaian Pembelajaran}

1. Mahasiswa mampu memahami kerangka laporan hasil audit.

2. Mahasiswa mampu memahami tujuan dan jenis laporan hasil audit internal

3. Mahasiswa mampu memahami siklus pelaporan hasil audit internal.

\section{A. Pendahuluan}

Dalam membuat laporan hasil audit, internal auditor harus senantiasa berfikir, menimbang dan menganalisis seluruh bukti dan informasi yang diperoleh agar dapat membuat laporan yang baik. Jangan sampai kriteria antara "lengkap" dan "ringkas" seolah-olah bertentangan. Knowledge dan experience serta expertise sangat dibutuhkan untuk membuat laporan yang baik. Lengkap, juga bukan berarti detail. Ada hal-hal yang juga perlu dipertimbangkan agar tidak seolah-olah memberitahu hal-hal yang sudah diketahui sekalipun tidak disampaikan. Fungsi internal audit adalah untuk mengevaluasi proses kontrol, manajemen risiko dan tata kelola. Oleh karena itu, bagaimana kontrol dan pengelolaan risiko dan tata kelola sehubungan dengan biaya? Hal inilah yang harus dielaborasi dengan baik dalam laporan hasil audit.

Karena internal auditor adalah karyawan perusahaan, maka dia harus mengutamakan kepentingan perusahaan, termasuk kepentingan perusahaan untuk taat terhadap regulasi dan etika bisnis. Untuk membuat laporan hasil audit yang objektif, maka seorang internal auditor tidak boleh menggunakan tendensi pribadi dan juga tidak boleh terpengaruh secara psikologis atas masalah-masalah yang dijumpai dalam pemeriksaannya. 
Pemeriksaan juga harus dilakukan dengan baik agar dapat memperoleh dan mengetahui fakta, keadaan informasi yang relevan yang akan membantu dalam mendapatkan simpulan yang akan dituliskan atau dikomunikasikan dalam laporan audit.

\section{B. Tujuan dan Jenis Laporan Hasil Audit Internal}

Laporan hasil audit internal memiliki tujuan dasar untuk menggambarkan tujuan audit yang direncanakan dan untuk mengkomunikasikan hasil dan rekomendasi dari audit tersebut. Berdasarkan sifatnya, laporan hasil audit internal umumnya kritis dalam isinya dan cenderung menekankan hal-hal seperti kelemahan pengendalian internal. Meskipun sangat tepat untuk melaporkan bahwa audit internal meninjau beberapa area namun tidak menemukan masalah, hal ini menunjukkan ada kebutuhan untuk meninjau pendekatan penilaian risiko audit internal. Laporan hasil audit internal harus selalu memiliki empat komponen dasar:

a. Tujuan audit, waktu, dan ruang lingkup tinjauan. Laporan hasil audit harus meringkas tujuan tingkat tinggi dari tinjauan, di mana dan kapan tinjauan berlangsung, dan ruang lingkup tingkat tinggi dari audit internal. Pernyataan ruang lingkup, misalnya, dapat mengungkapkan bahwa audit dilakukan atas permintaan komite audit atau dimulai sebagai hasil dari kecurangan yang ditemukan.

b. Deskripsi temuan laporan hasil audit. Berdasarkan kondisi yang diamati dan ditemukan selama tinjauan, laporan hasil audit harus melibatkan pembacanya dengan menjelaskan hasil audit internal. $\mathrm{Di}$ sinilah laporan tersebut menggambarkan apa yang salah dengan kondisi yang ditemukan, serta mengapa itu salah. Istilah yang salah di sini termasuk kelemahan pengendalian internal, pelanggaran 
prosedur perusahaan, atau berbagai masalah audit internal lainnya.

c. Saran untuk tindakan korektif. Laporan hasil audit harus mencakup rekomendasi, berdasarkan temuan audit, untuk memperbaiki kondisi yang diamati dan penyebabnya. Tujuan rekomendasi adalah memperbaiki kondisi yang diamati serta meningkatkan operasi.

d. Dokumentasi rencana dan klarifikasi pandangan pihak yang diaudit.

Pihak yang diaudit mungkin ingin menyatakan keadaan mitigasi atau memberikan klarifikasi untuk setiap masalah yang dilaporkan dalam ketidaksepakatan. Bergantung pada format laporan, ini sering merupakan tempat di mana pihak yang diaudit dapat secara formal mengajukan tanggapan terhadap temuan audit internal dan menyatakan rencana untuk tindakan korektif dalam menanggapi temuan dan rekomendasi audit tersebut.

Laporan hasil audit harus bersifat membangun, karena auditor internal bukan orang yang langsung menindaklanjuti temuan, maka harus bisa mempengaruhi customer audits agar mau dan termotivasi untuk melakukan tindaklanjut. Jangan sampai kalimat-kalimat dalam laporan yang disampaikan berisi kata-kata yang malah membuat audits customers menjadi merasa tidak dihargai atau bahkan kalimat-kalimat yang digunakan mengindikasikan laporan audit berisi negative list. Begitu hasil audit disampaikan dengan kata-kata yang tidak memotivasi untuk membangun, maka bersiaplah bahwa auditor internal akan menemukan hal yang sama pada periode audit berikutnya.

Dalam melakukan audit, seorang auditor harus menyampaikan secara berimbang temuan yang diperolehnya 
berdasarkan fakta atau hasil analisisnya. Hal yang baik juga merupakan temuan, sedangkan hal yang dianggap kurang baik atau penyimpangan juga harus diukur dampaknya. Ukuran dampak ini juga harus jelas dan menggunakan pertimbangan profesional atau menggunakan referensi risk tolerance atau risk appetite perusahaan. Hal ini akan semakin mendukung untuk membuat kalimat temuan yang lebih konstruktif. Ukuran ini juga menentukan tone dari laporan yang dihasilkan. Menggunakan kata yang baik "healing words" akan lebih baik sekalipun harus tetap mempertahankan ketegasan.

\section{Laporan Hasil Audit yang Diterbitkan}

Dengan SOx, anggota komite audit, manajemen senior, memiliki akses ke salinan lengkap dari semua laporan hasil audit. Komite audit bertanggung jawab untuk menerima dan memahami semua temuan audit yang dilaporkan. Temuan pengendalian internal harus dijelaskan dengan rinci dalam laporan hasil audit internal.

\section{Format Laporan Hasil Audit yang Diterbitkan}

Laporan hasil audit adalah dokumen laporan formal yang menguraikan temuan dan rekomendasi audit internal berikut empat tujuan yang telah dibahas sebelumnya. Bagi auditor internal, laporan audit adalah merupakan hasil yang sangat berharga karena laporan tersebut merupakan hasil nyata yang akan digunakan oleh audite dan stakeholders sebagai informasi atau panduan untuk pengambilan keputusan.

Pengguna internal dari laporan audit sangat beragam dan tergantung ukuran dari perusahaan. Untuk perusahaan yang tergolong big company maka pengguna internal terdiri 
dari: Board of Directors, Audit Committee, Line of Management (Division \& Region) dan Unit Customer Audit atau Operational Unit serta Internal Audit Division.

Pengguna eksternal biasanya terdiri dari external auditor dan industry regulator. Secara insidentil, pengguna lainnya bisa berupa institusi investigator jaksa atau pengadilan. Beragamnya pengguna laporan hasil audit, maka akan merepotkan dan menjadi pekerjaan yang rumit bila auditor internal membuat berjenis-jenis laporan hasil audit. Sehingga, pengaturan yang dilakukan adalah menetapkan standar kualitas laporannya.

Dalam standar profesi yang dipublikasi oleh The IIA (the Standard: Communication) disebutkan bahwa laporan harus memenuhi kriteria: Clear, Concise, Complete, Constructive, Accurate, Objective dan Timely.

\section{Laporan audit harus Clear}

Dokumen Practice Advisory juga sangat menganjurkan untuk menulis kalimat menggunakan aturan-aturan atau "tata krama" penulisan yang baku dengan pola kalimat terstruktur dimulai dengan Subjek, Predikat, Objek dan Keterangan serta dalam bentuk kalimat aktif

\section{Laporan audit harus Concise}

Untuk membuat laporan menjadi ringkas, harus ada proses pemilihan point of view yang tepat dari setiap isu yang akan disampaikan dalam laporan hasil audit. Tentu pemilihan point of view ini harus selaras dengan fact findings dan konteks atau substansi dari hasil/temuan audit. Biasanya, point of view yang sering digunakan adalah root causes. Ringkas itu bukan diukur dari jumlah 
halaman akan tetapi dari efektifitas cara atau pola penyampaian substansi pesan dari hal-hal yang dilaporkan.

\section{Laporan audit harus Complete}

Sering terjadi, karena sangat lengkap malah mubajir dan tidak ringkas. Yang paling aneh, terasa lengkap tapi sesungguhnya tidak nyambung dan malah membuat tidak jelas, alias kabur dari substansi yang hendak disampaikan.

4. Laporan audit harus Constructive

Apabila ada tendensi karyawan tidak perduli dengan pekerjaannya. Maka seorang auditor, mungkin akan lebih baik tidak hanya meyampaikan isu karyawan tersebut, akan tetapi juga menyampaikan pihak lain yang tidak melakukan coaching sehubungan dengan kinerja karyawan yang tidak perduli tersebut.Dengan cara penyampaian tersebut, maka pihak-pihak yang menjadi "objek" findings akan sama-sama terlibat tanggung jawab..

\section{Laporan audit harus Accurate}

Komunikasi yang akurat bebas dari kesalahan dan distorsi dan setia pada fakta yang mendasarinya. Sehingga keakuratan sangat menuntut sikap kehati-hatian dalam penugasan dan juga dalam penyampaian fakta-fakta yang diperoleh selama penugasan audit. Tingkat akurasi juga sangat dipengaruhi oleh kemampuan internal auditor dalam mengidentifikasi root causes, impact maupun potential impact 


\section{Laporan audit harus Objective}

Objektif itu tidak memihak dan berada pada posisi yang pas dan diterima pada semua pihak. Oleh karena itu, supaya objektif, maka internal auditor juga tidak boleh berada pada situasi yang dapat merusak (impair) kemampuan untuk membuat pertimbangan profesional yang objektif

Terkadang, dalam banyak kejadian, objektifitas ini sering tidak terpenuhi karena pengaruh kompetensi atau kurangnya daya analisis terhadap fakta, kondisi atau keadaan saat dilakukan audit. Di samping hal tersebut, tidak dilakukan diskusi atau klarifikasi atas findings dengan baik juga bisa mengakibatkan internal audit menjadi tidak objektif.

\section{Laporan audit harus Timely}

Oleh karena tidak ada yang bisa mengukur kapan waktu yang tepat, maka biasanya ukurannya adalah dengan membuat policy yang mengatur tentang turn arround time yang dihitung setelah internal auditor selesai melakukan exit meeting dengan customer audits dan tiba di home base. Karena laporan hasil audit terutama ditujukan untuk pengambilan keputusan atau sebagai laporan untuk menginformasikan. Jadi arti dari "timely" yang tepat dalam hal ini adalah: secepatnya.

Seluruh kriteria tersebut juga dijelaskan pada dokumen Practice Advisory dengan baik dan detail. Tujuh kriteria kualitas laporan tersebut sangat padat makna dan substansi 
dan kalau hanya diamati sepintas akan terasa ada yang saling berlawanan. Betapa perlunya pemahaman membuat laporan yang: Jelas, Lengkap dan Ringkas sekaligus Akurat.

Menulis adalah sesuatu yang mudah, akan tetapi membuat orang untuk memahami maksud kita melalui sebuah tulisan yang nenggambarkan rekonstruksi fakta, penyebab fakta dan kondisi di lapangan akan sangat membutuhkan keahlian. Sifat obyektivtas dalam hal ini auditor internsangat diuji ketidakberpihakan dan menjauhkan diri dari konflik kepentingan. Karena dalam practice advisory disebutkan bahwa harus: free from distortion and must be mindful and free of conflicts.

\section{(https://ionnygultom.wordpress.com, 2016)}

Secara detail, practice advisory juga mengharuskan penggunaan kata yang tepat dan pengaturan kalimat yang sistematis dengan mendahulukan ide utama, ide pendukung dan tambahan. Menurut standar the IIA dalam penjabarannya di practice advisory sangat menganjurkan menggunakan bentuk "kalimat aktif". Penggunaan kata harus menggunakan pilihan kata yang tepat sesuai kondisi, fakta atau situasinya. Disini akan sering terjadi kesulitan apabila tidak ada kata atau susah untuk mencari kata yang tepat sehingga: mau tidak mau harus menyampaikannya dengan beberapa kata yang menjelaskan.

Jadi, intinya adalah, semua kriteria yang disebutkan dalam standar, memang mempunyai falsafah yang bertujuan untuk memudahkan penulis laporan agar laporan itu berkualitas mencapai tujuan. 
Laporan hasil audit internal harus selalu memiliki penilaian yang cukup umum tentang kecukupan keseluruhan pengendalian atau masalah lain di bidang yang ditinjau. Sebagai contoh, pernyataan opini dapat menggunakan salah satu dari contoh berikut:

a. "Kami mendapati pengendalian di area yang ditinjau memadai kecuali untuk. . "

b. "Kami mendapati bahwa sebagian besar pengendalian baik dan beroperasi saat diinstal. . "

c. "Kami mengidentifikasi masalah pengendalian yang signifikan di area yang ditinjau. Temuan kami. .... "

Laporan hasil audit internal sering mengikuti salah satu dari beberapa pendekatan umum. Tergantung pada jenis perusahaan, gaya manajemen secara keseluruhan, keterampilan staf audit internal, dan banyak faktor lainnya, masing-masing format laporan hasil audit yang diuraikan memiliki kelebihan dan kekurangannya masing-masing. Audit internal ingin mengkomunikasikan apa yang dilakukannya, apa yang ditemukannya, dan apa yang perlu diperbaiki dengan cara yang akan menarik perhatian manajer kunci di perusahaan. Tanpa informasi yang cukup, pembaca mungkin tidak tahu apakah ada masalah serius atau masalah lain yang memerlukan tindakan mengingat format laporan yang dirangkum. Laporan hasil audit internal yang efektif harus selalu mencakup elemen-elemen kunci berikut:

a. Ringkasan singkat dari laporan hasil audit keseluruhan. Laporan harus dimulai dengan elemen-elemen utama audit yang dilakukan, membahas masalah-masalah kritis, dan kemudian merangkum detailnya. Ini akan 
menarik perhatian pembaca manajemen sebelum perlu masuk ke detail laporan.

b. Pesan utama dari laporan audit. Laporan tersebut harus membahas hasil pekerjaan audit, risiko terkait, dan masalah manajemen untuk dipertimbangkan. Ini harus menyoroti mengapa pembaca harus memperhatikan rekomendasi auditor internal serta risiko tidak mengikuti rekomendasi tersebut.

c. Elemen-elemen dari temuan audit. Bergantung pada ruang lingkup dan sifat audit, temuannya dapat mencakup banyak detail. Namun, laporan hasil audit yang efektif harus merangkum temuannya menggunakan teknik seperti grafik dan grafik ilustrasi untuk membantu menyampaikan pesan.

d. Kalimat dan kata-kata yang singkat dan sederhana yang dimengerti oleh audiens.

Pendekatan untuk mengembangkan dan menerbitkan laporan hasil audit internal sangat tergantung pada sifat dan ruang lingkup audit dan menyajikan kepada departemen audit internal, komite audit, dan manajemen dengan berbagai alternatif.

Beberapa laporan hasil audit internal berupaya menyajikan banyak informasi tentang bidang kegiatan yang ditinjau. Tujuannya adalah untuk menyediakan sumber referensi yang mendalam kepada pengguna laporan. Informasi dapat bersifat historis atau berkaitan dengan situasi saat ini. Ini dapat mencakup praktik operasional dan output operasional atau berurusan dengan informasi keuangan. 
Laporan hasil audit internal kadang-kadang masuk ke detail yang cukup tebal tentang hasil dari berbagai upaya audit. Meskipun cakupan di sini mungkin terlihat mengesankan, diragukan apakah banyak detail yang menggambarkan temuan audit bermanfaat. Dengan laporan hasil audit yang sangat tebal, pembaca dapat dimatikan karena kehilangan materi penting. Laporan tidak boleh informasi lebih banyak daripada yang dibutuhkan. Laporan hasil audit harus hanya memberikan informasi yang diperlukan dan memadai tentang temuan audit dan memungkinkan pembaca untuk memahami masalah terperinci yang terlibat.

Dari sisi yang lain, departemen audit internal hanya merilis laporan yang dirangkum yang hanya memberikan informasi bahwa audit internal telah mengkaji bidang sesuatu yang umum dan biasanya tidak menemukan pengecualian pengendalian yang signifikan. Gaya laporan yang sama ini sering menyebutkan bahwa pengecualian pengendalian ditemukan dan diperbaiki, tanpa dirinci pengeualian tersebut. Laporan-laporan ini menyatakan bahwa audit internal telah meninjau suatu area dan menemukan beberapa "item minor," yang tidak termasuk dalam laporan. Bentuk laporan yang terlalu singkat tidak efektif untuk sebagian besar kebutuhan pelaporan hasil audit internal. Selain itu, laporan yang dirangkum dapat membahayakan pembaca komite audit dengan mengabaikan kelemahan pengendalian internal yang berpotensi signifikan, dan dengan tidak memberikan perincian yang diperlukan berdasarkan aturan SOx. 
Format laporan yang lebih umum dan yang terbaik adalah format yang hanya berfokus pada isu-isu penting yang memiliki potensi penting terkait dengan kelemahan pengendalian internal, kebijakan, pendekatan operasional, pemanfaatan sumber daya, kinerja karyawan, dan hasil yang dicapai. Semakin banyak manajer perusahaan senior yang tertarik terutama pada masalah yang sifatnya dan cakupannya demikian, dan mereka biasanya ingin diberi informasi dan diberi kesempatan untuk berkontribusi pada solusi. Keuntungan dari fokus pada masalah yang signifikan manajer senior dapat memperoleh informasi yang mereka butuhkan tanpa mengarungi detail yang berlebihan.

Format laporan aktual dan metode penyajian akan bervariasi dari satu perusahaan ke perusahaan lain. Tampilan 18.2 menunjukkan contoh laporan singkat tetapi positif. Meskipun ini adalah laporan format memo dan panjangnya hanya satu halaman, laporan beberapa halaman harus mengikuti gaya umum yang sama.

\section{Elemen Temuan Laporan Hasil Audit}

Selama peninjauan, auditor internal melaksanakan audit mungkin menghadapi kelemahan pengendalian internal di beberapa area yang ditinjau, harus diuraikan dalam program audit. Program audit tersebut seharusnya membantu mengidentifikasi pengecualian serta pengamatan audit internal lainnya yang menjadi subjek dari temuan laporan hasil audit.

Auditor biasanya akan menemukan sejumlah besar dan beragam pengecualian dalam pelaksanaan ulasan. Beberapa di antaranya mungkin relatif penting. Seperti penemuan 
sejumlah besar voucher yang diajukan untuk pembayaran tetapi tidak memiliki tanda tangan persetujuan yang tepat. Yang lain mungkin relatif kecil seperti penemuan seorang karyawan yang melaporkan $\mathrm{Rp} 50.000$,- untuk biaya makan ketika kebijakan mensyaratkan bahwa biaya tersebut harus kurang dari Rp 50.000,-, sehingga melanggar kebijakan. Dalam kasus seperti itu, audit internal mungkin pertimbangkan untuk melaporkannya melalui rangkuman yang mencakup kondisi keseluruhan.

Temuan laporan hasil audit disajikan dalam format yang umum memungkinkan pembaca laporan untuk memahami masalah dengan mudah. Temuan audit yang disusun dengan buruk sering membuat pembaca laporan mempertanyakan apa masalahnya dan mengapa mereka harus khawatir. Laporan hasil audit yang baik harus berisi hal-hal berikut:

a. Pernyataan kondisi. Kalimat pertama dalam laporan harus merangkum hasil tinjauan audit internal dari bidang yang menjadi perhatian. Ini dapat memberikan perbandingan "kondisi" dengan "yang seharusnya." Tujuannya adalah untuk menarik perhatian pembaca laporan.

b. Kriteria audit internal untuk menyajikan temuan. Temuan audit harus selalu memiliki kriteria, atau pernyataan tentang apa yang harus digunakan dalam menilai pernyataan kondisi. Tanpa kriteria yang kuat tidak akan ada temuan audit. Kriteria dapat berupa kebijakan, prosedur, dan standar suatu perusahaan. Dalam beberapa kasus, audit internal harus mengembangkan kriteria sendiri. Dalam audit 
efektivitas beberapa prosedu. Auditor internal harus mempertimbangkan hal-hal berikut:

1) Kriteria ekstrem. Meskipun biasanya terlalu ekstrem ini dapat menyebabkan audit internal menyatakan bahwa beberapa kondisi yang diamati "hampir sama buruknya dengan dengan yang telah ditemukan.

2) Kriteria yang sebanding. Perbandingan dapat dibuat antara operasi yang serupa untuk menentukan keberhasilan atau kurangnya keberhasilan dan penyebab perbedaan. Laporan tersebut dapat membandingkan kondisi yang ditemukan dengan kondisi rata-rata atau khas di seluruh perusahaan.

3) Kriteria elemen. Ukuran kinerja yang dilaporkan harus dipecah berdasarkan fungsional, organisasi, atau oleh unsur-unsur biaya yang terkait dengan kegiatan tertentu.

4) Kriteria keahlian. Dalam beberapa kasus, audit internal mungkin bermanfaat untuk mengandalkan ahli lain untuk mengevaluasi suatu kegiatan.

c. Pengaruh temuan yang dilaporkan. Audit internal harus selalu mempertimbangkan pertanyaan "Seberapa penting?" Ketika memutuskan akan memasukkan item dalam laporan hasil audit. Setelah keputusan dibuat untuk memasukkannya sebagai temuan dalam laporan hasil audit, efek dari kondisi yang dilaporkan harus dikomunikasikan. Temuan yang akan menghasilkan penghematan moneter atau yang mempengaruhi operasi 
perusahaan dan pencapaian tujuan selalu menjadi minat khusus bagi manajemen.

d. Penyebab penyimpangan. Alasan penyimpangan yang ditemukan dari persyaratan, standar, atau kebijakan harus dijelaskan secara singkat. Identifikasi penyebab untuk kondisi tersebut memberikan dasar untuk mengambil tindakan manajemen yang diperlukan.

e. Rekomendasi. Temuan laporan hasil audit harus diakhiri dengan merekomendasikan tindakan korektif yang sesuai. Sebuah rekomendasi dapat menjadi peringatan sederhana untuk memperbaiki sesuatu yang disarankan.

\section{Siklus Pelaporan Hasil Audit Internal}

Dimulai pada tahap awal audit internal mengembangkan kerangka kerja untuk laporan akhir. Informasi dan statistik tentang area yang akan diaudit dapat dikumpulkan selama tahap survei dan dimasukkan dalam kertas kerja. Ini akan memastikan bahwa informasi yang diperlukan diperoleh di awal audit, dan itu akan mencegah keterlambatan dalam proses penulisan laporan akhir.

Ketika temuan audit dikembangkan dan diselesaikan, temuan tersebut dapat dimasukkan ke dalam bagian laporan yang tepat bersama dengan komentar dari pihak yang diaudit. Laporan hasil audit yang lengkap sangat penting dalam keseluruhan proses audit internal untuk mengevaluasi dan mengomentari kecukupan pengendalian internal. Kemungkinan penyebab temuan audit juga harus didiskusikan dengan audite selain untuk mencari informasi tambahan diskusi juga merupakan sarana audite untuk membuktikan atau menyangkal kondisi laporan hasil audit. Membahas temuan dengan personil perusahaan di tingkat staf 
membantu untuk mendapatkan kesepakatan dan mendorong tindakan implementasi. Ketika kesepakatan tercapai, audit internal mungkin dapat membatasi jumlah detail yangmasuk dalam laporan hasil audit, sehingga mempersingkat laporan hasil audit.

\section{Menyiapkan dan Menyampaikan Laporan Hasil Audit}

Setelah pekerjaan audit selesai dan auditor internal telah membahas temuan audit yang diusulkan dengan audite, draft laporan hasil audit umumnya harus disiapkan untuk dipresentasikan kepada manajemen. Draf tersebut kemudian dikirim ke manajer area yang diaudit. Draf laporan akhir ini biasanya disajikan sebagai peluang terakhir bagi audite untuk membaca dan memahami pesan dan isi laporan hasil audit yang dikeluarkan. Auditor internal kemudian menggabungkan respons audite pada laporan hasil audit final.

Rapat penutup membahas draft laporan adalah langkah penting untuk memvalidasi kecukupan dan keakuratan hasil audit internal yang dilaporkan dan rekomendasi sebelum laporan hasil audit akhir. Validasi pekerjaan audit bermanfaat untuk

a. Pertama, ini memberikan pemeriksaan silang pada akurasi, kelengkapan, dan kualitas pekerjaan audit. Fakta-fakta penting mungkin telah diabaikan atau ditafsirkan secara keliru. Mungkin juga ada faktor-faktor lain yang mempengaruhi beberapa hal tertentu yang hanya diketahui oleh orang-orang tertentu.

b. Kedua adalah membantu mempromosikan hubungan kemitraan dengan manajemen lokal yang akan 
menciptakan semangat kerja sama dan komitmen untuk mencari solusi yang memadai.

\section{Tindak Lanjut Laporan Hasil Audit dan Peringkasan}

Setelah manajemen mengirimkan tanggapan laporan hasil auditnya, auditor internal harus menggabungkan tanggapan ini dengan rancangan temuan dan rekomendasi untuk mengeluarkan laporan hasil audit akhir yang ditujukan kepada manajemen audite, dengan salinan ke komite audit dan pejabat lain yang sesuai. Setelah laporan hasil audit final dikeluarkan, audit internal selanjutnya harus menjadwalkan tindak lanjut review untuk memastikan bahwa tindakan yang diperlukan berdasarkan audit benar-benar diambil. Tindak lanjut atas rekomendasi bisa didampingi oleh auditor agar audite merasa nyaman selama melaksanakan tindak lanjut.

\section{E. Simpulam}

Laporan hasil audit harus bersifat membangun, karena auditor internal bukan orang yang langsung menindaklanjuti temuan, maka harus bisa mempengaruhi customer audits agar mau dan termotivasi untuk melakukan "pembangunan" itu melalui penyampaian temuan yang jelas, dan bisa tergambar jenis "bangunan" yang harus dibangun.

Dalam standar profesi yang dipublikasi oleh The IIA (the Standard: Communication) disebutkan bahwa laporan harus memenuhi kriteria: Clear, Concise, Complete, Constructive, Accurate, Objective dan Timely.

Temuan audit disajikan dalam format yang umum memungkinkan pembaca laporan untuk memahami masalah dengan mudah. Temuan harus membahas prosedur dan hasil dari prosedur tersebut. 
Rapat penutup membahas draft laporan adalah langkah penting untuk memvalidasi kecukupan dan keakuratan hasil audit internal yang dilaporkan dan rekomendasi sebelum laporan hasil audit akhir.

\section{F. Contoh Kasus Laporan Hasil Audit}

Standar the IIA dalam penjabarannya di Practice Advisory sangat menganjurkan menggunakan bentuk "kalimat aktif". Pelajaran masa lalu lengkap dengan Subjek, Predikat, Objek dan Keterangan kembali diingatkan dalam standard. Standard adalah berarti sesuatu yang baku dan tidak perlu dipertentangkan lagi. Harus menggunakan pilihan kata yang tepat sesuai kondisi, fakta atau situasinya.

\section{Solusi}

Begitu juga untuk temuan audit sebaiknya menggunakan kalimat yang positif. Contoh kalimat negatif "Departemen gagal dalam beberapa operasi program pelatihannya". Kalimat positif "Ada beberapa peluang untuk memperkuat pengendalian dalam operasi program pelatihan"

\section{Pertanyaan untuk didiskusikan}

1. Jelaskan yang dimaksud dengan laporan audit harus memenuhi kreteria Clear, Concise, Complete, Constructive, Accurate, Objective dan Timely!

2. Mengapa laporan temuan audit harus mengungkapkan kondisi, kreteria, dampak, penyebab, dan rekomendasi?

\section{Soal Kasus}

Pertumbuhan yang besar tidak selamanya baik dan harus menjadi concern auditor dan melakukan analisis yang baik. Banyak kasus yang dramatis terjadi pada industri perbankan karena integritas oknum pegawai yang tidak terkontrol. Disisi lain, jumlah target yang tinggi juga dapat memicu unit operasional tertekan dan menjadi loose control dan menjadi tidak rasional dalam mengkalkulasi risiko.

Mengapa target yang tinggi dapat memicu loose control? 
Daftar Pustaka

Moeller.R.R. R. R. (2016). Brink's Modern Internal Auditing Eighth Edition A Common Body of Knowledge Published by John Wiley \& Sons, Inc., Hoboken, New Jersey.

https://jonnygultom.wordpress.com.

(2016).

https://ionnyqultom.wordpress.com /2016/03/19/failures/. 


\section{BAB 13}

\section{PROGRAM ETIKA DAN WHISTLEBLOWER}

\section{Capaian Pembelajaran}

1. Mahasiswa mampu memahami etika, kepatuhan, dan tata kelola perusahaan.

2. Mahasiswa mampu memahami lingkungan risiko etika.

3. Mahasiswa mampu meringkas hasil survei etika.

4. Mahasiswa mampu membedakan fungsi whistleblower dan hotline.

5. Mahasiswa mampu memahami cara mengaudit fungsi etika perusahaan.

\section{A. Pendahuluan}

Whistleblower adalah orang yang memaparkan informasi terkait aktivitas rahasia yang dianggap ilegal, tidak etis, atau tidak benar dalam organisasi swasta atau publik. Informasi dugaan kesalahan dapat digolongkan dalam banyak cara: pelanggaran kebijakan, peraturan perusahaan, hukum, peraturan, atau ancaman terhadap kepentingan publik, keamanan nasional, serta penipuan, dan korupsi.

Setiap kali ada pertanyaan tentang transaksi yang dipertanyakan atau penipuan dalam operasi, respons manajemen hampir selalu meminta auditor internal untuk menyelidiki masalah tersebut. Karena standar profesional auditor internal yang kuat, didukung oleh kode etik profesi yang baik, auditor internal harus menjadi pemimpin yang beretika di perusahaan.

Etika dan pedoman perilaku di seluruh perusahaan memiliki peran yang jauh lebih besar di perusahaan saat ini. Beberapa 
perusahaan membangun etik dan pedoman perilaku tentang komitmen mereka terhadap etika. Namun, sejak diluncurkannya revisi kerangka kerja komite pengawasan organisasi, serta peraturan Sarbanes-Oxley Act (SOx), menciptakan penekanan hampir di seluruh dunia tentang pentingnya membangun lingkungan etis di seluruh perusahaan. Selain membangun lingkungan etis untuk semua pemangku kepentingan perusahaan, juga mengembangkan program whistleblower.

Program whistleblower adalah fasilitas penting bagi perusahaan secara keseluruhan. Konsepnya adalah setiap karyawan atau pemangku kepentingan boleh melaporan pelanggaran etik kepada manajemen senior tanpa takut dikriminalisasi. Program Whistleblower telah menjadi standar dalam banyak aturan hukum diperusahaan.

Auditor internal perlu memahami bagaimana whistleblower harus diterapkan pada unit keseluruhan perusahaan. Program etika yang efektif adalah alat tata kelola dan kepatuhan yang penting bagi seluruh perusahaan.

\section{B. Etika, Kepatuhan, dan Tata Kelola Perusahaan}

Banyak kegagalan bisnis sering terjadi karena perilaku tidak etis oleh manajer bisnis di semua tingkatan. Secara historis, kegagalan semacam itu bukan hal baru. Penyimpangan etika saat ini sering tampak berbeda, karena akses ke informasi secara luas yang membuat banyak orang terluka karena kecurangan dalam investasi pasar saham, rekening pensiun, dan kepentingan finansial lainnya. Masyarakat mendorong pelaku bisnis mematuhi peraturan dan regulasi serta peningkatan minat dalam etika bisnis, kode etik, dan masalah tata kelola perusahaan. 
Standar profesional audit internal menjadikan kode etik komponen yang menonjol, dan banyak auditor internal terlibat dengan meninjau dan membantu meningkatkan program etika perusahaan. Perusahaan bisa meluncurkan dan mengimplementasikan program etika dan pedoman perilaku diseluruh unit perusahaan. Perusahaan dari semua ukuran dan bidang bisnis saat ini harus membangun fungsi etika yang efektif, Meskipun program etika penting, sebuah perusahaan tidak dapat mengklaim telah menerapkannya hanya dengan menerbitkan kode perilaku bisnis dan menginstruksikan semua karyawan untuk membacanya. Program etika yang efektif membutuhkan komitmen formal antara perusahaan dan karyawan untuk melakukan hal yang benar.

Suatu perusahaan harus mempertimbangkan untuk meluncurkan program etika yang berlaku untuk semua pemangku kepentingan di seluruh operasinya. Sementara penekanannya mungkin sedikit berbeda di berbagai tingkatan, semua harus menyadari nilai-nilai perusahaan dan misi keseluruhan.

\section{Langkah Pertama Membangun Etika: Mengembangkan Pernyataan Misi}

Setiap perusahaan, tidak peduli ukurannya, harus memiliki pernyataan misi untuk menggambarkan tujuan dan nilai keseluruhannya. Pernyataan misi harus menjadi sumber arahan agar karyawan, pelanggan, pemegang saham, dan pemangku kepentingan lainnya tahu apa yang diperjuangkan perusahaan. Pernyataan misi yang efektif sangat penting untuk mempromosikan etika organisasi yang kuat dan tata kelola perusahaan yang baik. Pernyataan misi yang efektif dapat menjadi 
aset besar bagi perusahaan, yang memungkinkannya untuk mencapai tujuan organisasi dengan lebih baik.

Pernyataan misi yang baik harus membuat pernyataan positif tentang perusahaan dan bisa menginspirasi para pemangku kepentingan perusahaan untuk memanfaatkan energi, semangat, dan komitmen mereka untuk mencapai tujuan dan sasaran.

Setelah perusahaan mengembangkan pernyataan misi harus diluncurkan kepada semua anggota perusahaan dengan tingkat publisitas yang baik. Menggunakan pendekatan at-thetop, manajer senior harus menjelaskan alasan untuk pernyataan misi dan mengapa penting bagi perusahaan. Pernyataan misi harus diposting di papan iklan, dalam laporan tahunan, di beranda perusahaan, dan di tempat lain untuk mendorong semua pemangku kepentingan memahami dan menerimanya. Pernyataan misi, bagaimanapun, seharusnya tidak berdiri sendiri; serangkaian langkah kunci lainnya diperlukan untuk membangun fungsi etika dan kepatuhan yang efektif.

\section{Memahami Lingkungan Risiko Etika}

Hampir setiap perusahaan menghadapi campuran risiko yang membatasi operasi bisnis, pertumbuhan, profitabilitas, atau bidang lainnya. Memahami lingkungan risiko suatu perusahaan harus selalu menjadi langkah pertama untuk meluncurkan program etika yang efektif. Program etika dapat membantu melindungi perusahaan dari berbagai risiko operasional dan bisnis lainnya. Survei etika adalah cara yang sangat baik untuk memahami sikap perusahaan dan merupakan bantuan untuk mendukung proses tata kelola perusahaan. 


\section{Temuan Terkait Etika dari Audit Sebelumnya atau Audit Khusus}

Jika auditor internal telah menyelesaikan audit operasional dan keuangan yang terkait dengan kepatuhan, dapat melakukan pemeriksaan ulang kertas kerja dan temuan-temuan laporan audit atau bahkan tanggapan laporan audit dapat memberikan wawasan tentang sikap etis perusahaan secara keseluruhan. Temuan yang konsisten yang mencakup pelanggaran "kecil" dapat menunjukkan tren keseluruhan dalam sikap etis.

Tim audit mungkin telah memutuskan bahwa masalahnya "terlalu kecil" untuk dimasukkan dalam ringkasan laporan audit akhir. Beberapa temuan "minor" mungkin tidak menunjuk pada pelanggaran etika karena tidak tercantum dalam penyataan etika hal ini menunjukkan bahwa kode etik perlu direvisi.

Peraturan biaya perjalanan dilaporkan melalui kuitansi, termasuk tarif tol $\mathrm{Rp} 3.500$,-. Orang lain mungkin merasa bahwa aturan yang mensyaratkan kuitansi seminimal itu tidak menambah nilai, sebaiknya laporan pengeluaran sebesar Rp 3.500 diajukan tanpa kuitansi dan disetujui tanpa tanda terima. Dari perspektif audit internal, apakah situasi ini merupakan pelanggaran etika bagi perusahaan? Pada satu tingkat, jawabannya mungkin ya, karena aturan adalah aturan.

\section{Survei Sikap Etika Karyawan dan Stakeholder.}

Survei yang dilakukan dengan benar terhadap karyawan, pegawai, dan pemangku kepentingan dapat menjadi cara terbaik untuk menilai sikap etis perusahaan. Survei sikap 
etika akan mencakup beberapa pertanyaan umum, masingmasing kelompok juga akan menerima pertanyaan spesifik yang diarahkan pada tanggung jawab mereka.

Menyusun survei pengumpulan fakta yang menerima tingkat respons tinggi tidak pernah mudah, dan penggunaan bantuan khusus harus dipertimbangkan. Survei harus terdiri dari banyak jenis pertanyaan di mana orang yang mengisi survei dapat memberikan jawaban sesingkat yang mereka inginkan. Respons tanpa akhir ini membuat lebih sulit untuk mengkompilasi hasil, tetapi informasi yang menarik dan berharga dapat dipertahankan.

Salah satu dari pendekatan survei memungkinkan audit internal Persyaratan utama dari jenis survei ini adalah survei harus seanonim mungkin. Survei harus dikirim langsung karyawan bersama dengan surat pengantar dari chief executive offcer (CEO) yang menjelaskan tujuan survei. Meringkas hasil survei dapat menjadi tantangan utama jika responden telah memberikan tanggapan bentuk bebas. Audit internal atau staf etika bertanggung jawab untuk menyiapkan ringkasan hasil survei, dengan tujuan meninjau hasilnya dengan komite audit dan manajemen senior. Untuk alasan kerahasiaan, responden tidak akan menerima laporan ringkasan ini. Survei-survei ini akan memberikan wawasan umum kepada manajemen tentang suasana etika keseluruhan di perusahaan mereka. Informasi hasil survei akan mendukung praktik tata kelola perusahaan dengan menyoroti bidangbidang di mana perbaikan diperlukan. 


\section{E. Meringkas Hasil Survei Etika}

Hasil survei sikap etika dapat memberikan beberapa jaminan bahwa segala sesuatu tampak cukup baik di seluruh perusahaan. Namun, lebih sering, hasil survei mengangkat beberapa tanda yang meresahkan, mulai dari penyimpangan kepatuhan yang kecil namun terus-menerus, hingga vendor yang disurvei yang mengklaim taktik negosiasi berat, hingga karyawan yang menyatakan bahwa mereka telah diminta untuk melanggar peraturan. Sehingga timbul pertanyaan dari hasil seperti itu adalah apakah mereka mewakili pengecualian yang mengganggu atau ujung dari masalah etika yang jauh lebih besar. Pada titik ini, auditor internal harus bertemu dengan manajemen senior untuk mengembangkan beberapa langkah selanjutnya.

Berdasarkan potensi bahaya yang mengganggu dari survei, mungkin yang terbaik adalah memperluas proses survei. Juga, kekhawatiran dari survei awal tersebut mungkin menunjukkan perlunya memperluas penilaian ke kelompok-kelompok seperti pelanggan, agen, atau vendor. Jika hasil survei berakhir dengan pesan yang tidak meyakinkan, langkah lain yang sesuai adalah membuat serangkaian sesi kelompok fokus. Kelompok kecil karyawan dan pemangku kepentingan akan dipilih secara acak dan diminta untuk bertemu untuk membahas persepsi mereka tentang nilai-nilai etika perusahaan. Dengan penekanan kuat bahwa setiap tanggapan dari sesi tersebut bersifat anonim, fasilitator yang terampil dapat memimpin kelompok yang dipilih melalui diskusi. Data yang dihasilkan dapat membentuk dasar untuk meluncurkan program etika di seluruh perusahaan atau meningkatkan program yang ada. 


\section{F. Kode Etik Perilaku Bisnis}

Pernyataan misi adalah kunci untuk menyatukan keseluruhan struktur tata kelola perusahaan, kode perilaku seluruh perusahaan memberikan panduan pendukung untuk semua pemangku kepentingan terkait. Perusahaan yang efektif saat ini harus mengembangkan dan menegakkan kode etik yang mencakup aturan etika, bisnis, dan hukum yang berlaku untuk semua pemangku kepentingan perusahaan.

Untuk melengkapi infrastruktur etik dan mendeteksi adanya pelanggaran kode etik dan pedoman perilaku, perusahaan harus menerapkan sistem pelaporan pelanggaran melalui Whistle Blowing System.

\section{Isi Kode Etik: Apa yang Harus Menjadi Pesan Kode?}

Kode etik haruslah merupakan seperangkat aturan atau panduan yang jelas dan tidak ambigu yang menguraikan apa yang diharapkan dari semua pemangku kepentingan perusahaan, baik penyedia jasa, karyawan, kontraktor, vendor, atau lainnya. Kode tersebut harus didasarkan pada nilai-nilai dan masalah hukum yang melingkupi perusahaan. Kode etik harus berlaku untuk semua anggota perusahaan dari tingkat paling senior hingga karyawan paruh waktu.

Jika perusahaan sudah memiliki kode etik, auditor internal bisa menjadwalkan peninjauan dari waktu ke waktu untuk meninjau kembali kode itu. Berdasarkan SOx dan pedoman tata kelola perusahaan kode etik sebaiknya berlaku untuk semua pemangku kepentingan perusahaan.

Tim gabungan dari lintas manajemen, harus dibentuk untuk mengembangkan kode etik. Tim harus memeriksa masalah bisnis yang dihadapi perusahaan dan kemudian 
menyusun seperangkat aturan yang berlaku untuk perusahaan itu. Kode etik harus ditulis dengan cara yang jelas sehingga poin dapat dengan mudah dipahami oleh semua.

Kode etik dari satu perusahaan ke perusahaan yang lain bisa berbeda dalam gaya, format, dan ukuran. Perusahaan skala global memiliki masalah lain ketika mengembangkan kode etik karena memiliki operasi yang signifikan di seluruh dunia di mana manajer kunci, karyawan, dan pemangku kepentingan lainnya tidak menggunakan bahasa Inggris sebagai bahasa utama mereka. Perusahaan harus mempertimbangkan untuk memproduksi kode versi bahasa utama dinegara dimana anak perusahaan beroperasi.

\section{Komunikasi dengan Pemangku Kepentingan dan Memastikan} Kepatuhan

Kode etik suatu perusahaan harus merupakan dokumen hidup. Jika dokumen tersebut merupakan kode perilaku baru atau revisi besar, perusahaan harus melakukan upaya yang sungguh-sungguh untuk mensosialisasikan semua karyawan dan pemangku kepentingan.

Skandal keuangan biasanya dipicu oleh kode perilaku yang hanya berlaku untuk staf. Contoh; Enron dan WorldCom memiliki kode etik perusahaan yang memadai, tetapi manajemen senior bahkan direktur utama tidak merasa bahwa kode perilaku berlaku untuk mereka.

Oleh sebab itu setiap manajemen senior harus secara formal mengakui bahwa mereka telah membaca, memahami, dan akan mematuhi kode perilaku. Dengan tim manajemen berdiri di belakangnya, perusahaan selanjutnya 
harus meluncurkan dan kemudian mensosialisasikan kode etik kepada semua pemangku kepentingan perusahaan. Setiap pemangku kepentingan perusahaan diminta untuk menjawab tiga pertanyaan berikut:

a. Sudahkah Anda menerima dan membaca salinan kode etik? Jawab ya atau tidak.

b. Apakah Anda memahami isi kode etik? Jawab ya jika Anda memahami kode etik ini atau tidak jika Anda memiliki pertanyaan.

c. Apakah Anda setuju untuk mematuhi kebijakan dan pedoman dalam kode etik ini? Jawab ya jika Anda setuju untuk mematuhi kode dan tidak jika Anda tidak.

Respons harus dicatat pada database yang mencantumkan nama karyawan dan tanggal peninjauan serta penerimaan atau penerimaannya. Idenya adalah meminta semua orang merespon positif kode etik dan menyetujui persyaratannya. Jika seseorang menolak untuk menerima kode perilaku orang tersebut harus mendiskusikan dengan manajer senior untuk mendapatkan penyelesaian. Perusahaan harus memastikan semua karyawan setuju untuk menerima dan mematuhi kode etiknya. Kegagalan secara konsisten untuk mematuhi aturannya harus menjadi dasar untuk pemutusan hubungan kerja.

\section{Pelanggaran Kode dan Tindakan Korektif}

Selain menerbitkan kode etik dan mendapatkan penerimaan pemangku kepentingan, ada juga kebutuhan mekanisme untuk melaporkan pelanggaran kode dan untuk menyelidiki dan menangani pelanggaran-pelanggaran tersebut. Jika perusahaan mengeluarkan kode perilaku yang 
kuat semua pemangku kepentingan diharapkan untuk mengikuti aturan itu. Namun, kita semua tahu bahwa orang adalah orang dan akan selalu ada beberapa yang melanggar aturan atau berjalan di ujung tanduk. Suatu perusahaan perlu membuat mekanisme untuk memungkinkan karyawan atau bahkan orang luar melaporkan potensi pelanggaran kode dengan cara yang aman dan rahasia.

Selain fasilitas whistleblower, perusahaan harus menetapkan mekanisme lain untuk melaporkan potensi pelanggaran kode etik, bisa dilakukan dengan fasilitas hotline etika atau kotak saran terkadang sangat efektif. Berdasarkan tanggapan ini, fungsi etika, sumber daya manusia, atau fungsi lain dalam perusahaan harus menyelidiki masalah ini dan mengambil tindakan seperlunya.

Ketika pelanggaran ditemukan, masalah tersebut harus diselidiki dan tindakan diambil atas dasar yang konsisten, tidak peduli pangkat pemangku kepentingan perusahaan. Kalau tidak, bisa jadi ada atmosfir di mana aturan tampak hanya berlaku untuk beberapa orang. Sebagian besar pelanggaran kode etik dapat ditangani melalui prosedur sumber daya manusia perusahaan. pelanggaran pertama dapat mengakibatkan konseling atau hukuman percobaan, dengan penghentian karena pelanggaran berulang.

Beberapa hal harus dilaporkan kepada pihak luar. Pelanggaran aturan SOx, seperti pengaturan off-balancesheet yang tidak berdokumen, akan dilaporkan ke Komisi Sekuritas dan Bursa (SEC); pencurian barang dari gudang akan dilaporkan ke jaksa wilayah. Ketika masalah ini ditemukan dan dilaporkan ke pihak berwenang, masalah 
tersebut bergerak di luar tangan perusahaan. Tujuannya di sini adalah agar perusahaan memiliki beberapa proses untuk mendorong semua pemangku kepentingan untuk mengikuti praktik etika yang baik.

\section{Menjaga Kode Etik Agar Tetap Terkini}

Banyak aturan dasar perilaku etis yang tidak akan berubah dari tahun ke tahun. Misalnya, aturan tentang perlindungan aset perusahaan, yang dikutip sebelumnya, menyatakan bahwa semua pemangku kepentingan memiliki tanggung jawab untuk merawat aset perusahaan mereka, baik properti, uang tunai, sumber daya $\mathrm{TI}$, atau lainnya. Jenis aturan etis semacam itu tidak akan berubah seiring waktu, tetapi yang lain mungkin berubah karena bisnis atau kondisi lainnya. Perusahaan harus meninjau kode etik yang diterbitkan secara berkala dan setidaknya sekali setiap dua tahun untuk memastikan pedoman ini masih berlaku dan terkini. Ini mungkin termasuk pernyataan kode tentang perlunya whistlebloweran keuangan yang akurat dan tepat waktu di semua tingkatan atau komitmen perusahaan untuk menghindari segala jenis penipuan keuangan. Perubahan pada kode etik tidak boleh dianggap enteng. Setiap revisi harus melalui proses pengumuman dan peluncuran yang sama seperti yang dijelaskan sebelumnya untuk pengenalan kode. Kode yang revisi harus dsosialisasikan kepada semua pemangku kepentingan dan penjelasan tentang perubahan serta persyaratan untuk mengakui kembali penerimaan.

Ketika karyawan baru dan pemangku kepentingan lainnya baru bergabung dengan perusahaan, mereka harus diberi kode etik dengan persyaratan yang sama. Bagian SDM 
diberikan tugas untuk menjelaskan dan mendidik karyawan baru mengenai kode etik dan komitmen perusahaan terhadapnya.

Revisi kode etik baru dan permintaan untuk penegasan kembali pemangku kepentingan merupakan dari fungsi etika, sumber daya manusia, audit internal, dan lainnya untuk mensosialisasikan bersamaan dengan pernyataan misi. Audit internal harus memainkan peran kunci dalam mempromosikan kode dan memantau kepatuhan melalui tinjauan audit. Auditor internal harus sangat menyadari kode etik perusahaan mereka dan menggunakannya sebagai dasar untuk melaporkan pelanggaran dan membuat rekomendasi dalam proses semua audit internal lainnya.

\section{G. Fungsi Whistleblower dan Hotline}

SOx mengamanatkan bahwa komite audit perusahaan menetapkan prosedur untuk "menangani informasi whistleblower terkait masalah akuntansi atau audit yang dipertanyakan." Fungsi pengungkap fakta adalah fasilitas di mana karyawan atau pemangku kepentingan mana pun yang melihat beberapa bentuk kesalahan dapat melaporkannya secara independen dan tanpa nama ke perusahaan atau kepada otoritas pengatur tanpa takut akan pembalasan.

Banyak perusahaan yang memiliki fungsi etika juga memiliki saluran telepon hotline. Hotline etika ini dapat memberikan titik awal untuk fungsi whistleblower. Terlalu sering, insiden yang dilaporkan tidak diselidiki dengan cara yang tepat atau kerahasiaannya tidak cukup kuat. Kesalahan ini dapat menyebabkan masalah besar bagi perusahaan jika whistleblowing 
merasa bahwa masalah belum diselesaikan atau kerahasiaan individu telah dikompromikan.

Seorang karyawan bisa menjadi whistleblower, misalnya, yang mengamati bahwa bahan makanan yang diproduksi tampaknya kurang inspeksi keselamatan yang tepat dapat memberi tahu atasannya tentang kemungkinan pelanggaran ini.

Program whistleblower yang dimandatkan SOx memberikan tantangan baru lainnya kepada anggota komite audit yang bertanggung jawab. Tim auditor internal sering dapat membantu komite audit untuk membentuk program pengungkap fakta yang efektif untuk mematuhi SOx.

\section{Aturan Whistleblower Federal}

SOx telah memperluas perlindungan whistleblower federal ini. Dalam banyak hal, ketentuan pengungkap fakta dirancang terutama untuk melindungi karyawan yang merasa telah menemukan kesalahan. Secara virtual, setiap tindakan yang diambil terhadap karyawan whistleblower berpotensi dapat dikenakan tindakan hukum berdasarkan ketentuan ini. SOx mensyaratkan komite audit untuk menetapkan proses penerimaan dan penanganan pengaduan yang diterima terkait akuntansi, pengendalian internal, atau masalah audit, dan untuk "merahasiakan nama karyawan". Whistleblower yang dirugikan dapat meminta ganti rugi melalui tindakan pengadilan yang terpisah.

\section{Aturan Whistleblower SOx dan Audit Internal}

Di bawah SOx, karyawan atau pemangku kepentingan mana pun dapat menjadi whistleblower dengan melaporkan kegiatan akuntansi, pengendalian internal, dan audit yang ilegal atau tidak patut. Ini harus menjadi proses yang efektif 
ketika whistleblower potensial adalah anggota staf akuntansi perusahaan. Aturan whistleblower dirancang untuk mendorong pemangku kepentingan untuk melaporkan tindakan penipuan atau ilegal ini dan melindungi orang yang melaporkan masalah tersebut. Tim audit internal jelas merupakan bagian dari manajemen, dan auditor internal memiliki tanggung jawab untuk melaporkan segala hal yang tidak patut atau ilegal yang terjadi selama audit ke manajemen. Audit internal harus mengembangkan kebijakan yang jelas yang menyatakan bahwa masalah akuntansi, pengendalian internal, atau audit yang terjadi selama tinjauan audit harus didokumentasikan dalam kertas kerja audit dan dikomunikasikan kepada manajemen audit internal untuk penyelesaian. Baik tim audit internal dan manajemen fungsi yang diaudit harus memahami bahwa tujuan audit internal adalah tidak untuk menjadi tim whistleblower. Namun barang-barang ilegal atau tidak patut harus diselidiki dan dilaporkan melalui audit internal dengan proses normal.

\section{Meluncurkan Fungsi Hotline}

Banyak perusahaan memiliki fungsi bantuan atau hotline, yang dikelola melalui departemen etika, sumber daya manusia, atau penyedia independen, yang memungkinkan karyawan atau pemangku kepentingan untuk menelepon secara anonim dan mengajukan pertanyaan, melaporkan masalah, mengenai suatu hal. Idenya adalah untuk menyediakan fasilitas independen di mana semua pemangku kepentingan dapat mengajukan pertanyaan atau melaporkan kemungkinan kesalahan di tingkat mana pun. 
Sekarang banyak hotline etika yang sudah mapan dibuat untuk menjadi "ramah" dalam menjawab pertanyaan karyawan dan memberikan beberapa saran selain untuk menyelidiki insiden yang dilaporkan, menggunakan jenis fasilitas ini untuk program whistleblower SOx menempatkan pengendalian dan tanggung jawab baru pada suatu perusahaan. Sebuah hotline etika dan fasilitas whistleblower akan bernilai kecil, kecuali jika telah dikomunikasikan kepada semua anggota perusahaan.

\section{H. Mengaudit Fungsi Etika Perusahaan}

Fungsi etika dan hotline tidak boleh dikecualikan dari jenis tinjauan operasional atau keuangan yang dilakukan oleh audit internal di semua segmen lain dari perusahaan. Berbeda dari manajemen aset, pemasaran, atau rekayasa desain, yang secara berkala tunduk pada tinjauan operasional dan keuangan berdasarkan risiko audit potensial, fungsi etika harus tetap dimasukkan dalam jenis model analisis risiko yang sama yang digunakan oleh audit internal untuk perencanaan audit. Meskipun fungsi kode etik dapat menimbulkan risiko minimal, fungsi whistleblower terutama jika dikelola secara internal dapat menghadirkan risiko keamanan dan kerahasiaan besar.

Tujuan dari tinjauan audit internal terhadap fungsi etika dan whistleblower adalah untuk menilai apakah fungsi etika tersebut mengikuti prosedur pengendalian internal yang baik, memanfaatkan sumber dayanya secara efektif, mematuhi prosedur kerahasiaan yang baik, dan mengikuti piagam departemennya yang mengesahkan fungsi etika. Sementara setiap fungsi etika dan whistleblower mungkin sedikit berbeda, audit internal harus mendapatkan pemahaman terperinci tentang 
bagaimana fungsi beroperasi dan prosedur biasanya dilakukan. Sebagai fungsi etika perusahaan, audit internal harus menemukan dokumen prosedur mengenai, seperti kepatuhan pada kerahasiaan dan kepatuhan atas kebijakan perusahaan seperti biaya perjalanan. Fungsi etika lainnya tanggung jawab dapat menunjuk ke area di mana audit internal dapat menyarankan perbaikan. Misalnya, fungsi etika biasanya harus memiliki formulir atau proses pengakuan di mana karyawan telah membaca dan memahami kode tersebut. Fungsi etika mungkin belum menetapkan prosedur yang tepat untuk memastikan bahwa semua karyawan yang baru direkrut telah membaca dan pengakuan kode ini.

Karena hubungan yang erat dan berkelanjutan yang seharusnya ada antara fungsi etika dan audit internal, jika tinjauan operasional etika muncul sebagai bagian dari analisis risiko audit, auditor kepala harus membahas tinjauan yang direncanakan dengan direktur etika dengan untuk menjelaskan alasan dan tujuan dari tinjauan operasional yang direncanakan. Privasi dan kerahasiaan dapat menjadi masalah dalam jenis ulasan ini. Panggilan ke hotline mungkin menunjuk ke beberapa karyawan bentuk penyimpangan potensial, dan fungsi etika ingin menjaga kerahasiaan hingga masalah diselesaikan. Meskipun audit internal sedang berlangsung untuk area sensitif direktur fungsi etika mungkin enggan untuk meminta auditor internal meninjau materi yang sensitif tersebut. Namun Kepala eksekutif audit harus memberi tahu pada fungsi etika bahwa auditor internal memegang teguh kerahasiaan hasil temuan sehingga informasi sensitif harus tetap menjadi tinjauan audit internal. 
Dengan asumsi bahwa masalah ini dapat diselesaikan dengan tepat, tinjauan operasional atas fungsi etika akan memberikan jaminan tambahan kepada manajemen tentang integritas pengendalian dalam fungsi etika, komponen operasi di mana sebagian besar manajer memiliki sedikit paparan atau pengalaman.

\section{Meningkatkan Program Tata Kelola Perusahaan}

Program etika yang kuat, berdasarkan pada pernyataan misi yang bermakna dan kode perilaku, adalah elemen kunci untuk semua program tata kelola perusahaan secara keseluruhan. Skandal akuntansi yang mengarah ke SOx dalam banyak hal adalah skandal di tingkat atas perusahaan, apakah disebabkan oleh petugas keuangan licik, CEO serakah, atau akuntan publik perusahaan. Hal itu karena tim eksekutif perusahaan menetapkan aturan mereka sendiri tanpa melibatkan dewan direks. Hasilnya adalah Sox, sangat fokus pada kelompok senior. Idealnya adalah program etika yang kuat akan meningkatkan praktik tata kelola untuk seluruh perusahaan.

Auditor internal harus sangat menyadari kebutuhan akan tata kelola perusahaan dan kebijakan etika perusahaan secara keseluruhan. Auditor internal harus memiliki program etika dan kepatuhan yang kuat di dalam tim audit internal. Kebijakan manajemen senior perusahaan harus menekankan bahwa semua pemangku kepentingan didorong memiliki kewajiban untuk melaporkan tentang praktik curang akuntansi dan keuangan. Pernyataan kebijakan harus menekankan bahwa manajemen tidak akan mentoleransi pembalasan terhadap karyawan yang menyampaikan pelaporan penyimpangan keuangan. Kebijakan 
melindungi pelapor kecurangan dapat membantu mendorong mengatasi masalah.

\section{J. Simpulan}

Audit internal memiliki peran utama dalam menyurvei sikap dan praktik karyawan terkait etika. Sikap dan risiko etika dapat dinilai melalui tinjauan atas temuan dari audit sebelumnya atau melalui tinjauan khusus berdasarkan survei sikap karyawan dan pemangku kepentingan. Survei etika adalah cara yang sangat baik untuk memahami sikap perusahaan dan merupakan bantuan untuk mendukung proses tata kelola perusahaan.

Mekanisme whistleblower harus dijalankan secara konsisten dan dijaga sehingga betul efektif berjalan. Sistem whistleblower dibuat sebagai bentuk upaya perlawanan terhadap praktik korupsi. Dengan adanya sistem whistleblower, semua pegawai sampai komisaris bisa melaporkan adanya indikasi korupsi di internal perusahaan. Bahkan, masyarakat juga bisa melakukan hal yang sama.

\section{K. Contoh Kasus Mengaudit Fungsi Etika Perusahaan}

Korupsi adalah fenomena global. Tidak ada organisasi yang kebal dari korupsi atau pelanggaran lainnya, termasuk lembaga pendidikan tinggi (universitas). Meskipun belum ada data statistik tentang kasus korupsi yang melibatkan universitas di Indonesia, ada beberapa kasus yang menjadi berita utama selama 20182019. Beberapa di antaranya adalah kasus korupsi menyangkut pembangunan rumah sakit Universitas Udayana, pembangunan laboratorium Universitas Negeri Malang, dan pembangunan Fakultas Politik Universtas Riau.

Skema korupsi umum yang terjadi di universitas-universitas ini dilakukan dengan me-markup anggaran untuk pembangunan fasilitas universitas dan kecurangan saat tender. Selain itu, KPK mengatakan awal tahun ini bahwa mereka menerima banyak 
laporan dugaan kasus korupsi di kampus, salah satu modusnya yaitu penyuapan untuk penerimaan mahasiswa baru.

Korupsi dalam dunia akademi, khususnya universitas, menyebabkan kerugian moral dan reputasi. Hal terburuk tentang korupsi di dunia akademis adalah para korbannya adalah para mahasiswa. Memberikan toleransi terhadap tindakan korupsi sama dengan menunjukkan kepada mahasiswa bahwa korupsi adalah hal yang lumrah.

Menurut Transparansi Internasional, dalam jangka panjang, tindakan korupsi di institusi pendidikan akan memiliki implikasi yang merugikan bagi kualitas pendidikan dan hasil belajar siswa. Pada akhirnya, korupsi merusak kredibilitas dan reputasi universitas.

\section{Solusi}

Oleh karena itu, sangat penting bagi universitas untuk konsisten mengembangkan dan memberlakukan standar etika dan kode etik dengan tujuan mencegah terjadinya suap, korupsi, fraud dan pelanggaran lainnya. Upaya ini bisa dilakukan salah satu cara dengan cara menerapkan sistem whistleblowing (WBS).

Fungsi sistem whistleblowing memungkinkan universitas mendeteksi penyuapan, penyalahgunaan, atau kecurangan lainnya sedini mungkin. Dengan begitu potensi kerugian dapat dikurangi secara signifikan. Meskipun diketahui bahwa universitas yang terlibat dalam kasus-kasus korupsi tersebut tidak memiliki WBS, beberapa universitas di Indonesia diketahui telah menerapkan WBS, seperti UI (SIPDUGA UI), UGM (SIAP UGM), dan Universitas Bina Nusantara.

\section{Pertanyaan untuk didiskusikan}

1. Apa yang harus menjadi pesan kode etik?

2. Bagaimana cara mengaudit fungsi etika?

3. Bagaimana cara menjaga kode etik supaya dapat sesuai dengan perubahan yang terjadi? 
4. Apa yang anda pahami terkait dengan whistleblower?

Soal Kasus

Daud Ndakularak adalah pelapor yang beritikad baik dalam perkara tindak pidana pengelolaan dana kas APBD Kabupaten Sumba Timur TA 2005-2006 yang proses penyidikannya telah ditangani oleh kepolisian Resor Sumba Timur dan telah di putus oleh Pengadilan Tipikor Kupang,

Dalam posisinya sebagai terlindung LPSK Daud telah melakukan berbagai upaya yang yang sesuai dengan perintah undang-undang khususnya dalam penegakan kasus korupsi. la telah melindungi banyak alat bukti dan melaporkan kasus tersebut ke Polres Sumba Timur.

Namun naas, karena statusnya sebagai pelapor Korupsi, saudara Daud Ndakularak mendapatkan serangan pembalasan. Tindak Pidana Korupsi yang dilaporkannya justru membuat ia dijadikan tersangka.

Agar kasus serupa tidak terjadi apa yang harus dilakukan oleh whistleblower

\section{Daftar Pustaka}

Moeller, R. R. (2016). Brink's Modern Internal Auditing Eighth Edition A Common Body of Knowledge Published by John Wiley \& Sons, Inc., Hoboken, New Jersey.

Sarbanes. (2002). Sarbanes-Oxley Act of 2002. Corporate responsibility. 


\section{BAB 14}

\section{INTERNAL AUDIT DAN PENCEGAHAN FRAUD}

\section{Capaian pembelajaran}

1. Mahasiswa mampu memahami konsep kecurangan.

2. Mahasiswa mampu memahami untuk mendetaksi kecurangan.

3. Mahasiswa mampu memahami standar IIA untuk mendeteksi dan investigasi kecurangan.

4. Mahasiswa mampu memahami proses pencegahan penipuan teknologi informasi.

\section{A. Pendahuluan}

Dalam konteks audit kecurangan, sangat penting untuk menetapkan sejauh mana kecurangan menyebabkan konsekuensi terkait keuangan yang dapat diukur secara langsung, atau tidak langsung bagi perusahaan. Kecurangan yang dapat diukur dengan keuangan harus dikomunikasikan kepada badan-badan terkait secara langsung karena dampak potensial pada pelaporan keuangan. Namun, kecurangan yang tidak memiliki dampak keuangan tidak boleh diabaikan karena dapat menyebabkan kerusakan pada reputasi perusahaan, kerusakan lingkungan, pengunduran diri staf, cacat produk dan layanan, dan hilangnya kepercayaan.

Setiap tahun, milyaran dolar hilang karena kecurangan dan korupsi yang mengakibatkan inefisiensi, kegagalan proyek, kendala finansial, kegagalan organisasi, dan dalam kasus-kasus ekstrim, bencana kemanusiaan. Seringkali kecurangan terjadi karena pengendalian internal tidak dirancang dengan baik dan lemahnya 
tata kelola. Organisasi sudah seharusnya memiliki prosedur pengendalian internal yang kuat untuk membatasi risiko kecurangan.

Kecurangan tidaklah unik bagi tipe organisasi tertentu. Kecurangan dapat terjadi di bisnis publik dan swasta, nirlaba, maupun di organisasi yang berupaya berkontribusi pada kesejahteraan ekonomi dan sosial. Singkatnya, peluang untuk melakukan kecurangan ada di mana-mana. Bagaimana organisasi menghadapi risiko kecurangan dipengaruhi oleh yurisdiksi hukum dan penilaian risiko serta selera risiko.

Sejalan dengan Standar Internasional IIA untuk Praktek Profesional Audit Internal tentang kecakapan, auditor internal yaitu harus memiliki pengetahuan yang memadai untuk mengevaluasi risiko kecurangan dan cara organisasi mengelola risiko tersebut. Peran audit internal untuk mendeteksi, mencegah, dan memantau risiko kecurangan dan mengatasi risiko tersebut melalui audit dan investigasi.

Internal audit harus merespon secra tepat ketika ada risiko kecurangan dalam bisnis dengan melakukan audit atas pengendalian serta mengevaluasi potensi timbulnya kecurangan dan bagaimana organisasi mengelola risiko kecurangan tersebut melalui penilaian risiko. Kecurangan merupakan tanggung jawab manajemen sebagai garis pertahanan pertama (first line of defense).

Audit internal harus menggunakan keahliannya untuk menganalisa kumpulan data untuk mengidentifikasi tren dan pola yang mungkin mengarah pada kecurangan dan penyalahgunaan dana. Jika tim audit internal tidak memiliki keahlian tersebut, organisasi harus mempertimbangkan untuk merekrut atau melibatkan sumber daya dengan pengetahuan atau keahlian yang 
memadai. Organisasi harus memiliki rencana respons antikecurangan yang memadai dengan membuat kebijakan utama dan metodologi investigasi.

Secara operasional, audit internal semestinya memiliki pengetahuan kecurangan yang cukup untuk:

a. Mengidentifikasi petunjuk (red flag) yang mengindikasikan kecurangan mungkin telah terjadi.

b. Memahami karakteristik kecurangan dan teknik yang digunakan untuk melakukan kecurangan, dan berbagai skema serta skenario kecurangan.

c. Mengevaluasi indikator kecurangan dan memutuskan apakah tindakan lebih lanjut diperlukan atau apakah investigasi perlu direkomendasikan.

d. Mengevaluasi efektivitas pengendalian untuk mencegah atau mendeteksi kecurangan.

Jika terjadi kecurangan, audit internal semestinya memahami bagaimana pengendalian telah gagal dan mengidentifikasi peluang untuk perbaikan. Audit internal juga seharusnya mempertimbangkan kemungkinan kesalahan, kecurangan, atau ketidakpatuhan terjadi kembali di seluruh organisasi.

Ernst \& Young melakukan survei tahunannya melaporkan bahwa $85 \%$ dari kecurangan terburuk disebabkan oleh orang dalam dan lebih dari setengah dari kecurangan diprakarsai oleh anggota manajemen senior. Kecurangan perusahaan adalah masalah yang akan selalu ada, tetapi auditor internal dapat membantu mencegah dan mendeteksi kecurangan melalui ulasan pengendalian internal yang efektif. 
Audit internal yang efektif perlu mengenali potensi praktik kecurangan bisnis sebagai bagian dari audit apa pun dan kemudian harus merekomendasikan pengendalian dan prosedur untuk membatasi paparan terhadap aktivitas kecurangan. Terdapat beberapa tanda kondisi umum yang mungkin dihadapi oleh audit internal ketika menghadapi potensi kecurangan dan kemudian membahas langkah-langkah untuk mengidentifikasi, menguji, dan memproses dengan baik kegiatan kecurangan. Penyelidikan kecurangan dapat menjadi kegiatan yang sangat terperinci dan terspesialisasi, tetapi semua auditor internal harus memiliki pemahaman tentang cara mengendus kecurangan dan cara mengaudit kegiatan yang berpotensi kecurangan serta proses untuk menyelidiki dan melaporkan kecurangan. Kegiatan kecurangan mewakili gangguan dalam berbagai praktik dan prosedur yang baik, tetapi auditor internal harus menyadari bahwa kegiatan kecurangan mungkin selalu ada.

\section{B. Memahami Kecurangan}

Langkah pertama auditor internal yang penting di sini adalah memahami definisi hukum tentang apa yang disebut kecurangan. Definisi common-law kecurangan adalah memperoleh uang atau properti dengan menggunakan perangkat palsu. Dengan kata lain, seseorang secara tidak sah mengotorisasi beberapa dokumen yang menyebabkan transfer uang. Kecurangan berdampak sangat mahal untuk perusahaan apa pun yang menjadi korban, dan pengendalian internal yang efektif adalah garis pertahanan pertama perusahaan terhadap kecurangan. Sistem pengendalian internal yang komprehensif harus dilaksanakan dan dipantau secara teratur untuk pencegahan dan deteksi kerugian yang timbul dari kecurangan. 
Namun, secara historis, baik auditor internal maupun eksternal tidak secara teratur mencari kecurangan sebagai bagian dari audit terjadwal. Sekarang audit kecurangan menjadi hal yang penting bagi perusahaan.

Auditor saat ini, baik internal maupun eksternal mengambil peran yang lebih penting dalam deteksi dan pencegahan kecurangan. Materi panduan bersama tentang dampak kecurangan dalam audit juga telah dirujuk dari materi panduan AICPA, IIA, dan ACFE.

\section{Red Flags: Sinyal untuk Mendetaksi Kecurangan}

Seorang karyawan dari sebuah perusahaan yang telah menggelapkan uang dalam waktu yang lama sering kali pada akhirnya akan ditangkap melalui slip-up oleh audit kecurangan, atau jenis audit apapun. Mudah untuk menganalisis tindakan setelah kecurangan ditemukan, tetapi auditor internal dan manajemen harus mencari indikator (red flags) kemungkinan kegiatan kecurangan yang dilakukan semua stakeholders.

Gambar 14.1 mencantumkan beberapa red flags yang berpotensi menunjukkan kemungkinan kegiatan kecurangan finansial. Namun red flags bukan merupakan indikator kecurangan mutlak, tetapi auditor internal harus selalu skeptis dalam ulasan mereka dan menyadari sinyal peringatan tersebut. Ketika seorang auditor internal melihat bukti dari satu atau lebih red flags mungkin sudah waktunya untuk menggali sedikit lebih dalam untuk mengidentifkasi kecurangan. Sayangnya, auditor internal sering gagal mendeteksi kecurangan karena salah satu alasan berikut:

a. Ada keengganan untuk mencari kecurangan. Karena pelatihan dan pengalaman masa lalu mereka, auditor internal secara historis tidak aktif mencari kecurangan. 
b. Terlalu banyak kepercayaan ditempatkan di pihak yang diaudit. Auditor internal, khususnya, mencoba mempertahankan sikap ramah terhadap pihak yang diaudit di perusahaan mereka.

c. Tidak cukup penekanan ditempatkan pada masalah kecurangan potensial dalam temuan audit. laporan audit temuan hanya menunjukkan hal-hal seperti catatan yang hilang atau akun yang tidak direkonsiliasi. Namun, auditor internal sering gagal mempertimbangkan potensi kecurangan dalam temuan audit. Walaupun itu adalah masalah yang sangat besar, auditor internal bahkan tidak berpikir tentang masalah kecurangan ketika mengembangkan temuan audit.

d. Masalah kecurangan seringkali menerima dukungan yang tidak memadai dari manajemen. Petunjuk kemungkinan kecurangan mengharuskan auditor untuk memperpanjang prosedur audit dan menggali lebih dalam. Namun, manajemen audit secara umum dan bahkan mungkin enggan memberikan waktu tambahan kepada seorang auditor untuk melakukannya.

e. Auditor terkadang gagal untuk fokus pada area kecurangan berisiko tinggi. Kecurangan dapat terjadi di banyak bidang, mulai dari pelaporan biaya perjalanan karyawan hingga hubungan fungsi keuangan dengan bank. Audit internal sering tidak mencakup area berisiko tinggi seperti, misalnya, peninjauan hubungan fungsi treasuri dengan bank, area yang sering kompleks dan sulit ditinjau.

Kecurangan adalah kata yang dapat memiliki banyak makna, tetapi kami menyebutnya sebagai tindak pidana. Ada lebih dari 300 referensi tentang kecurangan dalam undang-undang pidana federal, dan istilah ini muncul di seluruh undang-undang SOx. Sebagian besar 
referensi federal didasarkan pada undang-undang kecurangan umum federal:

Daftar berikut mewakili "red flags" yang mungkin merupakan sinyal peringatan untuk bukti kecurangan keuangan. Ini diadaptasi dari situs web AICPA, www.aicpa.org.

a. Kurangnya kebijakan tertulis perusahaan dan prosedur operasi standar.

b. Berdasarkan wawancara di berbagai tingkatan, kurangnya kepatuhan dengan kebijakan pengendalian internal organisasi.

c. Lemahnya kebijakan pengendalian internal, terutama dalam pembagian tugas.

d. Operasi yang tidak terorganisir di bidang-bidang seperti pembelian, penerimaan, pergudangan, atau kantor regional.

e. Transaksi yang tidak tercatat atau catatan yang hilang.

f. Dokumen palsu atau bukti perubahan dokumen.

g. Fotokopi tulisan tangan yang dipertanyakan.

h. Catatan penjualan kredit yang berlebihan.

i. Rekening bank tidak direkonsiliasi tepat waktu.

j. Kondisi tidak seimbang yang berkelanjutan pada buku besar pembantu.

k. Hubungan laporan keuangan yang tidak biasa.

I. Perbedaan terus menerus yang tidak dapat dijelaskan antara jumlah persediaan fisik dan catatan persediaan.

$\mathrm{m}$. Cek bank ditulis dalam bentuk tunai dalam jumlah besar.

n. Pemeriksaan tulisan tangan di lingkungan komputer

o. Transfer dana terus menerus atau tidak biasa di antara rekening bank perusahaan.

p. Transfer dana ke bank luar negeri.

q. Transaksi tidak konsisten dengan bisnis entitas. 
r. Prosedur penyaringan yang buruk untuk karyawan baru termasuk tidak ada pemeriksaan latar belakang atau referensi.

s. Keengganan oleh manajemen untuk melaporkan kesalahan pidana.

t. Pemindahan aset pribadi yang tidak biasa.

u. Petugas atau karyawan dengan gaya hidup tampaknya di luar kemampuan mereka.

v. Waktu liburan yang tidak digunakan.

w. Transaksi pihak terkait yang sering atau tidak biasa.

x. Pimpinan atau karyawan memiliki hubungan dekat dengan pemasok.

y. Karyawan yang memiliki hubungan dekat satu sama lain di bidang di mana pemisahan tugas dapat dihindari.

z. Penyalahgunaan biaya akun seperti manajer yang tidak mengikuti aturan yang ditetapkan.

aa. Aset bisnis menghilang tanpa penjelasan.

Gambar 14.1 Red Flags yang Menunjukkan Potensi Penipuan Keuangan

Sumber : (Moeller.R.R. 2016)

Untuk membantu mendeteksi kecurangan, auditor harus memiliki pemahaman tentang mengapa orang melakukan kecurangan. Ada beberapa motivasi, alasan, atau alasan tipikal untuk melakukan kecurangan. Deteksi kecurangan jauh lebih sulit ketika ada kolusi antara banyak orang. Setiap kali banyak orang terlibat dalam kecurangan yang sama, ada kemungkinan seseorang akan mematahkannya. Sementara kecurangan besar yang melibatkan partisipasi manajemen senior sulit untuk dihilangkan, kecurangan yang terjadi pada tingkat yang lebih rendah di perusahaan seringkali 
lebih mudah dideteksi dengan tingkat penyelidikan auditor internal yang tepat.

\section{Standar IIA Untuk Mendeteksi dan Investigasi Kecurangan}

Auditor internal sering dalam posisi yang lebih baik untuk mendeteksi kecurangan dalam operasi perusahaan daripada auditor eksternal. Hanya melalui pengamatan mereka sendiri, auditor internal mungkin berada dalam posisi yang jauh lebih baik untuk melihat red flags.

Misalnya petugas pengawas pengiriman barang yang muncul di pesta liburan tahunan mengenakan setelan Italia yang mahal dan memakai arloji emas bermerek bisa menimbulkan beberapa dugaan dari peserta pihak lain maupun seorang auditor internal. Ada banyak alasan yang sangat sahih untuk membenarkan pakaian mahal, tetapi pertunjukan kekayaan semacam itu bisa menjadi sesuatu yang perlu diingat oleh auditor internal ketika melangkah maju dengan tinjauan pengendalian internal yang dijadwalkan di area itu.

Auditor internal mengalami banyak masalah kesadaran seperti itu dan potensi masalah kecurangan dalam tinjauan terjadwal mereka. Mereka juga biasanya terlibat dalam ulasan tingkat transaksi yang jauh lebih terperinci daripada rekan audit eksternal dan lebih sering melihat dokumen atau transaksi yang dipertanyakan. Jika manajemen merasa ada kecurangan potensial di beberapa unit perusahaan, langkah pertama adalah hampir selalu menghubungi audit internal. Mereka dapat mendiskusikan masalah potensial apa pun di sana dan mendapatkan masukan cepat tentang apakah suatu kekhawatiran memerlukan lebih banyak perhatian. Jika ada tandatanda kuat adanya kecurangan aktif, bagian hukum perusahaan hampir selalu siap untuk terjun ke masalah ini dan membantu. 
Standar internasional IIA menekankan bahwa meskipun audit internal memiliki peran untuk tanggung jawab utama deteksi dan pencegahan kecurangan. Standar profesional IIA yang mencakup perawatan profesional yang wajar dan ruang lingkup pekerjaan mencakup kecurangan dalam arti yang sangat umum. Auditor internal akan khawatir tentang hal-hal seperti kemungkinan kesalahan dan harus mempertimbangkan bukti dari kegiatan yang tidak pantas atau ilegal dalam audit.. Menyadari bahwa mungkin sulit untuk mendeteksi kecurangan, standar IIA 1210.A2 memberikan panduan: "Auditor internal harus memiliki pengetahuan yang memadai untuk mengidentifikasi indikator-indikator kecurangan tetapi tidak diharapkan memiliki keahlian khusus seperti seseorang yang tanggung jawab utamanya mendeteksi dan menyelidiki kecurangan.

Standar audit kecurangan yang sama ini didukung oleh IIA Practice Advisories 1210.A2-1 dan 1210.A2-2, tentang identifikasi dan investigasi kecurangan. Standar praktek memberikan beberapa panduan kepada auditor internal tentang cara mendeteksi dan menyelidiki kecurangan yaitu pencegahan kecurangan terdiri dari tindakan-tindakan yang diambil untuk mencegah terjadinya kecurangan dan membatasi paparan jika kecurangan terjadi. Mekanisme utama untuk mencegah kecurangan adalah pengendalian internal. Tanggung jawab utama untuk membangun dan mempertahankan pengendalian internal ada pada manajemen.

Auditor internal bertanggung jawab untuk membantu mencegah kecurangan dengan memeriksa dan mengevaluasi kecukupan dan efektivitas sistem pengendalian internal, sepadan dengan tingkat potensi paparan risiko di berbagai segmen operasi 
perusahaan. Dalam melaksanakan tanggung jawab ini, auditor internal harus menentukan apakah:

a. Lingkungan organisasi menumbuhkan kesadaran, tujuan dan sasaran perusahaan yang realistis ditetapkan.

b. Ada kebijakan tertulis, seperti kode perilaku, yang menggambarkan kegiatan yang dilarang dan tindakan yang diperlukan setiap kali ditemukan pelanggaran.

c. Kebijakan otorisasi yang sesuai untuk transaksi ditetapkan.

d. Kebijakan, praktik, prosedur, laporan, dan mekanisme lainnya dikembangkan untuk memantau kegiatan dan melindungi aset, khususnya di bidang berisiko tinggi.

e. Saluran komunikasi memberikan informasi yang memadai dan andal kepada manajemen.

f. Rekomendasi perlu dibuat untuk pembentukan atau peningkatan pengendalian yang hemat biaya untuk membantu mencegah kecurangan.

Jika auditor internal mencurigai adanya potensi kegiatan kecurangan harus diberi tahukan kepada otoritas perusahaan yang sesuai. Atas rekomendasi dari otoritas perusahaan auditor internal bisa melakukan investigasi apa pun yang dianggap perlu dalam situasi tersebut.

IIA Practice Advisories menyatakan bahwa jika suatu perusahaan tidak memiliki kebijakan dan prosedur yang baik atau tidak memiliki kode etik, ini dapat menunjukkan lingkungan yang mendorong kecurangan. Kurangnya kode etik atau kebijakan yang tidak dirancang dengan baik seharusnya tidak menjadi alasan utama bagi auditor internal untuk mencari kegiatan kecurangan potensial. 
IIA bersama AICPA, Asosiasi Audit dan Pengendalian Sistem Informasi, ACFE, Eksekutif Keuangan Internasional, Institut Akuntan Manajemen, dan Masyarakat untuk Manajemen Sumber Daya Manusia telah berkolaborasi dan menerbitkan berbagai bahan panduan terkait kecurangan. Bidang profesional juga telah berpartisipasi dalam meninjau dan mengembangkan panduan kecurangan, termasuk American Accounting Association, Defense Industry Initiative, dan National Association of Corporate Directors. Namun, AICPA jelas mengambil peran utama di sini, dan materi panduan yang baik sekarang dikategorikan di bawah penawaran layanan forensik dan penilaian mereka (FVS). Profesional yang tertarik harus mengunjungi bagian FVS di situs web AICPA, 5 di mana mereka dapat menemukan berbagai audit untuk bahan panduan kecurangan.

Faktor-faktor risiko yang berhubungan dengan salah saji yang muncul akibat penyelewengan aset diklasifikasikan menurut tiga kondisi yang secara umum ada ketika kecurangan terjadi: (1) insentif / tekanan, (2) peluang, dan (3) sikap / rasionalisasi. Beberapa faktor risiko yang terkait dengan salah saji yang timbul dari pelaporan keuangan yang curang juga dapat muncul ketika salah saji akibat penyelewengan aset terjadi. Misalnya, ketika pemantauan manajemen dan kelemahan dalam pengendalian internal yang tidak efektif dapat terjadi salah saji karena pelaporan keuangan yang curang atau penyalahgunaan aset. Berikut ini adalah contoh faktor risiko terkait salah saji yang muncul penyalahgunaan aset. Insentif / Tekanan 
A. Kewajiban keuangan pribadi dapat menciptakan tekanan pada manajemen atau karyawan dengan akses ke uang tunai atau aset lain yang rentan terhadap pencurian untuk menyalahgunakan aset-aset tersebut.

B. Hubungan yang merugikan antara entitas dan karyawan dengan akses ke uang tunai atau aset lain yang rentan terhadap pencurian dapat memotivasi karyawan tersebut untuk menyalahgunakan aset tersebut.

\section{Peluang}

A. Karakteristik atau keadaan tertentu dapat meningkatkan kerentanan aset terhadap penyalahgunaan. Misalnya, peluang untuk menyalahgunakan aset meningkat ketika ada berikut:

1) Sejumlah besar uang tunai yang diproses

2) Barang inventaris yang berukuran kecil, bernilai tinggi, atau permintaan tinggi

3) Aset yang dapat dikonversi dengan mudah, seperti bond pembawa, berlian, atau chip komputer

4) Aset tetap yang berukuran kecil, dapat dipasarkan, atau kurang memiliki identifikasi kepemilikan yang dapat diobservasi

B. Pengendalian internal yang tidak memadai atas aset dapat meningkatkan kerentanan penyalahgunaan aset tersebut. Misalnya, penyalahgunaan aset dapat terjadi karena:

1) Pemisahan tugas atau cek independen yang tidak memadai

2) Pengawasan manajemen yang tidak memadai terhadap karyawan yang bertanggung jawab atas aset, misalnya, 
pengawasan atau pemantauan yang tidak memadai di lokasi terpencil

3) Penyaringan pelamar kerja yang tidak memadai terhadap karyawan dengan akses ke aset

4) Pencatatan yang tidak memadai sehubungan dengan aset

5) Sistem otorisasi dan persetujuan transaksi yang tidak memadai (misalnya, dalam pembelian)

6) Perlindungan fisik yang tidak memadai atas uang tunai, investasi, inventaris, atau aset tetap

7) Kurangnya rekonsiliasi aset yang lengkap dan tepat waktu

8) Kurangnya dokumentasi transaksi yang tepat waktu dan sesuai, misalnya, kredit untuk pengembalian barang dagangan

9) Kurangnya liburan wajib bagi karyawan yang melakukan fungsi pengendalian utama

10) Pemahaman manajemen teknologi informasi yang tidak memadai, yang memungkinkan karyawan teknologi informasi melakukan penyelewengan

11) Pengendalian akses yang tidak memadai atas catatan otomatis, termasuk pengendalian atas dan peninjauan log peristiwa sistem komputer

Gambar 13.2 Faktor Risiko Penipuan Terkait dengan Penyalahgunaan Aset

Sumber: American Institute of Certified Public Accountants. 


\section{E. Investigasi Kecurangan Oleh Auditor Internal}

Selain membantu membangun dan meninjau pengendalian untuk mencegah dan mendeteksi kecurangan, auditor internal terkadang menjadi sangat terlibat dalam investigasi kecurangan. Auditor internal dapat membantu mengumpulkan informasi untuk penemuan yang lebih kecil atau menyediakan bahan pendukung untuk masalah yang lebih besar. Audit internal sering terlibat dalam hal-hal yang berpotensi terkait dengan kecurangan karena beberapa informasi bermasalah yang ditemui selama audit.

Ketika dihadapkan dengan informasi kecurangan potensial, langkah pertama audit internal harus selalu berkonsultasi dengan penasihat perusahaan. Karena sifat dugaan serta luasnya informasi awal, masalah tersebut juga dapat diserahkan kepada otoritas hukum. Dalam hal-hal yang lebih kecil audit internal terkadang akan diminta sebagai penanggungjawab atas penyelidikan. Dalam banyak kasus, jenis investigasi ini hanya melibatkan tinjauan dokumen secara terperinci. Bukti yang dikumpulkan dari tinjauan dokumen itu akan menjadi dasar untuk tindakan lebih lanjut.

Investigasi terkait kecurangan memerlukan auditor internal untuk beroperasi agak berbeda daripada selama audit internal keuangan atau operasional normal. Dalam ulasan terkait kecurangan, auditor internal harus memiliki tiga tujuan utama:

a. Buktikan kerugiannya. Tinjauan terkait kecurangan biasanya dimulai dengan temuan bahwa seseorang mencuri sesuatu atau melakukan sesuatu yang melanggar aturan yang berlaku. Tinjauan investigasi yang dipimpin oleh audit internal harus mengumpulkan bahan yang relevan sebanyak yang diperlukan 
untuk menentukan ukuran dan cakupan kerugian secara keseluruhan.

b. Tetapkan tanggung jawab dan niat. Ini adalah langkah "Siapa yang melakukannya?". Sebisa mungkin, tim audit harus berusaha mengidentifikasi semua orang yang bertanggung jawab atas masalah ini dan apakah ada maksud khusus atau berbeda yang terkait dengan tindakan kecurangan.

c. Buktikan metode investigasi audit yang digunakan. Tim investigasi perlu dapat membuktikan bahwa kesimpulan terkait kecurangan mereka didasarkan pada proses investigasi langkah demi langkah yang terperinci, bukan hanya perburuan penyihir yang tidak terkoordinasi. Tinjauan tersebut harus didokumentasikan menggunakan proses tinjauan audit internal terbaik. Yang sangat penting di sini adalah semua dokumen yang akan digunakan diamankan.

Ada banyak prosedur lain yang terkait dengan pemeriksaan terkait kecurangan. Tujuan bab ini bukan untuk menggambarkan keseluruhan proses pemeriksaan kecurangan tetapi untuk membahas peningkatan penekanan pada deteksi dan pencegahan kecurangan sebagaimana diuraikan oleh standar yang lebih baru, terutama pedoman AICPA serta publikasi manajemen kecurangan IIA yang sebelumnya dirujuk. Auditor internal yang tertarik untuk mempelajari lebih lanjut tentang investigasi kecurangan harus mengeksplorasi kegiatan dan publikasi dari Asosiasi Penguji Kecurangan Bersertifikat.

\section{F. Proses Pencegahan Penipuan Teknologi Informasi}

Teknologi informasi atau kecurangan terkait teknologi mencakup berbagai masalah dan kekhawatiran. Dalam lingkungan bisnis saat 
ini, sistem $\mathrm{TI}$ hampir selalu merupakan komponen kunci dari kecurangan keuangan atau akuntansi modern yang terkait. Karena sistem dan proses TI mendukung begitu banyak bidang dan melintasi begitu banyak lini dalam perusahaan, kita dapat memikirkan kecurangan terkait $\mathrm{TI}$ dalam berbagai dimensi mulai dari yang kecil hingga kegiatan kecurangan yang signifikan:

a. Masalah akses Internet. Perusahaan sering membuat pedoman dan kadang-kadang pengendalian untuk membatasi penggunaan Internet, tetapi Web begitu meresap sehingga sulit untuk memisahkan penggunaan pribadi dari penggunaan bisnis. Sekali lagi, aturan seperti itu sering diabaikan oleh karyawan dan kadang-kadang dilewati oleh perangkat lunak yang memungkinkan mereka untuk mengatasi hambatan firewall dalam sistem. Ada kemungkinan penyalahgunaan yang jauh lebih besar di sini, tetapi perusahaan berpotensi dapat memantau penggunaan Internet karyawan melalui alat pemantauan perangkat lunak.

b. Penggunaan sumber daya TI secara pribadi dan tidak benar. Suatu perusahaan harus menekankan kepada karyawan bahwa mereka tidak boleh melakukan bisnis pribadi saat berada di tempat kerja. Mungkin bahkan lebih besar daripada risiko kecurangan di sini adalah kemungkinan memperkenalkan virus atau perangkat lunak berbahaya lainnya ke sistem perusahaan.

c. Penggunaan perangkat lunak secara ilegal. Karyawan kadangkadang akan berusaha mencuri atau mengunduh salinan perangkat lunak perusahaan atau akan menginstal perangkat lunak mereka sendiri pada sumber daya komputer perusahaan. Dengan melakukan hal itu mereka melanggar aturan 
perusahaan dan seringkali menempatkan majikan mereka dalam pelanggaran perjanjian lisensi perangkat lunak.

d. Masalah keamanan komputer dan kecurangan kerahasiaan. Karyawan dapat melanggar perlindungan kata sandi dan mendapatkan akses yang tidak patut ke sistem dan fles TI.

e. Pencurian informasi melalui perangkat USB. Suatu perusahaan dapat menghadapi risiko signifikan dari pencurian atau kehilangan data seperti catatan pelanggan melalui perangkat penyimpanan sederhana ini. Pencurian informasi atau kecurangan komputer penyalahgunaan data lainnya. Mengakses sistem komputer dengan cara yang tidak semestinya adalah dengan melanggar pengendalian kata sandi, dan hal lain untuk melihat, memodifikasi, atau menyalin data atau brosur dengan tidak benar. Ini bisa menjadi penyebab signifikan kejahatan komputer.

f. Penggelapan atau transfer dana elektronik yang tidak sah. Mencuri uang atau sumber daya lainnya melalui transaksi yang tidak patut atau tidak sah mungkin merupakan penyebab paling signifikan dari sistem TI dan masalah kecurangan jaringan.

Jika seorang karyawan diberikan laptop untuk bekerja dan diberitahu bahwa itu hanya untuk penggunaan bisnis, namun karyawan tersebut menggunakan laptop yang sama untuk menulis laporan buku sebagai bagian dari pekerjaan rumah anaknya, apakah ini merupakan kejahatan komputer atau kecurangan? Jawabannya di sini benar-benar ya, sesuai aturan yang ditetapkan. Jika perusahaan telah menetapkan aturan, itu dilakukan untuk alasan yang baik, dan karyawan tidak boleh melanggarnya. Namun, haruskah audit internal meluncurkan ulasan untuk menemukan pelanggaran di bidang ini? 
Mungkin tidak; ada daerah berisiko tinggi yang lebih penting untuk menghabiskan waktu dan sumber daya yang terbatas.

Bahwa ada banyak kemungkinan kecurangan dan penyalahgunaan komputer. Ini sering merupakan bidang yang sangat kompleks di mana keterampilan teknis yang kuat diperlukan untuk memahami alat dan metode. Ini adalah area di mana aturan terus berubah. Individu dengan niat curang mencari cara baru untuk melanggar pengendalian otomatis yang sudah ada, dan auditor yang terampil menemukan cara untuk mendeteksi dan melindungi aktivitas kecurangan ini.

Area deteksi kecurangan sistem TI terkait adalah forensik komputer, pemeriksaan terperinci komputer dan perangkat periferalnya menggunakan teknik investigasi dan analisis komputer untuk menemukan atau menentukan bukti hukum potensial dalam situasi kecurangan. Idenya di sini adalah bahwa pada dasarnya segala sesuatu yang ditulis pada komputer dapat dipulihkan, bahkan jika itu telah dihapus melalui perintah sistem operasi.

Data sistem $\mathrm{TI}$ yang dipulihkan seringkali dapat menjadi tambang emas dalam penyelidikan kecurangan. Pelaku mungkin merasa bahwa mereka telah menutupi jejak mereka dengan menghapusnya, tetapi alat forensik komputer sering memungkinkan pemulihan penuh. Pemeriksaan forensik melibatkan pemeriksaan media komputer, seperti CD-ROM, hard disk drive, cadangan fles, dan media lain yang digunakan untuk menyimpan data. Spesialis forensik menggunakan perangkat lunak khusus untuk menemukan data yang berada di sistem komputer, atau dapat memulihkan informasi file dan kata sandi yang dihapus/dienkripsi, atau rusak, sehingga dokumen dapat dibaca. Auditor internal mungkin tidak memiliki 
keterampilan untuk melakukan analisis seperti itu tanpa bantuan yang diperlukan.

Selain dari kesaksian langsung oleh seorang saksi mata, bukti dokumenter biasanya merupakan bentuk bukti yang paling meyakinkan, dan jejak kertas secara tradisional telah bermanfaat bagi penyelidik kecurangan TI. Dalam beberapa tahun terakhir, bukti dokumenter terbatas pada kertas. Di mana aturan bukti terbaik diterapkan, dokumen asli dibuat. Namun, dokumen jarang diketik menggunakan mesin tik atau bahkan dicetak hari ini dan biasanya diproduksi pada pengolah kata komputer pribadi. Beberapa dari dokumen-dokumen ini tidak lagi dicetak dan dikirimkan melalui email atau faks ke penerima secara langsung dari komputer. Karena perubahan dalam cara informasi didistribusikan dan cara orang berkomunikasi, salinan file komputer sekarang sebagus dokumen elektronik asli.

\section{G. Deteksi Fraud Auditor Internal}

Kecurangan selalu bersama kita, tidak peduli seberapa baik kita membangun standar kejujuran yang kuat, melalui kode etik dan sejenisnya, serta membangun pengendalian yang lebih kuat untuk mencegah kecurangan. Terburuk oleh skandal akuntansi yang menyebabkan SOx, AICPA dan auditor eksternal telah mengambil tugas utama untuk mendeteksi dengan lebih baik kegiatan kecurangan dalam audit laporan keuangan mereka. Waktu akan menunjukkan seberapa efektif standar baru dan bahan panduan, tetapi mereka membutuhkan dimensi pemikiran baru ketika merencanakan dan melakukan laporan keuangan serta semua tingkatan audit. 
Auditor internal perlu memberikan pertimbangan yang lebih besar terhadap kecurangan dalam pekerjaan audit mereka. Mereka selalu terlibat dalam beberapa tingkat penyelidikan kecurangan ketika dipanggil oleh manajemen, tetapi pertimbangan kecurangan dan pertimbangan pencegahan perlu menjadi komponen yang lebih signifikan dari setiap audit internal. Auditor internal mungkin perlu memasuki perikatan audit internal baru dengan mengajukan beberapa pertanyaan kepada diri sendiri tentang di mana auditee baru melakukan tindakan curang. Auditor internal harus mempertahankan tingkat skeptis tentang potensi kecurangan dalam penugasan pekerjaan yang sedang berlangsung.

Auditor internal harus memiliki tingkat pemahaman umum tentang redflag yang menunjukkan kemungkinan kecurangan serta prosedur peninjauan audit internal umum yang mencakup investigasi untuk kecurangan dalam semua audit internal. Namun, auditor internal sebaiknya tidak memulai audit internal baru yang khas dengan harapan bahwa pihak yang diaudit entah bagaimana curang atau tidak jujur. Sebaliknya, mereka harus memahami bahwa kecurangan dapat terjadi di berbagai tingkatan, dan di mana ada kecurigaan dalam proses peninjauan, mereka harus memiliki pengetahuan untuk melaporkan masalah tersebut kepada pihak berwenang yang tepat dan untuk membantu dalam penyelidikan kecurangan yang diminta.

\section{H. Simpulan}

Kecurangan berdampak sangat mahal untuk perusahaan apa pun yang menjadi korban, dan pengendalian internal yang efektif adalah garis pertahanan pertama perusahaan terhadap kecurangan. Ketika seorang auditor internal melihat bukti dari satu atau lebih red flags 
mungkin sudah waktunya untuk menggali sedikit lebih dalam untuk mengidentifkasi kecurangan.

Deteksi kecurangan jauh lebih sulit ketika ada kolusi antara banyak orang. Setiap kali banyak orang terlibat dalam kecurangan yang sama, ada kemungkinan seseorang akan mematahkannya. Sementara kecurangan besar yang melibatkan partisipasi manajemen senior sulit untuk dideteksi.

Auditor internal bertanggung jawab untuk membantu mencegah kecurangan dengan memeriksa dan mengevaluasi kecukupan dan efektivitas sistem pengendalian internal.

\section{Contoh Kasus Deteksi Fraud Auditor Internal}

Risiko yang dihadapi perusahaan diantaranya adalah Integrity risk, yaitu resiko adanya kecurangan oleh manajemen atau pegawai perusahaan, tindakan illegal,atau tindak penyimpangan lainnya yang dapat mengurangi nama baik perusahaan dan mengurangi kemampuan perusahaan dalam mempertahankan kelangsungan hidupnya. Adanya resiko tersebut mengharuskan internal auditor untuk mendeteksi terjadinya kecurangan.

\section{Solusi}

Berdasarkan penggolongan kecurangan antara lain

Kecurangan Laporan Keuangan (Financial Statement Fraud). Kecurangan dalam penyajian laporan keuangan umumnya dapat dideteksi melalui analisis laporan keuangan sebagai berikut:

a. analisis vertikal. Sebagai contoh, adanya kenaikan persentase hutang niaga dengan total hutang dari rata-rata $28 \%$ menjadi $52 \%$ dilain pihak adanya penurunan persentase biaya penjualan dengan total penjualan. 
b. analisis horizontal, Sebagai contoh adanya kenaikan penjualan sebesar $80 \%$ sedangkan harga pokok mengalami kenaikan $140 \%$. Dengan asumsi tidak ada perubahan lainnya dalam unsur-unsur penjualan dan pembelian, maka hal ini dapat menimbulkan sangkaan adanya pembelian fiktif, penggelapan, atau transaksi illegal lainnya.

c. analisis rasio, contoh adalah current ratio, adanya penggelapan uang atau pencurian kas dapat menyebabkan turunnya perhitungan rasio tersebut.

\section{Pertanyaan untuk didiskusikan}

1. Jelaskan tanda-tanda awal (symptoms) biasanya muncul dalam kasus kecurangan menurut www.aicpa.org.

2. Jelaskan mengapa orang melakukan kecurangan berdasarkan teori fraud diamond!

\section{Soal Kasus Investigasi Kecurangan}

Pada perusahaan terjadi collusion antara bagian pembelian, bagian gudang, bagian keuangan, dan supplier dalam pembelian bahan baku produksi atau barang lainnya. PT X memesan 1.000 unit barang A kualitas premium dari pemasok Y dengan harga Rp. 100.000 per unit.Dari transaksi tersebut, ada 2 kemungkinan yang terjadi, yaitu:

Kemungkinan 1:

Barang yang dikirim 1.000 unit barang A kualitas standar dengan harga yang seharusnya di bawah premium yaitu $\mathrm{Rp} 95.000$. Bagian gudang PT $X$ akan membuat laporan penerimaan barang yang menyebutkan menerima 1000 unit barang A dengan kualitas premium. Supplier $\mathrm{Y}$ akan tetap menagih dan dibayar sebesar Rp 100.000.000 
Kemungkinan 2:

Supplir Y mengirim 900 unit barang A kualitas premium. Tapi bagian gudang PT $X$ akan membuat laporan penerimaan barang sebanyak 1.000 unit barang A kualitas premium. Serta menagih dan dibayar Rp 100.000.000. Selisih Rp 10.000.000 akan dibagi-bagi diantara mereka. Cara yang kedua lebih sulit terdeteksi jika jenis barang PT X sangat banyak dan pencatatan persediaan menggunakan physical system Bagaimana cara auditor internal melakukan investigasi kecurangan tersebut diatas?

Daftar Pustaka

American Institute of Certified Public Accountants. Faktor Risiko Penipuan Terkait dengan Penyalahgunaan Aset 2017.

IIARF. (2009). Internal Audit Capability Model (IA-CM): For the Public sector, 2009.

Moeller, R. R. (2016). Brink's Modern Internal Auditing Eighth Edition A Common Body of Knowledge Published by John Wiley \& Sons, Inc., Hoboken, New Jersey. 


\section{DAFTAR PUSTAKA}

AICPA. (2015). Audit Analytics Audit Analytics.

AICPA. (2016). The American Institute of Certified Public Accountants (AICPA). About the AICPA dapat diunduh www.aicpa.org '.

Anderson, D. (2016). Relationships and Risk Insights from Stakeholders in North America.

Asosiasi Auditor Intern Pemerintah Indonesia. (2010). Pedoman Perencanaan Audit Berbasis Risiko Auditor Intern Pemerintah Indonesia.

Asosiasi Auditor Intern Pemerintah Indonesia. (2018). Pedoman

Perencanaan Audit Berbasis Risiko Auditor Intern Pemerintah Indonesia.

Audit Universe. (2018). Copy of Audit Universe and Risk Assessment Tool.

Auditor Internal. (2019). Audit universeAuditors. (October), 1-6. Auditors, I. (2017). Standar internasional praktik profesional audit internal (standar).

Barr-pulliam, D. (2016). Engaging Third Parties for Internal Audit Activities.

BDO. (2015). Establishing An Effective Internal Audit Function. (October).

COSO. (2017a). Enterprise Risk Management Applying enterprise risk management to environmental , social and governancerelated risks.

COSO. (2017b). Enterprise Risk Management Framework: Integrating with Strategy and Performance COSO's Fundamental Principle. 1-32.

coso Internal Control. (2013). Integrated Framework Principles. 
2013.

Deloach, J., \& Hjelm, C. L. (2016). Six Audit Committee Imperatives Enabling Internal Audit to Make a Difference.

Fraud Examiner Manual. (2012). Pengumpulan dan evaluasi bukti. Gultom, J. (2018). Agility Dapat diunduh https://jonnygultom.wordpress.com /2018/07/28/agility/. Gultom, J. (2019a). Fraud Risk Assessement. Dapat diunduh pada https://jonnygultom.wordpress.com/2019/08/11/fraudrisk-assessment/.

Gultom, J. (2019b). Risk Culture. Dapat diunduh https://jonnygultom. wordpress.com /2019/10/20/riskculture/.

Hardiwinoto. (2014). Bukti Audit. Dapat diunduh pada http://hardiwinoto.com/bukti-audit/.

Henning Kagermann, at all. (2008). Internal Audit Handbook. Springer-Verlag Berlin Heidelberg.

Http://mercubuana.ac.id. (2018). Sejarah, perkembangan dan gambaran umum "IA" dapat diunduh pada http://mercubuana.ac.id/files/

AuditInternall/AUDIT\%20INTERNAL\%20TM\%201-ok.pdf. http://yukbelajaraudit.blogspot.com/. (2014). SAMPLING AUDIT.

Retrieved from http://yukbelajaraudit.blogspot.com/2014/08/samplingaudit.html

https://jonnygultom.wordpress.com. (2016). https://jonnygultom.wordpress.com/2016/03/19/failures/. https://jonnygultom.wordpress.com. (2019).

https://jonnygultom.wordpress.com/2019/10/20/riskculture/. 
https://na.theiia.org. (2018). https://na.theiia.org/standardsguidance/recommended-guidance/practice-guides/Pages/ Engagement-Planning-Assessing-Fraud-Risks.aspx.

IIA. (2018). Internal Audit Competencies. Retrieved from https://iia.no/wp-content/uploads/2018/06/2018-GlobalKB-Internal-Audit-Competencies.pdf

IIARF. (2009). Internal Audit Capability Model (IA-CM): For the Public sector, 2009.

Jusup, A. H. (2001). Sampling Audit dalam Konsep Dasar. 1-33.

Kagermann, H. (2008). Internal Audit Handbook. Springer-Verlag Berlin Heidelberg.

Kinney, W., Weber, C., Busch, J., \& Eckes, P. (2008). Internal Audit Handbook.

Loughlin, C. J. O. (2016). Internal Audit Quality Assurance and Improvement $A$ Call to Action.

Moeller, R. R. (2007). COSO Enterprise Risk Management: Understanding the New Integrated ERM Framework. Copyright (C) 2007 John Wiley \& Sons. Reprinted with the permission of John Wiley \& Sons.

Moeller.R.R. R. R. (2016). Brink's Modern Internal Auditing Eighth Edition A Common Body of Knowledge Published by John Wiley \& Sons, Inc., Hoboken, New Jersey.

Rittenberg, L. E. (2015a). Ethics and Pressure.

Rittenberg, L. E. (2015b). Ethics and Pressure, The IIA Research Foundations.

Rittenberg, L. E. (2015c). Interacting with Audit Committees The Way Forward for Internal Audit.

Rose, J. (2015). The Top 7 Skills AUDITOR KEPALAs Want Building the Right Mix of Talent for Your Organization. 
Sarbanes. (2002). Sarbanes-Oxley Act of 2002. Corporate responsibility.

Sarbanes. (2010a). Amendments to the Act. made by the DoddFrank Wall Street Reform and Consumer Protection Act (July 21, 2010).

Sarbanes. (2010b). Sarbanes-Oxley Act (SOx) Bagian 404.

Stafford, V. H., \& Thor, M. (2016). Achieving Excellence in Assurance, Strategic Risk Insights, and More Viewpoints From Financial Services Stakeholders.

The Institute of Auditor internal . (2017). Piagam Audit Internal, dapat diunduh pada na.theiia.org , translations, PP-TheInternal-Audit-Charter-Indonesian.

The Institute of Auditor internal s. (2016). Standar Internasional Untuk Praktek Profesional Auditing Internal.

Tsintzas, E. (2016). Lifelong Learning for Auditor internal s.

Bailey, J. A. (2015). Looking to the Future for Internal Audit Standards.

Witzany, A. (2016). Voice of the Customer Stakeholders 'Messages for Internal Audit.

www.bca.co.id. (2018). www.bca.co.id, tentang-bca , old-tatakelola-perusahaan > media. 


\section{BIODATA PENULIS}

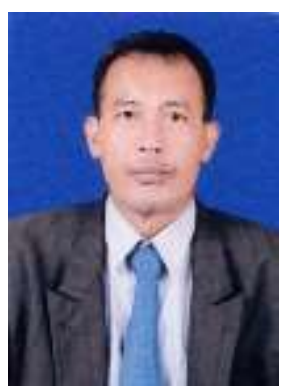

Drs. Nurasik..MM lahir di Sidoarjo, 20 Agustus 1960. Menyelesaikan Studi Strata 2 (S2) pada Universitas Muhammadiyah Malang. Aktif melakukan penelitian dan penulisan karya ilmiah baik berupa buku ajar, jurnal ilmiah, dan artikel popular.

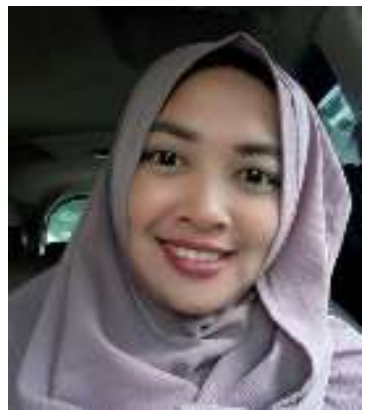

Santi Rahma Dewi, SE., M.Ak lahir di Magetan, 20 Juli 1980. Menyelesaikan Studi 2 (S2) Pada UPN Veteran Surabaya. Aktif melakukan penelitian dan penulisan karya ilmiah baik berupa buku ajar, jurnal ilmiah, dan artikel popular. 
1ร8N 978-623-6833-56-8 (ตำ)

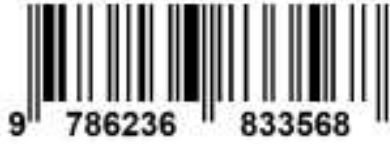

